ORNL/SPR-2019/1089

\title{
Technical Gap Assessment for Materials and Component Integrity Issues for Molten Salt Reactors
}

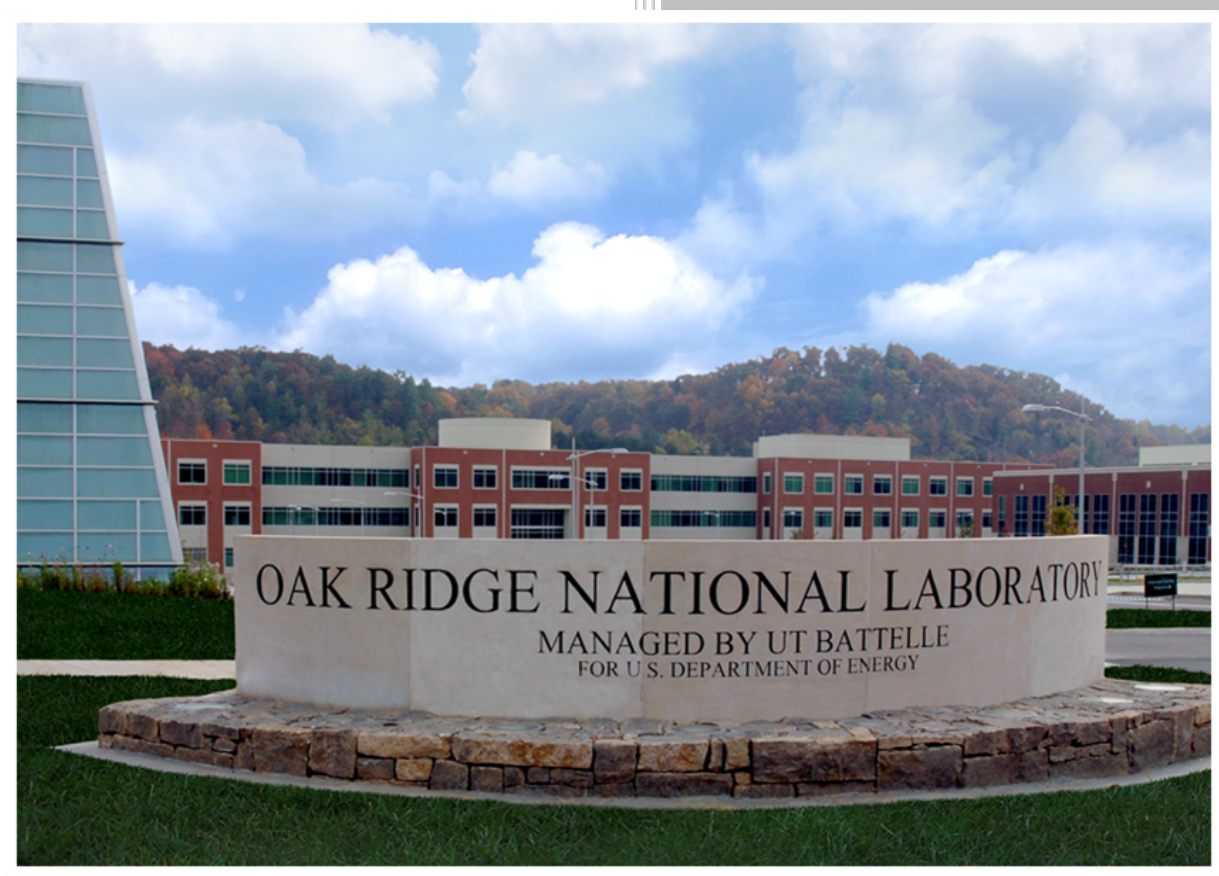

J. Busby

L. Garrison

L. Lin

S. Raiman

S. Sham

C. Silva

H. Wang

March 2019 
This report was prepared as an account of work sponsored by an agency of the United States Government. Neither the United States Government nor any agency thereof, nor any of their employees, makes any warranty, express or implied, or assumes any legal liability or responsibility for the accuracy, completeness, or usefulness of any information, apparatus, product, or process disclosed, or represents that its use would not infringe privately owned rights. Reference herein to any specific commercial product, process, or service by trade name, trademark, manufacturer, or otherwise, does not necessarily constitute or imply its endorsement, recommendation, or favoring by the United States Government or any agency thereof. The views and opinions of authors expressed herein do not necessarily state or reflect those of the United States Government or any agency thereof. 


\section{TECHNICAL GAP ASSESSMENT FOR MATERIALS AND COMPONENT INTEGRITY ISSUES FOR MOLTEN SALT REACTORS}
J. Busby ${ }^{1}$
L. Garrison ${ }^{1}$
L. Lin $^{1}$
S. Raiman ${ }^{1}$
S. Sham ${ }^{2}$
C. Silva ${ }^{1}$
H. Wang ${ }^{1}$
R. lyengar ${ }^{3}$
G. Tartal ${ }^{3}$

${ }^{1}$ Oak Ridge National Laboratory

${ }^{2}$ Argonne National Laboratory

${ }^{3}$ NRC Project Manager

March 2019

Prepared by

OAK RIDGE NATIONAL LABORATORY

Oak Ridge, TN 37831-6283

managed by

UT-BATTELLE, LLC 



\section{TABLE OF CONTENTS}

LIST OF FIGURES

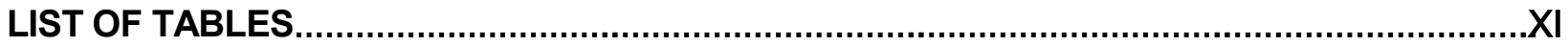

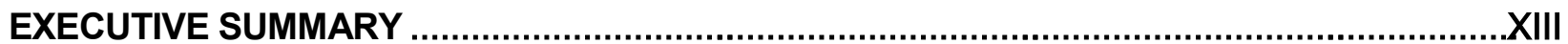

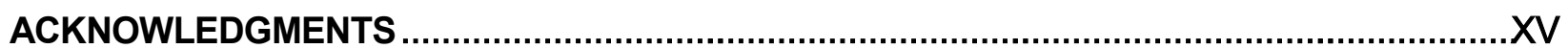

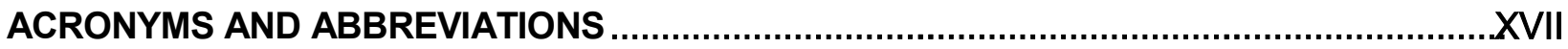

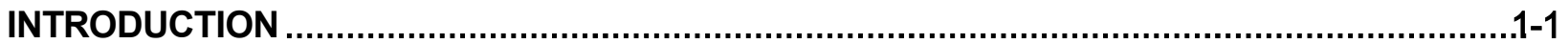

1 MECHANICAL PROPERTIES....................................................................................

1.1 Rationale for Selecting the Materials .................................................................... $1-2$

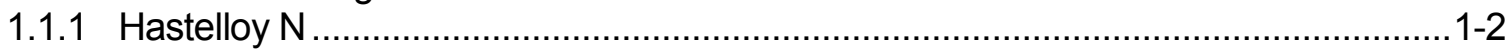

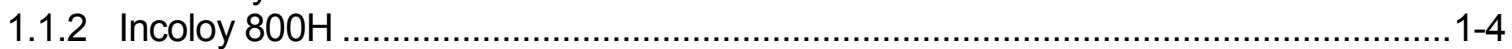

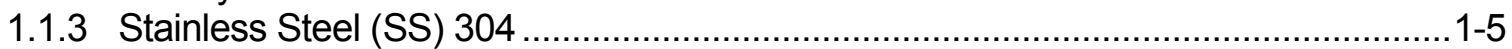

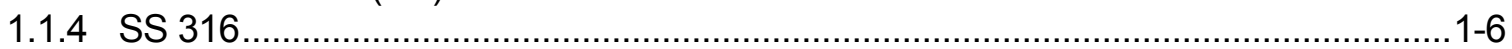

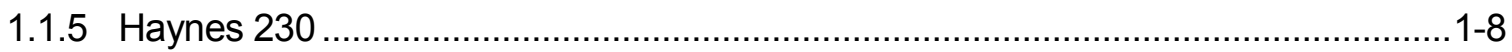

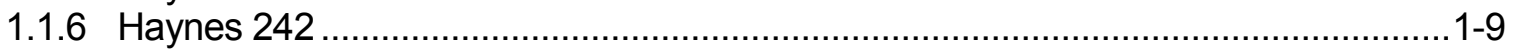

1.2 Code Qualification .................................................................................................. 1 10

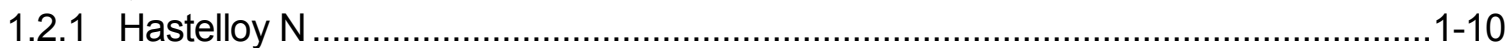

1.2.2 Incoloy $800 \mathrm{H}$, SSs 304, 316, Haynes 230, and Haynes 242 ..............................1-12

1.2.3 Summary and suggestions ……………………....................................1-17

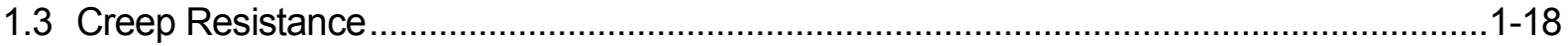

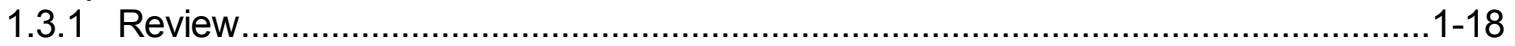

1.3.2 Rupture and minimum creep rate ...............................................................1-21

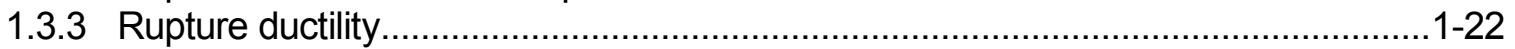

1.3.4 Comparison of rupture data in molten salt with those in air .................................1-22

1.3.5 Comparison of Hastelloy $\mathrm{N}$ with other candidates ............................................1-23

1.4 Time-Independent Properties, Fatigue, and Aging Effects ..........................................1-25

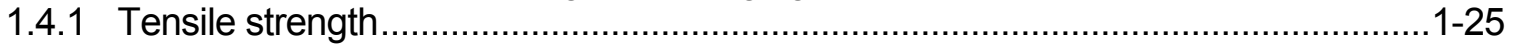

1.4.2 Stress- and strain-controlled fatigue ............................................................1-27

1.4.3 Relaxation behavior …….......................................................................1-32

1.4.4 Effect of service life on short-time properties....................................................1-34

1.5 Joints, Weldments, and Fabrication-Related Material Issues …………………..............1-36

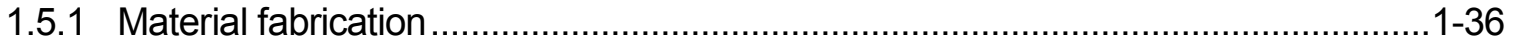

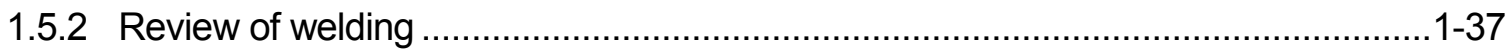

1.5.3 Time-independent properties of welds ........................................................1-37

1.5.4 Creep rupture and MCR of welds .................................................................1-39

1.5.5 Recent developments in welding ...............................................................1-42

1.5.6 Joining for reactor components .................................................................1-43

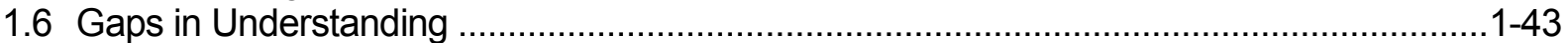

1.6.1 Advanced alloys for MSR ………………….........................................1-43

1.6.2 Cladding or lining......................................................................................

1.6.3 Database for Hastelloy N .........................................................................1-46

1.6.4 Lifetime prediction ................................................................................

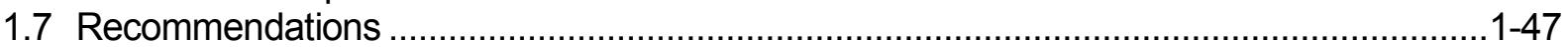

1.7.1 Inclusion of Hastelloy N into Section III-5 for construction of Class B components 1-47

1.7.2 Codification of advanced alloys for MSRs .......................................................1-48

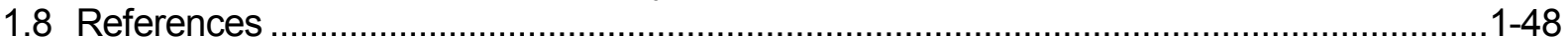




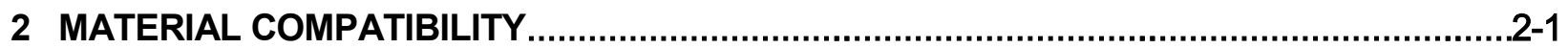

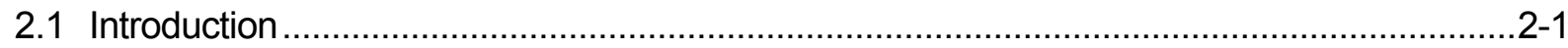

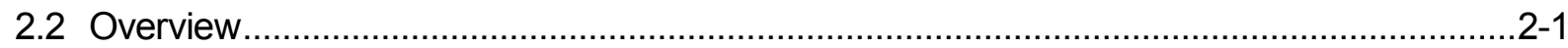

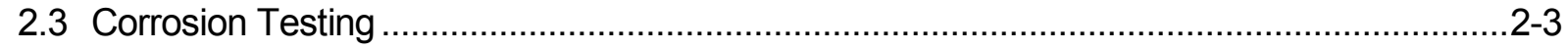

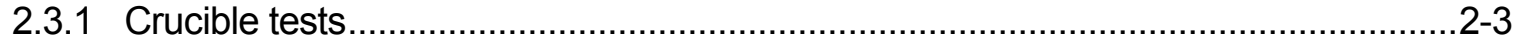

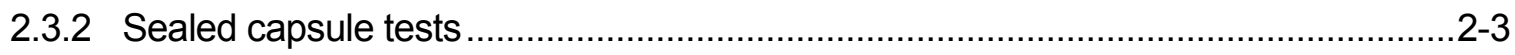

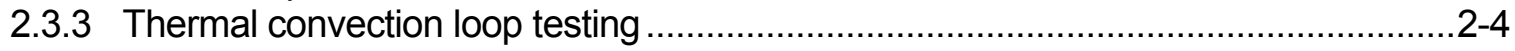

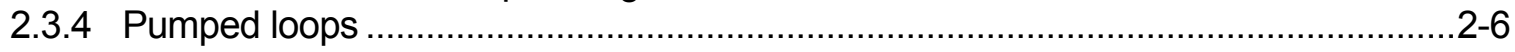

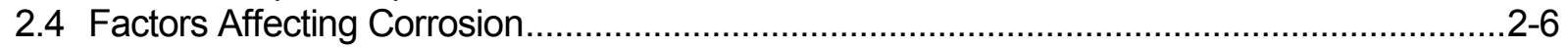

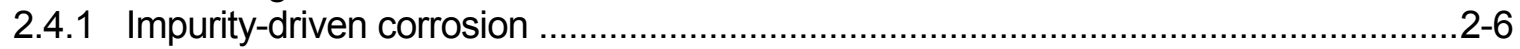

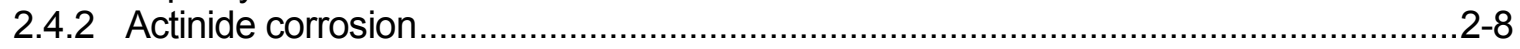

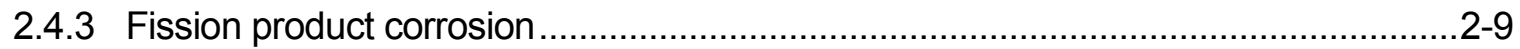

2.4.4 Irradiation and corrosion .......................................................................... 2-10

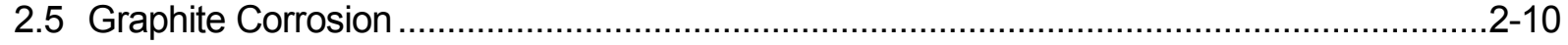

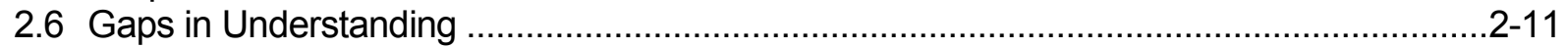

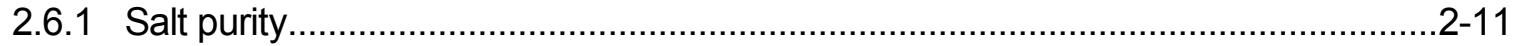

2.6.2 Fission product corrosion .........................................................................2-11

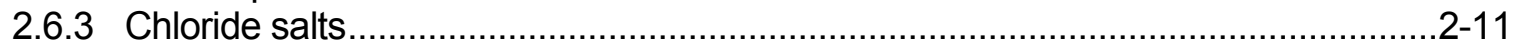

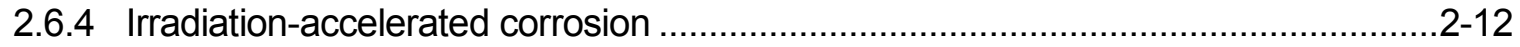

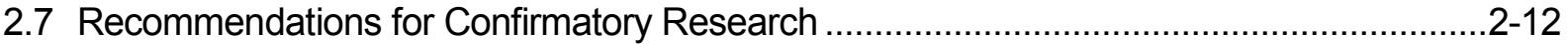

2.7.1 Systematic experimental data..................................................................... $2-12$

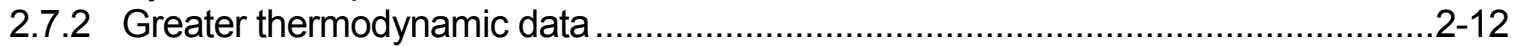

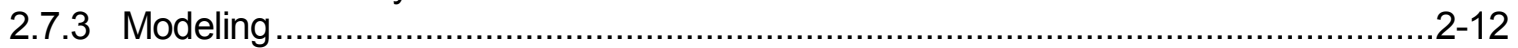

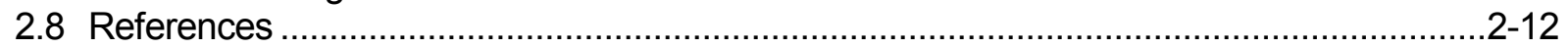

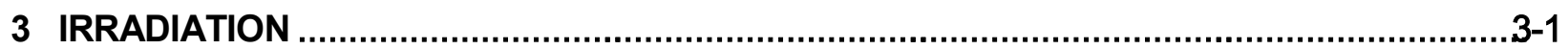

3.1 Hastelloy $\mathrm{N}$ and Modified Hastelloy $\mathrm{N}$.....................................................................

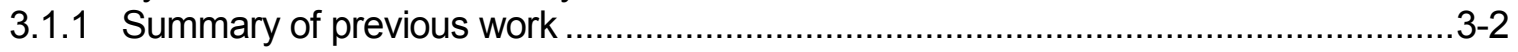

3.1.2 Concluding remarks and gap analysis ............................................................

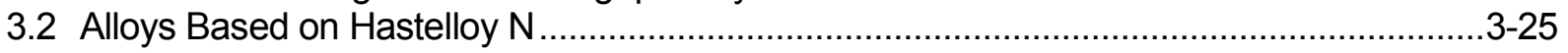

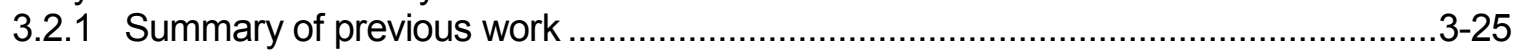

3.2.2 Concluding remarks and gap analysis ………….............................................

3.3 Other Nickel-based Alloys ...........................................................................................

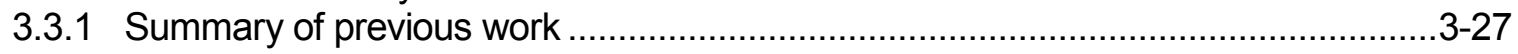

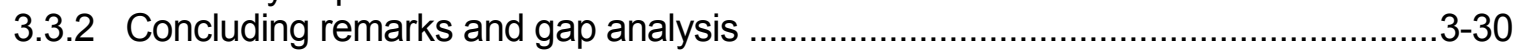

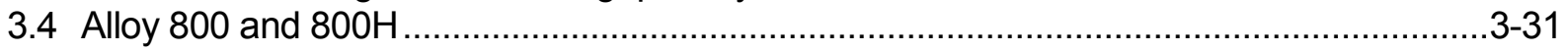

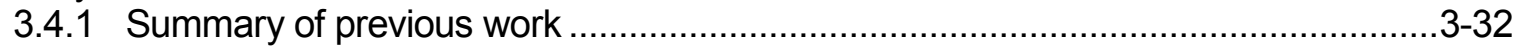

3.4.2 Concluding remarks and gap analysis ……………........................................ $3-33$

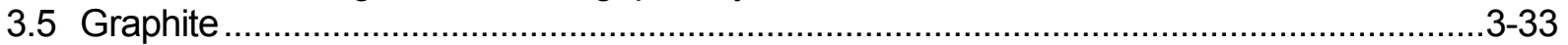

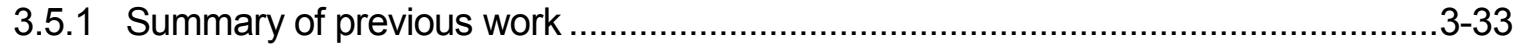

3.5.2 Concluding remarks and gap analysis .............................................................3-36

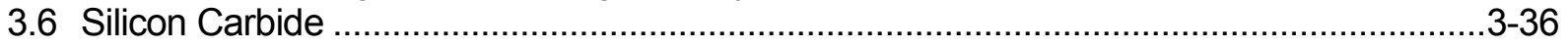

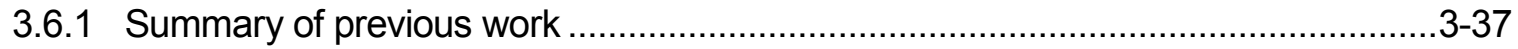

3.6.2 Concluding remarks and gap analysis …….................................................. $3-40$

3.7 Common Issues for All Materials …………………..............................................

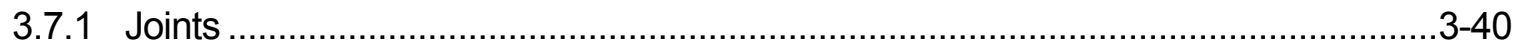

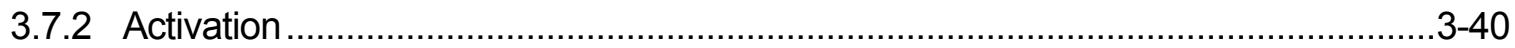

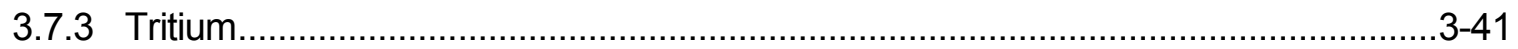

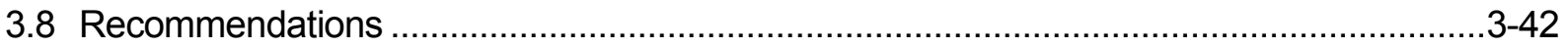

3.8.1 Recommendations for Hastelloy $\mathrm{N}$ and alloys based on Hastelloy N......................-42

3.8.2 Recommendations for other Nickel-based alloys and Alloy $800 / 800 \mathrm{H} . . . \ldots \ldots \ldots \ldots \ldots . . . . .3-42$ 


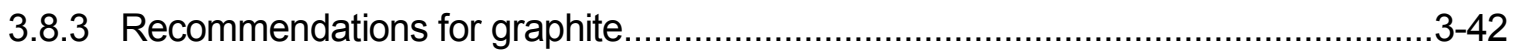

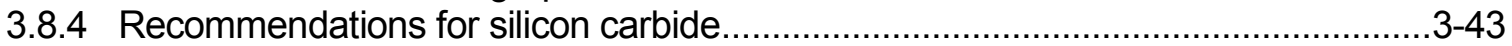

3.8.5 Recommendations for all materials ........................................................... $3-43$

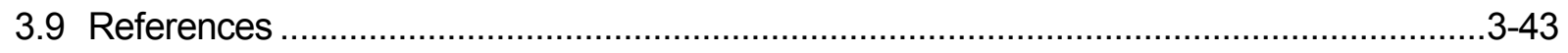

4 ASME CODE QUALIFICATION, SECTION III DIVISION 5 ...........................................4-1

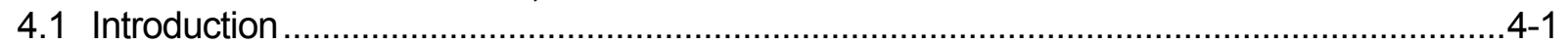

4.2 Subsection HB, Subpart B — Metallic Components ................................................... $4-2$

4.3 Currently Qualified Class A Materials ........................................................................ $4-7$

4.4 Development of New Advanced Materials................................................................. $4-8$

4.5 In Situ, Passive Materials Surveillance Program for MSRs .............................................4-11

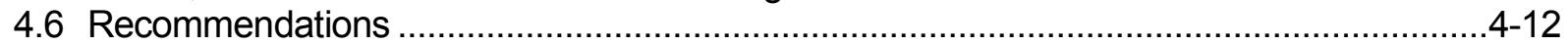

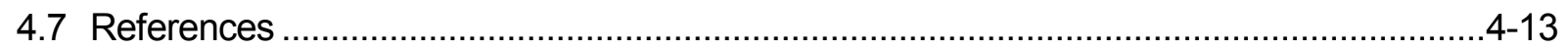

5 SYNERGIES WITH OTHER PROGRAMS ...................................................................

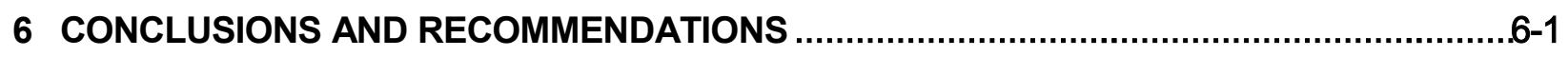

APPENDIX A — ADVANCED HIGH-TEMPERATURE REACTOR ....................................A-1

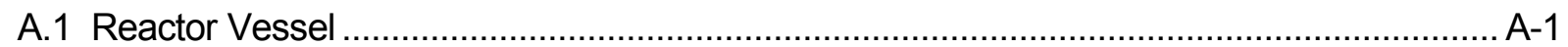

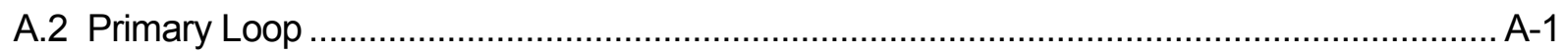

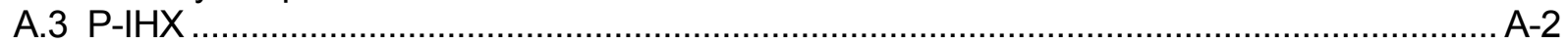

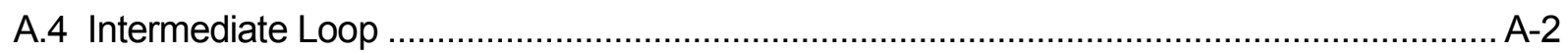

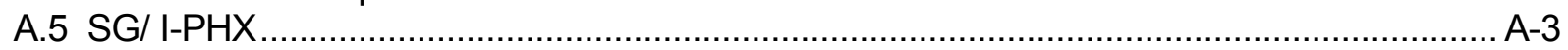

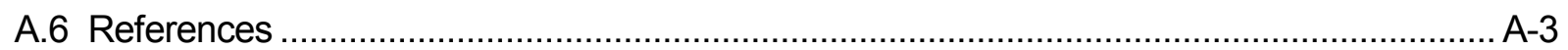





\section{LIST OF FIGURES}

Figure 1 Comparison of the allowable stresses (S) based on 100,000 $\mathrm{h}$ for candidate

materials considered for service at temperature up to $900^{\circ} \mathrm{C}$............................. 1-11

Figure 2 Comparison of the stress intensity $\left(S_{m}\right)$ values for candidate materials

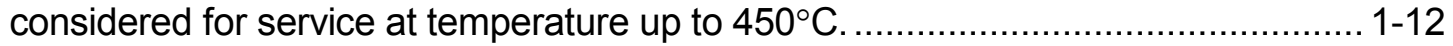

Figure 3 Molten salt data plotted over isothermal curves based on the fit to the air data...... 1-23

Figure 4 Creep-rupture stresses of Hastelloy $\mathrm{N}$ at 593,704 , and $816^{\circ} \mathrm{C}(1100,1300$, and $1500^{\circ} \mathrm{F}$ ) compared with those of Incoloy $800 \mathrm{H}$, SS 316, and Haynes 230....... 1-24

Figure 5 Comparison of yield strength data with the $S_{y} R_{y}$ curve for Hastelloy $N$................. 1-26

Figure 6 Comparison of ultimate tensile strength data with the $S_{T} R_{T}$ curve for

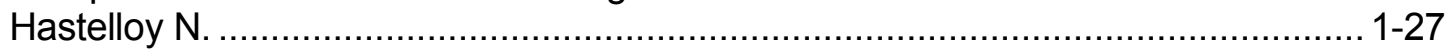

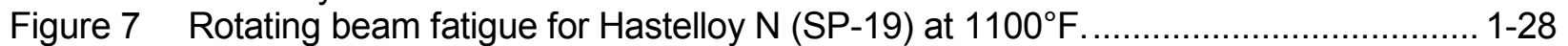

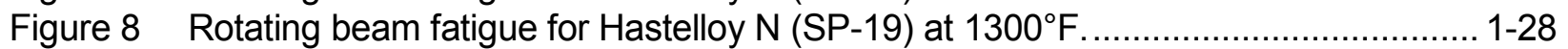

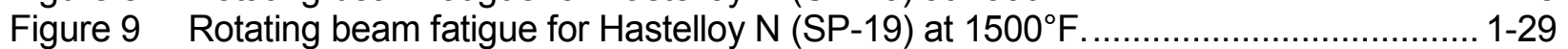

Figure 10 Plastic strain range versus cyclic life for Hastelloy N........................................ 1-29

Figure 11 Design fatigue curves, $S_{a}$, for Hastelloy $N$ produced by Briggs in 1969................. 1-30

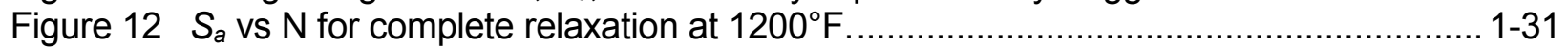

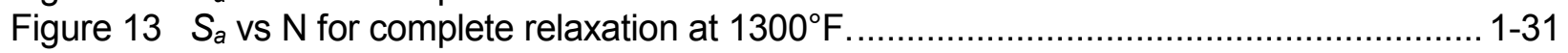

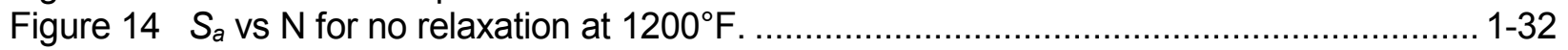

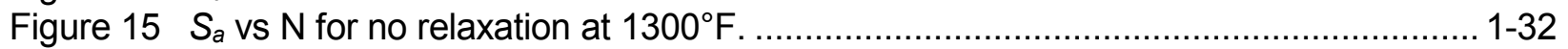

Figure 16 Relaxation data for heat SP-16 for $0.1 \%$ strain. .................................................. 1-33

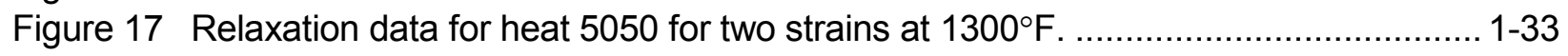

Figure 18 Effect of aging at $816^{\circ} \mathrm{C}\left(1500^{\circ} \mathrm{F}\right)$ on tensile properties of Hastelloy $\mathrm{N}$

(heat 5108) sheet samples........................................................................ 1-35

Figure 19 Effect of aging for 22,533 hours at $650^{\circ} \mathrm{C}\left(1202^{\circ} \mathrm{F}\right)$ on the tensile properties of

Hastelloy $\mathrm{N}$ (heat 5085)............................................................................. 1-36

Figure 20 Comparison of the yield strengths for weldments of Hastelloy $\mathrm{N}$ with those of the base metal. ........................................................................................... 1-38

Figure 21 Comparison of the ultimate tensile strengths for weldments of Hastelloy $\mathrm{N}$ with those of the base metal. ................................................................................ 1-38

Figure 22 Comparison of the tensile elongation for weldments of Hastelloy $\mathrm{N}$ with those

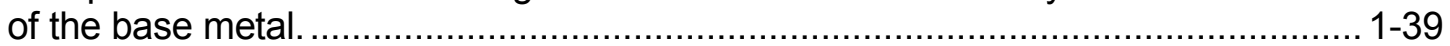

Figure 23 Trends for the stress-rupture of Hastelloy N compared with the scatter bands for base metal.......................................................................................... 1-40

Figure 24 Minimum creep rate scatter bands of Hastelloy $\mathrm{N}$ compared with the trends for base metal. ................................................................................................ 1-40

Figure 25 Stress-rupture of Hastelloy $\mathrm{N}$ welds at $1200^{\circ} \mathrm{F}$ compared with data for base metal........................................................................................................ 1-41

Figure 26 Mass change data as a function of time for corrosion experiments conducted in fluoride and chloride salts.................................................................................. $2-2$

Figure 27 Capsule testing apparatus at ORNL........................................................... 2-4

Figure 28 Schematic drawing of a thermal convection loop used for corrosion studies in molten fluoride at Oak Ridge National Laboratory............................................. 2-5

Figure 29 Corrosion of Inconel 600 in a thermal convection loop with uranium containing FLiNaK salt at a temperature of $815^{\circ} \mathrm{C}$ in the hot leg....................................... 2-6

Figure 30 Mass loss of coupons exposed to FLiNaK salt with various impurity contents.......... 2-7

Figure 31 Uranium (III) as a function of total uranium in a thermal convection loop containing $\mathrm{LiF}_{-} \mathrm{BeF}_{2}-\mathrm{ZrF}_{4}-\mathrm{UF}_{4}$ salt. 
Figure 32 Cracking behavior of Hastelloy $\mathrm{N}$ exposed for $260 \mathrm{~h}$ at $700^{\circ} \mathrm{C}$ to molten salt breeder reactor fuel salt containing $\mathrm{CrTe}$

Figure 33 Hastelloy $\mathrm{N}$ was fabricated with ${ }^{14} \mathrm{C}$, which appears dark in the autoradiograph, while precipitates have light contrast.

Figure 34 An example of missing detail and unidentifiable features in the microscopy from the MSRE project.

Figure 35 Some precipitates or inclusions are seen, but from this data the phase or nature of the precipitates cannot be determined.

Figure 36 This is one of the few TEM images from the MSRE era; it shows a precipitate of unknown type and some small cavities that may be helium bubbles.

Figure 37 Hastelloy $\mathrm{N}$ from the first group of surveillance samples from the core of the MSRE developed surface cracks after being strained.

Figure 38 The materials from the second group of surveillance samples in the MSRE included several versions of Hastelloy $\mathrm{N}$ modified with different alloying elements.

Figure 39 Example of a Hastelloy $\mathrm{N}$ sample from the third surveillance group from the MSRE.

Figure 40 G347A graphite (a) transverse and (b) axial dimensional changes as a function of irradiation temperature and dose.

Figure $41 \mathrm{SiC} / \mathrm{SiC}$ composites irradiated to $100 \mathrm{dpa}$ had brittle flexure behavior at a $319^{\circ} \mathrm{C}$ irradiation temperature but retained ductility for the $629^{\circ} \mathrm{C}$ irradiation case.

Figure 42 Fracture surfaces of flexural tests of $\mathrm{SiC} / \mathrm{SiC}$ composites before and after irradiation to $\sim 100 \mathrm{dpa}$.

Figure 43 Vessel made from roll-bonded Ni-clad steel; photo from Verbundmetalle $\mathrm{GmbH}$.

Figure 44 Weld overlay pipe fitting; image from Chongqing GLEN Flange Limited.

Figure 45 Explosion bonding of aluminum and stainless steel with tantalum interlayer; photo from High Energy Metals. 


\section{LIST OF TABLES}

Table 1 Candidate materials for MSR design. .......................................................... 1-2

Table 2 Nominal compositions of Hastelloy $\mathrm{N}$ and Incoloy $800 \mathrm{H}$, wt \%............................. 1-3

Table 3 Composition of 304 and related grades, wt $\%{ }^{*}$.............................................. 1-5

Table 4 Composition of 316 and related grades, wt $\%{ }^{*}$............................................. 1-7

Table 5 Chemical compositions of Haynes 230 and Haynes 242, wt \%. ............................ 1-8

Table 6 Codification status of Hastelloy N (UNS N1003), based on ASME BPVC, 2017 edition......................................................................................... 1-11

Table 7 Incoloy $800 \mathrm{H}$ code status (UNS N08810), based on ASME BPVC, 2017 edition................................................................................................. 1-13

Table 8 SS 304 code status (UNS S30400, S30409), based on ASME BPVC, 2017

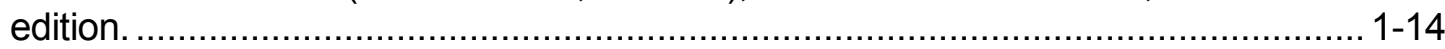

Table 9 SS 316 code status (UNS S31600, S31609), based on ASME BPVC, 2017

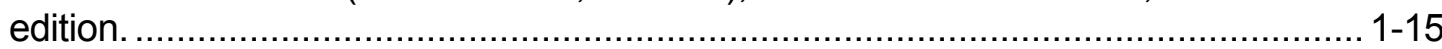

Table 10 Haynes 230 code status (UNS N06230), based on ASME BPVC, 2017 edition...... 1-17

Table 11 Haynes 242 code status (UNS N10242), based on ASME BPVC, 2017 edition...... 1-17

Table 12 Heats and product forms of Hastelloy-N tested in creep rupture by different

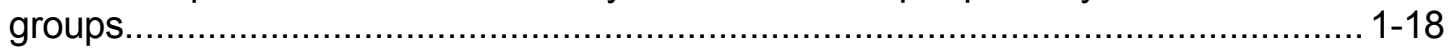

Table 13 Chemical composition of heats of Hastelloy N, wt \%. ...................................... 1-19

Table 14 Comparison of the Larson-Miller parametric model for data groupings................... 1-22

Table 15 Welds made in McCoy and Canonico study....................................................... 1-41

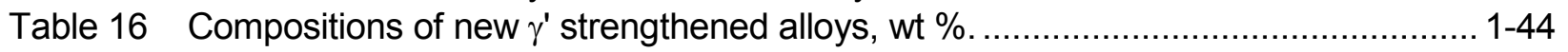

Table 17 Formation energies of fluoride and chloride compounds of some common alloy and salt constituents....................................................................................... 2-1

Table 18 Compositions of Hastelloy N through the MSRE project from Ref. [22] in weight

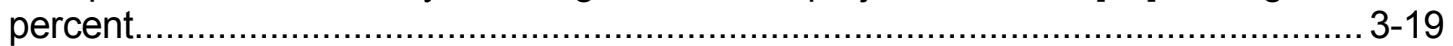

Table 19 Summary of data available for neutron-irradiated Hastelloy N. ............................ 3-20

Table 20 Alloy compositions (mass \%) of Hastelloy N family and Kurchatov Institute developed alloys........................................................................................ $3-25$

Table 21 Nominal nickel-based alloy compositions in wt \%. ....................................... 3-26

Table 22 ASME, Section III, Division 5 format................................................................ 4-1

Table 23 Permissible weld materials for Class A components.............................................. 4-4

Table 24 Temperature and time limits for HBB design parameters of Class A materials.......... 4-5

Table 25 Specifications and grades of permissible bolting materials for Class A

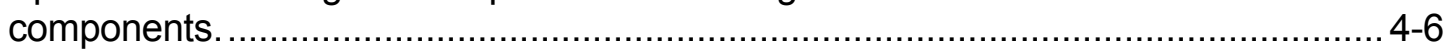

Table 26 HBB-Y paragraphs on data requirements for new Class A material. ...................... 4-6

Table 27 Availability of design information at different temperatures. ................................ 4-7 



\section{EXECUTIVE SUMMARY}

Material selection and qualification is an important consideration for the deployment of molten salt reactors (MSRs). This report summarizes the most important materials issues that must be considered for licensing MSRs. Because of the variety of MSR designs under consideration, this report considers materials for both fluoride and chloride applications, with both fast and thermal neutron spectra.

The report begins with a discussion of the high-temperature mechanical properties of commonly considered candidate structural alloys, with a focus on Hastelloy- $\mathrm{N}$ and its variants. Tensile, creep, and fatigue strength are discussed. Weldments and aging effects are also considered. It is determined that materials with high-temperature strength will be needed. Several suitable alloys may exist, including high-temperature nickel-based alloys and modified Hastelloy $\mathrm{N}$ variants. The incorporation of Hastelloy N into Section III, Division 5, the nuclear section, of the American Society of Mechanical Engineers (ASME) Boiler and Pressure Vessel Code (BPVC) as a Class B material for structural applications in the secondary loop is recommended. This action can readily be taken, as there exists a large database on creep rupture properties.

The next section details the compatibility of the materials with the molten salt environment. Early data from the Molten Salt Reactor Experiment (MSRE) at Oak Ridge National Laboratory (ORNL) showed acceptable compatibility of highly pure fluoride salts with Hastelloy- $\mathrm{N}$, but data acquired under other conditions are scattered and not well controlled. Data on materials in chloride salts are especially limited. It is recommended that standards be developed for experimentation in molten salts to produce a consistent data set so alloy behavior can be understood in different salt conditions. Thermodynamic data on alloy and salt combinations are also needed to better understand interfacial phenomena in MSRs. Further, there is a need for rate modeling to predict lifetimes of salt-facing materials.

The third section covers radiation damage in MSR-relevant materials. At present, there is less understanding of neutron damage in nickel-based alloys - the most common structural material candidates for MSRs - than in other common structural materials such as stainless and ferriticmartensitic steels. Expected radiation-related issues at service temperatures $\sim 350-650^{\circ} \mathrm{C}$ are helium embrittlement, swelling, neutron embrittlement, and irradiation-assisted stress-corrosion cracking. For service temperatures above $650^{\circ} \mathrm{C}$, several neutron effects, such as neutron embrittlement and swelling, are not expected; but helium embrittlement may still be lifetime limiting, and neutron irradiation data for this phenomenon are a priority research need. The original Hastelloy $\mathrm{N}$ has severe irradiation embrittlement issues and drops in strength above $\sim 700^{\circ} \mathrm{C}$, which make it unsuitable for some MSR designs. There is a significant lack of quality irradiation data for many of the metals, including Hastelloy N. Irradiation effects in graphite are better understood, although grades of graphite are known to behave differently; therefore, there is a need for experimental data on specific graphite grades to be used in proposed MSRs. The selection of any material for an MSR must consider the combined effects of irradiation and corrosion, for which there are very limited data for any of the materials under consideration.

The fourth section provides high-level descriptions of ASME BPVC Section III Division 5 construction rules for Class A (metallic) components and discussion of strategies to address the challenges for structural materials. By reducing the core outlet temperatures, using replaceable components, and implementing redox controls of the molten salt chemistries, some MSR developers have selected Type $316 \mathrm{H}$ SS as a construction material for their first-of-a-kind MSR applications. Data gaps have been identified for this first-to-market strategy. A strategy of cladding corrosion-resistant materials on salt-wetting surfaces of MSR components constructed of qualified 
Class A materials can be pursued for applications in nth-of-a-kind MSR systems. The code qualification of Hastelloy $\mathrm{N}$ as a Class $\mathrm{A}$ material for structural applications in the primary loop of an MSR is not recommended because of concerns regarding helium embrittlement and tellurium embrittlement if the redox chemistry of the molten salt is not well controlled (R.N. Wright and T.-L. Sham, Status of Metallic Structural Materials for Molten Salt Reactors, INL/EXT-18-45171, Idaho National Laboratory, Idaho Falls, ID, 2018.) Strategies to address long-term MSR materials needs for the requisite high-temperature strength, corrosion resistance, and irradiation-damage tolerance are being pursued by US Department of Energy Nuclear Energy University Program (NEUP) projects. Implementation of a materials surveillance program based on in situ, passive surveillance test articles that capture creep-fatigue damage and the effects of thermal aging, corrosion, and irradiation on mechanical properties would provide added confidence in MSR operation. A development effort to establish the technical basis of such a materials surveillance program is of high priority.

Candidate materials for MSRs were reviewed with emphasis on mechanical properties, including time-independent properties, creep rupture, fatigue, and thermal stability, along with material product form and weldability. Particularly, Hastelloy N, Incoloy $800 \mathrm{H}$, stainless steels (SSs) 304 and 316, and Haynes 230 and 242 are included in the review because they were or are being used in previous MSR fabrication or current concept designs and have the potential to be used in MSRs in the future. Among the candidates, Incoloy $800 \mathrm{H}$ and $304 \mathrm{SS}$ and $316 \mathrm{SS}$ are qualified as Class A materials in ASME BPVC Section III, Division 5, and can be used for the construction of Class A components in high-temperature reactors like MSRs. Some are not compatible readily with molten salt environments in MSRs and can be used with Hastelloy $\mathrm{N}$ cladding and lining.

In the long term, materials with a high permittable temperature range or high creep strength will be needed for MSR designs, especially considering the large pressure difference between the molten salt and the gaseous phase in the secondary heat exchangers. The review indicates a variety of alloys known as Hastelloy $\mathrm{N}$ variants have been developed, but a careful screening process is needed to identify the material with the best performance in various environments for codification in the next step. 


\section{ACKNOWLEDGMENTS}

This work was performed under contract with the U.S. Nuclear Regulatory Commission (NRC). The authors thank R. lyengar and G. Tartal, NRC program managers, for their support and guidance. A. Hull, S. Malik, N. McMurray, and B. Harris (NRC) provided valuable comments on the manuscript. The authors also thank $\mathrm{D}$. Counce (ORNL) for assistance with formatting and preparing the final document. 



\section{ACRONYMS AND ABBREVIATIONS}

\begin{tabular}{|c|c|}
\hline AFM & atomic force microscopy \\
\hline AHTR & advanced high temperature reactors \\
\hline ANS & American Nuclear Society \\
\hline ASME & American Society of Mechanical Engineers \\
\hline ASTM & American Society for Testing and Materials \\
\hline $\mathrm{BPVC}$ & Boiler and Pressure Vessel Code (ASME) \\
\hline CALPHAD & calculation of phase diagrams \\
\hline $\mathrm{cpm}$ & cycle per minute \\
\hline CTE & coefficient of thermal expansion \\
\hline $\mathrm{CVI}$ & chemical vapor infiltration \\
\hline $\mathrm{DHX}$ & Direct Reactor Auxiliary Cooling System heat exchanger \\
\hline DOE & Department of Energy \\
\hline dpa & displacements per atom \\
\hline DPS & dispersion-precipitation-strengthened \\
\hline DRACS & Direct Reactor Auxiliary Cooling System \\
\hline EBR & Experimental Breeder Reactor \\
\hline EBSD & electron backscatter diffraction \\
\hline EPMA & electro-probe microanalysis \\
\hline ETR & experimental test reactor \\
\hline fcc & face centered cubic \\
\hline FHR & fluoride salt-cooled high-temperature reactor \\
\hline FHR-DR & fluoride salt-cooled high-temperature reactor-demonstration reactor \\
\hline FHTR-MIT & $\begin{array}{l}\text { fluoride salt-cooled high-temperature reactor at Massachusetts Institute of } \\
\text { Technology }\end{array}$ \\
\hline FLiBe & lithium fluoride and beryllium fluoride \\
\hline FLiNaK & eutectic LiF-NaF-KF molten salt \\
\hline $\mathrm{FZ}$ & fusion zone \\
\hline GBE & grain boundary engineering \\
\hline GMAW & gas metal arc welding \\
\hline GTAW & gas tungsten arc welding \\
\hline HAZ & heat-affected zone \\
\hline HFIR & High Flux Isotope Reactor \\
\hline HTGR & high temperature gas reactor \\
\hline $\mathrm{HX}$ & heat exchanger \\
\hline INL & Idaho National Laboratory \\
\hline $\mathrm{I}-\mathrm{PHX}$ & intermediate to power cycle heat exchanger \\
\hline LBW & laser beam welding \\
\hline LMP & Larson-Miller parameter \\
\hline LWR & light water reactor \\
\hline MCR & minimum creep rate \\
\hline MSBR & molten Salt Breeder Reactor \\
\hline MSR & molten salt reactor \\
\hline MSRE & Molten Salt Reactor Experiment \\
\hline NEUP & Nuclear Energy University Program \\
\hline NGNP & Next Generation Nuclear Plant \\
\hline NRC & Nuclear Regulatory Commission \\
\hline
\end{tabular}




\begin{tabular}{|l|l|}
\hline NRT & Norgett-Robinson-Torrens radiation damage model \\
\hline ORNL & Oak Ridge National Laboratory \\
\hline ORR & Oak Ridge Reactor \\
\hline PB-FHR & pebble-bed fluoride salt-cooled high-temperature reactor \\
\hline P-IHX & primary-to-intermediate heat exchanger \\
\hline PWHT & post-weld heat treatment \\
\hline RT & oom temperature \\
\hline SEE & standard error of estimate \\
\hline SEM & scanning electron microscopy \\
\hline SG & steam generator \\
\hline SG-ETD & Subgroup on Elevated Temperature Design (ASME BPVC) \\
\hline SHX & secondary heat exchanger \\
\hline SMAW & shielded-metal-arc welding \\
\hline SRF & stress rupture factor \\
\hline SS & stainless steel \\
\hline SSC & systems, structures, and components \\
\hline TE & total elongation \\
\hline TEM & transmission electron microscopy \\
\hline TF & tritium fluoride \\
\hline TMP & thermomechanical processing \\
\hline TMSR & thorium molten salt reactor \\
\hline UE & uniform elongation \\
\hline UNS & unified numbering system \\
\hline UTS & ultimate tensile strength \\
\hline WG-HTLR & Working Group on High Temperature Liquid Reactors (ASME BPVC) \\
\hline XRD & x-ray diffraction \\
\hline YS & yield stress \\
\hline
\end{tabular}

Elements
\begin{tabular}{|l|l|l|l|l|l|}
\hline $\mathrm{Al}$ & aluminum & $\mathrm{K}$ & potassium & $\mathrm{Re}$ & rhenium \\
\hline $\mathrm{Ar}$ & argon & $\mathrm{La}$ & lanthanum & $\mathrm{Ru}$ & rubidium \\
\hline $\mathrm{B}$ & boron & $\mathrm{Mg}$ & magnesium & $\mathrm{S}$ & sulfur \\
\hline $\mathrm{C}$ & carbon & $\mathrm{Mn}$ & manganese & $\mathrm{Si}$ & silicon \\
\hline $\mathrm{Co}$ & cobalt & $\mathrm{Mo}$ & molybdenum & $\mathrm{Tc}$ & technetium \\
\hline $\mathrm{Cr}$ & chromium & $\mathrm{Nb}$ & niobium & $\mathrm{Ti}$ & titanium \\
\hline $\mathrm{Fe}$ & iron & $\mathrm{Ni}$ & nickel & $\mathrm{W}$ & tungsten \\
\hline $\mathrm{He}$ & helium & $\mathrm{P}$ & phosphorus & Xe & xenon \\
\hline
\end{tabular}




\section{INTRODUCTION}

This report reviews existing information on candidate materials for molten salt reactors (MSRs).

The discussion is organized into three main topic areas:

1. High-temperature mechanical properties, including time-independent properties, creep resistance, fatigue, and aging effects

2. Compatibility of candidate materials with the molten salt environment

3. Irradiation effects in structural and moderator materials

For each topic area, the current state of knowledge is discussed and knowledge gaps are identified. Discussions are informed by the conditions proposed by leading MSR vendors, including temperature ranges, material candidates, salt chemistries, and irradiation conditions. The most prominent MSR designs are those currently promoted by private vendors. Although the designs are all different, they can be divided into three main classes:

1. Reactors that utilize chloride salts-almost always fast reactors. The chloride salt acts as both coolant and fuel medium, with fuel generally in the form of uranium chloride.

2. Fluoride-fueled reactors that utilize a thermal spectrum and have either uranium or thorium fluorides dissolved in the coolant/fuel medium.

3. The fluoride salt-cooled reactor, which uses solid fuel and uses fluoride salts as a coolant only; one of the designs, advanced high-temperature reactor (AHTR), is briefly reviewed in Appendix A.

The goal of this work is to review current understanding regarding materials issues in MSRs and identify knowledge gaps and research priorities for materials research in support of MSR licensing and regulation.

\section{MECHANICAL PROPERTIES}

Several high-temperature alloys were identified for the review of this report, including Hastelloy-N, Incoloy $800 \mathrm{H}$, stainless steels (SSs) 304 \&316, Haynes 230, and Haynes 242. The selection of these alloys is based on their potential use in MSR applications. The use of the materials in various designs and codifications is given in Table 1. These alloys are described briefly in Section 1.1 with emphasis on the mechanical properties, thermal stability, resistance to MSR environments, and potential use and consideration in MSR application. 
Table 1 Candidate materials for MSR design .

\begin{tabular}{|c|c|c|c|c|}
\hline Materials & Working temp, ${ }^{\circ} \mathrm{C}$ & Codification & Potential MSR use & MSR design \\
\hline $\begin{array}{l}\text { Hastelloy } \\
\mathrm{N}\end{array}$ & $\begin{array}{l}\text { Sect. VIII-1, } 704^{\circ} \mathrm{C} \\
\left(1300^{\circ} \mathrm{F}\right)\end{array}$ & $\begin{array}{l}\text { Sect. VIII-1 \& } \\
2, \\
\text { Sect. XII }\end{array}$ & $\begin{array}{l}\text { Reactor vessel, core } \\
\text { barrel, control rod } \\
\text { system, pebble } \\
\text { injection and pebble } \\
\text { defuel mechanisms, } \\
\text { piping and pumps in } \\
\text { primary/ secondary } \\
\text { coolant loop; primary } \\
\text { and secondary heat } \\
\text { exchangers }\end{array}$ & $\begin{array}{l}\text { ORNL MSRE [1], } \\
\text { ORNL FHR-DR [2, 3]; } \\
\text { Mark-1 PB-FHR [4]; } \\
\text { FHTR-MIT [5]; China, } \\
\text { TMSR [6] }\end{array}$ \\
\hline $\begin{array}{l}\text { Incoloy } \\
800 \mathrm{H}\end{array}$ & $\begin{array}{l}\text { Sect. I, } 816^{\circ} \mathrm{C} \\
\left(1500^{\circ} \mathrm{F}\right) ; \\
\text { Sect. VIII-1, } 982^{\circ} \mathrm{C} \\
\left(1800^{\circ} \mathrm{F}\right)\end{array}$ & $\begin{array}{l}\text { Sect. I; } \\
\text { Sect. III-1 \& } 5 \\
\text { Sect. VIII-1 \& } \\
\text { 2; Sect. XII }\end{array}$ & $\begin{array}{l}\text { Reactor vessel, } \\
\text { primary and } \\
\text { secondary piping; } \\
\text { core internal } \\
\text { structures }\end{array}$ & $\begin{array}{l}\text { NGNP }[7,8] \text {; ORNL } \\
\text { FHR-DR, lined w/ } \\
\text { Hastelloy N [2, 3]; } \\
\text { Mark-1 PB-FHR [4] }\end{array}$ \\
\hline SS $304 \mathrm{H}$ & $\begin{array}{l}\text { Sect. I, } 816^{\circ} \mathrm{C} \\
\left(1500^{\circ} \mathrm{F}\right) ; \\
\text { Sect. VIII-1, } 816^{\circ} \mathrm{C} \\
\left(1500^{\circ} \mathrm{F}\right)\end{array}$ & $\begin{array}{l}\text { Sect. I; } \\
\text { Sect. III-1 \& } 5 \\
\text { Sect. VIII-1 \& } \\
\text { 2; Sect. XII }\end{array}$ & $\begin{array}{l}\text { Baseline materials for } \\
\text { MSR design }\end{array}$ & $\begin{array}{l}\text { Mark-1 PB-FHR [4]; } \\
\text { FHTR-MIT [5] }\end{array}$ \\
\hline SS $316 \mathrm{H}$ & $\begin{array}{l}\text { Sect. I, } 816^{\circ} \mathrm{C} \\
\left(1500^{\circ} \mathrm{F}\right) ; \\
\text { Sect. VIII-1, } 816^{\circ} \mathrm{C} \\
\left(1500^{\circ} \mathrm{F}\right)\end{array}$ & $\begin{array}{l}\text { Sect. I; } \\
\text { Sect. III-1 \& } 5 \\
\text { Sect. VIII-1 \& } \\
\text { 2; Sect. XII }\end{array}$ & $\begin{array}{l}\text { Reactor vessel, guard } \\
\text { vessel, piping, and } \\
\text { heat exchangers in } \\
\text { primary and } \\
\text { secondary loops, core } \\
\text { internal structures }\end{array}$ & $\begin{array}{l}\text { Mark-1 PB-FHR [4]; } \\
\text { FHTR-MIT [5] }\end{array}$ \\
\hline $\begin{array}{l}\text { Haynes } \\
230\end{array}$ & $\begin{array}{l}\text { Sect. I, } 899^{\circ} \mathrm{C} \\
\left(1650^{\circ} \mathrm{F}\right) ; \\
\text { Sect. VIII- } 1,899^{\circ} \mathrm{C} \\
\left(1800^{\circ} \mathrm{F}\right) ; \\
\text { Sect. XII, } 343^{\circ} \mathrm{C} \\
\left(650^{\circ} \mathrm{F}\right)\end{array}$ & $\begin{array}{l}\text { Sect. I; } \\
\text { Sect. VIII-1; } \\
\text { Sect. XII }\end{array}$ & $\begin{array}{l}\text { Pressure vessel and } \\
\text { piping in power loop }\end{array}$ & NGNP $[7,8]$ \\
\hline $\begin{array}{l}\text { Haynes } \\
242\end{array}$ & $\begin{array}{l}\text { Sect. VIII-1, } 538^{\circ} \mathrm{C} \\
\left(1000^{\circ} \mathrm{F}\right)\end{array}$ & Sect. VIII-1 & $\begin{array}{l}\text { Secondary heat } \\
\text { exchanger }\end{array}$ & INL SHX [9] \\
\hline
\end{tabular}

\subsection{Rational e for Selecting the Materials}

\subsubsection{Hastelloy $\mathbf{N}$}

\subsubsection{Main features}

Hastelloy N (UNS N10003), also known as Alloy N, INOR-8, is a Ni-based alloy containing Mo, Cr, $\mathrm{Fe}, \mathrm{C}$, and small amounts of several other elements, as shown in Table 2. It is the subject of several reviews [10-13]. Developed at Oak Ridge National Laboratory (ORNL) specifically for 
applications in molten fluoride salt systems, the alloy provides good resistance to molten fluoride salts in the temperature range of $704-871^{\circ} \mathrm{C}\left(1300-1600^{\circ} \mathrm{F}\right)$. This is why it is one of the top selections for MSR designs.

Table 2 Nominal composition s of Hastelloy $\mathbf{N}$ and Incoloy $800 \mathrm{H}$, wt \%.

\begin{tabular}{|c|c|c|c|c|c|c|c|c|c|c|c|}
\hline & $\mathbf{N i}$ & Mo & Cr & $\mathrm{Fe}$ & Si & Mn & C & Co & $\mathrm{Cu}$ & W & $\mathrm{Al}+\mathrm{Ti}$ \\
\hline $\begin{array}{c}\text { Hastelloy } \\
\text { N }\end{array}$ & Bal. & 16 & 7 & $\leq 5$ & $\leq 1$ & $\leq 0.08$ & $\leq 0.08$ & $\leq 0.20$ & $\leq 0.35$ & $\leq 0.50$ & $\leq 0.35$ \\
\hline $\begin{array}{c}\text { Incoloy } \\
800 \mathrm{H}\end{array}$ & 30-35 & & $19-23$ & $\begin{array}{l}39.5 \\
\min \end{array}$ & & & $\begin{array}{c}0.05- \\
0.10\end{array}$ & & & & $\begin{array}{c}0.30- \\
1.20\end{array}$ \\
\hline
\end{tabular}

Hastelloy $\mathrm{N}$ also has good oxidation resistance in air environment and may be used for continuous operation at temperatures up to $982^{\circ} \mathrm{C}\left(1800^{\circ} \mathrm{F}\right)$. The alloy is a solid solution material, and it is normally solution-annealed in the temperature range of $1093-1177^{\circ} \mathrm{C}\left(2000-2150^{\circ} \mathrm{F}\right)$, followed by rapid air cooling. Metallographic examinations have shown that its strengthening elements remain in solid solution in the $593-871^{\circ} \mathrm{C}\left(1100-1600^{\circ} \mathrm{F}\right)$ range. Carbide precipitates appear randomly distributed in the grain boundaries and interiors. Agglomeration of the carbides is observed after long-term exposure at $649-760^{\circ} \mathrm{C}\left(1200-1400^{\circ} \mathrm{F}\right)$. However, no precipitation hardening is indicated by high-temperature mechanical testing; and for prolonged periods at $816^{\circ} \mathrm{C}\left(1500^{\circ} \mathrm{F}\right)$, tensile test results have indicated no tendency toward embrittlement.

Furthermore, the alloy did not exhibit any notch sensitivity during stress-rupture properties evaluation using smooth and notched specimens [14, 15].

Various product forms of Hastelloy $\mathrm{N}$ can be manufactured by processing methods regularly used for Ni-base alloys, such as forging, extrusion, hot rolling, and cold rolling. The hot working range for Hastelloy $\mathrm{N}$ is between 871 and $1177^{\circ} \mathrm{C}\left(1600-2150^{\circ} \mathrm{F}\right)$. Forging can be conducted in the temperature range from 1038 to $1232^{\circ} \mathrm{C}$ and hot rolling from 1024 to $1204^{\circ} \mathrm{C}\left(1875-2200^{\circ} \mathrm{F}\right)$. Because the material work-hardens readily, intermediate annealing is normally required after cold rolling of sheets.

The alloy has good weldability and can be readily welded by the inert gas tungsten arc welding (GTAW) process. The weldment normally requires no preheat nor post-heat and is not subject to air hardening during welding.

\subsubsection{Potential MSR use and consideration}

The uses of Hastelloy $\mathrm{N}$, as shown in Table 1, include the reactor vessel, piping, heat exchanger $(\mathrm{HX})$, and core internal structures as used or discussed in the ORNL MSRE, ORNL FHR-DR (fluoride salt-cooled high-temperature reactor-demonstration reactor, Mark-1 PB-FHR (pebblebed fluoride salt-cooled high-temperature reactor), FHTR-MIT (fluoride salt-cooled hightemperature reactor at Massachusetts Institute of Technology), and TMSR (thorium molten salt reactor) in China [1-6]. It is a good candidate material for FHR heat exchangers-where its high corrosion resistance allows the use of thinner tube walls, resulting in more compact geometriesand for piping and other components in the intermediate and Direct Reactor Auxiliary Cooling System (DRACS) loops, which may use salts with higher corrosivity than FLiBe (lithium fluoride and beryllium fluoride). 
Hastelloy $\mathrm{N}$ has relatively poor performance under neutron irradiation. It is a reasonably wellproven alloy for structural components that operate at temperatures less than or equal to $704^{\circ} \mathrm{C}$ in low-neutron-flux regions. According to the third FHR workshop, Hastelloy $\mathrm{N}$ can tolerate less than or 1 dpa [12]. It will be problematic if irradiated above 2 or $3 \mathrm{dpa}$. In high-neutron-flux regions, high-nickel $(\mathrm{Ni})$ alloys, because of their embrittlement characteristics, do not have acceptable performance.

Extensive experience with Hastelloy $\mathrm{N}$ was obtained during the MSRE program in an $8 \mathrm{MW}$ test reactor at ORNL [1]. This alloy is only codified for ASME Boiler and Pressure Vessel Code (BPVC) Sections VIII-Rules for Construction of Pressure Vessels, and XII-Rules for Construction and Continued Service of Transport Tanks. It is not codified in ASME BPVC Section III-Rules for Construction of Nuclear Facility Components, particularly Division 5-High Temperature Reactors.

\subsubsection{Incoloy $800 \mathrm{H}$}

\subsubsection{Main features}

Incoloy $800 \mathrm{H}$ (UNS N08810) is one of the Incoloy 800 series alloys, invented by the Special Metals Corporation; $800 \mathrm{H}$ is designated as Grade 2 with an annealing temperature of approximately $1150^{\circ} \mathrm{C}\left(2100^{\circ} \mathrm{F}\right)$ [16]. The carbon content for Incoloy $800 \mathrm{H}$ is 0.05 to $0.10 \%$, and its chemical composition is provided in Table 2.

Incoloy $800 \mathrm{H}$ is an austenitic, solid solution alloy. Titanium nitrides, Ti carbides, and $\mathrm{Cr}$ carbides normally appear in the alloy's microstructure. The nitrides are stable at all temperatures below the melting point and therefore are unaffected by heat treatment. The carbon content in Incoloy $800 \mathrm{H}$ produces high-temperature strength and resistance to creep and rupture. Incoloy $800 \mathrm{H}$ uses solution annealing as a final stage of production so that the carbon is in a condition to make its optimum contribution to high-temperature properties. The solution annealing also results in a large grain size, which further contributes to strength and resistance to creep and rupture at high temperatures. Incoloy $800 \mathrm{H}$ can be delivered as extruded tubing and hot-rolled plates.

Because of its high $\mathrm{Cr}$ and $\mathrm{Ni}$ contents, Incoloy $800 \mathrm{H}$ has excellent resistance to oxidation. The $\mathrm{Cr}$ in the alloy promotes the formation of protective surface oxide, and the Ni enhances the protection, especially during cyclic exposure to high temperatures.

This alloy is austenitic with a face-centered cubic (fcc) crystallographic structure. Austenitic alloys, in comparison with ferritic materials, typically require more energy to deform; but because of the many crystallographic planes available, they are very ductile. Thus, large amounts of cold work can be performed before annealing is necessary. The specific annealing procedure for this alloy depends on the amount of cold work, target grain size, and cross section of the material. Stress relief begins at about $540^{\circ} \mathrm{C}\left(1000^{\circ} \mathrm{F}\right)$ and is virtually complete after $870^{\circ} \mathrm{C}\left(1600^{\circ} \mathrm{F}\right)$ for a time commensurate with thickness. Optimum resistance to time-dependent deformation (creep) at elevated temperatures is obtained by heating to a temperature to cause grain growth. The temperature normally used is $1150-1200^{\circ} \mathrm{C}\left(2100-2200^{\circ} \mathrm{F}\right)$. Depending on the size and furnace characteristics, the time at temperature is adjusted to achieve a grain size of ASTM No. 5 or coarser. The temperature and time should also be adjusted to limit excessive grain growth. One disadvantage of excessive grain growth is the lowering of toughness after exposure to elevated temperature. 
Incoloy $800 \mathrm{H}$ has good weldability. For temperatures up to $790^{\circ} \mathrm{C}\left(1450^{\circ} \mathrm{F}\right)$, the Inco-Weld $\mathrm{A}$ Electrode is used for shielded-metal-arc welding (SMAW), and Inconel filler metal 82 is used for gas-shielded welding.

\subsubsection{Potential MSR use and considerations}

Incoloy $800 \mathrm{H}$ is used in the design of MSR reactor vessel and primary loop of coolant as described in ORNL FHR-DR; Mark-1 PB-FHR; FHTR-MIT [2-5].

The depletion of $\mathrm{Cr}$ makes this alloy susceptible to the corrosion of fluoride molten salt. Thus, a lining of Hastelloy $\mathrm{N}$ is used in the design to protect the structure from the corrosion at high temperatures.

This alloy can be found in many other applications involving long-term exposure to elevated temperatures and corrosive environments including hydrocarbon processing industry. Industrial heating is another area of wide usage for Incoloy $800 \mathrm{H}$. In various types of heat-treating furnaces, this alloy is used for radiant tubes, muffles, retorts, and assorted furnace fixtures. Incoloy $800 \mathrm{H}$ is also used in power generation for steam superheating tubing and high temperature HXs in gascooled nuclear reactors. But, no experience of this alloy is available with use in MSRs.

Incoloy $800 \mathrm{H}$ is approved under the ASME BPVC Section I, and Section VIII, Divisions 1 and 2. The use of Incoloy $800 \mathrm{H}$ for nuclear construction is addressed under ASME BPVC Section III-5.

\subsubsection{Stainless Steel (SS) 304}

\subsubsection{Main features}

UNS S30400 (grade 304, or SS 304 as seen in Table 3) is the greatest stainless success story. SS 304L is a low-carbon 304 often used to avoid possible sensitization corrosion in welded components. $304 \mathrm{H}$ SS has a higher carbon content than $304 \mathrm{~L}$, which increases the strength (particularly at temperatures above about $500^{\circ} \mathrm{C}$ ) [17].

Table 3 Composition of 304 and related grades, wt \%*.

\begin{tabular}{|ccccccccc|}
\hline Grade & & C & Si & Mn & $\mathbf{P}$ & $\mathbf{S}$ & $\mathbf{C r}$ & $\mathbf{N i}$ \\
\hline UNS S30400 & 304 & 0.08 & 1.00 & 2.00 & 0.045 & 0.03 & $18.0-20.0$ & $8.0-10.5$ \\
UNS S30403 & $304 \mathrm{~L}$ & 0.03 & 1.00 & 2.00 & 0.045 & 0.03 & $18.0-20.0$ & $8.0-12.0$ \\
UNS S30409 & $304 \mathrm{H}$ & $0.04-0.10$ & 1.00 & 2.00 & 0.045 & 0.03 & $18.0-20.0$ & $8.0-12.0$ \\
\hline
\end{tabular}

* Single values are maximum specification limits; the limits are specified in ASTM A240 for plate, sheet and strip.

SS 304 has excellent corrosion resistance in a wide range of media. It resists ordinary rusting in most architectural applications and food processing environments. In warm chloride environments, 304 is subject to pitting and crevice corrosion and to stress corrosion cracking when subjected to tensile stresses beyond about $50^{\circ} \mathrm{C}$.

SS 304 has good oxidation resistance in intermittent service to $870^{\circ} \mathrm{C}\left(1600^{\circ} \mathrm{F}\right)$ and in continuous service to $925^{\circ} \mathrm{C}\left(1700^{\circ} \mathrm{F}\right)$. Continuous use of 304 in the $425-860^{\circ} \mathrm{C}\left(800-1580^{\circ} \mathrm{F}\right)$ range is not recommended if subsequent exposure to room-temperature (RT) aqueous environments is 
anticipated. SS $304 \mathrm{~L}$ is more resistant to carbide precipitation and can be used in the $425-860^{\circ} \mathrm{C}$ $\left(800-1580^{\circ} \mathrm{F}\right)$ temperature range. Where high-temperature strength is important, higher carbon values are required. Section 3.1.1 of this report also discusses the impact of carbide precipitation.

Annealing is the main heat treatment carried out on SS 304. It is accomplished by heating to $1010-1120^{\circ} \mathrm{C}\left(1850-2050^{\circ} \mathrm{F}\right)$ and then rapidly cooling - usually by water quenching. SS 304 has excellent forming characteristics. It can be deep drawn without intermediate heat softening-a characteristic that has made this grade dominant in the manufacture of drawn stainless parts, such as sinks and saucepans. It is readily brake or roll formed into a variety of other parts for application in the industrial, architectural, and transportation fields.

SS 304 has outstanding weldability and all standard welding techniques can be used. Post-weld annealing is often not required to restore 304's corrosion resistance, although appropriate postweld clean-up is recommended.

SS 304 is available in all stainless product forms, including coil, sheet, plate, strip, tube, pipe, fittings, bars, angles, wire, fasteners, castings and some others.

\subsubsection{Potential MSR use and considerations}

SS 304 serves as a baseline material in some FHR designs [4, 5] because of the experience obtained with light water reactors (LWRs), its qualification for ASME BPVC Section III-5, and availability of vendors for manufacturing the nuclear grade of SS 304.

It is subject to $\mathrm{Cr}$ depletion in fluoride salts owing to the large percentage of $\mathrm{Cr}$ in the composition. The use of SS 304 in MSRs will be limited to the systems and components that have limited or no contact with molten salts. In addition, alternative grades to 304 should be considered in certain applications requiring heavy section welding, substantial machining, high strength or hardness, or strips with very high cold-rolled strength.

\section{1 .4 SS 316}

\subsubsection{Main features}

SS 316 (UNS S31600) is the second most popular grade in the SS family. SS 316 has the same mechanical, physical, and fabrication characteristics as 304 with better corrosion resistance, particularly to pitting corrosion in chloride environments [18]. Table 4 compares three grades of SS 316. SS $316 \mathrm{~L}$ is a low-carbon 316 often used to avoid possible sensitization corrosion in welded components. SS $316 \mathrm{H}$ has a higher carbon content than $316 \mathrm{~L}$, which increases its strength, particularly at temperatures above about $500^{\circ} \mathrm{C}\left(932^{\circ} \mathrm{F}\right)$; but it should not be used for applications where sensitization corrosion could be expected.

SS 316 has excellent corrosion resistance in a wide range of media. Its main advantage over SS 304 is its increased ability to resist pitting and crevice corrosion in warm chloride environments. In hot chloride environments, SS 316 is subject to pitting and crevice corrosion and to stress corrosion cracking when subjected to tensile stresses beyond about $50^{\circ} \mathrm{C}$. Like SS 304,316 has good oxidation resistance in intermittent service to $870^{\circ} \mathrm{C}\left(1600^{\circ} \mathrm{F}\right)$ and in continuous service to $925^{\circ} \mathrm{C}\left(1700^{\circ} \mathrm{F}\right)$. Continuous use of 316 in the $425-860^{\circ} \mathrm{C}$ range is not recommended if subsequent exposure to RT aqueous environments is anticipated. 
Solution annealing is the main heat treatment carried out on SS 316. It is done by heating to $1010-1120^{\circ} \mathrm{C}$ and rapidly cooling, usually by water quenching.

Table 4 Composition of 316 and related grades, wt \%*.

\begin{tabular}{|ccccccccccc|}
\hline \multicolumn{1}{|c}{ Grade } & $\mathbf{C}$ & $\mathbf{M n}$ & $\mathbf{S i}$ & $\mathbf{P}$ & $\mathbf{S}$ & $\mathbf{C r}$ & $\mathbf{N i}$ & $\mathbf{M o}$ & $\mathbf{N}$ \\
\hline $\begin{array}{c}\text { UNS } \\
\text { S31600 }\end{array}$ & 316 & 0.08 & 2.0 & 0.75 & 0.045 & 0.03 & $16.0-18.0$ & $10.0-14.0$ & $2.0-3.0$ & 0.10 \\
UNS & $316 \mathrm{~L}$ & 0.03 & 2.0 & 0.75 & 0.045 & 0.03 & $16.0-18.0$ & $10.0-14.0$ & $2.0-3.0$ & 0.10 \\
S31603 & & & & & & & & & & \\
UNS & $316 \mathrm{H}$ & $0.04-$ & 2.0 & 0.75 & 0.045 & 0.03 & $16.0-18.0$ & $10.0-14.0$ & $2.0-3.0$ & - \\
S31609 & & 0.10 & & & & & & & & \\
\hline
\end{tabular}

${ }^{*}$ Both $316 \mathrm{~L}$ and $316 \mathrm{H}$ are available in plate and pipe.

\subsubsection{Potential MSR use and considerations}

SS 316 is used in the FHR pressure vessel, piping, and HX [4,5]. Several noticeable aspects make it attractive. (1) SS 316 has a demonstrated chemical compatibility in clean FLiBe in the absence of a neutron field [19]. (2) There is significant experience with SS 316 in the temperature and fluence regime of LWRs as fuel support structures, core barrels, and flow baffle plates [20]. (3) SS 316 is more readily available than Hastelloy-N. (4) It is codified for ASME BPVC Section III Division 5.

SS 316 has been shown to have excellent corrosion resistance with FLiBe if beryllium metal is used to control the salt fluorine potential [19]. SS 316 may be an attractive structural material for FHR reactor vessels because, under power and normal shutdown conditions, they will operate at the core inlet temperature. Because corrosion will be driven by solubility, little corrosion would be expected for the reactor vessel, as it remains at the coldest temperature in the reactor system; given the relatively thick cross section of the vessel, solubility-driven corrosion would not be an important degradation mechanism for the reactor vessel in any case. SS 316 is an attractive candidate material for use in FHRs because of its good tolerance for neutron irradiation compared with high-Ni superalloys like Hastelloy $\mathrm{N}$ and Incoloy $800 \mathrm{H}$. The good tolerance of SS 316 to neutron irradiation would reduce the required neutron reflector thickness. With a pool design, the reactor vessel is the single most important element of the primary pressure boundary that prevents loss-of-coolant accidents. In this case, the extensive experience base provided by SS 316 may also be of value, although the operating temperature for use in FHRs will be higher than that in most previous experience.

SS $316 \mathrm{H}$ is allowed for use at temperatures up to $816^{\circ} \mathrm{C}\left(1500^{\circ} \mathrm{F}\right)$ in Section III-5. This part of the ASME Code covers SS $316 \mathrm{H}$ in terms of high-temperature strength, creep, and creep-fatigue effects up to a design life of 300,000 h. However, the Code does not address other key requirements associated with the design of the components, such as corrosion and neutron embrittlement. 


\subsubsection{Haynes 230}

\subsubsection{Main features}

Haynes 230 (UNS N06230) alloy is an Ni-Cr-W-Mo alloy (Table 5) that has excellent hightemperature strength, resistance to oxidizing environments up to $1149^{\circ} \mathrm{C}\left(2100^{\circ} \mathrm{F}\right)$, and long-term thermal stability. It is readily fabricated and formed and is castable [21]. Other attractive features include lower thermal expansion characteristics than most high-temperature alloys, and a pronounced resistance to grain coarsening with prolonged exposure to high temperatures.

Haynes 230 may be forged or otherwise hot-worked, provided it is held at $1177^{\circ} \mathrm{C}\left(2150^{\circ} \mathrm{F}\right)$ for a time sufficient to bring the entire piece to temperature. Because of its good ductility, the alloy is also readily formed by cold working. However, all hot- or cold- worked parts should be annealed and rapidly cooled to restore the best balance of properties.

Wrought 230 alloy is furnished in a solution heat-treated condition. The alloy is solution heattreated in the range of 1177 to $1246^{\circ} \mathrm{C}\left(2150\right.$ to $\left.2275^{\circ} \mathrm{F}\right)$ and rapidly cooled or water-quenched for optimum properties. Annealing at temperatures lower than solution heat-treating temperatures will produce some carbide precipitation in Haynes 230, which may marginally affect the alloy's strength and ductility. Haynes 230 may be cast using traditional air-melt sand mold or vacuummelt investment casting foundry practices. Silicon levels at the high end of the specification range are recommended for enhanced fluidity. Castings may be used in either the as-cast or solution heat-treated condition, depending upon property requirements.

Table 5 Chemical composition s of Haynes 230 and Haynes 242, wt \%.

\begin{tabular}{|c|c|c|c|c|c|c|c|c|c|c|c|c|c|c|}
\hline & $\mathbf{N i}$ & Cr & $\mathbf{W}$ & Mo & $\mathrm{Fe}$ & Co & Mn & Si & $\mathrm{Nb}$ & Al & Ti & C & La & B \\
\hline $\begin{array}{l}\text { Haynes } \\
230\end{array}$ & 57 & 22 & 14 & 2 & $\begin{array}{l}3 \\
\max \end{array}$ & $\begin{array}{l}5 \\
\max \end{array}$ & 0.5 & 0.4 & $\begin{array}{l}0.5 \\
\max \end{array}$ & 0.3 & $\begin{array}{l}0.1 \\
\max \end{array}$ & 0.1 & 0.02 & $\begin{array}{l}0.015 \\
\max \end{array}$ \\
\hline $\begin{array}{l}\text { Haynes } \\
242\end{array}$ & 65 & 8 & & 25 & $\begin{array}{l}2 \\
\max \end{array}$ & $\begin{array}{l}1 \\
\max \end{array}$ & $\begin{array}{l}0.8 \\
\max \end{array}$ & $\begin{array}{l}0.8 \\
\max \end{array}$ & & $\begin{array}{l}0.5 \\
\max \end{array}$ & & $\begin{array}{l}0.03 \\
\max \end{array}$ & & $\begin{array}{l}0.006 \\
\max \end{array}$ \\
\hline
\end{tabular}

Haynes 230 is a solid-solution-strengthened material that is particularly effective for very long-term applications at temperatures of $650^{\circ} \mathrm{C}\left(1200^{\circ} \mathrm{F}\right)$ or more and is capable of outlasting SSs and nickel alloys by as much as 100 to 1 , depending upon the temperature. Its fatigue life is comparable to that of alloy 625 and better than alloy 617 .

Haynes 230 exhibits excellent retained strength and ductility after long-term thermal exposure at intermediate temperatures. It does not exhibit sigma phase, mu phase, or other deleterious phase formation even after $16,000 \mathrm{~h}$ of exposure at temperatures from 649 to $871^{\circ} \mathrm{C}\left(1200\right.$ to $\left.1600^{\circ} \mathrm{F}\right)$. Principal phases precipitated from solid solution are all carbides.

Haynes 230 exhibits excellent resistance to both air and combustion gas oxidizing environments and can be used for long-term continuous exposure at temperatures up to $1150^{\circ} \mathrm{C}\left(2100^{\circ} \mathrm{F}\right)$. The measurement of metal loss and oxidation penetration at $2100^{\circ} \mathrm{F}, 200 \mathrm{~h}$, with $30 \mathrm{~min}$ cycles indicates that Haynes 230 performs better than alloy 617, while both $800 \mathrm{H}$ and SS 316 are consumed. Measurements of coupons exposed for four $24 \mathrm{~h}$ periods in $\mathrm{HCl}$ at $66^{\circ} \mathrm{C}$ show that the corrosion rate of this alloy is higher than that of alloy 625 , but lower than that of SS 316 . The alloy 
can be welded by a variety of techniques, including gas tungsten arc welding (GTAW), GMAW, and resistance welding.

\subsubsection{Potential MSR use and considerations}

Haynes 230 has been recognized as the long-term metal for high-temperature gas reactor (HTGR) application. It may be used in the reactor vessel and internals $[7,8]$.

The alloy is codified only for ASME BPVC Sections I, VIII, and XII and not for Section III. Thus, it is not qualified for use in the design of nuclear components like MSR systems. The corrosion of this alloy in either fluoride or chloride salts has been not investigated, and related data are very limited. The alloy is susceptible also to activation in an irradiation environment owing to the inclusion of cobalt (Co) in its composition.

Haynes 230 is used for a wide variety of component applications in the aerospace, power, and chemical process industries. However, no information from experience is available for this alloy in nuclear power plants.

\subsubsection{Haynes 242}

\subsubsection{Main features}

Haynes 242 alloy (UNS N10242) is an age-hardenable Ni-Mo-Cr alloy that derives its strength from a long-range ordering reaction upon aging [22]. The chemical composition as shown in Table 5 is similar to that of Hastelloy N. But it has more Mo and less iron than Hastelloy N does.

It has tensile and creep strength properties up to $705^{\circ} \mathrm{C}\left(1300^{\circ} \mathrm{F}\right)$ that are as much as double those of solid solution-strengthened alloys like Hastelloy $\mathrm{N}$, but with high ductility in the aged condition. The thermal expansion coefficients of Haynes 242 are much lower than those for most other alloys. This alloy has excellent strength and ductility as a cold-reduced and directly aged product. All these properties make Haynes 242 well suited for a range of fastener and bolting applications.

The alloy shows thermal stability in strength and ductility after exposure to $649^{\circ} \mathrm{C}\left(1200^{\circ} \mathrm{F}\right)$ for $8000 \mathrm{~h}$. This alloy also illustrates very good oxidation resistance up to $815^{\circ} \mathrm{C}\left(1500^{\circ} \mathrm{F}\right)$ and resistance fluorine and fluoride environments to $910^{\circ} \mathrm{C}\left(1670^{\circ} \mathrm{F}\right)$. The performance of Haynes 242 in these environments is comparable to but still lower than that of Hastelloy $\mathrm{N}$.

The alloy has very good forming and welding characteristics in the annealed condition. It may be forged or otherwise hot-worked by conventional techniques, and it is readily cold formable. Welding may be performed in the annealed condition by standard GTAW or GMAW techniques. Haynes 242 is furnished in the annealed condition and usually annealed in the range of 925$1120^{\circ} \mathrm{C}\left(1900-2050^{\circ} \mathrm{F}\right)$, depending upon specific requirements, followed by air cooling (or more rapid cooling) before aging. A water quench is recommended for heavy section components. Aging is performed at $650^{\circ} \mathrm{C}\left(1200^{\circ} \mathrm{F}\right)$ for a period of $24-48 \mathrm{~h}$, followed by air cooling. Haynes 242 is produced in the form of reforge billet, bar, plate, sheet, and wire welding products.

The alloy is codified for ASME BPVC Section VIII, Division 1. The approved material forms include plate, sheet, bar, forgings, fittings, welded pipe/tube, seamless pipe/tube. 


\subsubsection{Potential MSR use and considerations}

Haynes 242 is used as an alternative to Hastelloy $\mathrm{N}$ in the Idaho National Laboratory (INL) design of the secondary HXs for the Advanced High-Temperature Reactor (AHTR) [9]. It can be used for the construction of reactor vessels and piping.

The creep strength is limited because the alloy depends on solution strengthening at high temperatures. Its corrosion resistance in fluoride salt is comparable to but still inferior to that of Hastelloy N. The alloy contains $\mathrm{Co}$ and is subject to activation in an irradiation environment. It is codified only for ASME BPVC Section VIII and not for Section III, so Haynes 242 is not qualified to be used in the design of MSR components.

Haynes 242 combines properties that make it ideally suited for a variety of component applications in the aerospace industry. In the chemical process industry, it is used in hightemperature hydrofluoric acid vapor-containing processes as a consequence of its excellent resistance to that environment. The alloy displays excellent resistance to high-temperature fluoride salt mixtures. However, there is no experience with this alloy in nuclear power plants.

\subsection{Code Qualification}

Property data for structural materials in specific product forms for design and construction considerations are published in ASME BPVC Section II Part D and to some extent in Section III. If the components are intended for nuclear applications, the materials must be accepted into ASME BPVC Section III.

\subsubsection{Hastelloy $N$}

Currently, several product forms of this alloy-including welded pipes and tubing, seamless wrought pipes and tubing, fittings, plates, sheets, strips, and rods-are accepted in the BPVC and approved for bolting applications. The maximum codified design temperature for Hastelloy $\mathrm{N}$ is $704^{\circ} \mathrm{C}\left(1300^{\circ} \mathrm{F}\right)$, which is applicable to pressure vessels. Applications to bolting and transport tanks are limited to lower maximum permissible temperatures of $427^{\circ} \mathrm{C}\left(800^{\circ} \mathrm{F}\right)$ and $343^{\circ} \mathrm{C}$ $\left(650^{\circ} \mathrm{F}\right)$, respectively. A summary of the codification status for the alloy is given in Table 6 . The maximum allowable stress value $S$ and maximum allowable stress intensity value $S_{m}$ are provided in ASME BPVC Section II Part D, Table 1B, Table 3, and Table 5B.

For long-term time-dependent strength, comparison can be made with respect to 100,000-h creep strength at the temperature of interest. The maximum allowable stresses and stress intensity values of Hastelloy $\mathrm{N}$ and of several candidate materials for advanced nuclear reactors are compared in Figure 1 and Figure 2, respectively. The 100,000-h strength values are extracted from the allowable stresses of ASME BPVC Section II- D. At temperatures around $630^{\circ} \mathrm{C}$, Hastelloy $\mathrm{N}$ becomes weaker than other candidates like Haynes 230.

Again, although Hastelloy $\mathrm{N}$ was developed for nuclear applications and extensively investigated for nuclear reactor application during the MSRE program at ORNL, it has not been codified into ASME BPVC Section III-5. This means that the current qualification status of Hastelloy $\mathrm{N}$ does not allow it to be used for design and construction of any commercial nuclear reactors in the United States and Canada. 
Table 6 Codifica tion status of Hastelloy N (UNS N1003), based on ASME BPVC, 2017 edition . [23]

\begin{tabular}{|c|c|c|c|c|c|c|}
\hline Appl. & $\begin{array}{l}\text { Code } \\
\text { sect. }\end{array}$ & $\begin{array}{l}\text { Table } \\
\text { sect. }\end{array}$ & Table & Product & Max perm temp & $\begin{array}{c}\text { Allowable } \\
\text { design } \\
\text { stress type }\end{array}$ \\
\hline $\begin{array}{l}\text { Pressure } \\
\text { vessel }\end{array}$ & VIII-1 & II-D & Table 1B & $\begin{array}{l}\text { Fittings, plate, } \\
\text { sheet, strip, rod }\end{array}$ & $704^{\circ} \mathrm{C}\left(1300^{\circ} \mathrm{F}\right)$ & S \\
\hline $\begin{array}{l}\text { Transport } \\
\text { Tanks }\end{array}$ & XII & II-D & Table 1B & $\begin{array}{l}\text { Fittings, plate, } \\
\text { sheet, strip, rod }\end{array}$ & $343^{\circ} \mathrm{C}\left(650^{\circ} \mathrm{F}\right)$ & S \\
\hline $\begin{array}{l}\text { Pressure } \\
\text { Vessel }\end{array}$ & VIII-2 & II-D & Table 2B & $\begin{array}{l}\text { Plate, sheet, } \\
\text { strip, rod }\end{array}$ & $427^{\circ} \mathrm{C}\left(800^{\circ} \mathrm{F}\right)$ & $\mathrm{S}_{\mathrm{m}}$ \\
\hline $\begin{array}{l}\text { Pressure } \\
\text { Vessel }\end{array}$ & VIII-1 & II-D & Table 3 & Bolting & $704^{\circ} \mathrm{C}\left(1300^{\circ} \mathrm{F}\right)$ & S \\
\hline $\begin{array}{l}\text { Pressure } \\
\text { Vessel }\end{array}$ & VIII-2 & II-D & Table 3 & Bolting & $427^{\circ} \mathrm{C}\left(800^{\circ} \mathrm{F}\right)$ & S \\
\hline $\begin{array}{l}\text { Transport } \\
\text { Tanks }\end{array}$ & XII & II-D & Table 3 & Bolting & $343^{\circ} \mathrm{C}\left(650^{\circ} \mathrm{F}\right)$ & S \\
\hline $\begin{array}{l}\text { Pressure } \\
\text { Vessel }\end{array}$ & VIII-2 & II-D & Table 5B & $\begin{array}{l}\text { Plate, sheet, } \\
\text { strip, rod }\end{array}$ & $427^{\circ} \mathrm{C}\left(800^{\circ} \mathrm{F}\right)$ & S \\
\hline
\end{tabular}

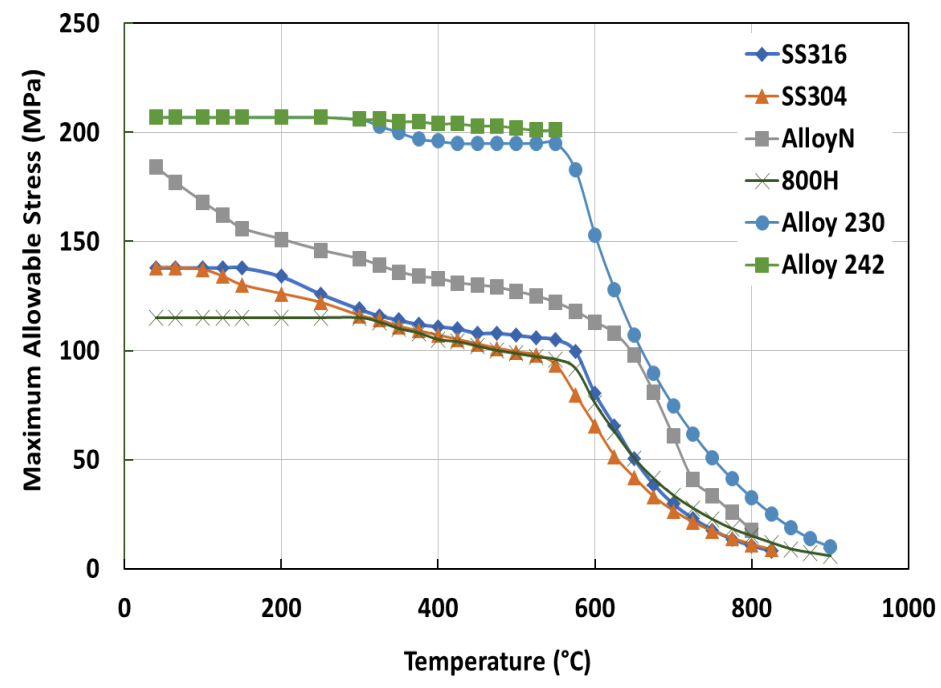

Figure 1 Comparison of the allowable stresses (S) based on $100,000 \mathrm{~h}$ for candidate materials considered for service at temperature up to $900{ }^{\circ} \mathrm{C}$. 


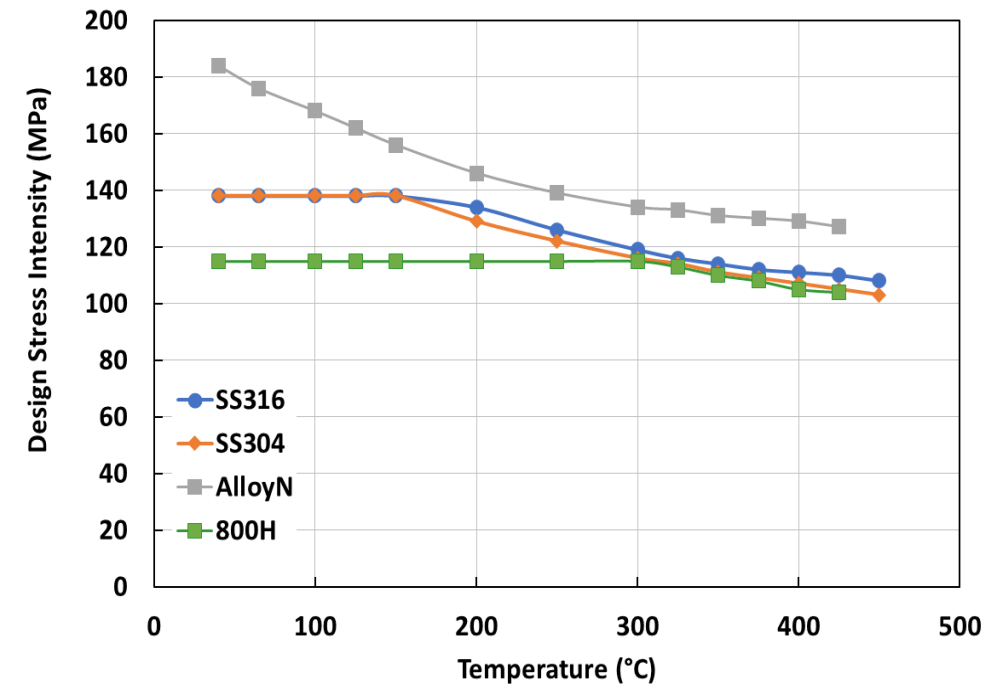

Figure 2 Comparison of the stress intensity $(\mathrm{S} \mathrm{m})$ values for candidate materials considered for service at temperature up to $450^{\circ} \mathrm{C}$.

\subsubsection{Incoloy $80 \mathrm{OH}$, SSs 304, 316, Haynes 230, and Haynes 242}

Incoloy $800 \mathrm{H}$ is approved for the ASME BPVC, including Section I, Rules for Construction of Power Boilers; Section VIII, Rules for Construction of Pressure Vessels, Divisions 1 (15 psi max. pressure) and 2 (3,000 psi max. pressure); Section XII, Rules for Construction and Continued Service of Transport Tanks; and Section III, Rules for Construction of Nuclear Facility Components, Division 5 High Temperature Reactors. Incoloy $800 \mathrm{H}$ is approved in various forms of products. The allowable stresses for design are listed in related tables in ASME BPVC Section II-D and Section III-5 with the respective permit temperatures. Code status is summarized in Table 7.

Codifications of SS 304 and SS 316, based on ASME BPVC, 2017 Edition, are summarized in Table 8 and Table 9, respectively. Herein, S30400 and S30409 are the focus of SS 304, as the two steels are either baseline or have high carbon content for high-temperature applications. The same consideration is given to the code status, Table 9, for SS316. If the permit temperatures are considered, it is apparent that these temperatures are similar for the two SSs. However, their allowable stresses are different, as can be seen in Figure 1 and Figure 2. 
Table 7 Incoloy $800 \mathrm{H}$ code status ( UNS N08810) based on ASME BPVC, 2017 edition. $[23,24]$

\begin{tabular}{|c|c|c|c|c|c|c|}
\hline Appl. & $\begin{array}{l}\text { Code } \\
\text { sect. }\end{array}$ & $\begin{array}{l}\text { Table } \\
\text { sect. }\end{array}$ & Table & Product & $\begin{array}{l}\text { Max perm } \\
\text { temp }\end{array}$ & $\begin{array}{c}\text { Allowable } \\
\text { design stress } \\
\text { type }\end{array}$ \\
\hline Power boilers & 1 & II-D & Table 1B & Various forms & $\begin{array}{l}816^{\circ} \mathrm{C} \\
\left(1500^{\circ} \mathrm{F}\right)\end{array}$ & $S$ \\
\hline $\begin{array}{l}\text { Nuclear facility } \\
\text { components }\end{array}$ & III-1 & II-D & Table 1B & Various forms & $427^{\circ} \mathrm{C}\left(800^{\circ} \mathrm{F}\right)$ & $S$ \\
\hline $\begin{array}{l}\text { Pressure } \\
\text { vessels }\end{array}$ & VIII-1 & II-D & Table 1B & Various forms & $\begin{array}{l}899^{\circ} \mathrm{C}, 982^{\circ} \mathrm{C} \\
\left(1650^{\circ} \mathrm{F}\right. \\
\left.1800^{\circ} \mathrm{F}\right)^{*}\end{array}$ & $S$ \\
\hline $\begin{array}{l}\text { Nuclear facility } \\
\text { components }\end{array}$ & III-1 & II-D & $\begin{array}{l}\text { Table } \\
2 \mathrm{~B}\end{array}$ & Various forms & $427^{\circ} \mathrm{C}\left(800^{\circ} \mathrm{F}\right)$ & $\mathrm{S}_{\mathrm{m}}$ \\
\hline $\begin{array}{l}\text { Pressure } \\
\text { vessels }\end{array}$ & VIII-2 & II-D & $\begin{array}{l}\text { Table } \\
2 \mathrm{~B}\end{array}$ & Various forms & $427^{\circ} \mathrm{C}\left(800^{\circ} \mathrm{F}\right)$ & $\mathrm{S}_{\mathrm{m}}$ \\
\hline $\begin{array}{l}\text { Pressure } \\
\text { vessels }\end{array}$ & VIII-1 & II-D & Table 3 & Bolting & $\begin{array}{l}899^{\circ} \mathrm{C} \\
\left(1650^{\circ} \mathrm{F}\right)\end{array}$ & S \\
\hline $\begin{array}{l}\text { Pressure } \\
\text { vessels }\end{array}$ & VIII-2 & II-D & Table 3 & Bolting & $427^{\circ} \mathrm{C}\left(800^{\circ} \mathrm{F}\right)$ & $S$ \\
\hline $\begin{array}{l}\text { Transport } \\
\text { tanks }\end{array}$ & XII & II-D & Table 3 & Bolting & $343^{\circ} \mathrm{C}\left(650^{\circ} \mathrm{F}\right)$ & $S$ \\
\hline $\begin{array}{l}\text { Pressure } \\
\text { vessels }\end{array}$ & VIII-2 & II-D & $\begin{array}{l}\text { Table } \\
5 B\end{array}$ & Various forms & $\begin{array}{l}899^{\circ} \mathrm{C} \\
\left(1650^{\circ} \mathrm{F}\right)\end{array}$ & $S$ \\
\hline $\begin{array}{l}\text { Nuclear facility } \\
\text { components }\end{array}$ & III-5 & III-5 & $\begin{array}{l}\text { Table } \\
\text { HBB-I- } \\
14.2\end{array}$ & Various forms & $\begin{array}{l}760^{\circ} \mathrm{C} \\
\left(1400^{\circ} \mathrm{F}\right)^{\star *}\end{array}$ & $\mathrm{~S}_{0}$ \\
\hline $\begin{array}{l}\text { Nuclear facility } \\
\text { components }\end{array}$ & III-5 & III-5 & $\begin{array}{l}\text { Table } \\
\text { HBB-I- } \\
14.3 \mathrm{C}\end{array}$ & Various forms & $\begin{array}{l}760^{\circ} \mathrm{C} \\
\left(1400^{\circ} \mathrm{F}\right)^{* *}\end{array}$ & $S_{m t}$ \\
\hline $\begin{array}{l}\text { Nuclear facility } \\
\text { components }\end{array}$ & III-5 & III-5 & $\begin{array}{l}\text { Table } \\
\text { HBB-I- } \\
14.4 C\end{array}$ & Various forms & $\begin{array}{l}760^{\circ} \mathrm{C} \\
\left(1400^{\circ} \mathrm{F}\right)^{\star *}\end{array}$ & $S_{t}$ \\
\hline $\begin{array}{l}\text { Nuclear facility } \\
\text { components }\end{array}$ & III-5 & III-5 & $\begin{array}{l}\text { Table } \\
\text { HCB-II- } \\
2000-4\end{array}$ & Various forms & $\begin{array}{l}704^{\circ} \mathrm{C} \\
\left(1300^{\circ} \mathrm{F}\right)^{\star *}\end{array}$ & $S$ \\
\hline $\begin{array}{l}\text { Nuclear facility } \\
\text { components }\end{array}$ & III-5 & III-5 & $\begin{array}{l}\text { Table } \\
\text { HCB-II- } \\
3000-4\end{array}$ & Various forms & $\begin{array}{l}899^{\circ} \mathrm{C}, 982^{\circ} \mathrm{C} \\
\left(1650^{\circ} \mathrm{F}\right. \\
\left.1800^{\circ} \mathrm{F}\right)^{\star *}\end{array}$ & $S$ \\
\hline $\begin{array}{l}\text { Nuclear facility } \\
\text { components }\end{array}$ & III-5 & III-5 & $\begin{array}{l}\text { Table } \\
\text { HGB-II- } \\
2121-3\end{array}$ & Various forms & $\begin{array}{l}649^{\circ} \mathrm{C} \\
\left(1200^{\circ} \mathrm{F}\right)^{\star *}\end{array}$ & $S_{m}$ \\
\hline
\end{tabular}

*Seamless. pipe and tube; ${ }^{* *} \max$ temperature listed. 
Table 8 SS 304 code status (UNS S30400, S30409) based on ASME BPVC, 2017 edition . $[23,24]$

\begin{tabular}{|c|c|c|c|c|c|c|}
\hline Appl. & $\begin{array}{l}\text { Code } \\
\text { sect. }\end{array}$ & $\begin{array}{l}\text { Table } \\
\text { sect. }\end{array}$ & Table & Product & $\begin{array}{l}\text { Max perm } \\
\text { temp }\left({ }^{\circ} F\right)\end{array}$ & $\begin{array}{c}\text { Allowable } \\
\text { design stress } \\
\text { type }\end{array}$ \\
\hline Power boilers & 1 & II-D & Table 1A & $\begin{array}{l}\text { Various } \\
\text { forms }\end{array}$ & 1500 & $S$ \\
\hline $\begin{array}{l}\text { Nuclear } \\
\text { facility } \\
\text { components }\end{array}$ & III-1 & II-D & Table 1A & $\begin{array}{l}\text { Various } \\
\text { forms }\end{array}$ & 800 & $S$ \\
\hline $\begin{array}{l}\text { Pressure } \\
\text { vessels }\end{array}$ & VIII-1 & II-D & Table 1A & $\begin{array}{l}\text { Various } \\
\text { forms }\end{array}$ & 1500 & S \\
\hline $\begin{array}{l}\text { Transport } \\
\text { tanks }\end{array}$ & XII & $\|-D$ & Table 1A & $\begin{array}{l}\text { Various } \\
\text { forms }\end{array}$ & 650 & $S$ \\
\hline $\begin{array}{l}\text { Nuclear } \\
\text { facility } \\
\text { components }\end{array}$ & III-1 & II-D & Table 2A & $\begin{array}{l}\text { Various } \\
\text { forms }\end{array}$ & 800 & $\mathrm{~S}_{\mathrm{m}}$ \\
\hline $\begin{array}{l}\text { Pressure } \\
\text { vessels }\end{array}$ & VIII-2 & II-D & Table 2A & $\begin{array}{l}\text { Various } \\
\text { forms }\end{array}$ & 800 & $S_{m}$ \\
\hline $\begin{array}{l}\text { Nuclear facility } \\
\text { components }\end{array}$ & III-1 & II-D & Table $3^{*}$ & Bolting & 800 & $S$ \\
\hline $\begin{array}{l}\text { Pressure } \\
\text { vessels }\end{array}$ & VIII-1 & II-D & Table 3* & Bolting & 1500 & $S$ \\
\hline $\begin{array}{l}\text { Pressure } \\
\text { vessels }\end{array}$ & VIII-2 & II-D & Table $3^{*}$ & Bolting & 800 & $\mathrm{~S}$ \\
\hline $\begin{array}{l}\text { Transport } \\
\text { tanks }\end{array}$ & XII & II-D & Table $3^{*}$ & Bolting & 650 & $S$ \\
\hline $\begin{array}{l}\text { Nuclear facility } \\
\text { components }\end{array}$ & III-1 & II-D & Table $4^{*}$ & Bolting & 800 & $S_{m}$ \\
\hline $\begin{array}{l}\text { Pressure } \\
\text { vessels }\end{array}$ & VIII-2 & II-D & Table $4^{*}$ & Bolting & 800 & $S_{m}$ \\
\hline $\begin{array}{l}\text { Pressure } \\
\text { vessels }\end{array}$ & VIII-2 & II-D & Table 5A & $\begin{array}{l}\text { Various } \\
\text { forms }\end{array}$ & 1500 & S \\
\hline $\begin{array}{l}\text { Nuclear } \\
\text { facility } \\
\text { components }\end{array}$ & III-5 & III-5 & $\begin{array}{l}\text { Table } \\
\text { HBB-I- } \\
14.2\end{array}$ & $\begin{array}{l}\text { Various } \\
\text { forms }\end{array}$ & $1500^{* *}$ & $\mathrm{~S}_{0}$ \\
\hline
\end{tabular}


Table 8 SS 304 code status (UNS S30400, S30409)(continued)

\begin{tabular}{|c|c|c|c|c|c|c|}
\hline Appl. & $\begin{array}{l}\text { Code } \\
\text { sect. }\end{array}$ & $\begin{array}{l}\text { Table } \\
\text { sect. }\end{array}$ & Table & Product & $\begin{array}{l}\text { Max perm } \\
\left.\text { temp ( }{ }^{\circ} \mathrm{F}\right)\end{array}$ & $\begin{array}{c}\text { Allowable } \\
\text { design stress } \\
\text { type }\end{array}$ \\
\hline $\begin{array}{l}\text { Nuclear } \\
\text { facility } \\
\text { components }\end{array}$ & III-5 & III-5 & $\begin{array}{l}\text { Table } \\
\text { HBB-I- } \\
14.3 \mathrm{~A}\end{array}$ & $\begin{array}{l}\text { Various } \\
\text { forms }\end{array}$ & $1500^{* *}$ & $\mathrm{~S}_{\mathrm{mt}}$ \\
\hline $\begin{array}{l}\text { Nuclear } \\
\text { facility } \\
\text { components }\end{array}$ & III-5 & III-5 & $\begin{array}{l}\text { Table } \\
\text { HBB-I- } \\
14.4 \mathrm{~A}\end{array}$ & $\begin{array}{l}\text { Various } \\
\text { forms }\end{array}$ & $1500^{* *}$ & $S_{t}$ \\
\hline $\begin{array}{l}\text { Nuclear } \\
\text { facility } \\
\text { components }\end{array}$ & III-5 & III-5 & $\begin{array}{l}\text { Table } \\
\text { HCB-II- } \\
2000-3\end{array}$ & $\begin{array}{l}\text { Various } \\
\text { forms }\end{array}$ & $1500^{* *}$ & $S$ \\
\hline $\begin{array}{l}\text { Nuclear } \\
\text { facility } \\
\text { components }\end{array}$ & III-5 & III-5 & $\begin{array}{l}\text { Table } \\
\text { HCB-II- } \\
3000-3\end{array}$ & $\begin{array}{l}\text { Various } \\
\text { forms }\end{array}$ & $1500^{* *}$ & $S$ \\
\hline $\begin{array}{l}\text { Nuclear } \\
\text { facility } \\
\text { components }\end{array}$ & III-5 & III-5 & $\begin{array}{l}\text { Table } \\
\text { HGB-II- } \\
2121-3\end{array}$ & $\begin{array}{l}\text { Various } \\
\text { forms }\end{array}$ & $1000^{* *}$ & $S_{m}$ \\
\hline
\end{tabular}

*Only for UNS S30400; **max temperature listed.

Table 9 SS 316 code status (UNS S31600, S31609) based on ASME BPVC, 2017 edition . $[23,24]$

\begin{tabular}{|c|c|c|c|c|c|c|}
\hline Appl. & $\begin{array}{l}\text { Code } \\
\text { sect. }\end{array}$ & $\begin{array}{l}\text { Table } \\
\text { sect. }\end{array}$ & Table & Product & $\begin{array}{l}\text { Max perm } \\
\text { temp }\left({ }^{\circ} F\right)\end{array}$ & $\begin{array}{c}\text { Allowable } \\
\text { design stress } \\
\text { type }\end{array}$ \\
\hline Power boilers & I & II-D & Table 1A & $\begin{array}{l}\text { Various } \\
\text { forms }\end{array}$ & 1500 & $S$ \\
\hline $\begin{array}{l}\text { Nuclear } \\
\text { facility } \\
\text { components }\end{array}$ & III-1 & II-D & Table 1A & $\begin{array}{l}\text { Various } \\
\text { forms }\end{array}$ & 800 & $S$ \\
\hline $\begin{array}{l}\text { Pressure } \\
\text { vessels }\end{array}$ & VIII-1 & II-D & Table 1A & $\begin{array}{l}\text { Various } \\
\text { forms }\end{array}$ & 1500 & $S$ \\
\hline $\begin{array}{l}\text { Transport } \\
\text { tanks }\end{array}$ & XII & II-D & Table 1A & $\begin{array}{l}\text { Various } \\
\text { forms }\end{array}$ & 650 & S \\
\hline $\begin{array}{l}\text { Nuclear } \\
\text { facility } \\
\text { components }\end{array}$ & III-1 & II-D & Table 2A & $\begin{array}{l}\text { Various } \\
\text { forms }\end{array}$ & 800 & $S_{m}$ \\
\hline
\end{tabular}


Table 9 SS 316 code status (UNS S31600, S31609)(continued)

\begin{tabular}{|c|c|c|c|c|c|c|}
\hline Appl. & $\begin{array}{l}\text { Code } \\
\text { sect. }\end{array}$ & $\begin{array}{l}\text { Table } \\
\text { sect. }\end{array}$ & Table & Product & $\begin{array}{l}\text { Max perm } \\
\left.\text { temp ( }{ }^{\circ} \mathrm{F}\right)\end{array}$ & $\begin{array}{c}\text { Allowable } \\
\text { design stress } \\
\text { type }\end{array}$ \\
\hline $\begin{array}{l}\text { Pressure } \\
\text { vessels }\end{array}$ & VIII-2 & II-D & Table 2A & $\begin{array}{l}\text { Various } \\
\text { forms }\end{array}$ & 800 & $S_{m}$ \\
\hline $\begin{array}{l}\text { Nuclear facility } \\
\text { components }\end{array}$ & III-1 & II-D & Table $3^{*}$ & Bolting & 800 & $S$ \\
\hline $\begin{array}{l}\text { Pressure } \\
\text { vessels }\end{array}$ & VIII-1 & II-D & Table $3^{*}$ & Bolting & 1500 & $S$ \\
\hline $\begin{array}{l}\text { Pressure } \\
\text { vessels }\end{array}$ & VIII-2 & II-D & Table $3^{*}$ & Bolting & 800 & $S$ \\
\hline $\begin{array}{l}\text { Transport } \\
\text { tanks }\end{array}$ & XII & II-D & Table $3^{*}$ & Bolting & 650 & $S$ \\
\hline $\begin{array}{l}\text { Nuclear facility } \\
\text { components }\end{array}$ & III-1 & II-D & Table $4^{*}$ & Bolting & 800 & $S_{m}$ \\
\hline $\begin{array}{l}\text { Pressure } \\
\text { vessels }\end{array}$ & VIII-2 & II-D & Table $4^{*}$ & Bolting & 800 & $S_{m}$ \\
\hline $\begin{array}{l}\text { Pressure } \\
\text { vessels }\end{array}$ & VIII-2 & II-D & Table 5A & $\begin{array}{l}\text { Various } \\
\text { forms }\end{array}$ & 1500 & $S$ \\
\hline $\begin{array}{l}\text { Nuclear } \\
\text { facility } \\
\text { components }\end{array}$ & III-5 & III-5 & $\begin{array}{l}\text { Table } \\
\text { HBB-I- } \\
14.2\end{array}$ & $\begin{array}{l}\text { Various } \\
\text { forms }\end{array}$ & $1500^{* *}$ & $\mathrm{~S}_{0}$ \\
\hline $\begin{array}{l}\text { Nuclear } \\
\text { facility } \\
\text { components }\end{array}$ & III-5 & III-5 & $\begin{array}{l}\text { Table } \\
\text { HBB-I- } \\
14.3 B\end{array}$ & $\begin{array}{l}\text { Various } \\
\text { forms }\end{array}$ & $1500^{* *}$ & $S_{m t}$ \\
\hline $\begin{array}{l}\text { Nuclear } \\
\text { facility } \\
\text { components }\end{array}$ & III-5 & III-5 & $\begin{array}{l}\text { Table } \\
\text { HBB-I- } \\
14.4 \mathrm{~B}\end{array}$ & $\begin{array}{l}\text { Various } \\
\text { forms }\end{array}$ & $1500^{* *}$ & $S_{t}$ \\
\hline $\begin{array}{l}\text { Nuclear } \\
\text { facility } \\
\text { components }\end{array}$ & III-5 & III-5 & $\begin{array}{l}\text { Table } \\
\text { HCB-II- } \\
2000-3\end{array}$ & $\begin{array}{l}\text { Various } \\
\text { forms }\end{array}$ & $1200^{* *}$ & $S$ \\
\hline $\begin{array}{l}\text { Nuclear } \\
\text { facility } \\
\text { components }\end{array}$ & III-5 & III-5 & $\begin{array}{l}\text { Table } \\
\text { HCB-II- } \\
3000-3\end{array}$ & $\begin{array}{l}\text { Various } \\
\text { forms }\end{array}$ & $1500^{* *}$ & $S$ \\
\hline $\begin{array}{l}\text { Nuclear } \\
\text { facility } \\
\text { components }\end{array}$ & III-5 & III-5 & $\begin{array}{l}\text { Table } \\
\text { HGB-II- } \\
2121-3\end{array}$ & $\begin{array}{l}\text { Various } \\
\text { forms }\end{array}$ & $1100^{* *}$ & $S_{m}$ \\
\hline
\end{tabular}

*Only for UNS S31600; **max temperature listed. 
Codifications of Haynes 230 and 242 are summarized in Table 10 and Table 11, respectively. The two alloys are approved only for limited sections, especially Haynes 242 . If Haynes 242 is considered as a candidate alloy for MSRs in the future, a code case effort will need to be made to include this alloy in ASME BPVC Section III-5.

Table 10 Haynes 230 code status (UNS N06230), based on ASME BPVC, 2017 edition . [23]

\begin{tabular}{|c|c|c|c|c|c|c|}
\hline Appl. & $\begin{array}{l}\text { Code } \\
\text { sect. }\end{array}$ & $\begin{array}{l}\text { Table } \\
\text { sect. }\end{array}$ & Table & Product & $\begin{array}{l}\text { Max perm } \\
\left.\text { temp ( }{ }^{\circ} \mathrm{F}\right)\end{array}$ & $\begin{array}{c}\text { Allowable } \\
\text { design stress } \\
\text { type }\end{array}$ \\
\hline Power boilers & I & II-D & Table 1B & Various forms & 1650 & $S$ \\
\hline $\begin{array}{l}\text { Pressure } \\
\text { vessels }\end{array}$ & VIII-1 & II-D & Table 1B & Various forms & 1800 & $S$ \\
\hline $\begin{array}{l}\text { Transport } \\
\text { tanks }\end{array}$ & XII & II-D & Table 1B & Various forms & 650 & $S$ \\
\hline
\end{tabular}

Table 11 Haynes 242 code status (UNS N10242), based on ASME BPVC, 2017 edition . [23]

\begin{tabular}{|llllllll|}
\hline \multicolumn{1}{|c}{ Appl. } & $\begin{array}{l}\text { Code } \\
\text { sect. }\end{array}$ & $\begin{array}{c}\text { Table } \\
\text { sect. }\end{array}$ & Table & Product & $\begin{array}{c}\text { Max perm } \\
\text { temp ( }{ }^{\circ} \text { F) }\end{array}$ & $\begin{array}{c}\text { Allowable } \\
\text { design stress } \\
\text { type }\end{array}$ \\
\hline $\begin{array}{l}\text { Pressure } \\
\text { vessels }\end{array}$ & VIII-1 & II-D & Table 1B & Various forms & 1000 & $\mathrm{~S}$ \\
\hline
\end{tabular}

\subsubsection{Summary and suggestions}

In general, the codified metallic materials-including Incoloy $800 \mathrm{H}$, SS 304, and SS 316-in ASME BPVC Section III-5 can provide the mechanical strength required in high temperatures. However, all of them are subjected to $\mathrm{Cr}$ depletion in fluoride molten salt because of the large $\mathrm{Cr}$ content in their chemical compositions. A protective liner like Hastelloy $N$ is needed in the structural design. Several options exist regarding the application of Hastelloy $\mathrm{N}$, including welded-on liners. However, there is currently a lack of an ASME code case for welded-on liners.

The inclusion of Hastelloy N in ASME BPVC Section III-5 represents one of the feasible technical approaches to addressing the immediate challenge regarding the availability of alloys for MSR designs. This is reasonable because of the relatively large database established and extensive experience obtained during the MSRE project at ORNL. The subsequent review thus focuses more on the previous work conducted on this alloy. 


\subsection{Creep Resistance}

\subsubsection{Review}

A list of heats of Hastelloy $N$ that were tested in creep rupture in the 1950s and 1960s is provided in Table 12. The product forms covered sheet, bar, and plate. Melting practices included air and vacuum-arc re-melted. The chemical composition of the heats is given in Table 13 according to Swindeman [11].

The first report of creep and stress-rupture properties was published by Schultz for heat 8284 [25]. Relatively short-time stress-rupture tests were performed at $1100,1300,1500$, and $1700^{\circ} \mathrm{F}$.

Table 12 Heats and product forms of Hastelloy $-\mathrm{N}$ tested in creep rupture by different groups.

\begin{tabular}{|c|c|c|c|c|c|c|}
\hline Heat ID* & Producer & $\begin{array}{l}\text { Product } \\
\text { forms }\end{array}$ & $\begin{array}{c}\text { Heat } \\
\text { treatment, } \\
{ }^{\circ} F\end{array}$ & $\begin{array}{c}\text { Heat } \\
\text { treatment, } \\
{ }^{\circ} \mathrm{C}\end{array}$ & $\begin{array}{l}\text { ASTM grain } \\
\text { size number }\end{array}$ & Reference \\
\hline 5055 & Haynes & Plate & 2150 & 1177 & - & [28] \\
\hline 5075 & Haynes & Plate & 2150 & 1177 & - & [28] \\
\hline 5081 & Haynes & Plate & 2150 & 1177 & - & [28] \\
\hline 5085 & Haynes & Plate & 2150 & 1177 & & [29] \\
\hline SP-16 & Haynes & $\begin{array}{l}\text { Bar \& } \\
\text { Sheet }\end{array}$ & $2000 \& 2100$ & $1093 \& 1149$ & $2-4$ & [26] \\
\hline 8284 & Haynes & Sheet & 2150 & 1260 & & [25] \\
\hline SP-19 & Haynes & $\begin{array}{l}\text { Bar \& } \\
\text { Sheet }\end{array}$ & 2100 & 1149 & $1-3,5-7$ & [26] \\
\hline M-1566 & Westinghouse & $\begin{array}{l}\text { Bar \& } \\
\text { Sheet }\end{array}$ & 2100 & 1149 & $5-7$ & [26] \\
\hline $8 M-1$ & Westinghouse & Sheet & 2100 & 1149 & $5-7$ & [26] \\
\hline 1327 & Westinghouse & Sheet & 2100 & 1149 & $5-7$ & [26] \\
\hline 5065 & Haynes & Plate & 2150 & 1177 & & [29] \\
\hline 5911 & Allvac & Bar & $2150^{* *}$ & 1177 & & [33] \\
\hline 6252 & Allvac & Bar & $2150^{* *}$ & 1177 & & [33] \\
\hline 5050 & Haynes & Bar & 2300 & 1260 & & {$[45]$} \\
\hline
\end{tabular}

*Based on Swindeman [11].

${ }^{* *}$ Several other heat treatments. 
Table 13 Chemical composition of heats of Hastelloy N, wt \%.

\begin{tabular}{|c|c|c|c|c|c|c|c|c|c|c|c|c|c|c|c|}
\hline $\begin{array}{l}\text { Heat } \\
\text { ID* }\end{array}$ & Mo & Cr & Fe & C & Mn & Si & W & Al & Ti & Cu & Co & $\mathbf{P}$ & $\mathbf{S}$ & B & V \\
\hline 5055 & 16.2 & 7.86 & 3.76 & 0.06 & 0.69 & 0.61 & 0.03 & 0.06 & 0.02 & $<0.01$ & 0.1 & 0.006 & 0.008 & 0.005 & 0.21 \\
\hline 5075 & 16.14 & 6.76 & 4.03 & 0.06 & 0.42 & 0.59 & 0.04 & 0.01 & 0.01 & $<0.01$ & 0.08 & 0.003 & 0.007 & 0.001 & 0.28 \\
\hline 5081 & 16.87 & 7.43 & 3.35 & 0.07 & 0.55 & 0.6 & 0.03 & 0.01 & 0.01 & 0.02 & 0.07 & 0.001 & 0.006 & 0.004 & 0.26 \\
\hline $5081-2$ & 16.4 & 6.1 & 3.4 & 0.059 & 0.65 & 0.52 & 0.07 & 0.05 & 0.01 & $<0.01$ & 0.1 & 0.012 & 0.002 & 0.005 & 0.2 \\
\hline 5085 & 16.3 & 6.2 & 3.3 & 0.054 & 0.67 & 0.58 & 0.07 & 0.02 & 0.01 & $<0.01$ & 0.15 & 0.013 & 0.004 & 0.0038 & 0.2 \\
\hline SP-16 & 15.82 & 6.99 & 4.85 & 0.02 & 0.34 & 0.32 & 0.35 & & & & & & & 0.02 & \\
\hline 8284 & 15.8 & 7.1 & 4.1 & 0.03 & 0.55 & 0.42 & & & & & & & & & \\
\hline SP-19-1 & 16.65 & 7.43 & 4.83 & 0.06 & 0.48 & 0.04 & & & & 0.02 & 0.51 & 0.01 & 0.015 & & \\
\hline M-1566 & 16.1 & 7.9 & 4.2 & 0.08 & 0.66 & 0.2 & & & 0.08 & & & 0.002 & 0.004 & & \\
\hline $8 \mathrm{M}-1$ & 16.2 & 7.47 & 6.1 & 0.14 & 0.69 & 0.21 & & 0.08 & & & & 0.009 & 0.006 & & \\
\hline 1327 & 17.2 & 7 & 5.1 & 0.14 & 0.73 & 0.19 & & 0.07 & & & & $<0.01$ & $<0.01$ & & \\
\hline 5065 & 16.5 & 7.2 & 3.9 & 0.065 & 0.55 & 0.6 & 0.04 & 0.01 & 0.01 & $<0.01$ & 0.08 & 0.004 & 0.007 & & 0.22 \\
\hline 5911 & 17.01 & 6.14 & 0.03 & 0.056 & 0.21 & 0.05 & & 0.15 & 0.067 & $<0.01$ & 0.08 & 0.05 & 0.002 & 0.001 & \\
\hline 6252 & 16.53 & 7.26 & 0.12 & 0.051 & 0.2 & 0.05 & & 0.2 & 0.13 & $<0.01$ & 0.11 & 0.05 & 0.002 & 0.0003 & \\
\hline \multicolumn{16}{|l|}{5050} \\
\hline Spec & $\begin{array}{l}15 \text { to } \\
19\end{array}$ & 6 to 8 & $\begin{array}{l}5 \\
\max \end{array}$ & $\begin{array}{l}0.04 \\
\text { to } \\
0.08\end{array}$ & $\begin{array}{l}0.8 \\
\max \end{array}$ & $\begin{array}{l}0.55 \\
\max \end{array}$ & $\begin{array}{l}0.50 \\
\max \end{array}$ & $\begin{array}{l}0.50 \\
\max \end{array}$ & & $\begin{array}{l}0.50 \\
\max \end{array}$ & $\begin{array}{l}0.2 \\
\max \end{array}$ & $\begin{array}{l}0.01 \\
\max \end{array}$ & $\begin{array}{l}0.01 \\
\max \end{array}$ & $\begin{array}{l}0.01 \\
\max \end{array}$ & \\
\hline
\end{tabular}

${ }^{*}$ Based on Swindeman [11].

The second source of creep and stress-rupture data was a report by Swindeman in 1961 [26]. Both 0.063-in.-thick sheet and 0.505-in. rod specimens were tested. Specimens were annealed at both 2000 and $2100^{\circ} \mathrm{F}$. Testing of sheet samples was performed in equipment described by Manly and Douglas [27]. Tests included both air and static molten salt environments. Testing of bar samples in air was performed in a 6,000-lb lever-arm Arcweld machine equipped with extensometers. Testing in molten salt was carried out in a chamber constructed of Inconel 600, Hastelloy B, or Hastelloy $C$. The nominal composition of the molten salt in terms of mole percent was NaF-11.2, KF-41, LiF-45.3, and $\mathrm{UF}_{4-}$ 2.5. Extension measurements were obtained from a dial gage that recorded the upward travel of the pull rod on the exterior of the testing chamber.

Temperatures ranged from 1100 to $1800^{\circ} \mathrm{F}$, and times extended to $20,000 \mathrm{~h}$ in some cases. Most of the tests in salt focused on 1100,1200 , and $1300^{\circ} \mathrm{F}$, but only a few were conducted at 1500 , 1650 , and $1800^{\circ} \mathrm{F}$ each. This is perhaps because $1300^{\circ} \mathrm{F}$ was considered as the potential operational temperature of MSR and the alloy tested extensively at that temperature and below.

Test results in salt: Scatter bands have been drawn to cover the data corresponding to various temperatures in a plot of the stress vs. rupture life. At 1100,1200 , and $1300^{\circ} \mathrm{F}$, the bands are nearly parallel, while the slopes at 1650 and $1800^{\circ} \mathrm{F}$ apparently depend on stress or temperature. Plots of the stress vs. the minimum creep rate exhibit the same characteristics except that (1) the 
scatter band for $1100^{\circ} \mathrm{F}$ data is not parallel to those at 1200 and $1300^{\circ} \mathrm{F}$ and (2) the data at $1500^{\circ} \mathrm{F}$ and above show greater temperature dependency. Several creep tests on specimens aged $50 \mathrm{~h}$ at $1300^{\circ} \mathrm{F}$ have been performed in salt at 1200,1500 , and $1800^{\circ} \mathrm{F}$. Data do not indicate any significant aging effect. Several observations can be made:

- Ductilities are greater at the higher temperatures, but the rupture lives corresponding to those ductilities are short. The maximum value reported is $22 \%$ for heat 1327 at $1800^{\circ} \mathrm{F}$ after $23 \mathrm{~h}$.

- For various heats tested in salt at $1300^{\circ} \mathrm{F}$ and $20,000 \mathrm{psi}$, fracture occurs by intergranular cracking. At 1100 and $1200^{\circ} \mathrm{F}$, there are indications that the creep strength improves with increasing carbon and decreasing grain size. At $1300^{\circ} \mathrm{F}$, the grain size has not affected the rupture life. It is possible that $1300^{\circ} \mathrm{F}$ is a transition temperature above which the coarse-grained SP 16 is stronger than the fine-grained heats.

- Precipitate forms at all temperatures and becomes coarser and more evident as the temperature and time increase. Carbide precipitation could also play a role in creep. The slight contraction, sometimes observed in SP 16 during the initial period of creep or relaxation tests, might be explained by assuming a volume contraction associated with precipitation. The continually decreasing strain rates in SP 16 for low stresses at $1500^{\circ} \mathrm{F}$ and above might be explained by the strengthening produced through the precipitation and coarsening of the carbides along the grain boundaries.

Test results in air: The test data at $1250^{\circ} \mathrm{F}$ indicate a break in the plot of stress vs. the rupture life near the yield strength. The creep ductilities for tests in air are low, and values range from $2.7 \%$ at $1200^{\circ} \mathrm{F}$ to $14.5 \%$ at $1700^{\circ} \mathrm{F}$. Many of the failures in sheet specimens were under the knife edge of the extensometer clamp. The elongation seemed not to be developed well because of the notch failure.

Three heats of commercial plate products were evaluated by Venard and the results were reported in 1965 [28]. Test specimens were taken from heats 5055, 5075, and 5081 in both the rolling and transverse directions. Specimens were threaded-end bars with 0.276 -in.-diameter gage sections. All testing was in air in Arcweld lever arm creep machines equipped with extensometers. Temperatures were 1100,1300 , and $1500^{\circ} \mathrm{F}$, and times extended to almost $10,000 \mathrm{~h}$.

As shown below, two heats (5055 and 5081) have a lower value of Larson-Miller parameter (LMP) $\mathrm{C}$ than that of 5075 , indicating better strength. It was mentioned by Venard that the chemical composition of 5075 was different from that in other two heats, which might be the contribution factor.

The creep ductility increases with the test temperature. The elongation at fracture ranges from 1.5 to $50.3 \%$, and the maximum elongation is larger than that of the five heats mentioned above.

Besides the chemical compositions, the different responses of creep strength and ductility from the previous five heats may be related to the annealing temperature.

The data reported by Venard completed the database for the mill-annealed and laboratory reannealed Hastelloy $\mathrm{N}$ base metal. Other studies that produced creep or stress-rupture data include the MSRE Surveillance activity, reviewed in Chapter 3.1.1 of this report [29-32]. The standard heats in the surveillance activity were 5085,5065 , and 5081 . Those heats were used for making the cylindrical portion, the top and the bottom heads of the MSRE vessel, and the reactor internals, respectively. The modified heats were also tested and evaluated; modifications were 
made to improve irradiation resistance, ability to fabricate, and weldability. Specimens from heats 5911 and 6252 were designed for reactor exposure and had 0.125-in.-diameter gage sections with button head ends that seated into slots machined in the grips [33]. Extension measurements were taken from the movement of the hot grips. Test temperatures were 1202 and $1400^{\circ} \mathrm{F}$ and rupture times were less than $4,000 \mathrm{~h}$.

\subsubsection{Rupture and minimum creep rate}

Rupture data and creep data generated by different heats for similar chemical composition, melting, and heat treatment need to be combined together and transformed into the stress allowable in ASME BPVC tables so that they can be used in design.

Several data analysis methods are available to relate the time and temperature to the stress, including LMP, Orr-Sherby-Dorn parameter, and Manson-Haferd parameter. These models can be used for the lifetime prediction of materials and back analysis of the stress at a specified life, such as $100,000 \mathrm{~h}$. The time-temperature parametric model usually used by the ASME Code analysts is based on the LMP, as defined in Eq. (1):

$$
\mathrm{LMP}=\mathrm{T}(\mathrm{C}+\log \mathrm{tr})
$$

where $T$ is the absolute temperature, $t r$ is the rupture life or the reciprocal of the creep rate, and $C$ is the parametric constant. An increment of 0.1 in the constant $C$ corresponds to a 0.1 decade decrease in the log of rupture life. The LMP is also expressed by a stress function, $f(S)$, that is further written as a polynomial in terms of log stress, $S$,

$$
L M P=f(S)=a 0+a 1 \log S+a 2(\log S)^{2}+a 3(\log S)^{3}+\ldots .
$$

where the coefficients, ai, in $f(S)$ are determined in the analysis along with the parametric constant. Swindeman [11] reviewed and analyzed the data from the three different sources [25, 26, 28]; the results are given in Table 14 for 12 parametric analyses. The analyses include six different groupings of data and two orders for the polynomial—quadratic and cubic -in the log $S$ term. The constant $C$ for rupture data ranged from 12.245 to 13.862, but the standard error of estimate (SEE) was about the same for all the analyses. The constant $C$ for the minimum creep rate (MCR) exhibited a wider range, from 15.892 to 20.562 . Although not shown in the table, the SEE values for the fit to the MCR data were generally lower than those fit to the rupture data. While a higher order of fit does not provide a significant advantage, one can just focus on the lower order. It can be seen that the truncation of data at $90 \mathrm{~h}$ results in a lower constant, as expected. There is insignificant change in $C$ between all data and air data groupings. By focusing on the air data truncated at $90 \mathrm{~h}$, one can see that there is a slightly increase in the constant $C$ in the case of the MSRE, indicating the predominant effect of heat 5075 . It is noted that, although many heats were tested in the past, the number of specimens is quite different between individual heats; therefore, each heat was not equally sampled. In addition, it is interesting to see MSRE data produce the highest stress values, even though the $C$ value is higher than others among the data groupings of $>90 \mathrm{~h}$. The evaluation of the LMP analysis results is needed next in order for the results to be used in the code case development.

The stress values reported in the tables correspond to the average strength $S_{\text {avg }}$ at $100,000 \mathrm{~h}$, the minimum strength $S_{\min }$ at $100,000 \mathrm{~h}$, and stress for MCR $S_{c}$ of $0.01 \% / 1000 \mathrm{~h}$. All values are listed for $1300^{\circ} \mathrm{F}$. The analyses for different groupings of data produced their own stress values. Even so, the $100,000-h$ strengths for the full data grouping and the air data grouping are close. When 
the criteria for Table 1B in Section II-D were applied, it was found that $80 \% S_{\min }$ produced the lowest values for all of the groupings and stress functions.

Table 14 Comparison of the Larson -Miller parametric model for data groupings .

\begin{tabular}{|c|c|c|c|c|c|c|c|}
\hline Group* & $\begin{array}{c}\text { Order of } \\
\text { polynomial }\end{array}$ & Rupture LMP C & $\frac{S E E}{\log h}$ & MCR LMP C & $\begin{array}{c}\text { Savg }_{\text {a }} \\
\text { ksi }\end{array}$ & $\begin{array}{l}S_{\min } \\
k s i\end{array}$ & $\begin{array}{l}S_{c} \\
k s i\end{array}$ \\
\hline \multirow[t]{2}{*}{ All data } & 2 & 13.172 & 0.363 & 15.892 & 6.60 & 4.76 & 5.14 \\
\hline & 3 & 13.354 & 0.354 & 16.696 & 6.15 & 4.67 & 5.14 \\
\hline \multirow[t]{2}{*}{ All >90 h } & 2 & 12.245 & 0.334 & 17.426 & 6.32 & 4.72 & 5.93 \\
\hline & 3 & 12.441 & 0.336 & 17.520 & 5.99 & 4.62 & 5.66 \\
\hline \multirow[t]{2}{*}{ Air } & 2 & 13.460 & 0.367 & 19.840 & 6.51 & 4.56 & 5.49 \\
\hline & 3 & 13.580 & 0.370 & 19.364 & 6.24 & 4.61 & 6.00 \\
\hline \multirow[t]{2}{*}{ Air $>90 \mathrm{~h}$} & 2 & 12.532 & 0.345 & 19.974 & 6.18 & 4.44 & 6.05 \\
\hline & 3 & 12.721 & 0.356 & 18.707 & 6.08 & 4.51 & 5.98 \\
\hline \multirow[t]{2}{*}{ MSRE** } & 2 & 13.862 & 0.362 & 20.562 & 7.46 & 5.29 & 6.18 \\
\hline & 3 & 13.408 & 0.355 & 19.920 & 7.23 & 5.69 & 6.29 \\
\hline \multirow[t]{2}{*}{ MSRE >90 h } & 2 & 13.452 & 0.344 & 20.090 & 7.36 & 5.50 & 6.25 \\
\hline & 3 & 12.770 & 0.341 & 18.801 & 7.04 & 5.50 & 6.04 \\
\hline
\end{tabular}

${ }^{*}$ Based on Swindeman [11]

${ }^{* *}$ Heats 5055, 5075, and 5081.

\subsubsection{Rupture ductility}

The rupture ductility of Hastelloy $\mathrm{N}$ varied from less than $2 \%$ to more than $40 \%$ elongation. Low values were observed at short times for some heats, and often low elongation values were observed at $1100^{\circ} \mathrm{F}$.

There is a trend for the higher values to decrease with increasing rupture life. At $1500^{\circ} \mathrm{F}$ and below, the rupture mode for most conditions was by the linkage of grain-boundary wedge-type cracks. Above $1500^{\circ} \mathrm{F}$, isolated grain-boundary cavities were observed at long times. These linked to form grain-boundary cracks.

\subsubsection{Comparison of rupture data in molten salt with those in air}

Figure 3 provides a comparison of the rupture data in molten salt to the curves produced by the fit of the LMP to the data obtained in air according to Swindeman [11]. There are fewer data points at $1200^{\circ} \mathrm{F}$, all of which fall below the corresponding curve. At other temperatures, the data for molten salts scatter about the curves produced from the analysis of air data. 


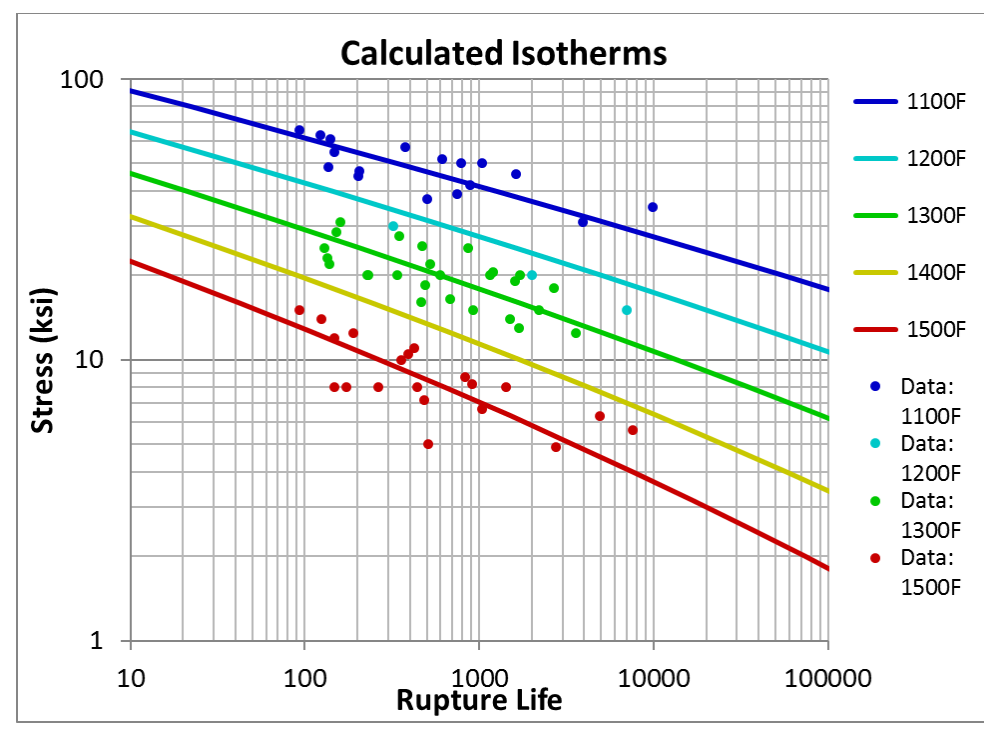

Figure 3 Molten salt data plotted over isothermal curves based on the fit to the air data. Reproduced from Ref. [11].

\subsubsection{Comparison of Hastelloy $\mathrm{N}$ with other candidates}

In Figure 4, creep-rupture data of Hastelloy $\mathrm{N}$ are plotted along with those of Incoloy $800 \mathrm{H}$, SSs 316 , and Haynes 230 at 593, 704, and $816^{\circ} \mathrm{C}\left(1100,1300\right.$, and $\left.1500^{\circ} \mathrm{F}\right)$, respectively. The data are based on the Gen IV Materials Handbook, developed at ORNL [34]. It is obvious that for a given stress level, the creep-rupture life of Hastelloy $N$ is substantially shorter than that of Haynes 230 at all temperatures. Obviously, for operation above $704^{\circ} \mathrm{C}$, a new alloy is desirable that can provide high-temperature strength at least equal to, preferably better than, that of Haynes 230 , while offering environmental resistance the same as or improved over that possessed by Hastelloy N.

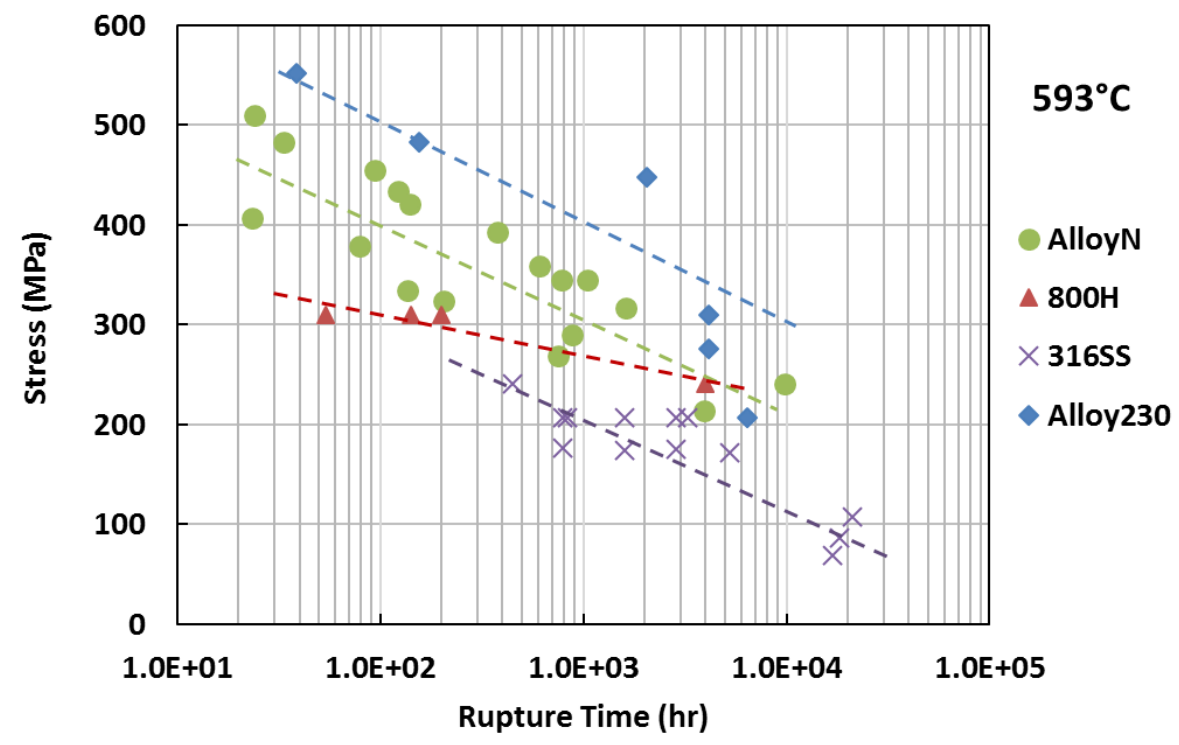

(a) 


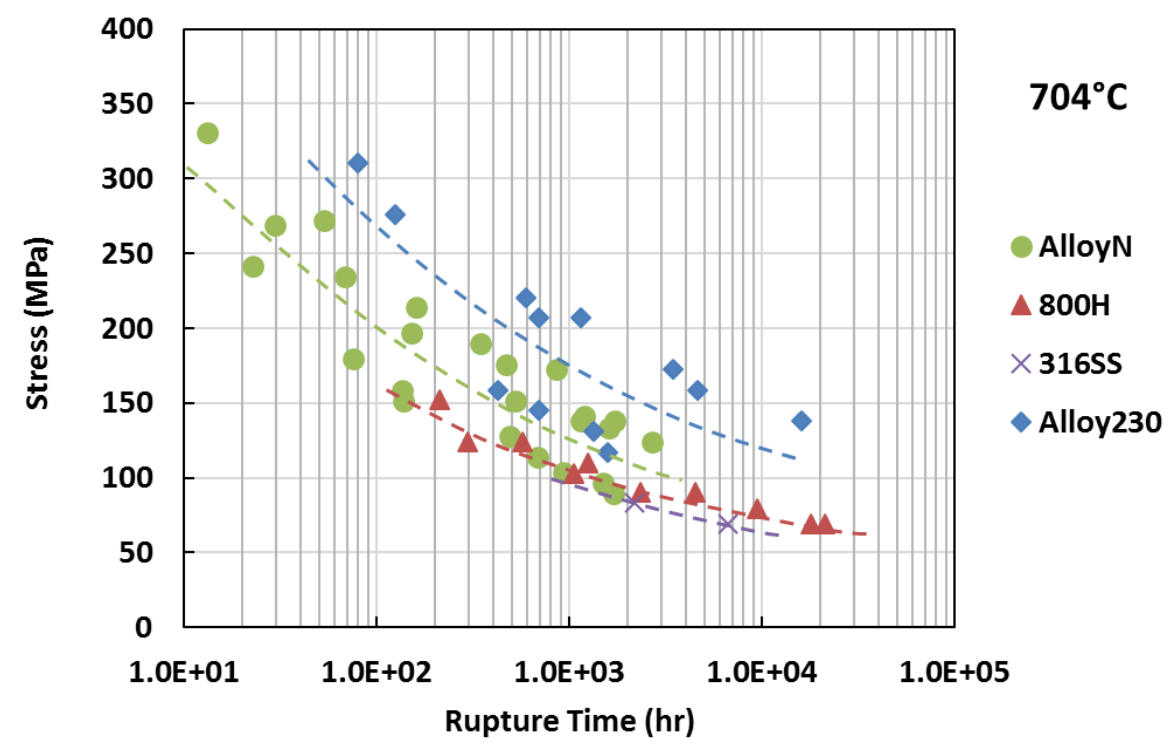

(b)

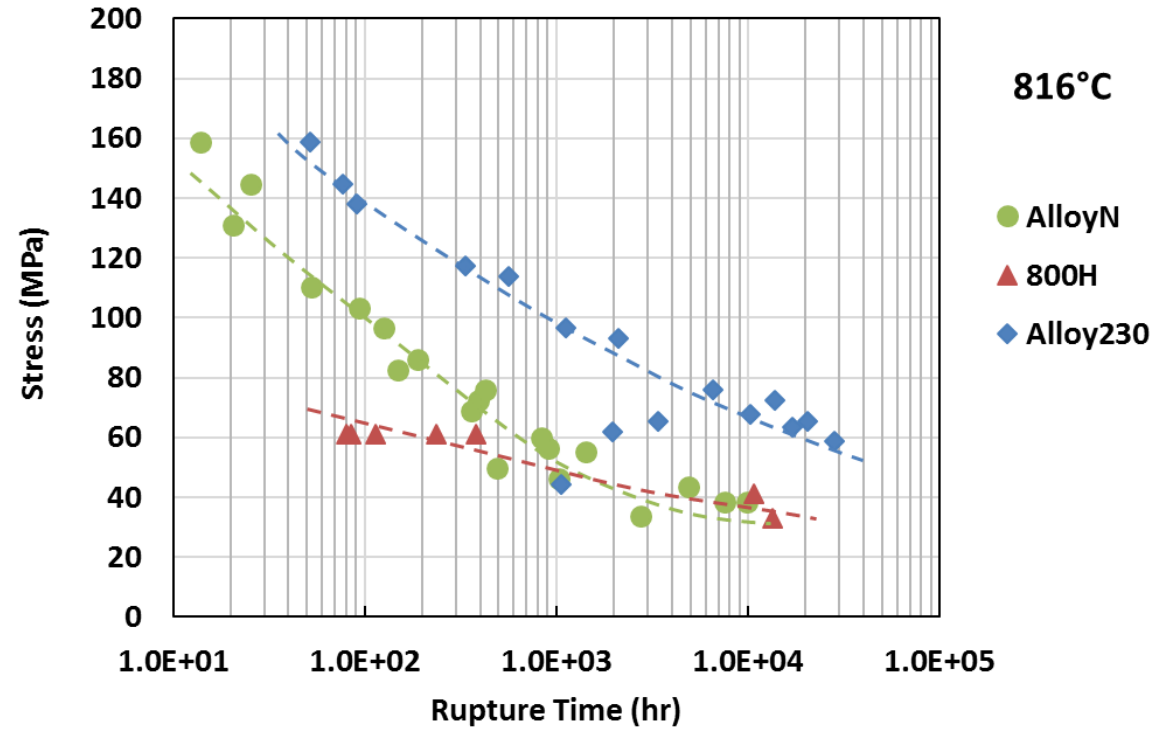

(c)

Figure 4 Creep-rupture stresses of Hastelloy $\mathrm{N}$ at 593, 704, and $816 \mathrm{C}(1100,1300$, and $1500^{\circ} \mathrm{F}$ ) compar ed with those of Incoloy $800 \mathrm{H}$, SS 316, and Hayne s 230. 


\subsection{Time-Independent Properties, Fatigue, and Aging Effects}

\subsubsection{Tensile strength}

Some of the heats of Hastelloy $\mathrm{N}$ listed in Table 12 were also investigated in tensile tests at the same time as rupture tests. Two of the heats were above the carbon specification, namely 8M1 and 1327 , while several heats were slightly above the maximum for silicon content.

The first known reporting of tensile properties was by Schultz [25]. The material was a 0.063 -in. sheet of heat 8284 . The sheet was mill-annealed for 8 minutes at $2150^{\circ} \mathrm{F}$ and rapidly air-cooled. The results of the average of four duplicate tests at temperatures from RT to $1700^{\circ} \mathrm{F}$ are provided in the referenced report.

The second source of tensile data is the report by Swindeman in 1961 [26], including four heats (SP-16, SP-19, 8M-1, and M1566). Both 0.063-in.-thick sheet and 0.505-in. rod specimens were tested. Testing was performed in a 12,000-lb-capacity or 120,000-lb.-capacity Baldwin hydraulic testing machine equipped with a strain pacer to maintain a testing rate of $0.05 / \mathrm{min}$ to beyond the yield strength. The yield curves needed for buckling charts were performed on 0.505-in.-diam. rod specimens of heat SP-16 at this time. The results of the yield and ultimate strengths for three of the heats are given in Figure 5 and Figure 6 , along with those of other heats. There were variations from heat to heat, but they were reflected only in the yield strength and elongation. Heat 8M-1, high in carbon with a fine grain size (ASTM No. 5-7), exhibits the highest yield strength (not shown); while SP 16, low in carbon and coarse-grained (ASTM No. 2-4), is the weakest. The elongation is generally constant up to $1000^{\circ} \mathrm{F}$ but rapidly drops to a minimum value near $1500^{\circ} \mathrm{F}$. The elongation decreases with increasing carbon content and/or decreasing grain size, except for $\mathrm{M}-1566$, which is the least ductile above $1000^{\circ} \mathrm{F}$.

Effect of notches: Tests were performed on notched-rod specimens of SP 19-3 at several temperatures. These specimens had a gage diameter of $0.357 \mathrm{in}$. and a notch radius of $0.005 \mathrm{in}$. As in the case of most metals, the effect of the notches was to increase the ultimate tensile strength (UTS); but at the lower temperatures, the increase for Hastelloy $\mathrm{N}$ was only slight. The notched to unnotched strength ratios at $\mathrm{RT}, 1000,1200$, and $1500^{\circ} \mathrm{F}$ were $1.08,1.07,1.13$, and I.38, respectively.

Fracture characteristics and microstructure: The temperature at which the ductility began to drop corresponds to the temperature at which grain-boundary fracture began to occur. Below $1000^{\circ} \mathrm{F}$, the fracture was predominately transgranular, whereas above this temperature, the fracture became intergranular.

Some tensile testing was reported by Carden in 1965 [35]. The tests were on heat 5050 after annealing at $2300^{\circ} \mathrm{F}$. Tests were performed in a 10,000 -lb-capacity Instron machine at a crosshead rate of $0.01 /$ minute. The yield strength produced for this heat was relatively high at temperatures from 400 to $1200^{\circ} \mathrm{F}$.

Three heats of commercial plate products were evaluated by Venard and the results were reported in 1965 [28]. Tensile data were produced from tests of 0.276-in.-diam. rod specimens of two heats, 5075 and 5081, using a 12,000-lb-capacity Baldwin Hydraulic machine at a crosshead speed of $0.05 /$ minute.

A number of other studies that produced tensile data included the MSRE surveillance activity [2932], independent irradiation tests [33], and aging studies associated with other applications for 
Hastelloy $\mathrm{N}$ [36]. Some tube-burst tests were performed on thin-wall tubing as control data in a study of irradiation effects [37]. These very fine-grained tubes were not representative of the coarser-grained bar and plate products. None of these studies produced test data that could be used to supplement the database assembled.

Figure 5 and Figure 6 also show the results of the re-analysis of the tensile yield and ultimate strength data for Hastelloy $N$ according to Swindeman [11]. Because the procedure outlined in Appendix 1 of ASME BPVC Section II, Part D, requires the establishment of a trend curve based on the ratio of the elevated temperature strength to the RT strength, heats that lacked RT strengths were not included in the analysis. Included is the trend line $\left(R_{y}\right)$ based on a "best fit" polynomial through the ratio data and anchored to the specified minimum yield strength $\left(S_{y}\right)$, which produces the $\mathrm{Y}-1$ curve $\left(S_{y} R_{y}\right)$ to $1000^{\circ} \mathrm{F}$. Extending the curve above $1000^{\circ} \mathrm{F}$ produces $S_{y}$ values for Section III.

The ratio of the elevated-temperature ultimate strengths to the RT strengths for eight heats is plotted against temperature in Figure 6. The trend line $\left(R_{T}\right)$ is included and is based on a "best fit" polynomial through the ratio data. Following the procedure in ASME BPVC Section II-D Appendix 1 , the $\mathrm{R}_{\mathrm{T}}$ trend line has been anchored on the specified minimum ultimate strength, $\mathrm{S}_{\mathrm{T}}$. In Figure 6 , this trend is compared with the data for the eight heats. The resulting $S_{T} R_{T}$ curve, when multiplied by a factor of 1.1 for temperatures above $100^{\circ} \mathrm{F}$, forms the basis for the $U$ values in ASME BPVC Section II, Part D. Extending the curve to temperatures above $1000^{\circ} \mathrm{F}$ produces $\mathrm{S}_{U}$ values for ASME BPVC Section III.

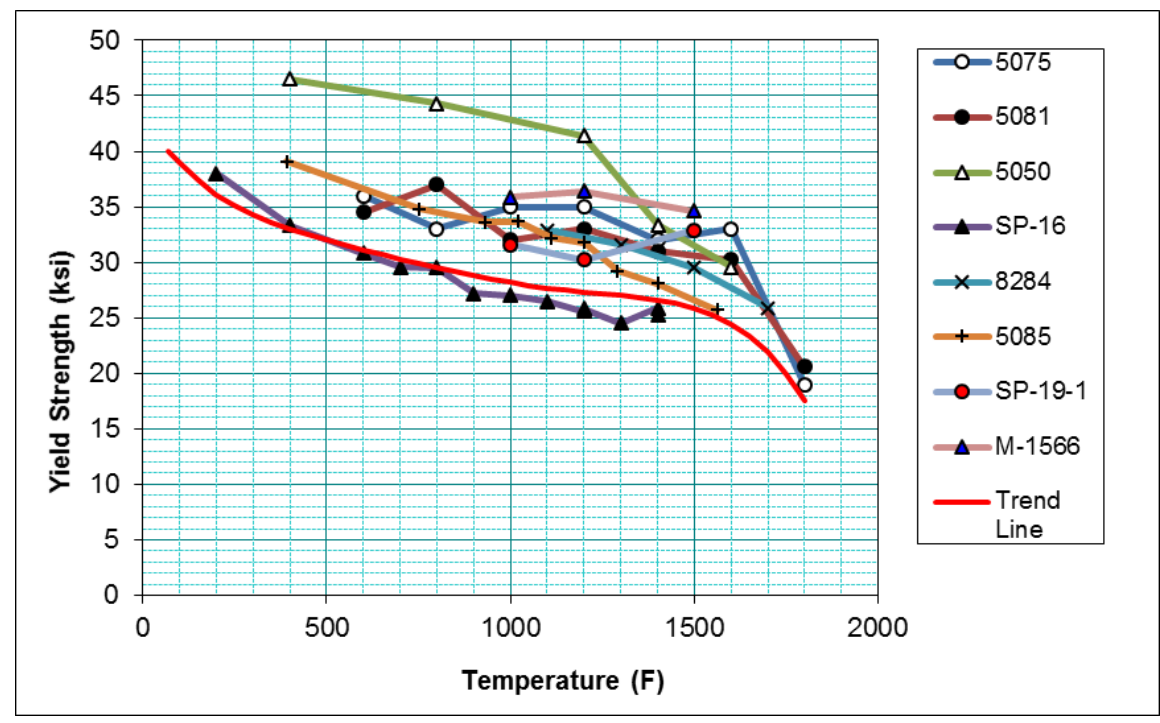

Figure 5 Comparison of yield strength data with the $S{ }_{y} R_{y}$ curve for Hastelloy $N$. Reproduced from Ref. [11]. 


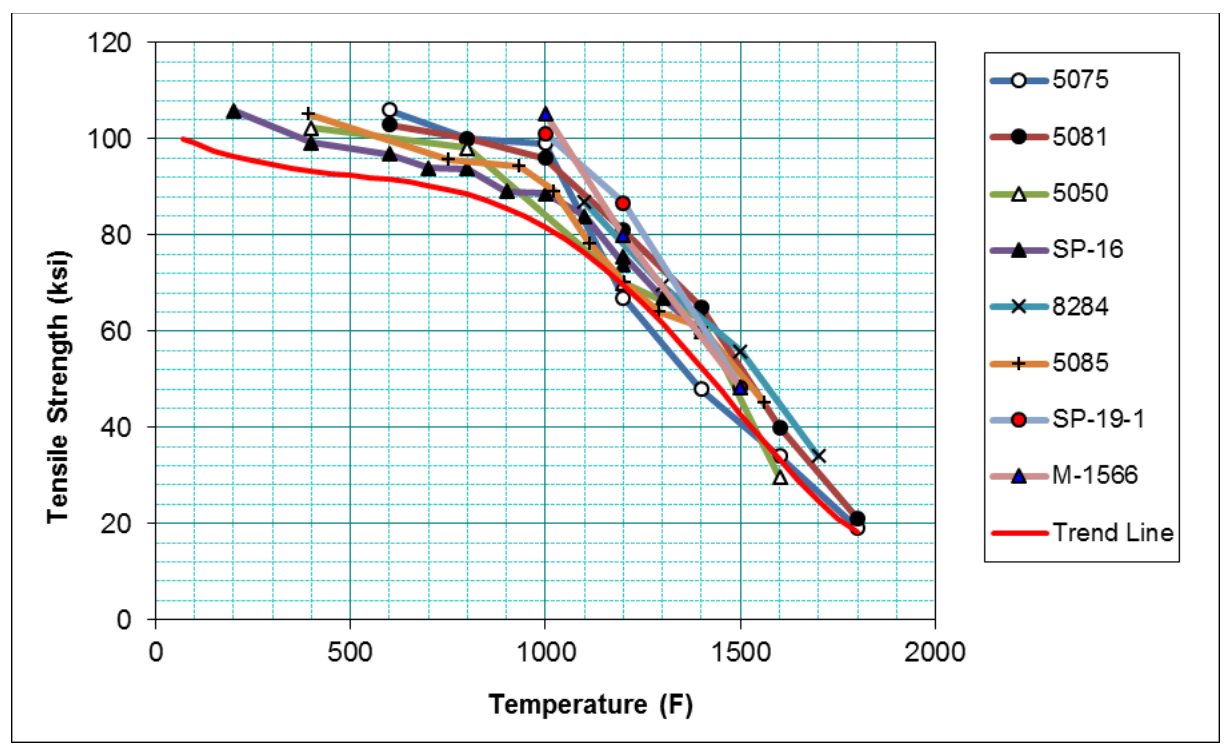

Figure 6 Comparison of ultimate tensile strength data with the $S T_{T} R_{T}$ curve for Hastelloy $N$. Reproduced from Ref. [11].

\subsubsection{Stress - and strai n-controlled fatigue}

Stress-controlled fatigue data were produced by Battelle Columbus Laboratories on a bar product of heat SP-19 [38]. Two grain sizes were studied, ASTM number 2 for Group 1 and number 5 for Group 3. Rotating-beam tests were performed at 1100,1300 , and $1500^{\circ} \mathrm{F}$ at frequencies of 100 , 600 , and 3000 cycles per minute (cpm). The reported stresses (amplitudes) exceeded the yield strengths at the testing temperatures; hence, stress redistribution and significant work hardening were present in the specimens. The coverage was in the intermediate cycle range from $10^{4}$ to beyond $10^{7}$. Fatigue curves extracted from the reports are provided in Figure 7 through Figure 9 for 1100,1300 , and $1500^{\circ} \mathrm{F}$, respectively.

Of the two grain sizes studied, the finer-grained material has greater fatigue strength. For a specified grain structure, the fatigue strength deceases with the temperature as expected. There is a critical frequency associated with each temperature, above which frequency has no effect on strength, but below which fatigue strength decreases with decreasing frequency. 


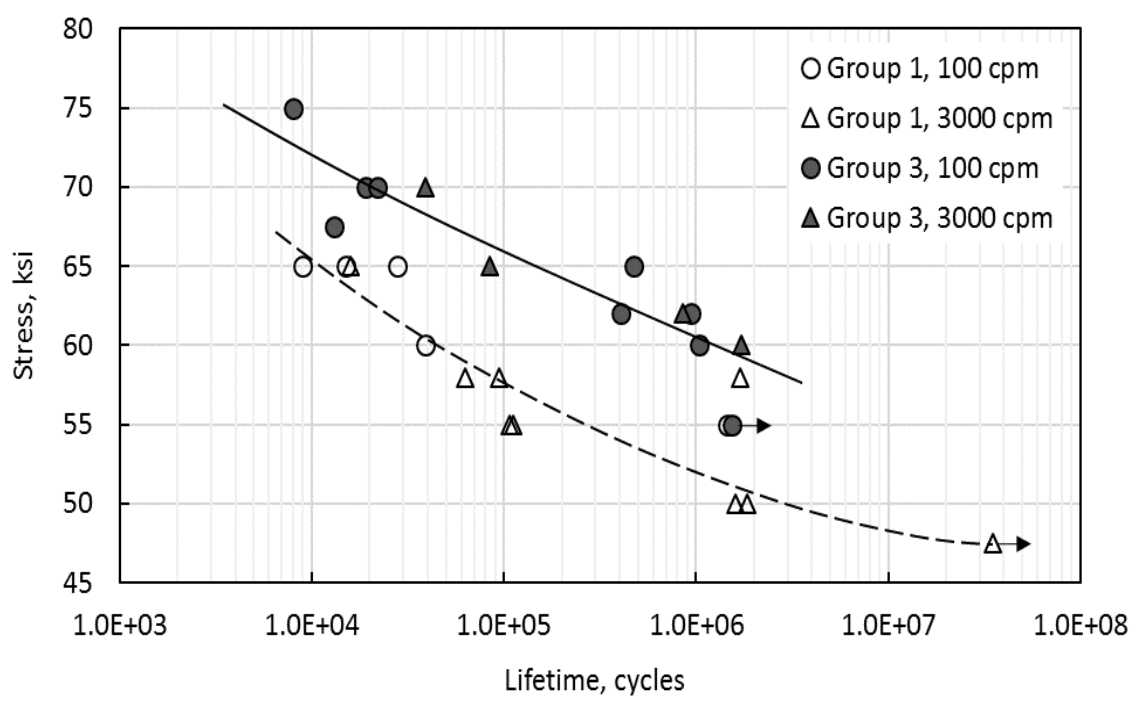

Figure 7 Rotating beam fatigue for Hastelloy N (SP -19) at $1100^{\circ}$ F. Replotted from Ref. [38].

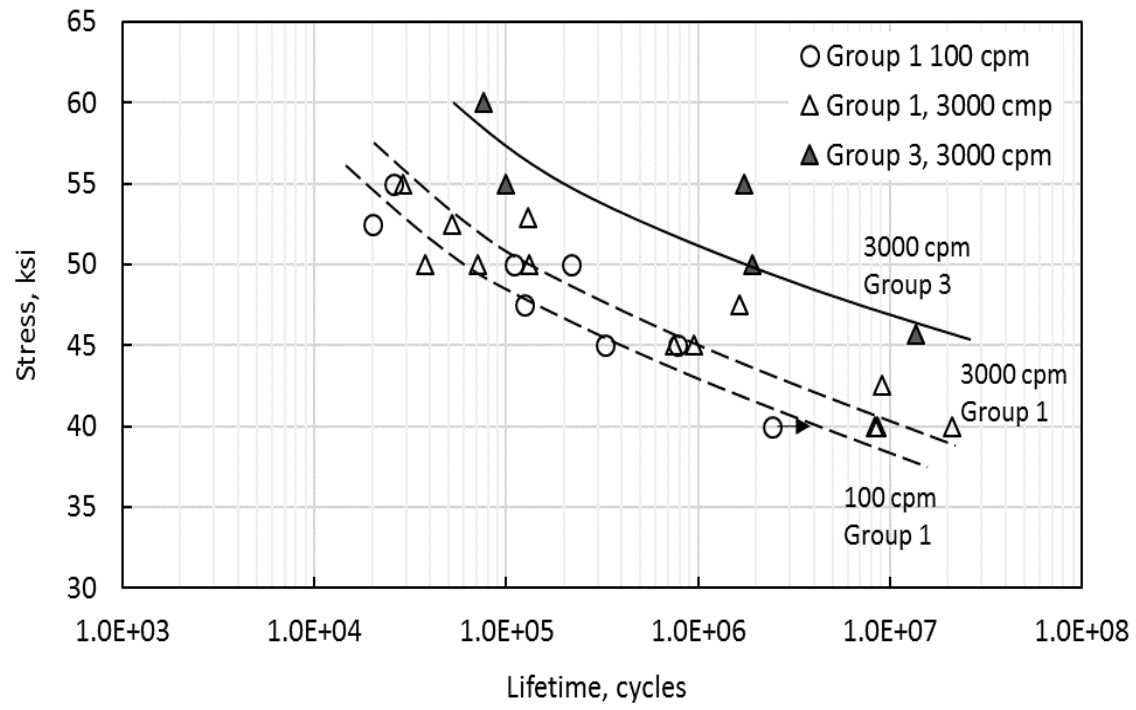

Figure 8 Rotating beam fatigue for Hastelloy N (SP -19) at 1300 F. Replotted from Ref. [38]. 


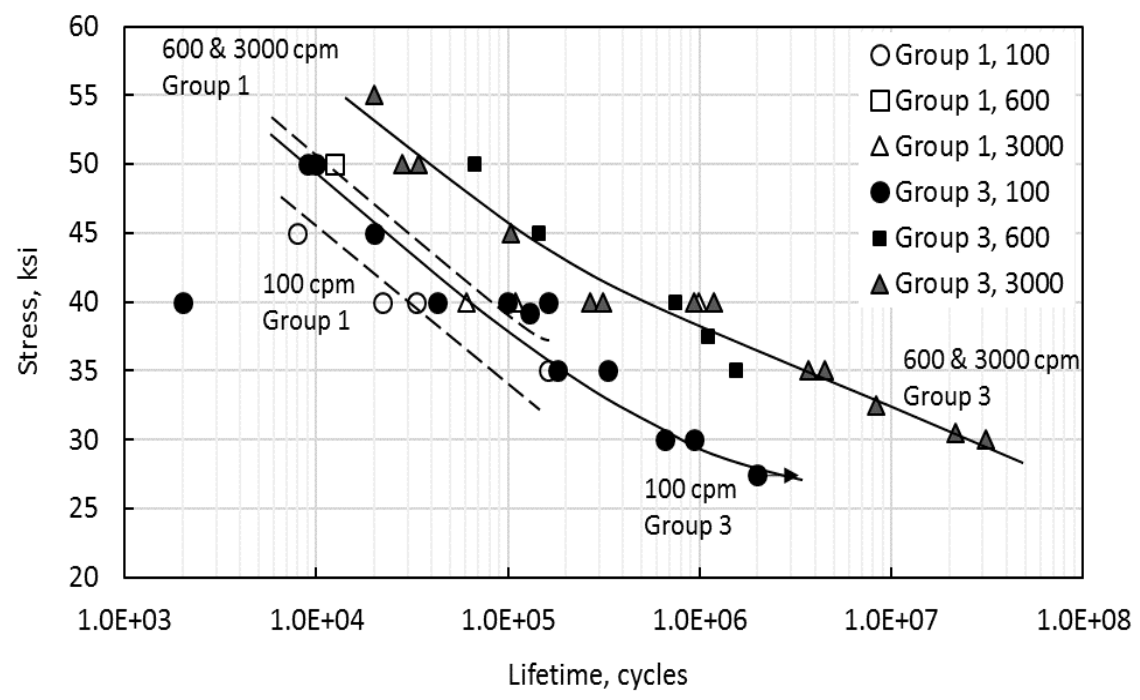

Figure 9 Rotating beam fatigue for Hastelloy N (SP -19) at $1500^{\circ}$ F. Replotted from Ref. [38].

McCoy and Weir published strain-fatigue data for Hastelloy $\mathrm{N}$ but did not provide the source of the data [39]. The plastic-strain versus cycle fatigue curve is shown in Figure 10, which covers temperatures from 1300 to $1600^{\circ} \mathrm{F}$ and the life range from 10 to $10^{4}$ cycles. No temperature dependence appears in the trend of the data.

Thermal fatigue data were also produced by Carden and co-workers [40, 41] in the same temperature range. These tests were performed on specimens of tubular and bar geometries obtained from a production heat of Hastelloy N (heat 5050).

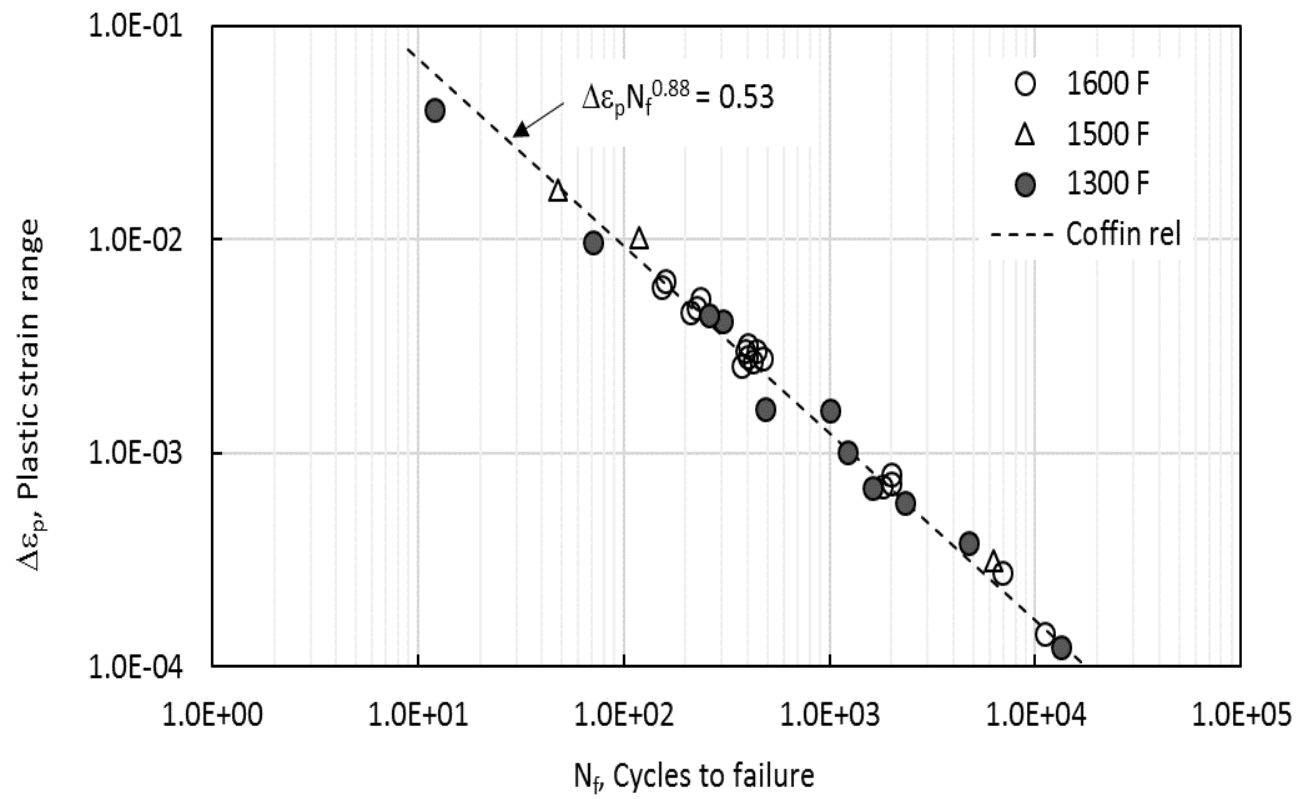

Figure 10 Plastic strain range versus cyclic life for Hastelloy N. Replotted from Ref. [39]. 
One set of curves serving as a basis of the fatigue analyses of the MSRE components was developed by Briggs [42] , as shown in Figure 11. The curves were derived from the data produced by Carlson and Carden et al. referred to above [38, 40, 41]. The curves represent temperatures of 1100,1300 , and $1500^{\circ} \mathrm{F}$ for the coarse-grained material at the cyclic frequency of $100 \mathrm{cpm}$ and are based on a reduction factor of 2 on stress amplitude and 20 on cycles.

Corum's curves [43] differed significantly from those produced by Briggs. He constructed curves for 1200 and $1300^{\circ} \mathrm{F}$ for conditions of complete stress relaxation and for no stress relaxation in the cycle. He used a factor of 1.5 to reduce the plastic strain amplitude and a factor of 10 to reduce cycles, as shown in Figure 12 and Figure 13, for the complete stress relaxation condition; "DeP" stands for plastic strain range in the figures. Again, he used a factor of 1.5 to reduce the total strain amplitude and a factor of 10 to reduce cycles, as shown in Figure 14 and Figure 15, for the no stress relaxation condition; "DeT" stands for total strain range in those figures.

The fatigue curves of Briggs and Corum could be converted to strain range versus cycles similar to the curves in ASME BPVC Section III-5 Figure HBB-T-1420-1x. When compared with the curves for $304 \mathrm{H}$ and $316 \mathrm{H}$ on this basis, the curves produced by the Briggs model tend to show lower strain tolerance at low cycles and about twice the tolerance at high cycles. The curves for the Corum model more closely match the curves for the stainless steels and Incoloy $800 \mathrm{H}$.

The concept of creep-fatigue damage was under development at the time the fatigue curves for Hastelloy $\mathrm{N}$ were being constructed for use with Code Case 1331-3 [44]. Currently, no creepfatigue data are available for Hastelloy $\mathrm{N}$.

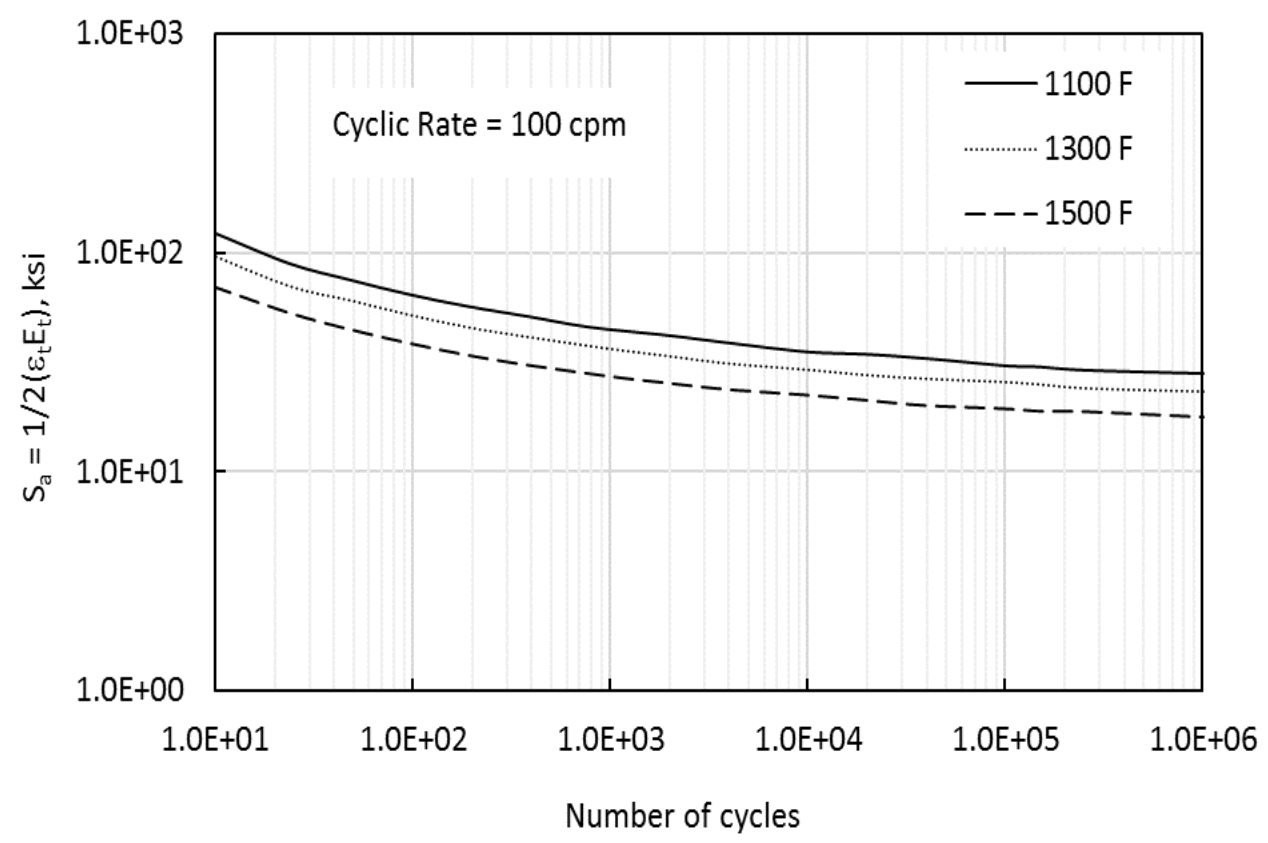

Figure 11 Design fatigue curves, $S_{a}$, for Hastelloy N produced by Briggs in 1969. Replotted from Ref. [42]. 


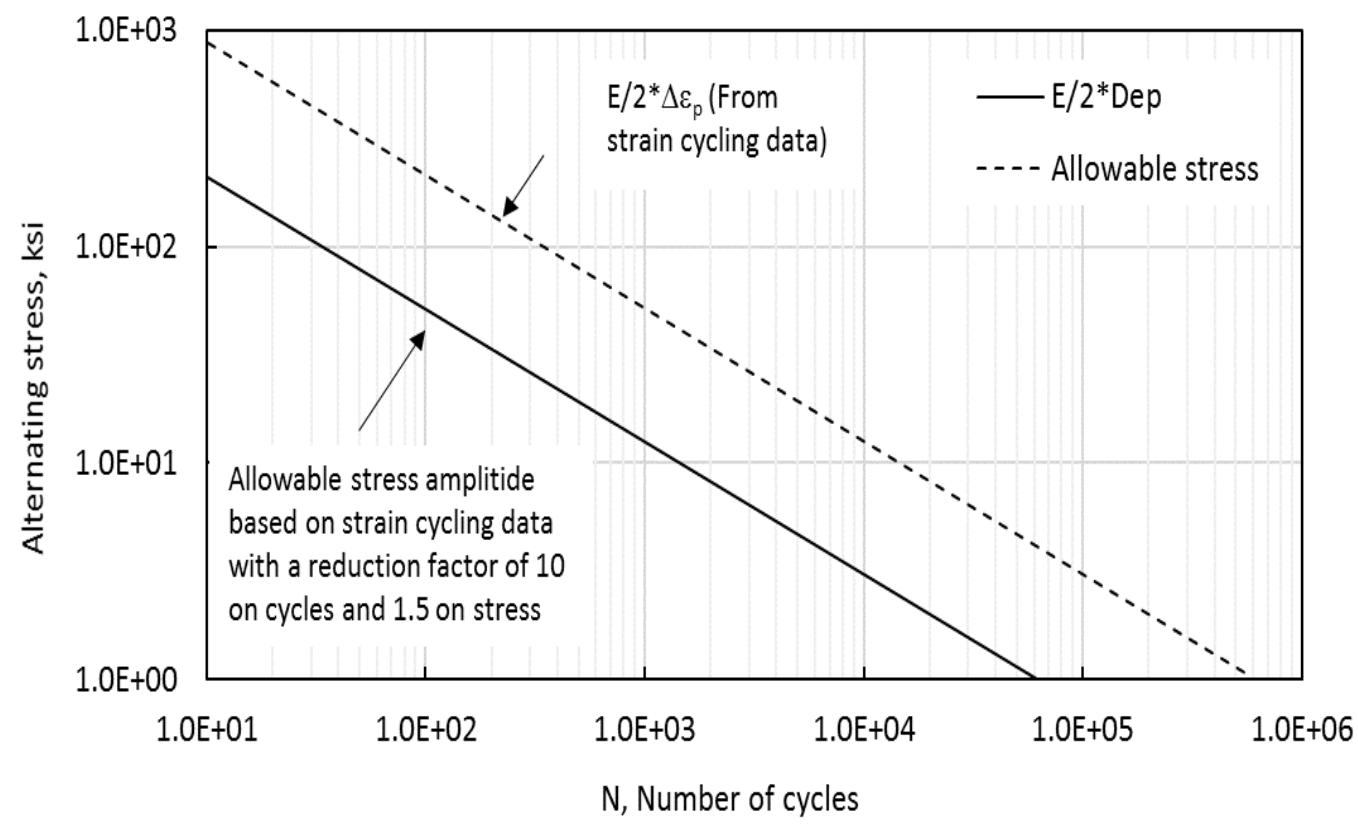

Figure $12 S_{a}$ vs $\mathrm{N}$ for complete relaxation at $1200^{\circ} \mathrm{F}$. Dep = plastic strain range. Replotted from Ref. [43].

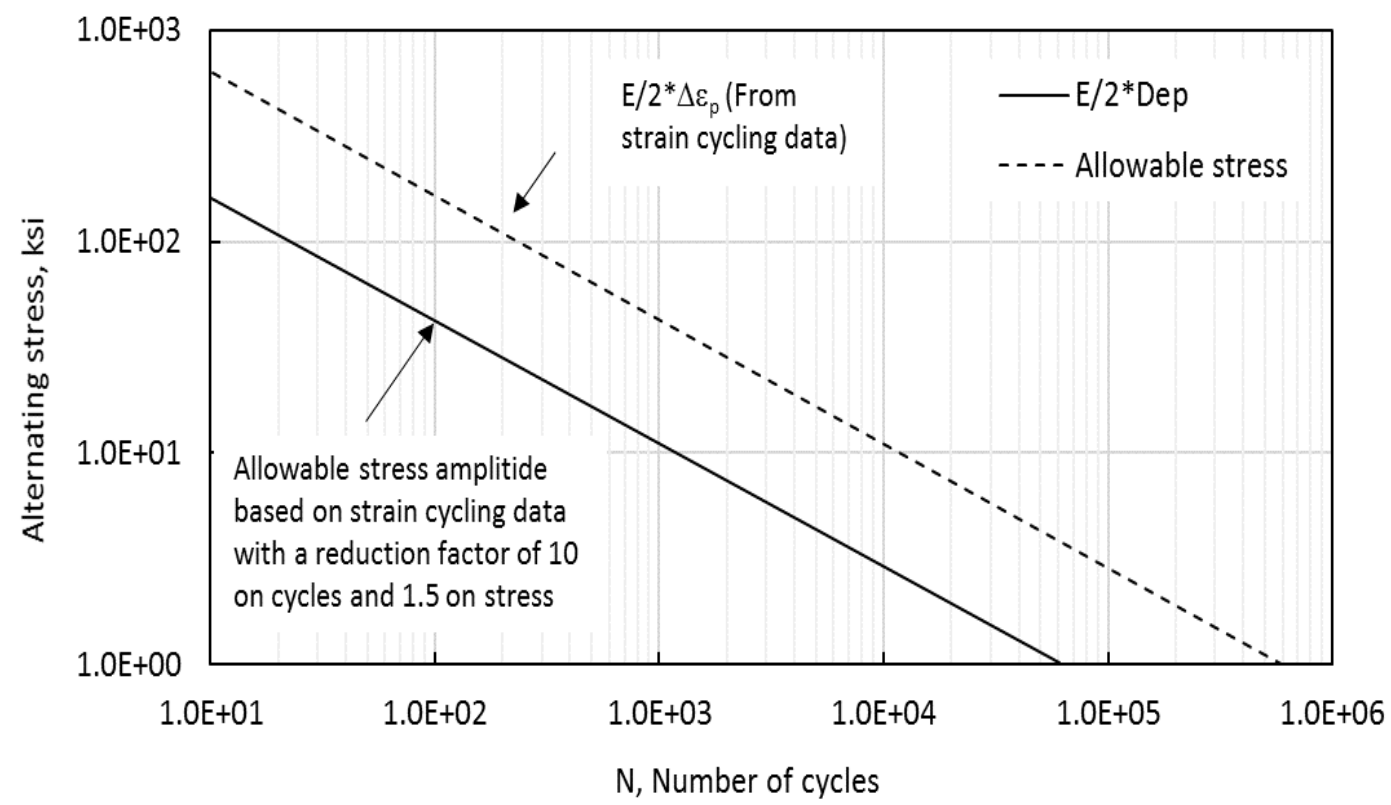

Figure $13 S_{a}$ vs $\mathbf{N}$ for complete relaxation at $1300^{\circ} \mathrm{F}$. Dep = plastic strain range. Replotted from Ref. [43]. 


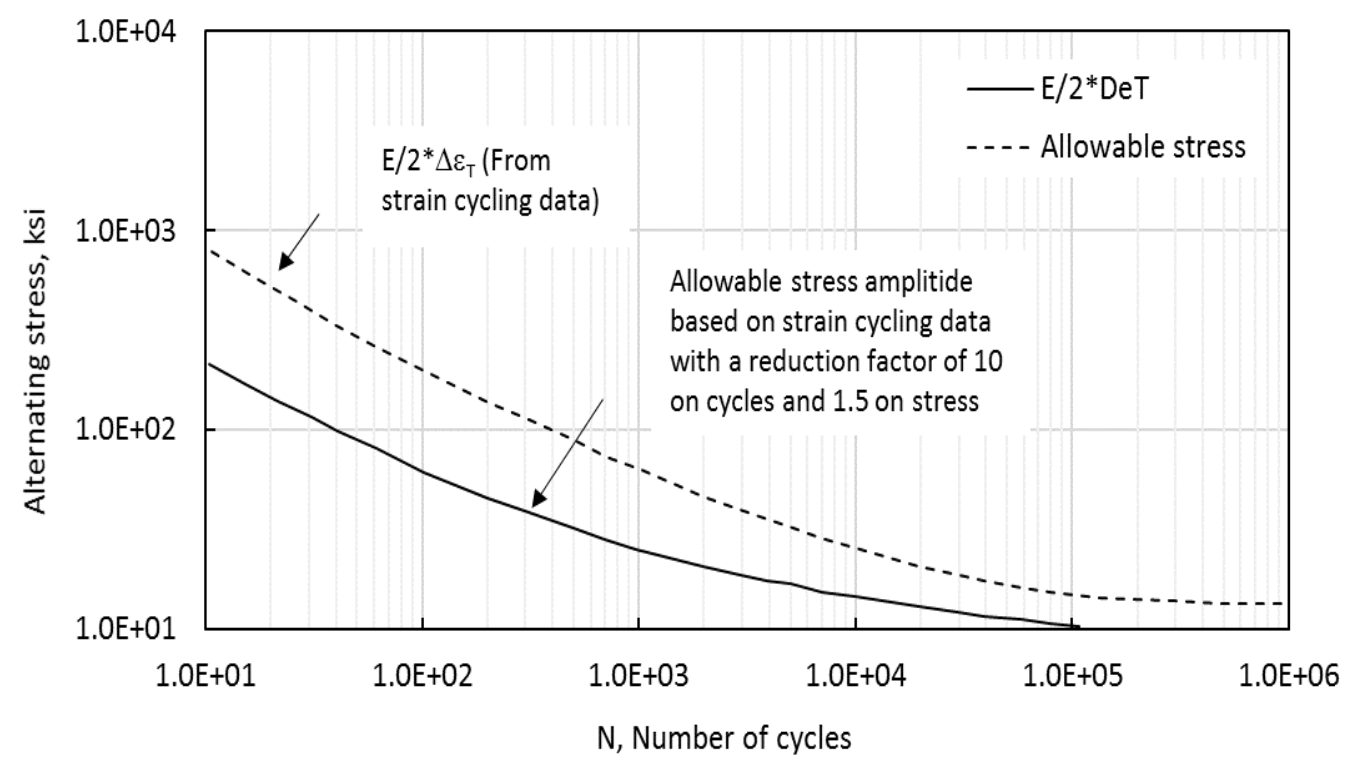

Figure $14 S_{a}$ vs $\mathrm{N}$ for no relaxation at $1200^{\circ} \mathrm{F}$. DeT = total strain range. Replotted from Ref. [43].

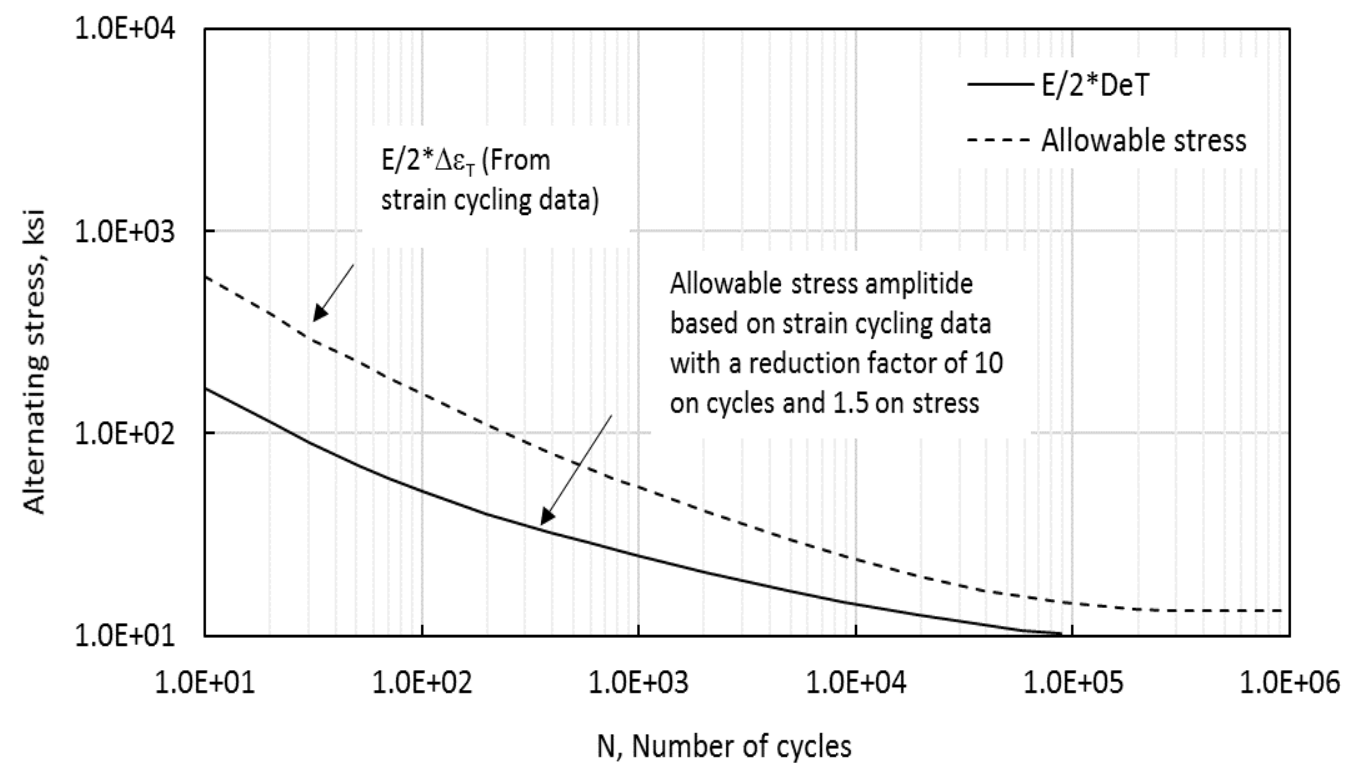

Figure $15 S_{a}$ vs $\mathbf{N}$ for no relaxation at $1300^{\circ} \mathrm{F}$. DeT = total strain range. Replotted from Ref. [43].

\subsubsection{Relaxation behavior}

An understanding of the relaxation behavior is important in establishing rules for creep-fatigue evaluation. Some guidelines are provided in ASME BPVC Section III-5. One approach requires the use of isochronous stress-strain diagrams (HBB-T-1433). These diagrams have not been established for Hastelloy N; however, relaxation data have been reported [26, 45]. The relaxation curves in Figure 16 cover temperatures from 1200 to $1600^{\circ} \mathrm{F}$, with most curves going to at least $100 \mathrm{~h}$. These tests were performed at ORNL on heat SP-16 bar specimens and the holding strain was $0.1 \%$. Duplicate tests were performed at some temperatures. Figure 17 shows the results of testing at the University of Alabama on a plate product of heat 5050 where "eT" stands for the 
constant strain. Tests were at $1300^{\circ} \mathrm{F}$ at two strain levels $(0.378 \%$ and $0.215 \%)$. These test data are compared with a test at ORNL on heat SP-16 at a strain level of $0.2 \%$.

Often, the creep curves for Hastelloy $\mathrm{N}$ exhibit very little primary creep; and at low strains, one might expect a minimum of strain hardening. For this condition, it should be reasonable to expect that the relaxation behavior could be calculated from the minimum creep rate or the rate based on the time to $1 \%$ creep using a simple time-hardening model, as discussed by Roberts [46]. The analysis showed the calculated relaxation curve seemingly fits well to the observed curves for tests at $1400^{\circ} \mathrm{F}$ on heat SP-16 [11].

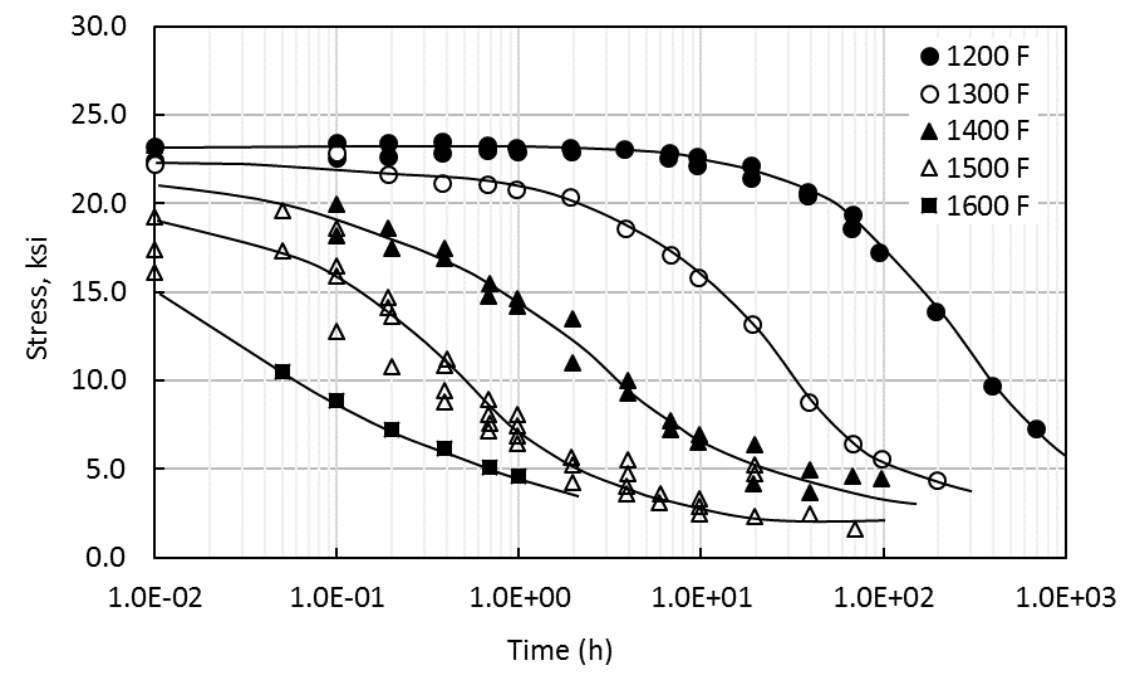

Figure 16 Relaxation data for heat SP -16 for $0.1 \%$ strain. Replotted from Ref. [26].

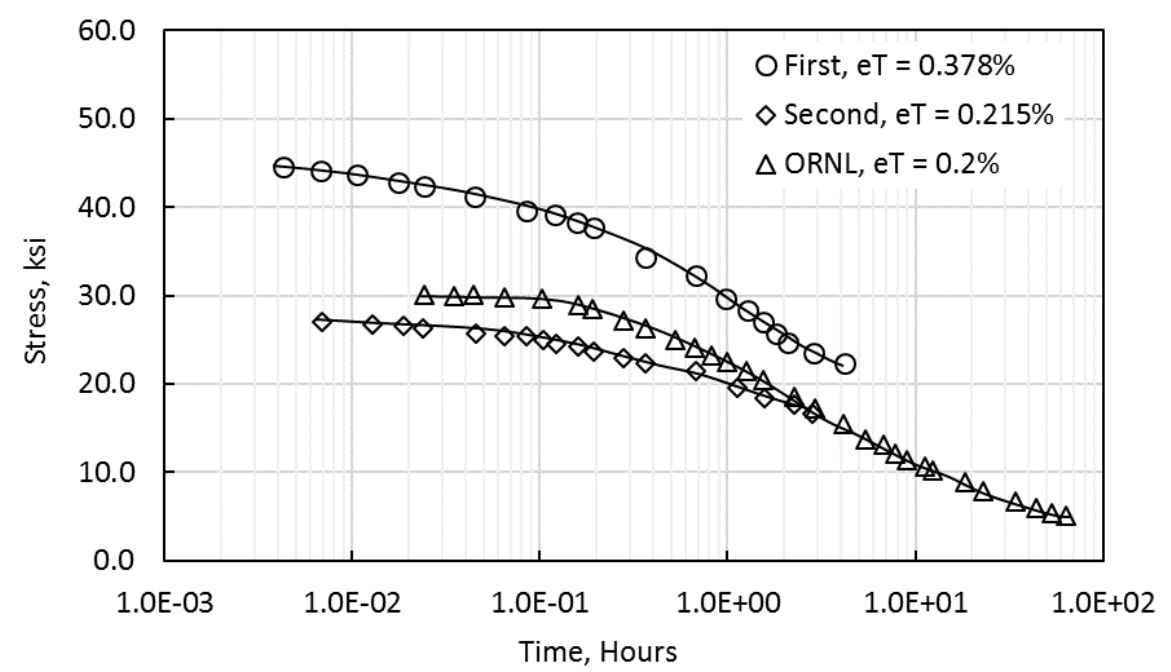

Figure 17 Relaxation data for heat 5050 for two strains at $1300{ }^{\circ} \mathrm{F}$. eT = constant strain. Replotted from Ref. [45]. 


\subsubsection{Effect of service life on short -time properties}

Hastelloy $\mathrm{N}$ undergoes aging and its short-time tensile properties are expected to change during service exposure, although it is considered a solid solution-strengthened alloy. Consideration of aging effects may be addressed with respect to Table HCB-II-2000-5 of ASME BPVC Section III5 . Early work on short-time aging effects- $128 \mathrm{~h}$ at $1500^{\circ} \mathrm{F}$-was undertaken by Haynes [25]. Haynes found very little change in RT strength and ductility. Some tensile testing by ORNL after creep exposure to around 10,000 h was conducted in the early 1960s [47]. The tests showed mixed results with respect to changes in strength and ductility, but the ductility at high temperature was generally acceptable. Hammond examined the aging response at $1500^{\circ} \mathrm{F}$ on sheet specimens of heat 5108 [36]. He found a small increase in the yield strength up to $1400^{\circ} \mathrm{F}$, whereas the tensile strength and ductility decreased in most of the same temperature range. The trends are shown in Figure 18.

Extensive studies of aging effects were undertaken by McCoy as part of the MSRE Surveillance work [29-32]. He included three heats of commercial materials (heats 5085, 5081, and 5065) in a surveillance program to examine the influence of irradiation on the strength and ductility. The control samples were from annealed material but were stress relieved for $2 \mathrm{~h}$ at $1650^{\circ} \mathrm{F}$ after machining. Aging for heat 5085 was performed at $1202^{\circ} \mathrm{F}\left(650^{\circ} \mathrm{C}\right)$ for about $4,800 \mathrm{~h}$ (first group), $15,289 \mathrm{~h}$ (third group), and 22,533 $\mathrm{h}$ (fourth group). The results for heat 5085 after 22,533 $\mathrm{h}$ are plotted in Figure 19, where they are compared to the data obtained by Venard on mill-annealed material. Very little change in strength and ductility is apparent. Similar data were provided for the other two heats.

These data are available for an assessment of the factors to apply to service-exposure in ASME BPVC Section III Division 5. It does not appear that an aging factor needs to be applied for the loss of yield or tensile strength at temperatures above $800^{\circ} \mathrm{F}$. 


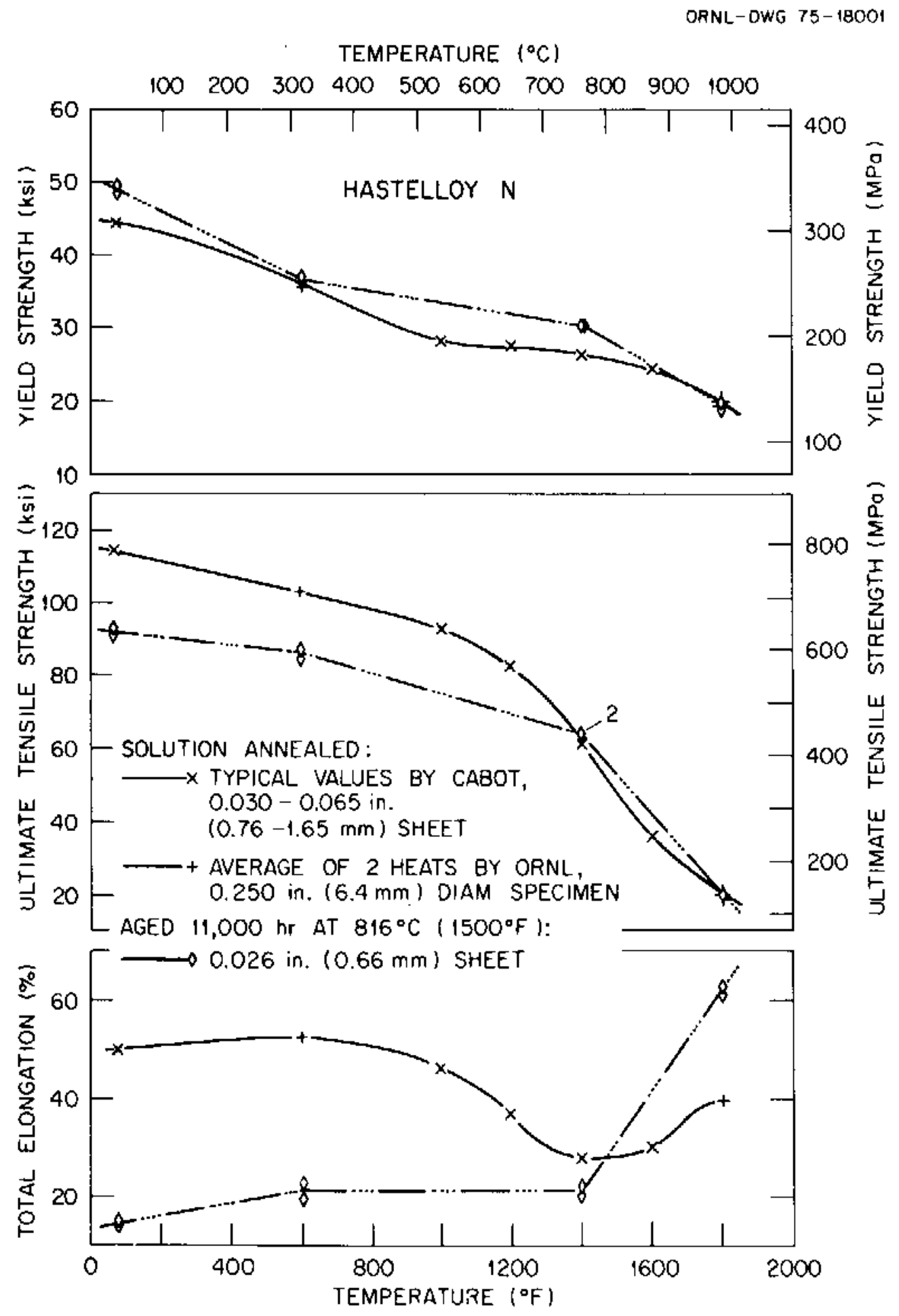

Figure 18 Effect of aging at $816^{\circ} \mathrm{C}\left(1500^{\circ} \mathrm{F}\right)$ on tensile properties of Hastelloy $\mathrm{N}$ (heat 5108$)$ sheet samples. Reproduced from Ref. [36]. 


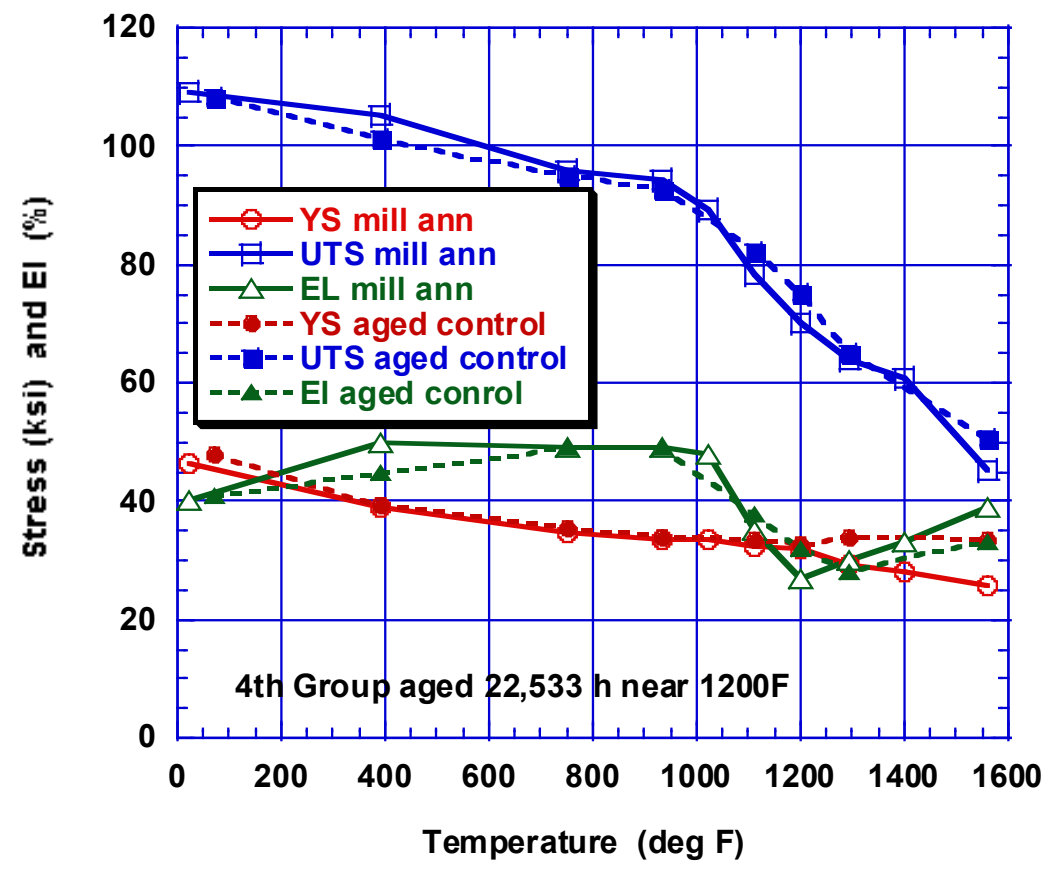

Figure 19 Effect of aging for 22,533 hours at $650^{\circ} \mathrm{C}\left(1202^{\circ} \mathrm{F}\right)$ on the tensile properties of Hastelloy $\mathbf{N}$ (heat 5085). Control specimens were in the mill-annealed condition. Samples were treated for $2 \mathrm{~h}$ at $900^{\circ} \mathrm{C}\left(1650^{\circ} \mathrm{F}\right)$ before aging. The strain rate was $0.05 / \mathrm{min}$ for the aged material. Reproduced from Ref. [11].

\subsection{Joints, Weldments, and Fabrication -Related Material Issues}

\subsubsection{Material fabrication}

Hastelloy $\mathrm{N}$ has proved to be readily fabricable into many basic material forms (pipe, tube, plate, bar, casting) required in the fabrication of a complex engineering system such as a nuclear reactor [39].

Melting and casting is carried out by using conventional practices for $\mathrm{Ni}$ and its alloys. Ingots for the MSRE were prepared by both air and vacuum induction or consumable arc melting. Individual melts of up to $10,000 \mathrm{lb}$ and a total quantity of almost $200,000 \mathrm{lb}$ were produced. Castings have been made in molds of water-cooled copper, graphite, rammed magnesia, cast iron, and sand. It is easier to control the chemical analysis by vacuum melting, and the metal produced has better mechanical properties and fabricability [39].

In making the many different forms and sizes of material during the development and construction of the MSRE, Hastelloy $\mathrm{N}$ was fabricated using the normal techniques for Ni-based alloys. The initial fabrication or breaking down of the ingots was accomplished by forging or extrusion. Temperatures varied from 1825 to $2250^{\circ} \mathrm{F}$. Secondary fabrication was accomplished using both hot and cold methods. Acceptable techniques included rolling, swaging, tube reducing, and drawing. The alloy work hardened when fabricated cold, but reductions in area of up to $50 \%$ were possible between anneals. Temperatures of 2100 to $2200^{\circ} \mathrm{F}$ were used for hot rolling, with reductions of about $10 \%$ per pass. The standard finished annealing temperature for this alloy is $2150^{\circ} \mathrm{F}$. All material for the MSRE was annealed after forming or working. After final fabrication, all material was stress-relieved at $1600^{\circ} \mathrm{F}$. For any heat treatment, the cooling rate to $600^{\circ} \mathrm{F}$ was 
limited to $400^{\circ} \mathrm{F}$ per hour per inch of thickness. The slow cooling helped to impart dimensional stability and improved the ductility in the 1400 to $1800^{\circ} \mathrm{F}$ range.

\subsubsection{Review of welding}

Extensive experience with Hastelloy $\mathrm{N}$ has shown that it exhibits relatively good weldability. The MSRE contained hundreds of satisfactory tungsten-arc welds in varied section sizes. The welds were made using procedures developed at ORNL for nuclear-quality applications.

During the investigation of the weldability of Hastelloy $\mathrm{N}$, welding problems were encountered. Hot cracking of the type encountered in welding high-Ni alloys was observed in heavily restrained joints both in experimental heats and in later commercial heats.

1. A series of studies indicated that cracking was associated with the segregation of alloying elements in the heat-affected zones (HAZs) of Hastelloy $N$ weldments [48].

2. Microstructural changes because of welding were studied; microprobe analyses of the samples showed that the brittle eutectic-type structure had a markedly different composition from that of the matrix.

In the MSRE era, the GTAW process was the only technique used for the construction of reactors using Hastelloy $\mathrm{N}$. The filler metal was of the same basic composition as the wrought product. The RT mechanical properties of Hastelloy $\mathrm{N}$ weldments have been extensively investigated [39]. During the qualification of welding procedures for this alloy in accordance with the ASME BPVC, numerous bend and tensile tests were conducted. The results readily satisfied the ASME requirements. However, as was expected, the ductility of the welds was not as good as those obtained for the base metal. Elevated-temperature studies of the weld showed that they had lower ductility and creep-rupture strength than the base metal, as is discussed in the following section. However, stress relief at $1600^{\circ} \mathrm{F}$ improved the properties sufficiently that they were comparable with those of the base metal.

\subsubsection{Time-independent properties of welds}

Data for weld metal and weldments were reported by Gilliland and Venard [49], and McCoy and Canonico [50].

Gilliland and Venard produced and tested welds in 1-in.-thick plates of 16 commercial heats of Hastelloy $\mathrm{N}$. They examined both the as-welded and the stress-relieved conditions $(2 \mathrm{~h}$ at $1600^{\circ} \mathrm{F}$ ). Tests, including tensile, creep-rupture, and hot ductility, were conducted on $1 / 4$-in.-diam. specimens machined from the weldments in the transverse (cross-weld) orientation. The reduced section of the tensile and creep specimen was $1 \frac{1}{4}$ in., and the weld metal and HAZ made up about half of the reduced section. The crosshead rate for tensile testing was $0.05 / \mathrm{min}$. Comparisons with the tensile data on the mill-annealed wrought heats are shown in Figure 20 through Figure 22 for the yield strength, UTS, and elongation, respectively. As might be expected, the yield strength for the as-welded materials was well above the yield strengths for the base metals. Specimens from the stress-relieved materials exhibited yield strengths closer to those of the base metals. The UTSs fell below those of the base metals in a temperature range from RT to $1200^{\circ} \mathrm{F}$. The stress-relief treatment was not very effective in improving the UTS or ductility. Generally, the failures of the as-welded specimens were in the weld metal, and those of the stress-relieved specimens were in either the weld metal or the base metal. At the same time, 
ductility was much reduced. These authors [49] also mention that the reduced ductility might be associated with the different specimen orientations used in the welds.

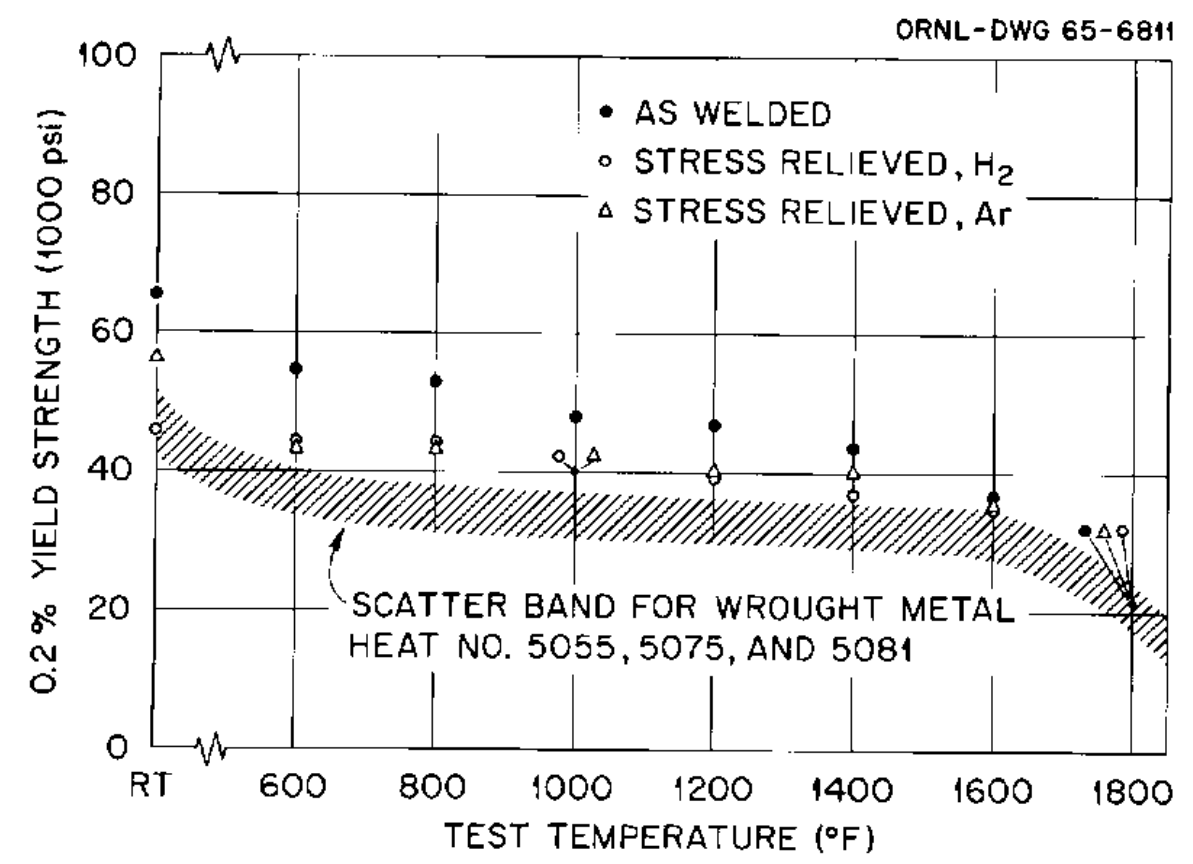

Figure 20 Comparison of the yield strengths for weldments of Hastelloy $\mathrm{N}$ with those of the base metal. Reproduced from Ref. [49].

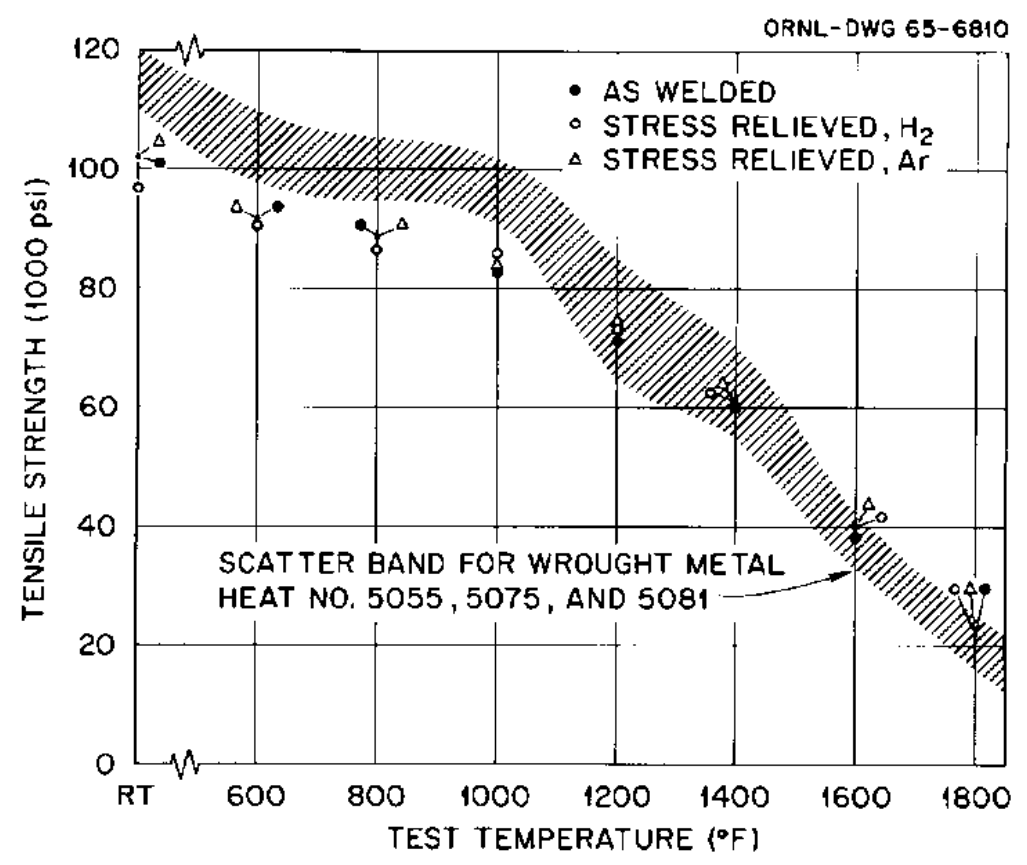

Figure 21 Comparison of the ultimate tensile strengths for weldments of Hastelloy $\mathbf{N}$ with those of the base metal. Reproduced from Ref. [49]. 


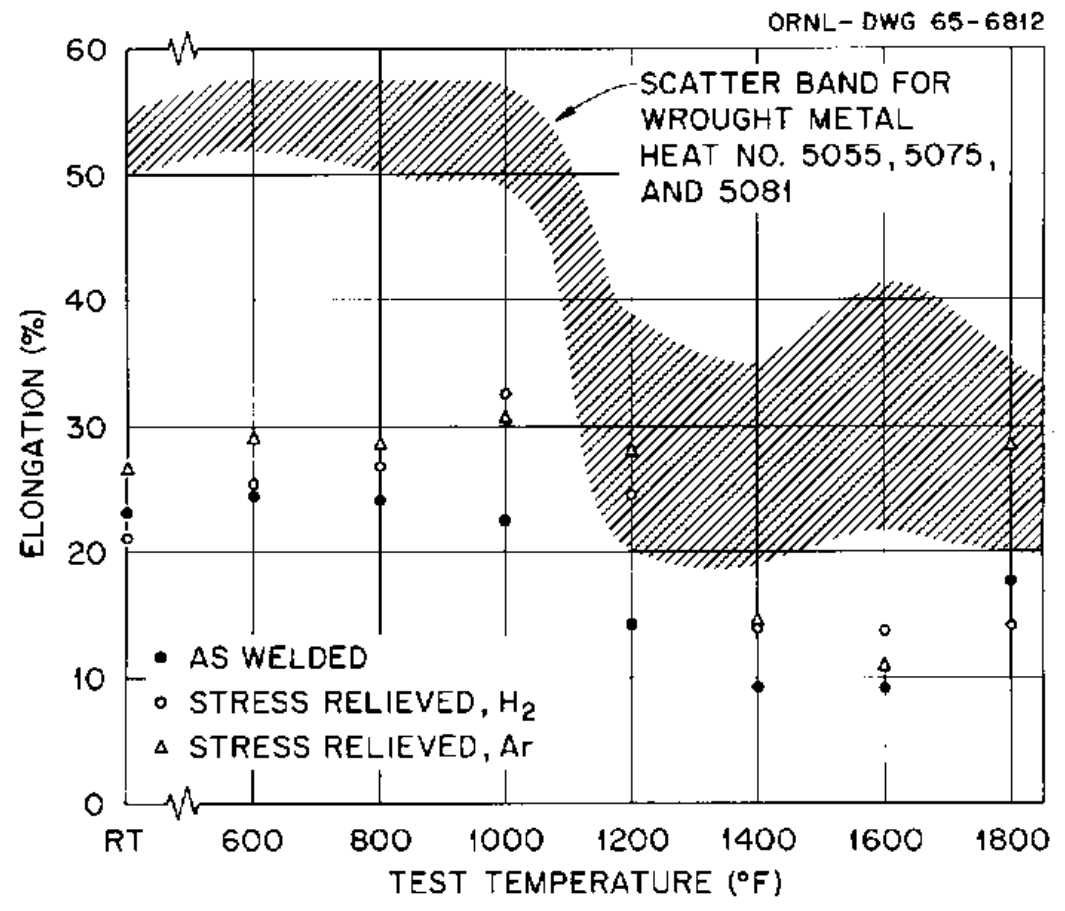

Figure 22 Comparison of the tensile elong ation for weldments of Hastelloy $\mathrm{N}$ with those of the base metal. Reproduced from Ref. [49].

The data produced by McCoy and Canonico [50] were from RT to $1600^{\circ} \mathrm{F}$. The RT ultimate strengths for 14 welds ranged from 108 to $126 \mathrm{ksi}$ and averaged $118 \mathrm{ksi}$. At $1200^{\circ} \mathrm{F}$ the range was 64.8 to $91.4 \mathrm{ksi}$ and the average was $80.7 \mathrm{ksi}$. These values were substantially greater than values found by Gilliland and Venard [49]. In general, the responses of the welds' tensile properties as a function of temperatures were similar to those obtained by Gilliland and Venard.

\subsubsection{Creep rupture and MCR of welds}

Gilliland and Venard [46] performed creep-rupture tests on Hastelloy N weldments to $1000 \mathrm{~h}$ at three temperatures: 1100,1300 and $1500^{\circ} \mathrm{F}$. For the most part, the rupture data for weldments fell within the scatter bands for the three heats of base metal that were included, as shown in Figure 23. The stress-relieved weldments, $2 \mathrm{~h}$ at $1600^{\circ} \mathrm{F}$, tended to last longer than the as-welded material. It was also reported that the stress relief shifted the failure location from the base metal to the weld metal.

The MCR data are compared with the base metal trends in Figure 24. The MCRs for the weldments tend to be lower than the "average" for the base metals. Similar behavior was found for the stress-relieved weldment specimens at 1300 and $1500^{\circ} \mathrm{F}$ (not shown), whereas weldment data at $1100^{\circ} \mathrm{F}$ indicated higher creep rates. 
SCATTER BANDS - WROUGHT METAL RESULTS: HEATS 5055 , 5075,5081

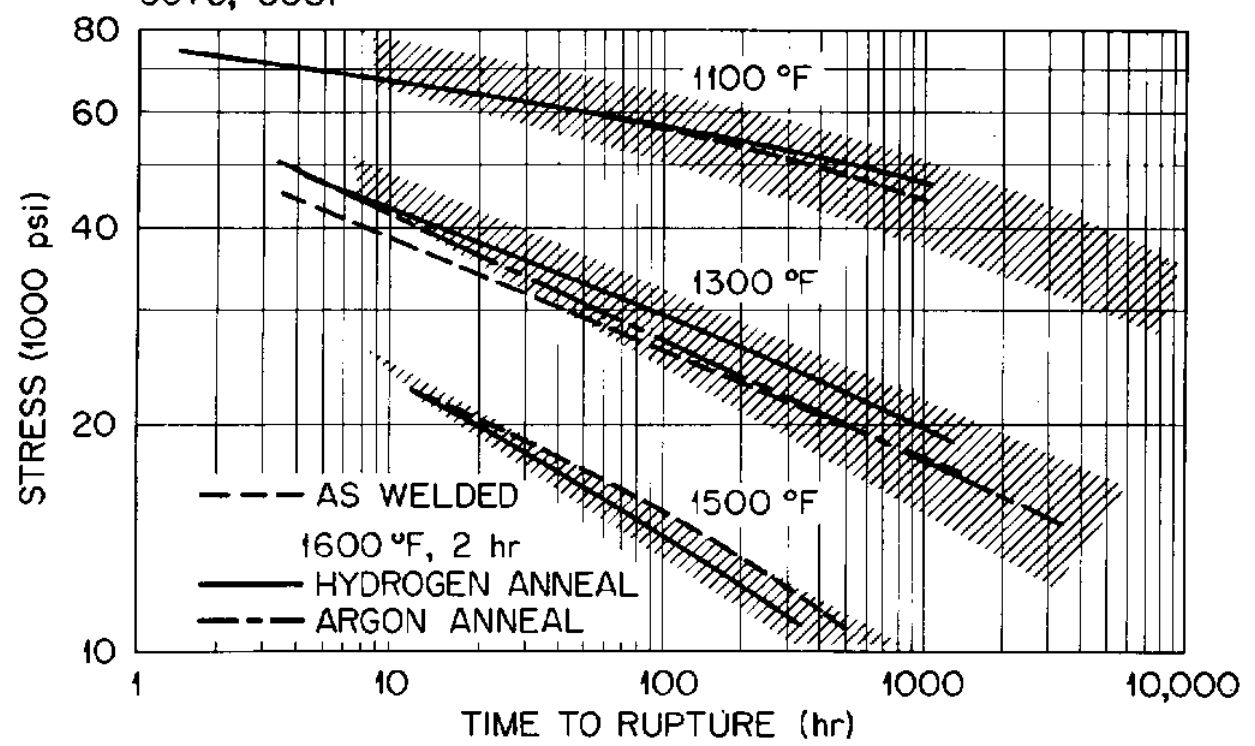

Figure 23 Trends for the stress -rupture of Hastelloy $\mathrm{N}$ welds compared with the scatter bands for base metal. Reproduced from Ref. [49].

ORNL-DWG 65-6815

DASHED LINES-WROUGHT METAL RESULTS: HEATS 5055, 5075, 5081

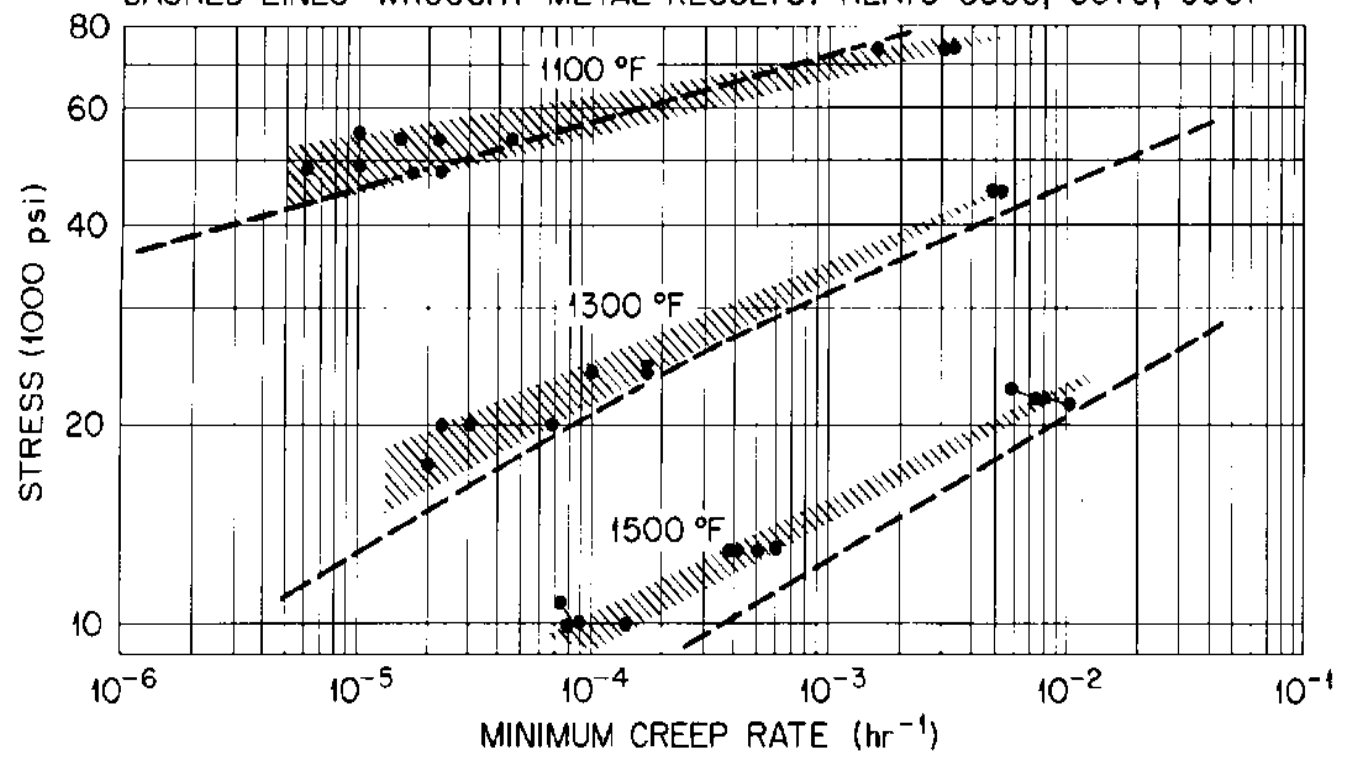

Figure 24 Minimum creep rate scatter bands of Hastelloy $\mathrm{N}$ welds compared with the trends for base metal. Reproduced from Ref. [49].

Stress-rupture data for weldments at $1200^{\circ} \mathrm{F}$ produced by McCoy and Canonico [50] had significant variability from one weldment to another, as shown in Figure 25 . The tests used small rod samples with a nominal gage diameter of 0.1248 in. The welds were made using the GTAW process in several heats, as shown in Table 15. 


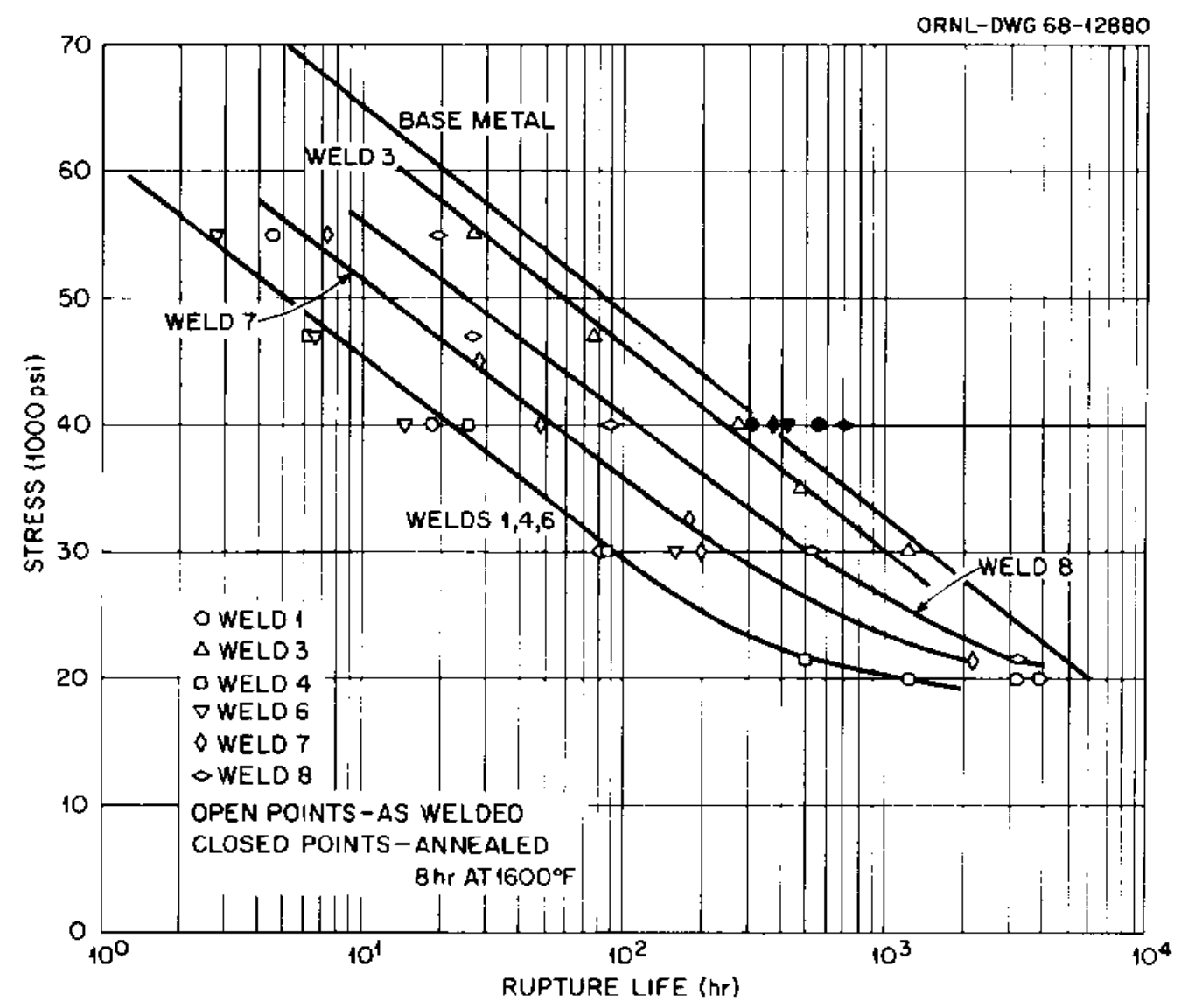

Figure 25 Stress-rupture of Hastelloy $\mathrm{N}$ welds at $1200^{\circ} \mathrm{F}$ compared with data for base metal. Reproduced from Ref. [50].

Table 15 Welds made in McCoy and Canonico study . Reproduced from Ref. [50].

\begin{tabular}{|c|c|c|c|}
\hline Weld number & Base metal $^{\mathrm{a}}$ & Filler metal & $\begin{array}{l}\text { Thickness of weld } \\
\text { (in.) }\end{array}$ \\
\hline 1 & 5065,5067 & 5101 & 1 \\
\hline 3 & 2477 & 2477 & $1 / 2$ \\
\hline 4 & 5065,5067 & 5101 & 1 \\
\hline 5 & 5065,5067 & 5055 & 1 \\
\hline 6 & 5065 & $65-552$ & $11 / 8$ \\
\hline 7 & 5065 & $5055+\mathrm{Al}_{2} \mathrm{O}_{3}{ }^{\mathrm{b}}$ & $11 / 8$ \\
\hline 8 & 5065 & $5055+W C^{b}$ & $11 / 8$ \\
\hline
\end{tabular}

aHeats $5065,5067,5101,5055$ were processed by air melting, 2477 and $65-552$ by vacuum melting. bFiller material was $1 / 8 \mathrm{in}$. wire of heat 5055 plasma sprayed with 0.002 in. of indicated material. 
All of the welds had lower creep-rupture strength in the as-welded condition than in the base metal. Weld 3, which involved only vacuum-melted materials, had significantly higher strength than the other welds. Welds 7 and 8 , which involved $\mathrm{Al}_{2} \mathrm{O}_{3}$ and $\mathrm{WC}$ additions, also showed notably better performance than welds 1,4 , and 6 .

The rupture lives of the welds approached those of the base metal as the stress level was reduced, likely as the result of thermal recovery of the weld metal during the long time at $1200^{\circ} \mathrm{F}$.

The strength was improved greatly by a post-weld anneal of $8 \mathrm{~h}$ at $1600^{\circ} \mathrm{F}$.

Many of the samples were examined using metallography. The structure of the base metal was characterized by stringers of $\mathrm{M}_{6} \mathrm{C}$-type precipitates and a relatively fine grain size. The weld metal contained a fine cellular structure within coarse grains. The fusion line was quite sharp, and the transition of some of the large $\mathrm{M}_{6} \mathrm{C}$ precipitates to a lamellar phase was apparent. The lamellar phase was reported by Gilliland to be an Mo-Ni-Si compound [48]. The same comments apply to the fusion zones of the other welds, except for welds 3 and 8 . The base metals in weld 3 were vacuum-melted. The precipitates were primarily of the $\mathrm{Mo}_{2} \mathrm{C}$ type, which were found to dissolve easily. So, little of the lamellar transformation product was seen at the fusion line. As weld 3 had a higher creep strength, it seems that the lamella structure was responsible for the lowered strength in other welds.

\subsubsection{Recent development $s$ in welding}

The microstructure of welds in Hastelloy $\mathrm{N}$ has attracted much attention recently because of its importance in understanding and controlling the mechanical properties of welds. In an effort involving an electro-probe microanalysis (EPMA), electron backscatter diffraction (EBSD), and Xray diffraction (XRD), Chen et al. [51] analyzed the precipitates of an as-welded joint of GH3535 or N10003 alloy. The primary precipitates in the base metal and eutectic precipitates in the HAZ and the weld metal were $M_{6} C$ type, even though they appeared in different morphologies. The hardness value of the HAZ (eutectic zone) was significantly higher than in the rest of the joint. Tensile tests suggested the welded joints had very stable mechanical performance at elevated temperatures from 650 to $725^{\circ} \mathrm{C}$. All the tensile samples were fractured in the base metal, indicating that the eutectic carbides have no adverse effects on the short-time mechanical performance of the joints. The fine carbides, which contributed dispersion strengthening in the weld metal, were the main contributor to enhancing the hardness and strength of the welds.

In the TMSR, the sleeve of the control rod generally allows very little post-weld deformation. Traditional GTAW could not satisfy such a requirement because of the large size of the fusion zone (FZ) and the large deformation resulting from the large heat input. Laser beam welding (LBW) is being considered as an alternative because of its high welding efficiency, small structural deformation, and narrow HAZ. In a recent study, Yu et. al. [52] investigated LBW of Hastelloy N or GH3535 and demonstrated that the tensile strength of joints made by LBW was increased by 90 $\mathrm{MPa}$ by a post-weld heat treatment (PWHT) process at $871^{\circ} \mathrm{C}$ for $6 \mathrm{~h}$; elongation of the joints was increased accordingly.

In another study, Yu et al. investigated GMAW made in N10003 alloy [53]. GMAW has high deposition efficiency and can be an alternative to GTAW, but it involves high heat input and long retention times. The investigation revealed that chain-like dark dots exist in both the grain boundary and the grain interior in the FZ. These dark dots were considered to be $\mathrm{M}_{6} \mathrm{C}-\gamma$ eutectic carbides. The microstructure in the fusion boundary in the HAZ was transformed. The eutectic precipitates in the HAZ $(10 \mu \mathrm{m})$ were larger than in the FZ $(2 \mu \mathrm{m})$. Although the elements 
exhibited segregation behavior during the welding cycle, there was no solidification cracking in FZ of the N10003 alloy. The tensile strengths of the welded joints were similar to that of the base metal. So, $\mathrm{M}_{6} \mathrm{C}-\gamma$ eutectic carbides in the HAZ were not detrimental to the tensile properties of joints. The effect of precipitates on the creep strength of the joints has not been studied yet.

Local changes in the composition and structure of the weld joint due to fusion welding affect the corrosion process [54]. For materials in molten fluorides, material corrosion is influenced by the composition gradient through diffusion. Thus, composition changes across the weld will have an impact on the corrosion performance. Corrosion tests of weld joints of Hastelloy N10003 made by GTAW were performed by Zhu et al. [55] The salt was a eutectic LiF-NaF-KF molten salt with $46.5,11.5$, and $42 \mathrm{~mol} \%$, respectively, commonly referred as FLiNaK. The tests were conducted at 550,700 , and $850^{\circ} \mathrm{C}$ for $400 \mathrm{~h}$. The joints exhibited $\mathrm{Cr}$ depletion and iron enrichment in the corrosion layer, especially at 700 and $850^{\circ} \mathrm{C}$. The thickness of the $\mathrm{Cr}$-depleted layer induced by the corrosion in the molten salt increased with temperature. The grains of the alloy sample became coarser as a result of the annealing at higher temperature, which may also have enhanced the corrosion of the alloy in the salt. Hou et al. [56] investigated the effects of exposure duration on the corrosion performance of a similar weld joint in FLiNaK molten salt. It was revealed that the corrosion rate increased rapidly for a short-term duration of up to $400 \mathrm{~h}$ and then slowed down to a plateau for a long-term duration of up to $3000 \mathrm{~h}$.

Sabharwall et al. [57] studied corrosion in joints made in Hastelloy $\mathrm{N}$ and 242 alloys by diffusion welding. Hastelloy $\mathrm{N}$ and 242 were found to be weldable by diffusion welding, with UTSs about $90 \%$ of those of the base metal values. Both diffusion welds and sheet material in Hastelloy $\mathrm{N}$ were corrosion tested in $58 \mathrm{~mol} \% \mathrm{KF}$ and $42 \mathrm{~mol} \% \mathrm{ZrF} 4$ at 650,700 , and $850^{\circ} \mathrm{C}$ for 200, 500, and $1,000 \mathrm{~h}$. Corrosion rates were similar between welded and unwelded materials, typically less than $100 \mu \mathrm{m}$ per year after 1000-h corrosion tests. For materials of construction, Ni-based alloys and alloys with dense $\mathrm{Ni}$ coatings were effectively inert to corrosion in fluorides but not in chlorides. Hence, these authors suggested that additional testing of selected alloys for resistance against intergranular corrosion is needed.

\subsubsection{Joining for reactor components}

The reliability of tube-to-shell joints for $\mathrm{HX}$ applications in molten-salt systems is critical. The means of ensuring this reliability, welding and brazing, were successfully developed and tested extensively under severe operation conditions for the Aircraft Nuclear Propulsion Project [58]. The techniques was further improved and adapted for use in the fabrication of the primary $\mathrm{HX}$ for the MSRE [59].

The incorporation of a variety of components in a reactor system frequently requires the use of dissimilar-metal welds. Welding procedures have been developed for joining Hastelloy $\mathrm{N}$ to several different materials, including Inconel 600, austenitic SSs, and Ni [39].

\subsection{Gaps in Understanding}

\subsubsection{Advanced alloys for MSR}

It is known that the fuel and coolants for FHRs are suitable for operation at temperatures well above the upper temperature limits of available structural alloys. A limiting factor in achieving the highest possible FHR core outlet temperatures and thus thermal efficiency is the availability of structural alloys having sufficient creep strength at the required temperatures, along with suitable fluoride salt chemical compatibility. Hastelloy $\mathrm{N}$ uses solid solution strengthening and some 
carbide strengthening (through $\mathrm{M}_{6} \mathrm{C}$ ) as the primary strengthening mechanisms. These limit the strength and creep resistance at high temperatures and restrict its usefulness to temperatures less than about $704^{\circ} \mathrm{C}$. Components such as secondary $\mathrm{HXs}$ need to withstand large pressure differences between the salt side and the gaseous side. Such components need materials with high-temperature strength greater than that of Hastelloy $\mathrm{N}$, along with good resistance to salt, good oxidation resistance, and tolerance to nuclear irradiation.

Holcomb et. al. [60] recently developed a new series of alloys that depend on solid solution strengthening but are Co-free and have more tolerance against irradiation. The new alloys use $\mathrm{Mo}, \mathrm{Ta}, \mathrm{W}, \mathrm{Re}$, and Ru to provide solution strengthening and to decrease the interdiffusion coefficient in the matrix. The creep rupture life improves to as high as $1,000 \%$, with some increased corrosion rates in FLiNaK being $\sim 3-8$ times that of Hastelloy $\mathrm{N}$.

Another series of alloys were developed recently, also by Holcomb et al. [61]. The primary strengthening in the new alloys is achieved through the precipitation of coherent $\gamma$ ' precipitates, along with solid solution strengthening. A small amount of carbides is also present to prevent grain boundary sliding. In these alloys, small amounts of $\mathrm{Al}, \mathrm{Ti}$, and $\mathrm{Nb}$ are added to form $\gamma^{\prime}$ precipitates (Table 16). Tantalum and tungsten are added for additional solid solution strengthening. Co is eliminated. The tensile strengths of the new alloys at $850^{\circ} \mathrm{C}$ are much higher than those of Hastelloy $\mathrm{N}$ with an improvement of $66-87 \%$ in tensile strengths at $850^{\circ} \mathrm{C}$. Creep rupture life was measured in the aged condition at $850^{\circ} \mathrm{C}$ at a stress level of $12 \mathrm{ksi}$ in an inert atmosphere; the new alloys showed improvements in rupture lives of greater than $10,000 \%$. These alloys were tested in $\mathrm{FLiNaK}$ at $850^{\circ} \mathrm{C}$ for $1000 \mathrm{~h}$. The results demonstrate that they have slightly high corrosion rates, about 4-14 times that of Hastelloy N.

In another effort, Muralidharan et al. [62] developed new alloys primarily strengthened through carbides. Computational design was used to ensure that the formation of brittle intermetallic phases in the new alloys is very low or $0 \mathrm{wt} \%$ in the operating temperature range of 750 to $950^{\circ} \mathrm{C}$. In these alloys, small amounts of carbide formers, such as $\mathrm{Ti}, \mathrm{Nb}$, and $\mathrm{Ta}$, are added; and the carbon levels are increased compared with Hastelloy N. Creep rupture life was measured in the solution-annealed condition at $850^{\circ} \mathrm{C}$ at a stress level of $12 \mathrm{ksi}$ and showed improvement of more than $100,000 \%$. These new alloys were also tested in FLiNaK at $850^{\circ} \mathrm{C}$ for $1000 \mathrm{~h}$. The results showed them to have slightly higher corrosion rates, about 6-32 times that of Hastelloy N.

Table 16 Compositions of new $\gamma^{\prime}$ strengthened alloys, wt \%. Reproduced from Ref. [61].

\begin{tabular}{|llllllllllllll|ll|}
\multicolumn{1}{c}{ Alloy } & \multicolumn{1}{c}{$\mathbf{N i}$} & $\mathbf{F e}$ & $\mathbf{A l}$ & $\mathbf{C o}$ & $\mathbf{C r}$ & $\mathbf{M n}$ & $\mathbf{M o}$ & $\mathbf{T i}$ & $\mathbf{N b}$ & $\mathbf{T a}$ & $\mathbf{W}$ & $\mathbf{C}$ & $\mathbf{B}$ & $\mathbf{N}$ & Total \\
\hline Hastelloy $\mathrm{N}^{*}$ & 68.7 & 5 & $* *$ & 0.2 & 7 & 0.8 & 16 & $* *$ & 0 & 0 & 0.5 & 0.08 & 0.01 & & 100 \\
Alloy 7 & 76.211 & 0.01 & 1.3 & 0 & 6.57 & 0.76 & 11.76 & 2.84 & 0.01 & 0 & 0.51 & 0.029 & 0.0005 & 0.0005 & 100 \\
Alloy 8 & 76.649 & 0.01 & 1.23 & 0 & 6.56 & 0.74 & 11.78 & 2.43 & 0.01 & 0 & 0.56 & 0.031 & 0 & 0.0003 & 100 \\
Alloy 11 & 76.0369 & 0.01 & 1.73 & 0 & 6.53 & 0.76 & 10.92 & 3.41 & 0.01 & 0 & 0.56 & 0.032 & 0.0004 & 0.0007 & 100 \\
Alloy 71 & 75.2616 & 0.01 & 1.26 & 0 & 6.98 & 0.75 & 10.06 & 2.97 & 0.23 & 1.95 & 0.49 & 0.037 & 0.0003 & 0.0011 & 100 \\
Alloy 72 & 75.6536 & 0 & 1.48 & 0 & 6.88 & 0.73 & 9.86 & 2.94 & 0 & 1.94 & 0.48 & 0.036 & 0.0003 & 0.0001 & 100 \\
Alloy 73 & 75.8728 & 0.01 & 0.98 & 0 & 6.85 & 0.77 & 9.62 & 2.94 & 0.22 & 2.2 & 0.5 & 0.036 & 0.0003 & 0.0009 & 100 \\
Alloy 74 & 72.5641 & 0 & 1.84 & 0 & 7.05 & 0.75 & 10.25 & 0.99 & 0.22 & 5.82 & 0.48 & 0.035 & 0.0005 & 0.0004 & 100 \\
\hline
\end{tabular}

*Hastelloy $\mathrm{N}$ also contains $1 \mathrm{Si}, 0.35 \mathrm{Cu}$; $\mathrm{N}$ content is unknown.

${ }^{* *} \mathrm{Al}+\mathrm{Ti}<0.35 \%$ 
At Russian Research Center-Kurchatov Institute, the Ni-based alloy HN80MTY was studied as an alternative to Hastelloy N. Also refer to chapters 2.4.3 and 3.2.1 in this report for more information. The chemical composition of HN80MTY in wt \% is Mo-13, Cr-6.8, Al-1.1, Ti-0.9 [63]. A series of corrosion tests was conducted on HN80MTY and several other alloys, including HN80M-VI (Mo-12, Cr-7.6, Nb-1.5), HN80MTW (Mo-9.4, Cr-7.0, Ti-1.7, W-5.5) and EM-721 (Cr5.7, Ti-0.17, W-25.2) [64, 65]. The molten $\mathrm{LiF}_{-} \mathrm{BeF}_{2}$ salt mixture contains about $20 \mathrm{~mol} \%$ of ThF $2 \mathrm{~mol} \%$ of $\mathrm{UF}_{4}$, and additives of $\mathrm{Cr}_{3} \mathrm{Te}_{4}$. Five cycles were used with $250 \mathrm{~h}$ of exposure time each at $725-750^{\circ} \mathrm{C}$ under mechanical loading from 0 to $25 \mathrm{MPa}$. The [U(IV)]/[U(III)] ratio in the fuel salt varied from 0.7 to 500 . HN80MTY specimens were found to have the best resistance to Te intergranular cracking. HN80MTY was recommended as the construction material for the MOSART and Molten Salt Fast Reactor primary circuits with selected fuel salts up to a temperature of $750^{\circ} \mathrm{C}[66]$.

MoNiCr alloy is another Ni superalloy candidate in modern concepts of nuclear reactors in which molten fluoride salts are used in the primary and/or secondary circuits. The chemical composition of this alloy is quite similar to that of Hastelloy $\mathrm{N}$ and is measured in wt \% as Mo-15.8, Cr-6.8, Fe2.3. It has high corrosion resistance against fluoride salts and very good creep properties in the temperature range between 650 and $800^{\circ} \mathrm{C}$ [67]. The formation conditions for MoNiCr were tested to obtain conditions for good dynamic recrystallization during hot forming and material formability. The results showed that the warm strength of the alloy was very high. Even at $1200^{\circ} \mathrm{C}$, it exceeded $100 \mathrm{MPa}$, while the uniform elongation up to the maximum stress was low. With better formability and lower production costs, $\mathrm{MoNiCr}$ is considered one of the most promising candidates for the Acceleration Driver Transmutation Technology reactors.

The creep behavior and high-temperature corrosion in molten fluoride salts of two experimental $\mathrm{Ni}$ alloys (MoNiCr type) and a comparative alloy (Hastelloy B type) have been investigated [68]. The creep tests were performed at $700^{\circ} \mathrm{C}$ in a stress range from 80 to $160 \mathrm{MPa}$. The creep resistance of alloy $\mathrm{B}$ was better than that of MoNiCr. Corrosion tests were performed within a molten mixture of $\mathrm{NaF}$ and $\mathrm{LiF}$ in a nitrogen/ $5 \%$ hydrogen atmosphere at $710^{\circ} \mathrm{C}$ for $320 \mathrm{~h}$. The results showed that mass gains of alloy MoNiCr were comparable to those of alloy $\mathrm{B}$.

More corrosion tests on MoNiCr nickel specimens in a molten salt environment were reported in 2015 [69]. All tests were conducted at $700^{\circ} \mathrm{C}$ in an inert atmosphere of nitrogen. The assessment of corrosion damage suggested that in the $\mathrm{LiF}_{-}-\mathrm{BeF}_{2}$ melt at $700^{\circ} \mathrm{C}, \mathrm{Cr}$ and Mo were preferentially released into the melt and the surface and grain boundaries became depleted of $\mathrm{Cr}$. Particles with elevated levels of $\mathrm{Mo}$ and $\mathrm{Cr}$ were found on grain boundaries. With the results from corrosion and irradiation tests on MoNiCr alloys, COMTES FHT Company has reached experimental pilot production of $\mathrm{MoNiCr}$ (ingots, sheets, wires, tubes) [70], and further tests of high-temperature microstructure stability, high-temperature mechanical stability, and radiation embrittlement will be conducted [71].

EM-721 (W-25.2, Cr-5.7, Ti-0.17 wt \%) is another nickel- based alloy, developed in France for the GEN IV MSR [72]. The corrosion resistance of EM-721 was studied along with that of HN80M-VI, HN80MTY, and HN80MTW [65]. All alloys, except EM-721, had noticeable ductility in mechanical tests both before and after corrosion tests. In the EM-721 specimens, brittle destruction was clearly observed, both in their initial state and after corrosion testing; the destruction was caused by heterogeneity of structure due to the tungsten phase. The presence of such a phase increased intergranular corrosion and led to reduction of the alloy's resistance to Te damage.

The Hastelloy N equivalent GH3535 was developed in China [73, 74]; the activities related to its welding are discussed in previous section. For some new Ni-based alloys, the use of carbide 
dispersion is being considered to improve strength-for example, the NiMo-based dispersionprecipitation-strengthened (DPS) SiC composite under development for use in the future generation of MSRs [75]. The improvement of mechanical properties and the evolution of microstructure have reached the design expectations. However, it has been shown that the ductility of these materials is reduced in comparison with $\mathrm{Ni}-\mathrm{SiC}$ composites. Further stressrupture tests and corrosion tests are needed to enable better evaluation of these kinds of NiMobased SiC composites in MSR applications.

Although there are alloy development efforts for MSR applications worldwide, a systematic evaluation of these alloys is not available. For an MSR design concept, a comprehensive property evaluation of candidates is needed so that the alloy with the best performance can be identified, codified, and further approved.

\subsubsection{Cladding or lining}

To combine the advantages of SS 316 and Hastelloy N, the use of SS 316 or $800 \mathrm{H}$ with Hastelloy $\mathrm{N}$ or pure nickel as a cladding can be an option. The option may be an intermediate solution to avoid the time-consuming ASME BPVC qualification process. Cold-spray supersonic impingement of Hastelloy $\mathrm{N}$ or nickel on a base metal may be possible. However, the adhesion/compatibility at high temperatures between cladding and substrate must be investigated.

A similar option is used in the AHTR preconceptual design for the reactor vessel, which calls for the use of an Incoloy $800 \mathrm{H}$ vessel with a thick $(1 \mathrm{~cm})$ nickel or Hastelloy $\mathrm{N}$ lining. The lining provides corrosion protection for the reactor vessel from the primary salt and is not credited for any structural strength. The design intent for a thick $(1 \mathrm{~cm})$ liner is to provide sufficient liner thickness that material performance issues arising from solid state inter-diffusion do not become life-limiting. The lining is likely to be applied as a welded-on layer. However, Division 5 of ASME BPVC Section III currently has only limited, structurally focused design rules (NH-3227.8 and NB3122) for welded-on liners.

\subsubsection{Database for Hastelloy N}

The current pathway to codify alloys for MSR use is still unclear. However, a feasible goal for the near term may include Hastelloy N in ASME BPVC Section III-5. The existing database can be used to initiate the ASME code case to include the subject alloy in Section III-5 for the construction of Class B components. However, the database is not large enough to include the material for construction of Class A components. The procedure used in ongoing Alloy 617 Code Case and Alloy 709 Code Case projects sponsored by the DOE Nuclear Energy program can serve as a guideline for the data package development for Hastelloy N. One critical item that controls the Code Case project is the creep rupture data to $100,000 \mathrm{~h}$ used to extrapolate the allowable stresses at 500,000 h. In addition, the allowable stresses for service loadings need the full creep curve for estimating the times at $1 \%$ creep strain and initiation of tertiary creep. The development of the data package is more demanding than the development of the Code Case for ASME BPVC Section I; and instrumentation thus needs to be carefully designed, fabricated, and calibrated.

To support the Code Case, environmentally assisted creep rupture needs to be investigated. The creep rupture of Hastelloy $\mathrm{N}$ in salt was studied previously. But the lifetimes were less than 13,000 h. In addition, the creep tests were generally conducted in static salt. The response of creep rupture in a flow salt condition is not known. A new test protocol needs to be developed to characterize the effect of the salt on creep rupture over the long term. 


\subsubsection{Lifetime prediction}

Current lifetime prediction methods such as LMP analysis are based on empirical assumptions [11]. However, such analyses need to be confirmed in greater detail. Advanced computation approaches need to be introduced and incorporated into the research to justify the five-fold extrapolation of creep rupture times. The computation will need to consider the inherent diffusion mechanisms related to the creep process and calibrate against the experimental data in various temperatures or environments [76].

\subsection{Recommendations}

This report provides an overview of the main mechanical properties data, including those produced in the development of the MSRE. Other aspects of the developmental work could be helpful in developing the data needs for a Code Case to qualify the material under the rules of ASME BPVC Section III, Division 5. Two important considerations with respect to the use of Hastelloy $\mathrm{N}$ as a structural material in MSRs, of course, are the irradiation resistance and the corrosion behavior. These issues have been reviewed in several references [10,76-79] and in Chapters 2 and 3 of the report.

\subsubsection{Inclusion of Hastelloy $\mathbf{N}$ into Section III -5 for construction of Class B components}

Although there is a concern regarding the performance of Hastelloy $\mathrm{N}$ under irradiation and high temperature, it is the leading material for test FHRs. For the case where irradiation does not present a direct threat such as Class $B$ components, Hastelloy $N$ is still one of the best options available. The codification of this material could provide an immediate solution to the urgent material need in current MSR development. There is a substantial existing body of knowledge for Hastelloy N, and a relatively low level of effort would be necessary for limited-term qualification of Hastelloy N. A more detailed study of the references provided in this report will be required in establishing a Code Case to qualify Hastelloy $\mathrm{N}$ for construction of Class $\mathrm{B}$ components under the rules of ASME BPVC Section III, Division 5 [24].

Here are some recommendations, with special attention to the codification of Hastelloy N:

1. The existing tensile data are adequate to establish the time-independent allowable stresses under the rules of ASME BPVC Section VIII, Division 1, that are referenced in Section III, Division 5 for Class B components.

2. The recommended values for $S_{U}$ and $S_{Y}$ may be used to include Hastelloy $N$ in Tables HGB-II-3229-3 and HGB-II-3229-6, if necessary, to extend temperatures to $1300^{\circ} \mathrm{F}$ [24].

3. The current time-dependent allowable stresses in ASME BPVC Section II, Part D, Table $1 \mathrm{~B}$, are conservative relative to the data produced from commercial plate products; and they are representative of other sheet and plate products except at $1100^{\circ} \mathrm{F}$ and below where the Table 1B values appear to be slightly higher. No changes in Section II, Part D, Table 1B, are recommended; but new values will be needed in the 1050 to $1150^{\circ} \mathrm{F}$ range if a "high stress" line is added to the table.

4. Data pertaining to the effect of aging on subsequent creep-rupture were examined by McCoy [32] and found to be of minimal importance. As part of the additional work, 
consideration should be given to adding Hastelloy N to Table HCB-II-2000-5, Reduction Factors for Aging, along with justification for the values.

5. Hastelloy N should be added to Table HCB-II-3000-4, Allowable Stress Values for HighNickel Alloy Class B Components [24].

6. For Table HCB-II-2000-4, Allowable Stress Values for High-Nickel Alloy Class B Components, effort could be made to develop allowable stresses meeting the criteria for this table for Hastelloy N [24].

7. The establishment of the maximum number of cycles and the stress range reduction factor for piping (HCB-1) were not discussed. However, careful consideration of the high-cycle rotating beam data could be of benefit in making some initial estimates for Table HCB-I2000-2 and Table HGB-II-3222.4-x in the $10^{5}$ to $10^{6}$ cycle range [24].

8. Further testing is needed to establish the strain-fatigue behavior of Hastelloy $\mathrm{N}$.

\subsubsection{Codification of advanced alloys for MSR s}

Qualification of high-strength alloys can reduce the capital investment by using thin vessels and piping, enhancing the efficiency of thermal conversion, and raising the safety margin. Use of highstrength alloys that enable a higher permit temperature can enhance the outlet of the primary coolant and thus increase the overall efficiency of an MSR. Use of high-strength alloys can eliminate the bi-metal joining in the secondary HXs. To codify advanced alloy(s) for MSR use, first, a screening process will be required to identify the best candidate for the construction of Class A components. Then the code case plan will be developed. The testing facilities will be prepared and a Code Case project executed to have the data package developed and made ready for the review of related ASME BPVC committee.

\subsection{References}

[1] P.N. Haubenreich and J.R. Engel, Experience with the Molten-Salt Reactor Experiment, Nuclear Applications \& Technology 8, 118-136, 1970.

[2] V.K. Varma, D.E. Holcomb, F.J. Peretz, E.C. Bradley, D. Ilas, A.L. Qualls, and N.M. Zaharia, AHTR Mechanical, Structural, and Neutronic Preconceptual Design, ORNL/TM-2012/320, Oak Ridge National Laboratory, 2012.

[3] D.E. Holcomb, F.J. Peretz, A.L. Qualls, Advanced High Temperature Reactor Systems and Economic Analysis, ORNL/TM-2011/364, Oak Ridge National Laboratory, 2011.

[4] C.H. Andreades, A.T. Cisneros, J. K.Choi, A.Y.K. Chong, M. Fratoni, S. Hong, L.R. Huddar, K.D. Huff, D.L. Krumwiede, M.R. Laufer, M. Munk, R.O. Scarlat, N. Zweibaum, E. Greenspan, and P.F. Peterson, Technical Description of the "Mark 1" Pebble-Bed Fluoride-Salt-Cooled High-Temperature Reactor (PB-FHR) Power Plant, UCBTH-14002, University of California, 2014.

[5] C. Forsberg, L.-W. Hu, J. Richard, R. Romatoski, B. Forget, J. Stempien, R. Ballinger, K. Sun, and D. Carpenter, Fluoride-Salt-Cooled HighTemperature Test Reactor (FHTR): Goals, Options, Ownership, Requirements, Design, Licensing, and Support Facilities, MIT-ANP-TR-154, Massachusetts Institute of Technology, 2014.

[6] R. Xie, Progress of materials R\&D in TMSR Project, Molten Salt Reactor Workshop 2016, Oak Ridge, Tennessee, 2016. 
[7] Idaho National Laboratory, High Temperature Materials Performance, HTGR Technology Course for the Nuclear Regulatory Commission, 2010.

[8] R.M. Meyer, P. Ramuhalli, B.G. Braatz, and S.R. Doctor, Application of Acoustic Emission and Other Online Monitoring Technologies to High Temperature Gas Reactors, PNNL-20606, Pacific Northwest National Laboratory, 2012.

[9] P. Sabharwall, J. Collins, D. Clark, A. Siahpush, W. Phoenix, M. McKellar, and M. Patterson, Technology Development Roadmap for the Advanced High Temperature Reactor Secondary Heat Exchanger, INL/EXT-12-26219, Idaho National Laboratory, 2012.

[10] W. Ren, G. Muralidharan, D.F. Wilson, and D.E. Holcomb, Considerations of Alloy N for fluoride salt-cooled high-temperature reactor applications, ASME 2011 Pressure Vessels \& Piping Division Conference, Baltimore, Maryland, USA, 2011, pp. PVP201157029.

[11] R.W. Swindeman, Identification of materials data needs to qualify Hastelloy $\mathrm{N}$ alloy for nuclear components in elevated temperature service, Cromtech Inc, 2012.

[12] T. Allen, M. Anderson, R. Ballinger, T. Burchell, E. Blandford, D. Clark, W. Corwin, G. Flanagan, C.s. Forsberg, P. Hosemann, D. Holcomb, L.-W. Hu, J. Hunn, and V. Ignatiev, Fluoride-Salt-Cooled High Temperature Reactor (FHR) Materials, Fuels and Components White Paper, UCBTH-12-003, University of Wisconsin, Madison, 2013.

[13] D.E. Holcomb, G.F. Flanagan, G.T. Mays, W.D. Pointer, K.R. Robb, and G.L. Yoder, Jr., Fluoride Salt-Cooled High-Temperature Reactor Technology Development and Demonstration Roadmap, ORNL/TM-2013/401, Oak Ridge National Laboratory, 2013.

[14] Haynes International, Hastelloy N Alloy, H-2052C, Haynes International, 2017. http://haynesintl.com/docs/default-source/pdfs/new-alloy-brochures/corrosion-resistantalloys/brochures/n-brochure.pdf?sfvrsn=18 (accessed December 2018)

[15] Haynes International, Nickel-molybdenum-chromium-iron alloy as material for ASME boiler and pressure vessel construction, Document 5537, Haynes International, 1961.

[16] Special Metals, The story of the "Incoloy alloys series, from 800 through $800 \mathrm{H}, 800 \mathrm{HT}$, Pub. No. SMC-046, Special Metals Corporation, 2004.

http://www.specialmetals.com/assets/smc/documents/alloys/incoloy/incoloy-alloy800.pdf (accessed December 2018.

[17] Australian Stainless Steel Development Association, 304: The place to start, 2017. https://www.assda.asn.au/technical-info/grade-selection/304-the-place-to-start (accessed December 2018).

[18] Australian Stainless Steel Development Association, 316: The first step up, 2017. https://www.assda.asn.au/technical-info/grade-selection/316-the-first-step-up (accessed December 2018)

[19] J.R. Keiser, J.H. Devan, and E.J. Lawrence, Compatibility of molten-salts with type-316 stainless-steel and lithium, J. Nucl. Mater. 85-6(Dec), 295-298, 1979.

[20] NGNP High Temperature Materials White Paper, NL/EXT-09-17187, Rev. 1, Idaho National Laboratory, 2012. https://art.inl.gov/NGNP/INL\%20Documents/Year\%202012/ NGNP\%20High\%20Temperature\%20Materials\%20White\%20Paper.pdf (accessed December 2018) 
[21] Haynes International, Haynes 230 Alloy, H-3000K, Haynes International, 2017. http://haynesintl.com/docs/default-source/pdfs/new-alloy-brochures/high-temperaturealloys/brochures/230-brochure.pdf (accessed December 2018)

[22] Haynes International, Haynes 242 Alloy, H-3079G, Haynes International, 2017. http://haynesintl.com/docs/default-source/pdfs/new-alloy-brochures/high-temperaturealloys/brochures/242-brochure.pdf?sfvrsn=10 (accessed December 2018)

[23] American Society of Mechanical Engineers, Boiler and Pressure Vessel Committee on Materials, 2017 ASME Boiler and Pressure Vessel Code, Section II Materials, Part D Properties, ASME, New York, 2017.

[24] American Society of Mechanical Engineers, Committee on Construction of Nuclear Facility Components, 2017 ASME Boiler and Pressure Vessel Code, Section III Rules for Construction of Nuclear Facility Components, Division 5 High-Temperature Reactors, ASME, New York, July 1, 2017.

[25] D.W. Schultz, Mechanical Properties of Wrought Haynes Developmental Alloy No. 8284, Project No. 816-3202-2, Haynes Stellite Co, 1958.

[26] R.W. Swindeman, The Mechanical Properties of INOR-8, ORNL-2780, Oak Ridge National Laboratory, 1961.

[27] D.A. Douglas and W.D. Manly, A Laboratory for High-Temperature Creep Testing of Metals and Alloys in Controlled Environments, ORNL-2053, Oak Ridge National Laboratory, 1956.

[28] J.T. Venard, Tensile and Creep Properties of INOR-8 for the Molten Molten-Salt Reactor Experiment, ORNL- TM- 1017, Oak Ridge National Laboratory, 1965.

[29] H.E. McCoy, Jr., An Evaluation of the Molten Salt Reactor Experiment Hastelloy N Surveillance Specimens-First Group, ORNL-TM-1997,Oak Ridge National Laboratory, 1967.

[30] H.E. McCoy, Jr., An Evaluation of the Molten-Salt Reactor Experiment Hastelloy N Surveillance Speximens-Second Group, ORNL-TM- 2359, Oak Ridge National Laboratory, 1969.

[31] H.E. McCoy, Jr., An Evaluation of the Molten-Salt Reactor Experiment Hastelloy N Surveillance Specimens-Third Group, ORNL-TM-2647, Oak Ridge National Laboratory, 1970.

[32] H.E. McCoy, Jr., An Evaluation of the Molten-Salt Reactor Experiment Hastelloy N Surveillance Specimens_Fourth Group, ORNL-TM- 3063, Oak Ridge National Laboratory, 1971

[33] H.E. McCoy, Jr., Effects of Irradiation on the Mechanical Properties of Two VacuumMelted Heats of Hastelloy N, ORNL- TM- 2043, Oak Ridge National Laboratory, 1968.

[34] Oak Ridge National Laboratory, Computation Materials Data Network, gen4devdb.ornl.gov (accessed December 2018).

[35] A.E. Carden, Thermal fatigue of a nickel-based alloy, Journal of Basic Engineering 87(1), 237-244, 1965.

[36] J.P. Hammond, Effect of Long-Term Aging at $815^{\circ} \mathrm{C}$ on the Tensile Properties and Microstructural Stability of Four Cobalt- and Nickel-Base Superalloys, ORNL -5174, Oak Ridge National Laboratory, 1976. 
[37] H.E. McCoy and J.R. Weir, Evaluation of Hastelloy N Tubes for Snap-8 Applications, ORNL-TM-1763, Oak Ridge National Laboratory, 1967.

[38] R.G. Carlson, Fatigue Studies of INOR-8, BMI-1354, Battelle Memorial Institute, 1959.

[39] H.E. McCoy, Jr. and J.R. Weir, Jr., Materials Development for Molten-Salt Breeder Reactors, ORNL-TM-1854, Oak Ridge National Laboratory, 1967.

[40] A.E. Carden, Thermal Fatigue_-An Analysis of the Experimental Method, Oak Ridge National Laboratory, ORNL-TM-405, Oak Ridge National Laboratory, 1963.

[41] A.E. Carden, Thermal Fatigue Evaluation, Manual on Low Cycle Fatigue Testing, STP 465, ASTM, Philadelphia, PA, 1970, pp. 163-188.

[42] R.B. Briggs, Design Fatigue Strength of Hastelloy-N, MSR-69-117, Oak Ridge National Laboratory, 1969.

[43] J.M. Corum, Explanation of Procedure Used to Evaluate the Effects of Cyclic Strains in the MSRE Pumps, in Thermal-Stress and Strain-Fatigue Analysis of MSRE Fuel and Coolant Pump Tanks, Appendix D, ORNL-TM-78, Oak Ridge National Laboratory, 1962.

[44] American Society of Mechanical Engineers, Nickel-Molybdenum-Chromium-Iron Alloy, Section VIII, Division 1, Code Case 1315-3, ASME, 1968.

[45] A.E. Carden, T. Moore, and E.E. Jungerman, Relaxation of Hastelloy-N (INOR) at $1300 F$, M. R. No. 24, Bureau of Engineering Research, University of Alabama, 1964.

[46] I. Roberts, Prediction of relaxation in metals, Proceedings/ Amerian Society for Testing Materials 51, 811-825, 1951.

[47] R.W. Swindeman, Unpublished data, Oak Ridge National Laboratory, 1961.

[48] R.G. Gilliland, Microstructures of INOR-8 Weldments, ORNL- 3870, Oak Ridge National Laboratory, 1965.

[49] R.G. Gilliland and J.T. Venard, Elevated-Temperature Mechanical Properties of Welds in a Ni-Mo-Cr-Fe Alloy, ORNL-TM-1341, Oak Ridge National Laboratory, 1966.

[50] H.E. McCoy and D.A. Canonico, Preirradiation and Postirradiation Mechanical Properties of Hastelloy N Welds, ORNL-TM-2483, Oak Ridge National Laboratory, 1969.

[51] S. Chen, X.-X. Ye, K. Yu, C. Li, Z. Li, Z. Li, and X. Zhou, Microstructure and mechanical properties of UNS N10003 alloy welded joints, Materials Science and Engineering: A 682, 168-177, 2017.

[52] K. Yu, Z. Jiang, B. Leng, C. Li, S. Chen, W. Tao, X. Zhou, and Z. Li, Effects of post-weld heat treatment on microstructure and mechanical properties of laser welds in GH3535 superalloy, Optics \& Laser Technology 81, 18-25, 2016.

[53] K. Yu, Z. Jiang, X. Shi, C. Li, S. Chen, Z. Li, W. Tao, and X. Zhou, Evaluation on microstructure and mechanical properties of welded joints by GMAW in UNS N10003 Alloy, ASME 2017 Pressure Vessels and Piping Conference, Waikoloa, Hawaii, USA, 2017, pp. PVP2017-65159.

[54] C. Garcia, M.P.d. Tiedra, Y. Blanco, O. Martin, and F. Martin, Intergranular corrosion of welded joints of austenitic stainless steels studied by using an electrochemical minicell, Corrosion Science 50, 2390-2397, 2008. 
[55] Y. Zhu, J. Hou, G. Yu, J. Qiu, S. Chen, and X. Zhou, Effects of exposing temperature on corrosion performance of weld joint of a Ni-Mo-Cr Alloy, Journal of Fluorine Chemistry 182, 69-75, 2016.

[56] J. Hou, G. Yu, C. Zeng, H. Ai, R. Xie, Y. Chen, X. Zhou, L. Xie, and J. Wang, Effects of exposing duration on corrosion performance in weld joint of Ni-Mo-Cr alloy in FLiNaK molten salt, Journal of Fluorine Chemistry 191, 110-119, 2016.

[57] P. Sabharwall, D. Clark, M. Glazoff, G. Zheng, K. Sridharan, and M. Anderson, Advanced heat exchanger development for molten salts, Nuclear Eng. \& Design 280, 42-56, 2014.

[58] G.M. Slaughter and P. Patriarca, Welding and Brazing of High-Temperature Radiators and Heat Exchangers, ORNL-TM- 147, Oak Ridge National Laboratory, 1962.

[59] R.G. Donnelly and G.M. Slaughter, Fabrication of the Molten-Salt Reactor Experiment heat exchanger core, Welding Journal 43, 118-124, 1964.

[60] D.E. Holcomb, G. Muralidharan, and D.F. Wilson, Creep-Resistant Cobalt-Free Alloys for High Temperature Liquid-Salt Heat Exchanger Systems, U.S. Patent (Ed.) USA, 2016.

[61] D.E. Holcomb, G. Muralidharan, and D.F. Wilson, High Strength Alloys for High Temperature Service in Liquid-Salt Cooled Energy Systems, U.S. Patent (Ed.) USA, 2017.

[62] G. Muralidharan, D.F. Wilson, and D.E. Holcomb, Intermediate Strength Alloys for High Temperature Service in Liquid-Salt Cooled Energy Systems, U.S. Patent (Ed.) USA, 2017.

[63] V. Ignatiev, O. Feinberg, S. Konakov, S. Subbotine, A. Surenkov, and R. Zakirov, Physical and chemical feasibility of fueling molten salt reactors with TRU's trifluorides, Proc. Intl. Conf. Back-end of the Fuel Cycle: From Research to Solutions, GLOBAL, 2001, p. 8.

[64] V. Ignatiev, V. Afonichkin, O. Feynberg, and A. Surenkov, Materials compatibility and salt chemistry control: Case for molten salt actinide recycler and transmuter, actinide and fission product partitioning and transmutation, Twelfth Information Exchange Meeting, 24-27 September, 2012, OECD 2013, Prague, Czech Republic, 2012, pp. 256-264.

[65] V. Ignatiev, A. Surenkov, I. Gnidoy, A. Kulakov, V. Uglov, A. Vasiliev, and M. Presniakov, Intergranular tellurium cracking of nickel-based alloys in molten $\mathrm{Li}, \mathrm{Be}, \mathrm{Th}$, U/F salt mixture, J. Nucl. Mater. 440(1-3), 243-249, 2013.

[66] V. Ignatiev, A. Surenkov, S. Abalin, I. Gnidoy, A. Kulakov, and V. Uglov, Nickel based alloys compatibility with fuel salts for molten salt reactor with thorium and uranium support, Structural Materials for Innovative Nuclear Systems (SMINS-3), Workshop Proceedings (7-10 October 2013), OECD 2015, 2015, pp. 71-80.

[67] Z. Novy, J. Džugan, P. Motycka, P. Podany, and J. Dlouhy, On formability of MoNiCr alloy, Advanced Materials Research 295-297, 1731-1737, 2011.

[68] J. Kasl, D. Jandová, T. Vlasák, J. Hakl, O. Brenner, and J. Cizner, Creep and corrosion resistance of Ni-alloys in molten NaF A LiF salt, MATERIALICA 09, Glasgow, 2009.

[69] P. Slama and M. Marecek, Corrosion testing of nickel alloy for molten salt reactors, J. of Achievements in Mater. and Manuf. Eng. 70(2), 78-85, 2015. 
[70] J. Uhlír, M. Straka, Z. Nový, and P. Svoboda, Current progress in R\&D on MSR and FHR technology and future directions, Technical Meeting on the Status of MSR Technology, IAEA, Vienna, Austria, 2016.

[71] J. Uhlír, M. Marecek, L. Szatmáry, Z. Nový, P. Toman, and J. Jílek, New Czech R\&D program on fluoride salt-cooled nuclear reactor systems, Transactions of the American Nuclear Society, San Francisco, California, pp. 1165-1166, 2017.

[72] Victor Ignatiev, GIF Reactor System development status: Molten salt reactor, 10th GIFINPRO IAEA Interface Meeting, Vienna, Austria, April, 112016.

[73] Y.-Q. Ji., S.-D. Qu, and W.-X. Han, Hot deformation and processing map of GH3535 superalloy, Trans. Nonferrous Metals Society of China 25, 88-94, 2015.

[74] F.F. Han, B.M. Zhou, H.F. Huang, B. Leng, Y.L. Lu, J.S. Dong, Z.J. Li, and X.T. Zhou, The tensile behavior of $\mathrm{GH} 3535$ superalloy at elevated temperature, Materials Chemistry and Physics 182, 22-31, 2016.

[75] C. Yang, O. Muránsky, H. Zhu, G.J. Thorogood, H. Huang, and X. Zhou, On the origin of strengthening mechanisms in Ni-Mo alloys prepared via powder metallurgy, Materials \& Design 113, 223-231, 2017.

[76] D. F. Williams, P. F. Britt, A. Navrotsky, M. Williamson, S. Bryan, S. Dai, B. DelCul, T. Nenoff, J. Keiser, P. Singh, B. Sumpter, B. Wirth, and C. Henager, Technology and Applied R\&D Needs for Molten Salt Chemistry, report of the Molten Salt Chemistry Workshop, April 10-12, 2017, pp.59-66.

[77] R. Swindeman, W. Ren, M. Katcher, and D. Holcomb, Hastelloy N for molten salt reactors used for power generation, ASME 2014 Symposium on Elevated Temperature Applications of Materials, ETAM 2014-1036, Seattle, March 25-27, 2014.

[78] W. Ren, Considerations of Hastelloy N Code Extension for Commercial Molten Salt Reactor Development and Deployment, in Proceedings of the ASME 2018 Pressure Vessel and Piping Division Conference, Prague, Czech Republic, July 15-20, 2018.

[79] R. N. Wright and T.-L. Sham, Status of Metallic Structural Materials for Molten Salt Reactors, INL/EXT-18-45171, Idaho National Laboratory, May 2018. 



\section{MATERIAL COMPATIBILITY}

\subsection{Introduction}

Among the many challenges presented by the use of molten halide salts is the corrosion of saltfacing structural components $[1,2]$. Experiments with molten salt corrosion date back to the Aircraft Reactor Experiment, which began in the 1940s at ORNL [3,4], and molten salt experiments continue today. Experimental efforts include work with fluoride and chloride salts in a range of conditions relevant to nuclear power system.

\subsection{Overview}

Most engineering materials rely on the formation of a passive oxide film for corrosion protection. In molten halide salts, however, these protective films do not form, because oxygen is not present except in small impurity concentrations. Therefore, corrosion of materials is dependent largely on interfacial reactions between the molten salt and the bare metal surface.

Alloy constituents tend to dissolve from the alloy into the salt in reverse order of their nobility, with the most active elements the most likely to dissolve. Experiments by DeVan and Evans [5] found that the dissolution of elements in molten fluorides also corresponds well with the stability of their metallic fluorides, as shown in Table 17. Alloy constituents with the most negative (most stable) halides tended to be the most likely to dissolve. Table 17 shows the free energy of formation for several fluoride and chloride compounds.

Table 17 Formation energies of fluoride and chloride compounds of some common alloy and salt constituents . Reproduced from ref. [6] with data from refs. [7,8]

\begin{tabular}{|ccc|}
\hline Cation species & \multicolumn{2}{c|}{$\begin{array}{c}\text { Free energy of formation at 1000 K } \\
\text { (kcal/mol-halide-element) } \\
\text { Chloride }\end{array}$} \\
\hline Salt Constituents & Fluoride & -124 \\
\hline Mg2+ & - & -84.0 \\
Li+ & -125 & -81.6 \\
Na+ & -112 & -87.4 \\
K+ & -109 & - \\
Zr4+ & -96.9 & \\
Alloy Constituents & & -71.4 \\
Cr2+ & -75.2 & -58.2 \\
Fe2+ & -66.4 & -49.9 \\
Ni2+ & -55.3 & \\
\hline
\end{tabular}


For most common structural alloys, $\mathrm{Cr}$ is the most active major constituent; and selective depletion of $\mathrm{Cr}$ from the alloy into the salt is the dominant form of material degradation in molten halides [1,2]. Therefore, control of $\mathrm{Cr}$ dissolution is central to corrosion mitigation in molten salts. For this reason, low-Cr alloys such as Hastelloy $\mathrm{N}$ are commonly used as salt-facing structural components. The relative stability of $\mathrm{Ni}$ compared with Fe explains the popularity of Ni-based alloys for use as structural materials in molten salts.

Beyond $\mathrm{Cr}$, other less-noble alloy additions such as silicon and aluminum have halides with low free energies of formation and thus have a tendency to dealloy in molten salts. Molybdenum, a major constituent of Hastelloy $\mathrm{N}$, is relatively stable in molten salts because of the high formation energy of its halides [5].

Results of corrosion experiments in molten fluoride and chloride salts compiled by Raiman and Lee [9] are shown in Figure 26. Corrosion rates are highly inconsistent because of the variety of conditions, methods, and salt chemistries used. Hastelloy $\mathrm{N}$ performs well in comparison with other materials, although some bias exists, as Hastelloy $\mathrm{N}$ was the material of choice for several early experiments conducted by ORNL for the MSRE and molten salt breeder reactor [10-12].

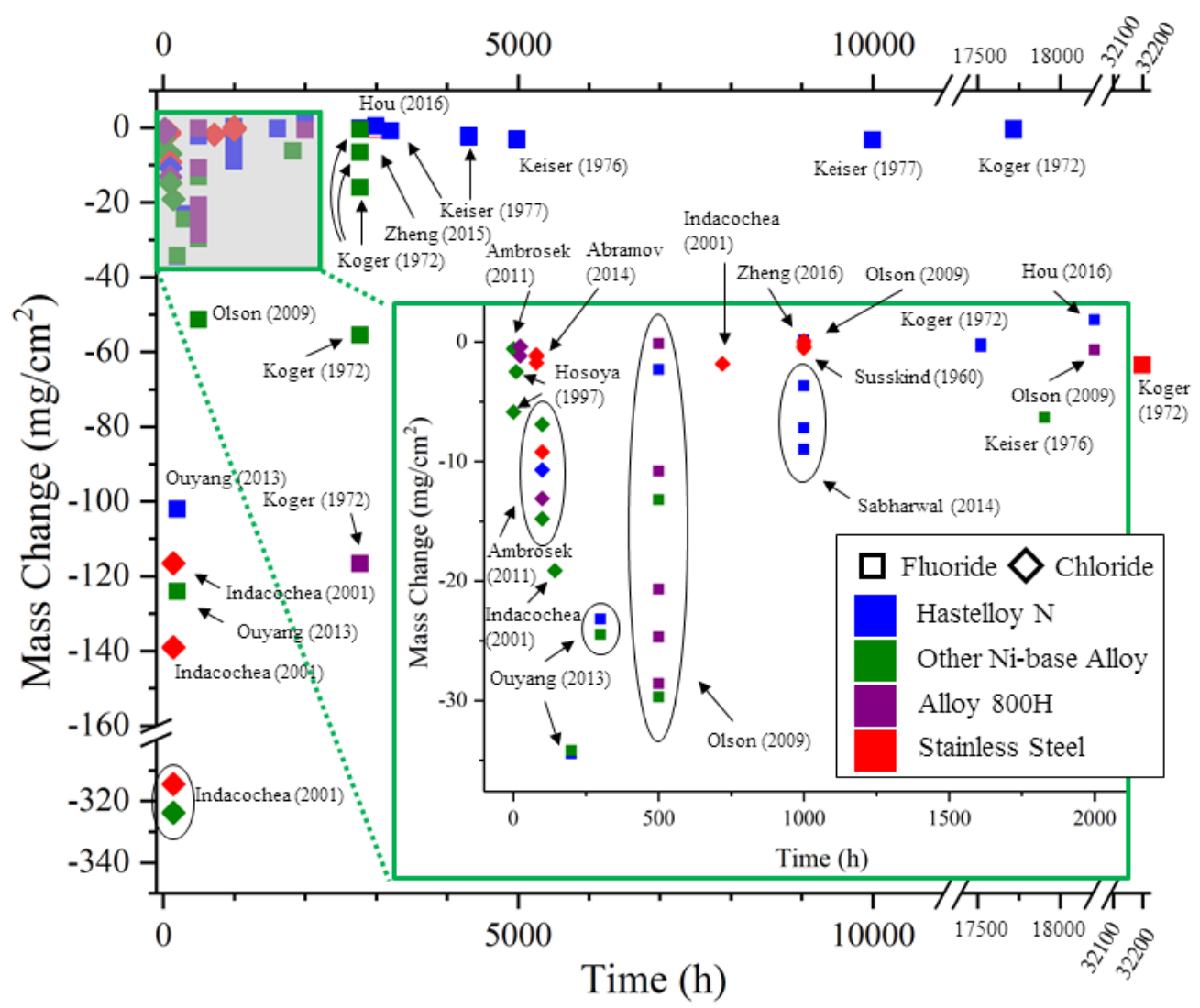

Figure 26 Mass change data as a function of time for corrosion experiments conducted in fluori de and chloride salts. Experiments are color coded by sample material. Reproduced from Ref. [9]. 


\subsection{Corrosion Testing}

Before presenting the results of corrosion studies in molten salts, it is worth discussing the main experimental techniques used in these studies. Corrosion testing in molten salts can be grouped into three categories-static tests, thermal loops, and pumped loops.

Static testing in molten salts is widely employed [13-16]. Static tests can be conducted in an open crucible with a (usually inert) cover gas, or in a sealed capsule. Unless a thermal gradient is imposed on flowing salt, the specimen and the salt will approach equilibrium, so static tests are less predictive than loop experiments. However, capsule and crucible experiments are a useful and economical way to conduct initial screening experiments, compare alloys, and conduct targeted corrosion studies to investigate specific phenomena in salt and alloys.

\subsubsection{Crucible tests}

One common approach is to expose samples in an open crucible containing molten salt, under an inert atmosphere cover gas. Unfortunately, tests in open capsules, even in highly pure atmospheres, are susceptible to impurity-driven corrosion. Crucible testing is useful for experiments that use in situ diagnostics such as electrochemistry [15,17-19]. Gomez-Vidal et al. used an open crucible with nitrogen as a cover gas to conduct electrochemical experiments in a $\mathrm{KCl}-\mathrm{LiCl}$ melt [15]. Platinum reference and counter electrodes were used to measure polarization plots for various alloys. The researchers recorded relatively high corrosion rates, in excess of a few $\mathrm{mm} /$ year for SSs and $\mathrm{Ni}$ alloys at $650^{\circ} \mathrm{C}$. The researchers did not attempt to purify the salts in their liquid state, so the polarization data likely reflected an initial period of very aggressive impurity-driven corrosion that could be expected to slow with exposure time as impurities are "consumed." Later work by Gomez-Vidal et al., using similarly unpurified chloride salt, recorded

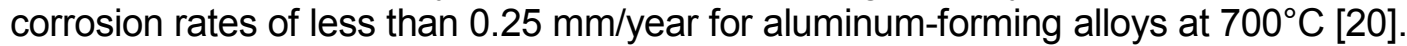
Electrochemical measurements were also performed by Vignarooban et al. [18][19].

\subsubsection{Sealed capsule tests}

To eliminate the effect of impurities in the cover gas, corrosion tests can be conducted in sealed capsules, a method employed by the University of Wisconsin [14,16,21,22] and the Chinese Academy of Sciences [23-25]. Researchers at ORNL have used Mo capsules, owing to its inertness in molten fluoride salts. The design of the capsules is shown in Figure 27. Capsules are filled in an inert atmosphere to 2/3 capacity, pumped down to rough vacuum, and then welded shut. The Mo capsules are sealed within SS outer capsules to prevent atmospheric degradation and then heated in high-temperature box furnaces. At the end of the exposure, the capsules are flipped upside down to allow the salt to drip from the sample surface for analysis. 

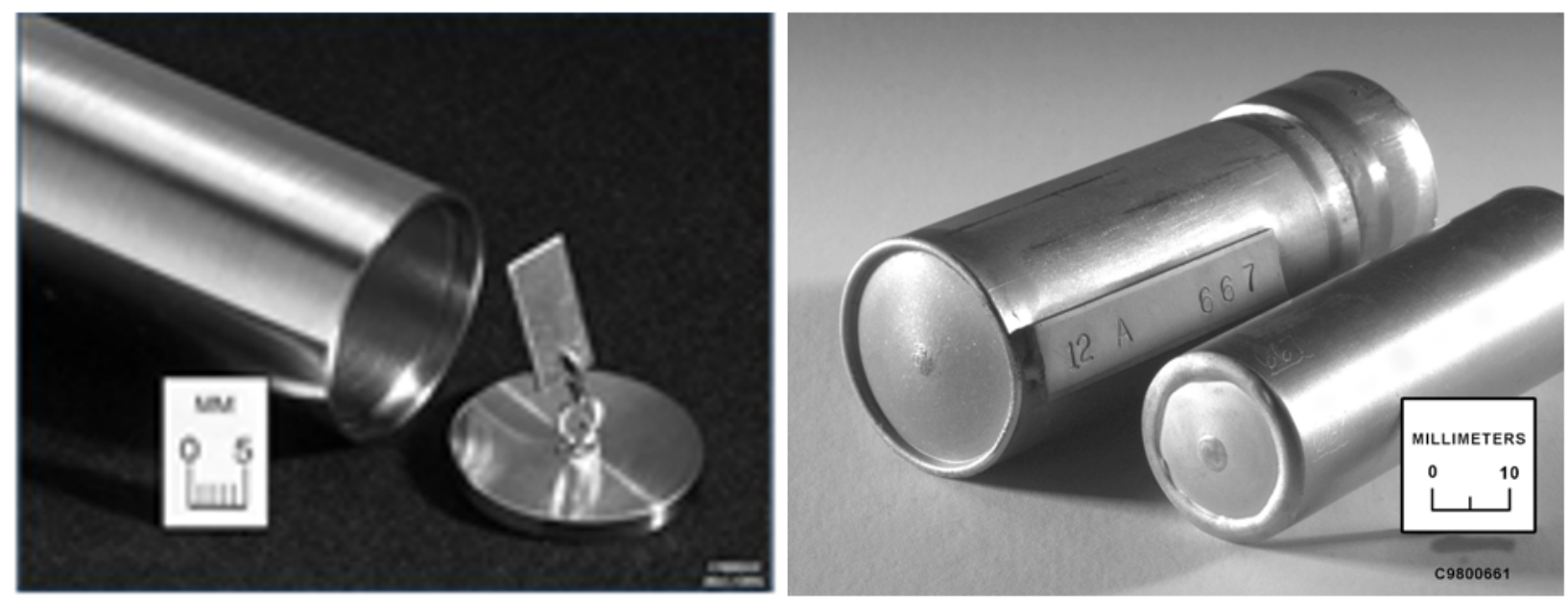

Figure 27 Capsule testing apparatus at ORNL. (L) A sample attached to the lid of the inner capsule and $(\mathrm{R})$ an inner capsule and outer capsule.

\subsubsection{Thermal convection loop testing}

Thermal convection loops add additional realism to molten salt corrosion testing. Extensive work was done at ORNL in the 1960s and 1970s using thermal convection loops to study corrosion of various structural materials in fluoride salts $[5,10,12,26,27]$. The loops employed a design (shown schematically in Figure 28) in which one side of the loop was heated and the other side was not. This served to both drive the flow of the loop and to more accurately recreate the conditions in a reactor. The work is well summarized by Koger [11], Ignatiev and Surenkov [28], and Sridharan and Allen [1]. The Oak Ridge researchers (as well as others [13,14,29]) reported that the primary mechanism of alloy degradation in molten fluoride salts is selective dissolution of $\mathrm{Cr}$ from the alloy into the salt. It was found during loop testing that samples in the hot side of the loop lost mass as a result of $\mathrm{Cr}$ dissolution, while samples in the cold side gained mass because of $\mathrm{Cr}$ deposition of from the hot side.

The thermal gradient in the loop experiments is important because the solubility of $\mathrm{Cr}$ is dependent on the temperature of the salt. This dependence creates a situation in which $\mathrm{Cr}$ tends to dissolve in the hot part of the loop where solubility is high, and precipitate in the cold part of the loop where solubility is lower.

Figure 29 shows corrosion of Inconel 600 in a thermal convection loop, in an experiment conducted by Manly at ORNL [30]. After an initial stage of impurity-driven degradation, corrosion slows to a steady state rate determined by the precipitation and dissolution of species due to the thermal gradient in the loop.

This steady state corrosion rate likely mimics the conditions in a reactor, as species are expected to dissolve in the reactor core. Thermal gradient loop experiments have also been conducted extensively by researchers at the Kurchatov Institute [28,31,32]. 


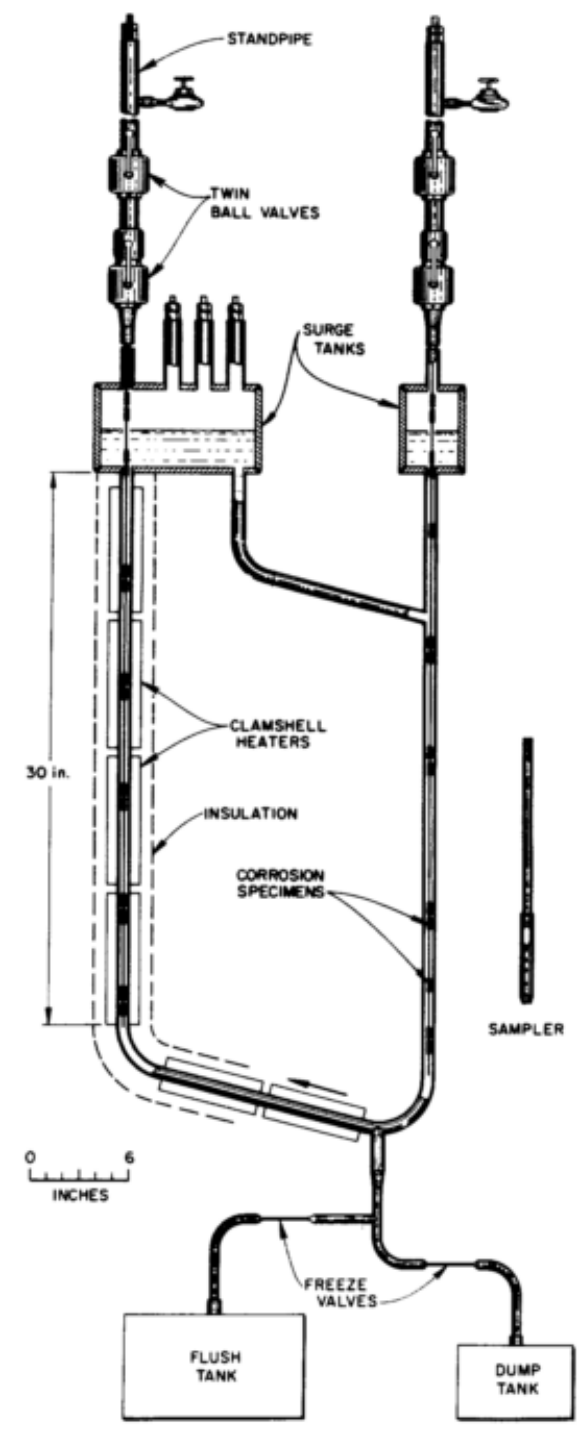

Figure 28 Schematic drawing of a thermal convection loop used for corrosion studies in molten fluoride at Oak Ridge National Laboratory. Reproduced from Ref. [10]. 


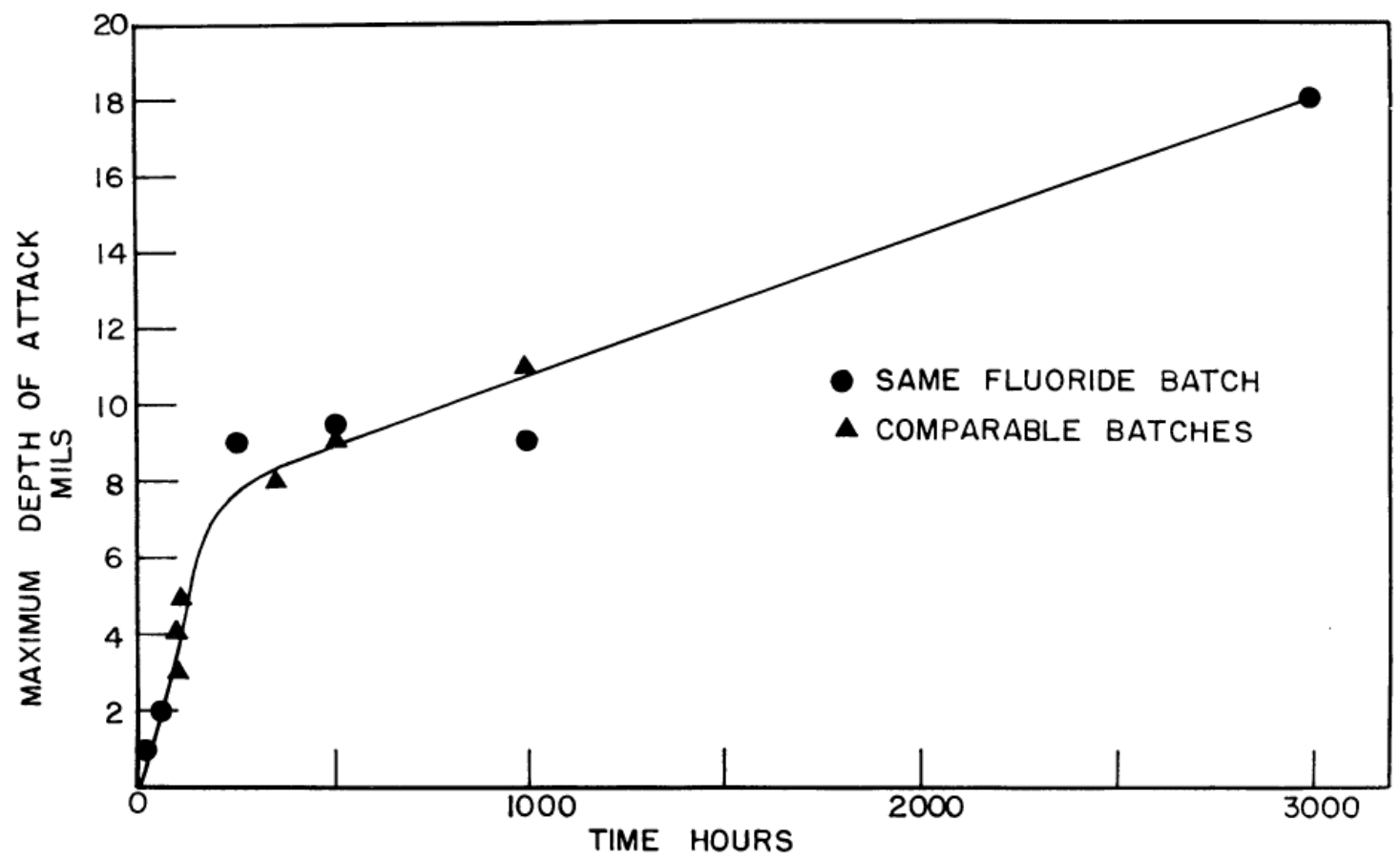

Figure 29 Corrosion of Inconel 600 in a thermal convection loop with uranium co ntaining FLiNaK salt at a temperature of $815^{\circ} \mathrm{C}$ in the hot leg. Reproduced from Ref. [30].

\subsubsection{Pumped loops}

Studies at Brookhaven National Laboratory [33] and ORNL [11,30] have examined corrosion in pumped loops, sometimes referred to as "forced convection loops." Because of the great expense involved with building and operating these loops, they are not a common choice for conducting corrosion experiments. However, corrosion testing can be conducted along with other experiments, such as thermal hydraulics, making the use of a pumped loop more economical for corrosion testing.

\subsection{Factors Affecting Corrosion}

\subsubsection{Impurity -driven corrosion}

Salt purification is crucially important in determining corrosion rates of materials in both fluoride and chloride salts. Experiments at ORNL by Keiser [26,34] and Koger [11,35] used effective saltpurification techniques. These experiments were run for more than $3000 \mathrm{~h}$ and exhibited very low corrosion rates, despite the use of more aggressive fuel salts. Despite the observed importance, salt purification is rarely quantified, and systematic studies of the effects of salt impurities are lacking.

Ouyang et al. [36] studied the effect of moisture on corrosion of Ni-base alloys in FLiNaK salt. The researchers exposed the samples in an autoclave with FLiNaK salt and a flowing argon cover gas with varying amounts of moisture. The results are reproduced in Figure 30. 


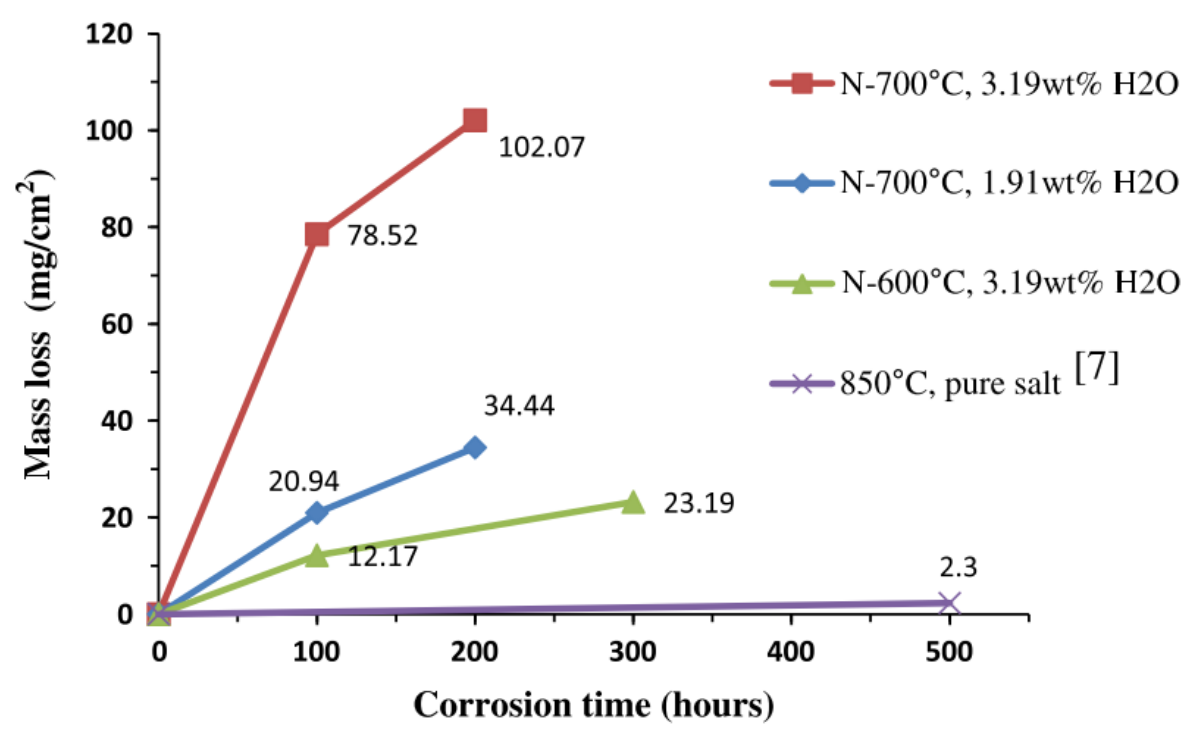

Figure 30 Mass loss of coupons exposed to FLiNaK salt with vari ous impurity contents. Reproduced from Ref. [36].

The Hastelloy $\mathrm{N}$ sample exposed to salt with $3.19 \% \mathrm{H}_{2} \mathrm{O}$ corroded nearly 3 times as fast as the sample exposed to $1.91 \% \mathrm{H}_{2} \mathrm{O}$, and nearly 50 times as fast as a sample exposed by Olson et al. [14] to pure salt at temperatures of $150^{\circ} \mathrm{C}$ or higher. This work clearly demonstrates the sizeable effect that added moisture has on corrosion.

Several studies have intentionally compared the effects of salt impurities. Indacochea et al. studied corrosion of Fe-based and Ni-based alloys in $\mathrm{Cl}$ salts. The salt used in a 1998 work by Indacochea et al. [37] was sparged with pure argon, and the salt used for a 2001 work, also by Indacochea et al., was bubbled with an argon-oxygen mixture [38]. Indacochea et al. reported that the first batch of samples in the oxygenated salt, which was exposed at the same time and temperature as the samples in purified salt $\left(720 \mathrm{~h}, 725^{\circ} \mathrm{C}\right)$, dissolved completely. A second batch was exposed at $650^{\circ} \mathrm{C}$ for $144 \mathrm{~h}$ and still recorded a much higher mass loss than the samples exposed in purified salt [38].

Olson et al. [14] compared samples of alloy $800 \mathrm{H}$ exposed in graphite capsules containing purified and unpurified salt. Contrary to other results, they found a higher corrosion rate with the purified salt than with the unpurified. This may be due to experimental variance, as corrosion rates for all samples that Olson exposed in graphite capsules were high, except the Hastelloy $\mathrm{N}$ sample. The effect of container material is discussed in greater detail below.

Ambrosek [16] conducted 24-h exposures in $\mathrm{KCl}-\mathrm{MgCl}_{2}$ with different purification treatments and found samples exposed in salts treated with solid magnesium or sparged with $\mathrm{CCl}_{4}$ lost less mass than samples in salt sparged with $\mathrm{HCl}$ or pure argon. It was determined that magnesium treatment was the superior method because of the toxicity of $\mathrm{CCl}_{4}$.

Hosoya et al. [39] exposed two samples for 70 minutes, one in salt that was dried in the solid state (but still not purified as a liquid) and one that was intentionally hydrated. The samples in the hydrated salt corroded $\sim 10$ times faster than the sample in dried salt. 
To remove impurities present in the as-received salts, many experiments used a process involving bubbling gas through the salts in their liquid state to remove moisture and metallic halides. ORNL researchers used $\mathrm{HF}-\mathrm{H}_{2}$ to remove oxides, sulfides, and metallic impurities from fluoride salts and found the process to be very effective $[40,41]$. This process was later used by researchers at Wisconsin $[14,42,43]$, and the Chinese Academy of Sciences [23,25].

Other researchers conducted experiments in unpurified fluoride salts [29, 44].

Fewer studies have examined purification of chloride salts. Researchers at Brookhaven National Laboratory and Argonne National Laboratory purified $\mathrm{KCl}-\mathrm{NaCl}-\mathrm{MgCl}_{2}$ salt by contacting it with bismuth containing $0.5 \% \mathrm{Mg}, 0.5 \% \mathrm{U}$, and $0.025 \% \mathrm{Zr}$ before use [33,45,46]. Ambrosek and researchers at Wisconsin [16] compared $\mathrm{KCl}-\mathrm{MgCl}_{2}$ salt purified with $\mathrm{Ar}, \mathrm{Ar}+\mathrm{HCl}$ gas, $\mathrm{Ar}+\mathrm{CCl}_{4}$ gas, and $\mathrm{Ar}+$ solid $\mathrm{Mg}$ and found the salts treated with $\mathrm{CCl}_{4}$ and $\mathrm{Mg}$ produced the best results. They concluded that magnesium was preferable because of the hazards associated with handling $\mathrm{CCl}_{4}$.

Several studies have also examined corrosion of materials in chloride salts that were not purified in their liquid state $[15,18,20,47,39]$. Most of these studies used a process in which solid salts were exposed to a purifying gas while being heated to a sub-melting temperature. The generally higher corrosion rates found by these studies suggest that dry gas sparging is insufficient as a purification method.

\subsubsection{Actinide corrosion}

Since most proposed MSR designs use a fuel-containing salt, it is important to understand how actinides affect the corrosion of salt-facing materials.

The corrosivity of the salt is largely driven by the ratio $U^{4+} / U^{3+}[5,48-50]$.

The reduction of uranium tetrafluoride to form uranium trifluoride can drive the oxidation of alloying element $\mathrm{Cr}$ to form $\mathrm{Cr}$ fluoride, according to the following reaction [5]:

$$
\mathrm{Cr}+2 U F_{4} \leftrightarrow \mathrm{CrF}_{2}+2 U F_{3} .
$$

To mitigate this reaction, a $U^{4+} / U^{3+}$ ratio of $10-100$ is typically maintained, which keeps the REDOX potential sufficiently low while minimizing the amount of $\mathrm{UF}_{3}$ in the salt. Keiser et al. [48] have reported that adding beryllium metal significantly lowers the $U^{4+} / U^{3+}$ ratio, thus reducing the REDOX potential of the salt [51].

Koger reported the percentage of $\mathrm{U}^{3+}$ in a thermal convection loop as a function of time; the results are shown in Figure 31. 


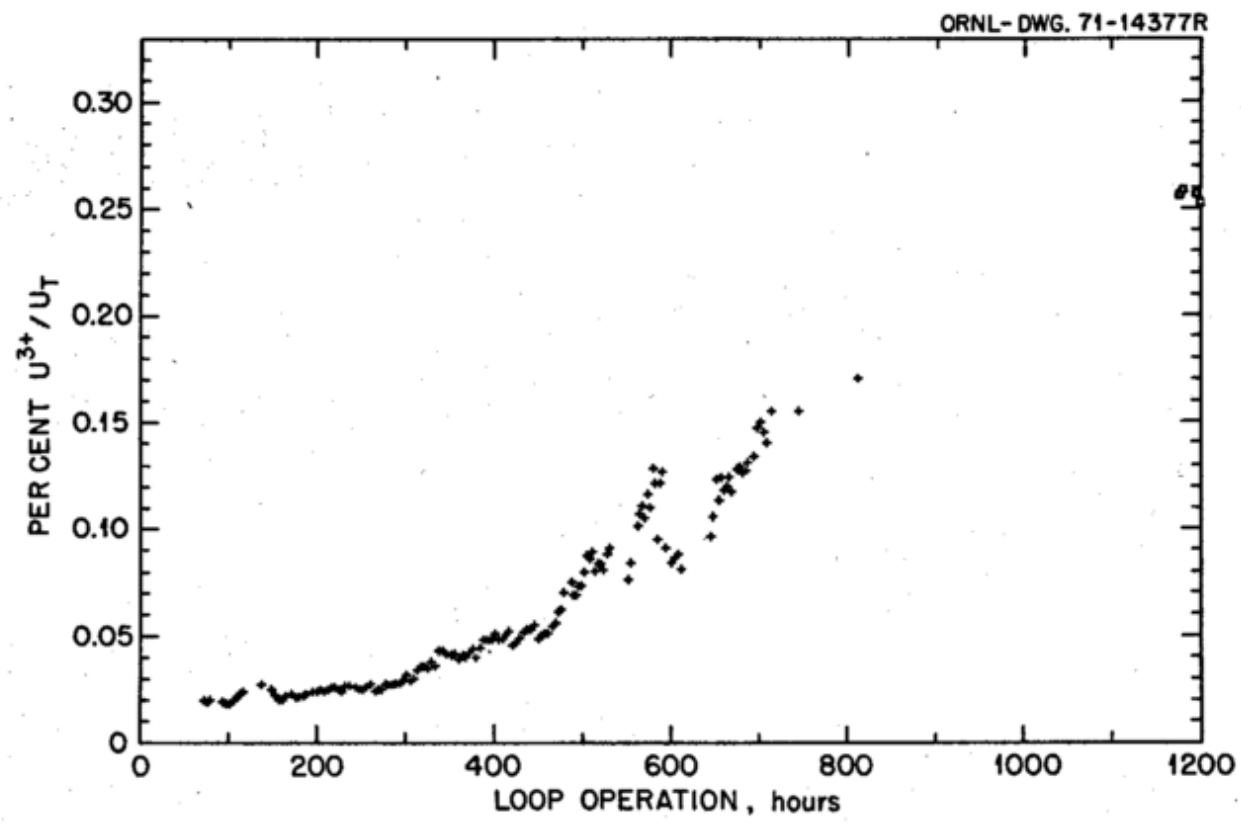

Figure 31 Uranium (III) as a function of total uranium in a thermal convection loop containing $\mathrm{LiF}-\mathrm{BeF}_{2}-\mathrm{ZrF}_{4}-\mathrm{UF}_{4}$ salt. Reproduced from Ref. [11].

\subsubsection{Fission product corrosion}

It is well known that fission products can affect corrosion of salt-facing materials. Work by ORNL researchers in the 1970s [48,52] and more recently at the Kurchatov Institute in Russia [32] explored the effect of Te on corrosion and embrittlement of Hastelloy N. The ORNL researchers found that beryllium metal additions were effective in reducing redox potential in fuel-containing salts with added Te.

Work by Koger [35] and Keiser [48] showed that controlling redox potential by adding beryllium effectively controlled Te-induced cracking, as shown in Figure 32. Small additions of Nb have also been shown to reduce cracking in salt-facing Hastelloy $N$ [27].

Another fission product of concern is tritium [1], a fission product that forms in lithium-based coolant salts. Aside from the radiological concerns posed by tritium, tritium-fluoride (TF) may form in the coolant and is corrosive to container materials. 
ORNL-DWG 77-4680

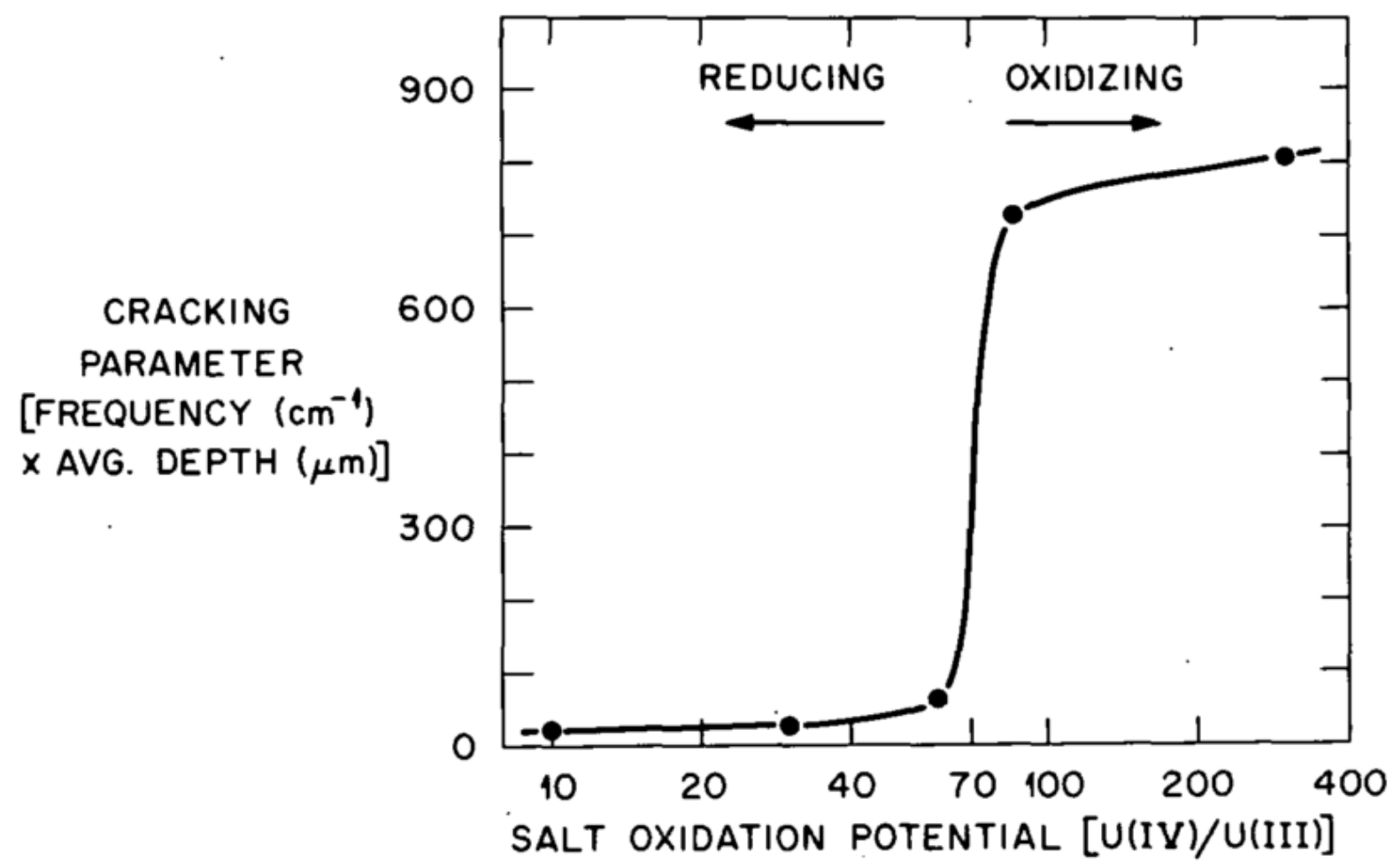

Figure 32 Cracking behavior of Hastelloy $\mathrm{N}$ exposed for $260 \mathrm{~h}$ at $700^{\circ} \mathrm{C}$ to molten salt breeder reactor fuel salt containing CrTe. Reproduced from Ref. [48].

\subsubsection{Irradiation and corrosion}

Irradiation may affect corrosion through a few processes. Although radiolysis is a concern in LWRs, radiolysis of the salt is not thought to be a concern under normal operating conditions [53]. Grimes reported that radiolysis is not a concern above $80^{\circ} \mathrm{C}[54]$.

Radiation is known to enhance diffusion kinetics [55]; and since solid state diffusion of $\mathrm{Cr}$ is an important part of the corrosion mechanism [50], it is a strong possibility that irradiation may accelerate corrosion by aiding transport of $\mathrm{Cr}$ to the alloy-salt interface. However this effect has not been directly studied.

Irradiation may also affect corrosion by altering the microstructure of the material. Zhu et al. [56] found a small increase in the $\mathrm{Cr}$ depletion rate of irradiated alloys with helium $(\mathrm{He})$ voids compared with unirradiated samples. Since $\mathrm{Cr}$ diffusion along grain boundaries is important to alloy corrosion, it is possible that irradiation-induced $\mathrm{Cr}$ depletion or the formation of grain boundary precipitates under irradiation may affect corrosion, but these effects have not been studied.

\subsection{Graphite Corrosion}

Graphite is the most commonly proposed moderator material for thermal reactors and is generally understood to have good compatibility with fluoride salts, exhibiting minimal mass loss. [57] However, fluorination is a concern because it can lead to chemical changes in the graphite [58]. 
Tang et al. [58] exposed several grades of graphite to molten FLiBe and observed that graphite grades with higher porosity experienced greater fluorine penetration than grades with lower porosity. This is especially concerning for fuel salts, as infiltration of fissile isotopes may affect core neutronics. Distefano et al. [27] asserted that graphite with pore sizes of $<1 \mu \mathrm{m}$ should resist salt intrusion; however, the research that led to this conclusion is not well documented.

Accordingly, more data are needed on effects of graphite in fluoride salts. Chloride salt data are not needed at this time, as chloride reactors are generally fast spectrum reactors that do not require moderation.

\subsection{Gaps in Understanding}

Currently, there are several gaps in the understanding of molten salt corrosion.

\subsubsection{Salt purity}

There are currently no standards for salt purity for conducting experiments in molten salt. Most available studies report the purification routines used for their salt, but they do not commonly report any analysis of the metal or oxide content of the salt after purification. Thus, there is no strong metric of the quality or effectiveness of the salt purification and no indication of the redox potential of the salt. This lack of standardization has led to extreme variability in data across studies. Because of this variability, is it difficult to compare results to obtain data on the corrosion properties of alloys, container materials, salt types, and so on.

Further, recent studies have been unable to replicate the very low corrosion rates reported by the Oak Ridge experiments in the 1960s and 1970s [10,11,26,27,34,35]. While a number of factors may contribute to this, a likely contributing factor is the lack of effective salt purification. The Oak Ridge experimenters used highly pure salts, but they released little data on purification techniques. The lack of knowledge transfer has resulted in a current generation of molten salt experimenters using more aggressive salts for corrosion testing, and reported corrosion rates in the last several decades have yet to consistently match the low corrosion rates reported by the early Oak Ridge experimenters.

It is therefore recommended that a greater emphasis be placed on the purification of molten salts for use in reactors and for experimentation. Further, standards for salt purity need to be developed so data can be compared across studies. Two suggested metrics for salt purity are maximum oxygen content and maximum metallic impurity content.

\subsubsection{Fission product corrosion}

The effect of fission products on corrosion is another area that is not well understood. Although past work has studied the effect of Te-family elements induced cracking [32,48], a significant knowledge gap exists regarding the effects of other fission products that may affect corrosion, among other materials issues. Among them, tritium is believed to be a potential corrodent, as it readily forms an oxidizing halide.

\subsubsection{Chloride salts}

Since fluoride salts were used in the MSRE and Aircraft Reactor Experiment, and have many favorable properties, they have been the subject of most of the research done on molten salts for nuclear applications. Chloride salts have received less research attention. With several vendors pursuing chloride-salt-based fast reactors, there is a need for more data on corrosion in chloride 
salts. In particular, purification techniques used with chloride salts have been considerably less effective than techniques used with fluoride salts [16]. This issue must be resolved if chloride salts are to be useful as MSR fuels or coolants.

\subsubsection{Irradiation -accelerated corrosion}

There presently are few data on the effects of radiation on corrosion. There are gaps in the current understanding of the effect of irradiation on salt properties, and of how irradiating salt might affect its corrosive properties. Further, understanding of the effect of radiation on saltmaterial interfaces is incomplete for both structural alloys and moderator materials. These knowledge gaps can be addressed with in-pile molten salt experimentation.

\subsection{Recommendations for Confirmatory Research}

\subsubsection{Systematic experimental data}

There is a serious shortage of quality data on corrosion of materials in molten salts. To enable understanding and quantification of materials degradation in molten salt environments, data need to be collected in a systematic fashion, using proper experimental controls. Data are also needed for purified salts that have been verified using high-quality analytic chemistry before exposure. Experimental data are especially needed for salts with different impurity levels to understand the realistic limits that must be met for salt purification to enable acceptable material performance.

\subsubsection{Greater thermodynamic data}

There is also a need for more thermodynamic data to enable better prediction of material behavior in molten salts. Although some thermodynamic models exist, databases are incomplete, especially for chloride salts. A concerted development effort combining calculation of phase diagrams (CALPHAD) modeling [59] with targeted experimentation to measure fundamental parameters is recommended to address this deficiency.

\subsubsection{Modeling}

Since corrosion will be an important lifetime-limiting degradation mode for structural materials, predictive models are needed to aid in reactor design and licensing. Although physics-based models are desired, empirically based rate models are an important step and should aid in the design and licensing of MSRs.

\subsection{References}

[1] K. Sridharan and T.R.R. Allen, Corrosion in Molten Salts, Elsevier Inc., 2013. doi:10.1016/B978-0-12-398538-5.00012-3.

[2] V. Ignatiev and A. Surenkov, Corrosion phenomena induced by molten salts in Generation IV nuclear reactors, chapter 5 in: Struct. Mater. Gener. IV Nucl. React., 2017: pp. 153-189. doi:10.1016/B978-0-08-100906-2.00005-7.

[3] E.S. Bettis, W.B. Cottrell, E.R. Mann, J.L. Meem, and G.D. Whitman, The Aircraft Reactor Experiment-Operation 1, Nucl. Sci. Eng. 2, 841-853, 1957.

http://moltensalt.org/references/static/downloads/pdf/NSE_ARE_Operation.pdf. 
[4] W.D. Manly, G.M. Adamson, J.H. Coobs, J.H. DeVan, D.A. Douglas, E.E. Hoffman, P. Patriarca, Aircraft Reactor Experiment-Metallurgical Aspects, ORNL-2349, Oak Ridge National Laboratory, 1957, p. 59.

[5] J.H. DeVan and R.B. Evans, Corrosion Behavior of Reactor Materials in Fluoride Salt Mixtures, ORNL-TM-0328, Oak Ridge National Laboratory, 1962, pp. 1-39. doi:ORNLTM-0328.

[6] D.F. Williams, Assessment of Candidate Molten Salt Coolants for the NGNP/NHI HeatTransfer Loop, ORNL/TM-2006/69, 2006. http://www.ntis.gov/support/ordernowabout.htm (accessed December 2, 2016).

[7] C.F. Baes, The chemistry and thermodynamics of molten salt reactor fuels, J. Nucl. Mater. 5, 1974. http://orproxy.lib.utk.edu:2101/002231157490124X/1-s2.0002231157490124X-main.pdf?_tid=c7b86332-8e68-11e7-9df600000aab0f01\&acdnat=1504196813_aee8f7f0acb4ddc9383b75aa21cd0d4e (accessed August 31, 2017).

[8] J.A. Plambeck, Electromotive Force Series in Molten Salts, (n.d.). http://pubs.acs.org/doi/pdf/10.1021/je60032a023 (accessed October 9, 2017).

[9] S.S. Raiman and S. Lee, Aggregation and data analysis of corrosion studies in molten chloride and fluoride salts, J. Nucl. Mater. 511, 523-535, rev., 2018.

[10] J.R. Keiser, Compatability Studies of Potential Molten Salt Breeder Reactor Materials in Molten Fluoride Salts, ORNL/TM/5783, Oak Ridge National Laboratory, 1977.

[11] J.W. Koger, Evaluation of Hastelloy N Alloy after Nine Years Exposure to both a Molten Fluoride Salt and Air at Temperatures from 700 to $560^{\circ} \mathrm{C}$, ORNL-TM-4189, Oak Ridge National Laboratory, 1972. http://moltensalt.org/references/static/downloads/pdf/ORNLTM-4189.pdf.

[12] J.R. Keiser, D.L. Manning, and R.E. Clausing, Corrosion resistance of some nickel-base alloys to molten fluoride salts containing UF4 and tellurium, in: Molten Salts, The Electrochemical Society, New York, 1976, pp. 315-328.

[13] G. Zheng, L. He, D. Carpenter, and K. Sridharan, Corrosion-induced microstructural developments in 316 stainless steel during exposure to molten Li2BeF4(FLiBe) salt, J. Nucl. Mater. 482, 147-155, 2016. doi:10.1016/j.jnucmat.2016.10.023.

[14] L.C. Olson, J.W. Ambrosek, K. Sridharan, M.H. Anderson, and T.R. Allen, Materials corrosion in molten LiF-NaF-KF salt, J. Fluor. Chem. 130, 67-73, 2009. doi:10.1016/j.jfluchem.2008.05.008.

[15] J.C. Gomez-Vidal and R. Tirawat, Corrosion of alloys in a chloride molten salt ( $\mathrm{NaCl}-\mathrm{LiCl})$ for solar thermal technologies, Sol. Energy Mater. Sol. Cells. 157, 234-244, 2016. doi:10.1016/j.solmat.2016.05.052.

[16] J. Ambrosek, Molten Chloride Salts for Heat Transfer in Nuclear Systems, University of Wisconsin, 2011.

[17] X.K. Feng, C.A. Melendres, Anodic corrosion and passivation behavior of some metals in molten LiCl-KCl containing oxide ions, J. Electrochem. Soc. 129, 1982. http://jes.ecsdl.org/content/129/6/1245.full.pdf (accessed September 5, 2017).

[18] K. Vignarooban, P. Pugazhendhi, C. Tucker, D. Gervasio, and A.M. Kannan, Corrosion resistance of Hastelloys in molten metal-chloride heat-transfer fluids for concentrating 
solar power applications, Sol. Energy. 103, 62-69, 2014.

doi:10.1016/j.solener.2014.02.002.

[19] K. Vignarooban, X. Xu, K. Wang, E.E. Molina, P. Li, D. Gervasio, and A.M. Kannan, Vapor pressure and corrosivity of ternary metal-chloride molten-salt based heat transfer fluids for use in concentrating solar power systems, Appl. Energy. 159, 206-213, 2015. doi:10.1016/j.apenergy.2015.08.131.

[20] J.C.C. Gomez-Vidal, A.G.G. Fernandez, R. Tirawat, C. Turchi, and W. Huddleston, Corrosion resistance of alumina-forming alloys against molten chlorides for energy production. I: Pre-oxidation treatment and isothermal corrosion tests, Sol. Energy Mater. Sol. Cells. 166, 222-233, 2017. doi:10.1016/j.solmat.2017.02.019.

[21] P. Sabharwall, M. Ebner, M. Sohal, P. Sharpe, M. Anderson, K. Sridharan, J. Ambrosek, L. Olson, and P. Brooks, Molten Salts for High Temperature Reactors: University of Wisconsin Molten Salt Corrosion and Flow Loop Experiments - Issues Identified and Path Forward, INL/EXT-10-18090, Idaho National Laboratory, 2010. https://inldigitallibrary.inl.gov/sites/sti/sti/4502649.pdf (accessed September 17, 2017).

[22] W.-J. Cheng, R.S. Sellers, M.H. Anderson, K. Sridharan, C.-J. Wang, and T.R. Allen, Zirconium effect on the corrosion behavior of 316I stainless steel alloy and Hastelloy-N superalloy in molten fluoride salt, Nucl. Technol. 183, 248-259, 2017. http://www.tandfonline.com/doi/pdf/10.13182/NT12-125?needAccess=true (accessed September 19, 2017).

[23] J. Hou, G. Yu, C. Zeng, H. Ai, R. Xie, Y. Chen, X. Zhou, L. Xie, and J. Wang, Effects of exposing duration on corrosion performance in weld joint of Ni-Mo-Cr alloy in FLiNaK molten salt, J. Fluor. Chem. 191, 110-119, 2016. doi:10.1016/j.jfluchem.2016.07.007.

[24] X. Yang, D. Zhang, M. Liu, S. Feng, W. Xue, H. Liu, G. Yu, X. Zhou, H. Xia, P. Huai, Z. Li, Y. Lu, H. Zhou, and S. Dong, Corrosion of SiC induced by Hastelloy $\mathrm{N}$ alloy and its corrosion products in LiF-NaF-KF molten salt, Corros. Sci. 109, 62-67, 2016. doi:10.1016/j.corsci.2016.03.029.

[25] J. Qiu, Y. Zou, G. Yu, H. Liu, Y. Jia, Z. Li, P. Huai, X. Zhou, and H. Xu, Compatibility of container materials with $\mathrm{Cr}$ in molten FLiNaK salt, J. Fluor. Chem. 168, 69-74, 2014. doi:10.1016/j.jfluchem.2014.09.010.

[26] J.R. Keiser, J.H. DeVan, E.J. Lawrence, Compatibility of molten salts with type 316 stainless steel and lithium, J. Nucl. Mater. 85-86, Par (1979) 295-298. doi:10.1016/00223115(79)90505-1.

[27] J.R. Distefano, J.H. Devan, J.R. Keiser, R.L. Klueh, and W.P. Eatherly, Materials Considerations for Molten Salt Accelerator Based Plutonium Conversion Systems, ORNL/TM/12925/R1, Oak Ridge National Laboratory, 1995.

[28] V. Ignatiev and A. Surenkov, Alloys compatibility in molten salt fluorides: Kurchatov Institute related experience, J. Nucl. Mater. 441, 592-603, 2013. doi:10.1016/j.jnucmat.2013.05.007.

[29] M. Liu, J. Zheng, Y. Lu, Z. Li, Y. Zou, X. Yu, X. Zhou, Investigation on corrosion behavior of Ni-based alloys in molten fluoride salt using synchrotron radiation techniques, J. Nucl. Mater. 440, 124-128, 2013. doi:10.1016/j.jnucmat.2013.04.056.

[30] W.D. Manly, G.M. Adamson, J.H. Coobs, J.H. DeVan, D.A. Douglas, E.E. Hoffman, and P. Patriarca, Aircraft Reactor Experiment-Metallurgical Aspects, ORNL TM-2349, Oak Ridge National Laboratory, 1957. 
[31] V. Ignatiev, A. Surenkov, I. Gnidoi, V. Fedulov, V. Uglov, V. Afonichkin, A. Bovet, V. Subbotin, A. Panov, and A. Toropov, Compatibility of selected Ni-based alloys in molten $\mathrm{Li}, \mathrm{Na}, \mathrm{Be} / \mathrm{F}$ salts with $\mathrm{PuF}_{3}$ and tellurium additions, Nucl. Technol. 164, 130-142, 2008. doi:10.13182/NT08-A4014.

[32] V. Ignatiev, A. Surenkov, I. Gnidoy, A. Kulakov, V. Uglov, A. Vasiliev, and M. Presniakov, Intergranular tellurium cracking of nickel-based alloys in molten $\mathrm{Li}, \mathrm{Be}, \mathrm{Th}, \mathrm{U} / \mathrm{F}$ salt mixture, J. Nucl. Mater. 440, 243-249, 2013. doi:10.1016/j.jnucmat.2013.05.001.

[33] H. Susskind, F.B. Hill, L. Green, S. Kalish, L.E. Kukacka, W.E. McNulty, and E.J. Wirsing, Corrosion Studies for a Fused Salt-liquid Metal Extraction Process for the Liquid Metal Fuel Reactor, BNL-585, Brookhaven National Laboratory, Upton, NY, 1960. doi:10.2172/4023508.

[34] J.R. Keiser, Compatibility Studies of Potential Molten-salt Breeder Reactor Materials in Molten Fluoride Salts, ORNL/TM-5783, Oak Ridge National Laboratory, 1977. https://inis.iaea.org/search/search.aspx?orig_q=RN:8342890 (accessed April 30, 2017).

[35] J.W. Koger, Alloy Compatibility with LiF-BeF Salts Containing ThF and UF, ORNL/TM/4286, Oak Ridge National Laboratory, 1972.

[36] F.Y. Ouyang, C.H. Chang, B.C. You, T.K. Yeh, and J.J. Kai, Effect of moisture on corrosion of Ni-based alloys in molten alkali fluoride FLiNaK salt environments, J. Nucl. Mater. 437, 201-207, 2013. doi:10.1016/j.jnucmat.2013.02.021.

[37] J.E. Indacochea, J.L. Smith, K.R. Litko, and E.J. Karell, Corrosion performance of ferrous and refractory metals in molten salts under reducing conditions, Journal of Materials Research 14(5), 1990-1995, 1998. doi:10.1557/JMR.1999.0268.

[38] J.E. Indacochea, J.L. Smith, K.R. Litko, E.J. Karell, and A.G. Raraz, High-temperature oxidation and corrosion of structural materials in molten chlorides, Oxid. Met. 55(1-2), 116, 2001.

[39] Y. Hosoya, T. Terai, T. Yoneoka, and S. Tanaka, Compatibility of structural materials with molten chloride mixture at high temperature, J. Nucl. Mater. 248, 348-353, 1997.J.H. Shaffer, Preparation and Handling of Salt Mixtures for the Molten Salt Reactor Experiment, ORNL-4616, Oak Ridge National Laboratory, 1971, p. 45.

[40] R.C. Robertson, Conceptual Design Study of a Single-fluid Molten-salt Breeder Reactor, ORNL-4541, Oak Ridge National Laboratory, 1971.

[41] B.C. Kelleher, K.P. Dolan, P. Brooks, M.H. Anderson, and K. Sridharan, Batch-scale hydrofluorination of Li $27 \mathrm{BeF} 4$ to support molten salt reactor development, J. Nucl. Eng. Radiat. Sci. 1, 041010, 2015. doi:10.1115/1.4030963.

[42] G. Zheng, B. Kelleher, G. Cao, M. Anderson, T. Allen, and K. Sridharan, Corrosion of 316 stainless steel in high temperature molten Li2BeF4 (FLiBe) salt, J. Nucl. Mater. 461, 143150, 2015. doi:10.1016/j.jnucmat.2015.03.004.

[43] F.-Y. Ouyang, C.-H. Chang, and J.-J. Kai, Long-term corrosion behaviors of Hastelloy-N and Hastelloy-B3 in moisture-containing molten FLiNaK salt environments, J. Nucl. Mater. 446, 81-89, 2014. doi:10.1016/j.jnucmat.2013.11.045.

[44] C.J. Raseman, H. Susskind, G. Farber, W.E. McNulty, and F.J. Salzano, Engineering Experience at Brookhaven National Laboratory in Handling Fused Chloride Salts, BNL627; T-192, Brookhaven National Laboratory, 1960.

https://www.osti.gov/scitech/servlets/purl/4068644 (accessed July 19, 2017). 
[45] T.R. Johnson, F.G. Teats, and R.D. Pierce, A Method for the Purification of Molten Chloride Salts, ANL-7603, Argonne National Laboratory,1969.

[46] M. Hofmeister, L. Klein, H. Miran, R. Rettig, S. Virtanen, and R.F. Singer, Corrosion behaviour of stainless steels and a single crystal superalloy in a ternary $\mathrm{LiCl}-\mathrm{KCl}-\mathrm{CsCl}$ molten salt, Corros. Sci. 90, 46-53, 2015. doi:10.1016/j.corsci.2014.09.009.

[47] Y. Hosoya, T. Terai, T. Yoneoka, and S. Tanaka, Compatibility of structural materials with molten chloride mixture at high temperature, J. Nucl. Mater. 248, 348-353, 1997.

[48] J.R. Keiser, Status of Tellurium-Hastelloy N Studies in Molten Fluoride Salts, ORNL/TM6002, 1977.

[49] J.R.J. Weir, D.A. Douglas, and W.D. Manly, Inconel as a Structural Material for a HighTemperature Fused-Salt Reactor, ORNL-2264, 1957. doi:ORNL-2264.

[50] B.-W.D. Manly, J.W. Allen, W.H. Cook, J.H. DeVan, D.A. Douglas, H. Inouye, D.H. Jansen, P. Patriarea, T.K. Roche, G.M. Slaughter, A. Taboada, and G.A. Tolson, Construction Materials for Molten Salt Reactors, chapter 13 in: Molten Salt Reactor Construction Materials, n.d.

http://moltensalt.org/references/static/downloads/pdf/FFR_chap13.pdf (accessed July 13, 2017).

[51] D. Olander, Redox condition in molten fluoride salts: Definition and control, J. Nucl. Mater. 300 (2-3), 270-272, February 2002. https://doi.org/10.1016/S0022-

3115(01)00742-5 (accessed December 2018).

[52] H.E. McCoy, Status of Materials Development for Molten Salt Reactors, ORNL TM-5920, Oak Ridge National Laboratory, January 1978.

http://moltensalt.org/references/static/downloads/pdf/ORNL-TM-5920.pdf (accessed December 2018).

[53] Radiolysis of Salts and Long-Term Storage Issues for Both Pure and Impure PuO 2 Materials in Plutonium Storage Containers, LA-13725-MS, Los Alamos National Laboratory, May 2000.

http://www.iaea.org/inis/collection/NCLCollectionStore/_Public/32/016/32016719.pdf (accessed December 2018).

[54] W.R. Grimes, Chemical Research and Development for Molten-salt Breeder Reactors, ORNL-TM-1853, June 1967. http://moltensalt.org/references/static/downloads/pdf/ ORNL-TM-1853.pdf (accessed December 2018).

[55] R. Sizmann, The effect of radiation upon diffusion in metals, J. Nucl. Mater. 69-70, 386412, 1978. Doi: 10.1016/0022-3115(78)90256-8.

[56] H. Zhu, R. Holmes, T. Hanley, J. Davis, K. Short, L. Edwards, and Z. Li, Effects of bubbles on high-temperature corrosion of helium ion-irradiated Ni-based alloy in fluoride molten salt, Corros. Sci. 125, 184-193, 2017. doi:10.1016/j.corsci.2017.06.027.

[57] B.J. Sheil and R.B. Evans, Molten Salt-Graphite Compatibility Test. Results of Physical and Chemical Measurements, CF-59-8-133, Oak Ridge National Laboratory, 1959. https://www.osti.gov/servlets/purl/4098729 (accessed December 2018).

[58] H. Tang, W. Qi, Z. He, H. Xia, Q. Huang, C. Zhang, X. Wang, J. Song, P. Huai, and X. Zhou, Infiltration of graphite by molten 2LiF-BeF2 salt, Journal of Materials Science 52(6), (2017). doi:10.1007/s10853-017-1310-4.

[59] P.J. Spencer, A brief history of CALPHAD, Calphad 32(1), 1-8, 2008. 


\section{IRRADIATION}

Materials in MSRs are expected to operate at temperatures in the range of $\sim 500-800^{\circ} \mathrm{C}$ and experience lifetime doses of up to 100-150 dpa while also being exposed to molten salt [1]. They must retain adequate mechanical properties and dimensional stability while under these harsh conditions [1]. A structural material is suitable for MSRs if the operating temperature is up to $\sim 2 / 3$ of the material's melting point on the Kelvin scale [2]. For example, an alloy with a melting point of $900^{\circ} \mathrm{C}$ is not good for an MSR with an operational temperature of $>500^{\circ} \mathrm{C}$ [2]. For these hightemperature applications, often ceramics, graphite, and Ni-based alloys are the leading candidates.

Based on the work of the MSRE, which operated 1965-69, and the associated research which continued into the 1970s at ORNL, the core moderator materials must have good neutron moderation, low neutron absorption, compatibility with the molten salt and other materials, low permeability to salt and fission gases, the ability to be fabricated into the needed geometries, the ability to be joined to other materials in the system, and the ability maintain those properties through at least several years of neutron dose at elevated temperature $[3,14]$. Structural materials must resist salt corrosion, be compatible with and able to be joined to the core material, be fabricable into the needed geometries, maintain strength and ductility through their lifetimes at elevated temperatures, and withstand neutron irradiation for a minimum of several years and possibly the life of the reactor [3]. Some materials away from the core, such as piping, will have reduced neutron fluence exposure, so not all materials in the reactor need to have the same level of neutron damage resistance [3].

The basic interactions that neutrons have with materials that lead to damage are that they either ballistically move an atom off its lattice site or are absorbed into the atom and cause it to transmute. The ballistic damage creates point defects in the material that (combined with other factors such as temperature or stress) can lead to numerous negative macroscopic effects including hardening, embrittlement, swelling, precipitation, or phase changes. Transmutation can damage materials because either the daughter element is detrimental in the material or, if $\mathrm{He}$ is released in the reaction, the He can embrittle the material.

To determine if a material is suitable for an MSR, it needs to be systematically irradiated over a relevant range of temperatures and neutron doses, and multiple properties need to be measured. Properties of interest include thermal (thermal conductivity, thermal expansion), physical (swelling, thermal creep, irradiation creep), and mechanical (tensile, fracture toughness, hardness). To understand these properties, it is critical to have corresponding microstructural information (precipitate, void, bubble, grain sizes and characteristics) and elemental information (transmutation elements, He atomic parts per million (appm), segregation, precipitate composition, and phase).

In this section, the irradiation data for several classes of materials considered for MSRsincluding Hastelloy $\mathrm{N}$, other Ni-based alloys, graphite, and silicon carbide ( $\mathrm{SiC}$ )—have been collected. Stainless steels and refractory alloys are also potential candidates for MSR materials; but these materials generally have had significant neutron irradiation testing, and the results are not presented here. The data presented here have been evaluated to determine if the necessary thermal, physical, and mechanical property measurements are available and how much supporting microstructural and elemental information exists. Gaps in the necessary data have been identified and, where appropriate, the existing data have been critically evaluated. 
Recommendations are given for the additional work needed to prepare materials for use in an MSR.

\subsection{Hastelloy $\mathrm{N}$ and Modified Haste lloy $\mathrm{N}$}

\subsubsection{Summary of previous work}

The MSRE at ORNL used Hastelloy $\mathrm{N}$ as the structural material. Hastelloy $\mathrm{N}$ has the nominal composition of $\mathrm{Ni}$ (base), $16 \% \mathrm{Mo}, 7 \% \mathrm{Cr}, 5 \% \mathrm{Fe}, 0.5 \% \mathrm{Si}$, and $0.05 \% \mathrm{C}$ and is the trade name of the ORNL-created alloy INOR 8 [4]; it is also sometimes referred to as Alloy N. Hastelloy is solution-strengthened by the Mo [3]. Some $\mathrm{Cr}$ is needed to prevent oxidation of the air-facing sides of components; but Cr easily dissolves in fluoride salts, so the amount that can be added is limited [3]. Aluminum ( $\mathrm{Al}$ ), titanium (Ti), and carbon were found to have negative effects on fabrication and corrosion if present in more than small quantities in the alloy [3]. If too much Mo is in the alloy, coarser precipitates form, which are undesirable [3].

The precipitates in Hastelloy $\mathrm{N}$ were found to be critical to determining the mechanical properties before and after irradiation. To investigate the precipitates in Hastelloy $\mathrm{N}$, some ${ }^{14} \mathrm{C}$ was added to the usual composition of commercial Hastelloy $\mathrm{N}$ [5]. Sections of the material were given different heat treatments, then cross sectioned, polished, and spread with an Eastman NTB liquid emulsion, which is sensitive to the beta decay of the ${ }^{14} \mathrm{C}[5]$. Exposed autoradiographs (sensitive to the carbon location) and traditional microscopy images (able to reveal features such as grain boundaries and precipitates) were examined to determine the location of the carbon relative to other features [5]. In the as-fabricated state, the Hastelloy had so-called "stringers" of precipitates that were typically $2.5-25 \mu \mathrm{m}$ in diameter; and when it was annealed at above $1260^{\circ} \mathrm{C}$, a lamellar phase was observed [5]. By observing the microscope and autoradiograph images, McCoy et al. determined that both of these types of precipitates have less carbon than the matrix [5]. When Hastelloy $\mathrm{N}$ was annealed at above $1260^{\circ} \mathrm{C}$, a noticeable amount of carbon segregated to the grain boundaries [5]. These results led the authors to postulate that the stringer precipitates may be a modified delta phase between $\mathrm{Ni}$ and $\mathrm{Mo}$ and that the lamellar phase may be a transition from the delta phase to alpha and gamma [5].

The report was unable to identify more details about the precipitates, such as if they take the form $\mathrm{MC}$ or $\mathrm{M}_{6} \mathrm{C}$, which are much discussed in the other MSRE reports. Note that the images in that report were at 100,250 , or 750 times magnification, which is extraordinarily low compared with today's standards. While these are appropriate magnifications to observe several grains in one image, it is questionable how much information could be gathered about the precipitates they were observing at this low magnification. For example, Figure 3 from Ref. [5] (Figure 33) is one of the key images on which the authors based their observation that the precipitates were not enriched in carbon. However, the observable dark and light features in the image, which are the carbon-rich areas and precipitates, respectively, are each only a handful of pixels in size (Figure 33). Without some calculated statistics and a closer view, it is very difficult to make strong judgements on the relation of the carbon and the precipitates. From the image, there is no way to tell what phase/elemental composition the precipitates are.

Other images from the report, for example Figure 34, provide some information about carbon at the grain boundaries, but the quality of the image in part (a), is poor and only general qualitative information can be learned about the carbon behavior in the material. Additionally, some images throughout the MSRE project are of such poor quality that the subject of the image is difficult to identify. This is not limited to the 1966 report [5], but one example from that report is reproduced here in Figure $34 \mathrm{~b}$. The image has a stripe of light contrast with jagged edges at the center and 
very dark contrast areas below and above. From the descriptions in the report, it is unclear what the image is showing. It could be that the image shows part of a sample and part of a mounting structure, or in fact shows a large carbon-free region, or even that the original image was damaged in the photocopying or digital archiving process. The microscopy techniques of today would be more easily able to examine individual precipitates in Hastelloy $\mathrm{N}$ to determine their composition and relation to the matrix.

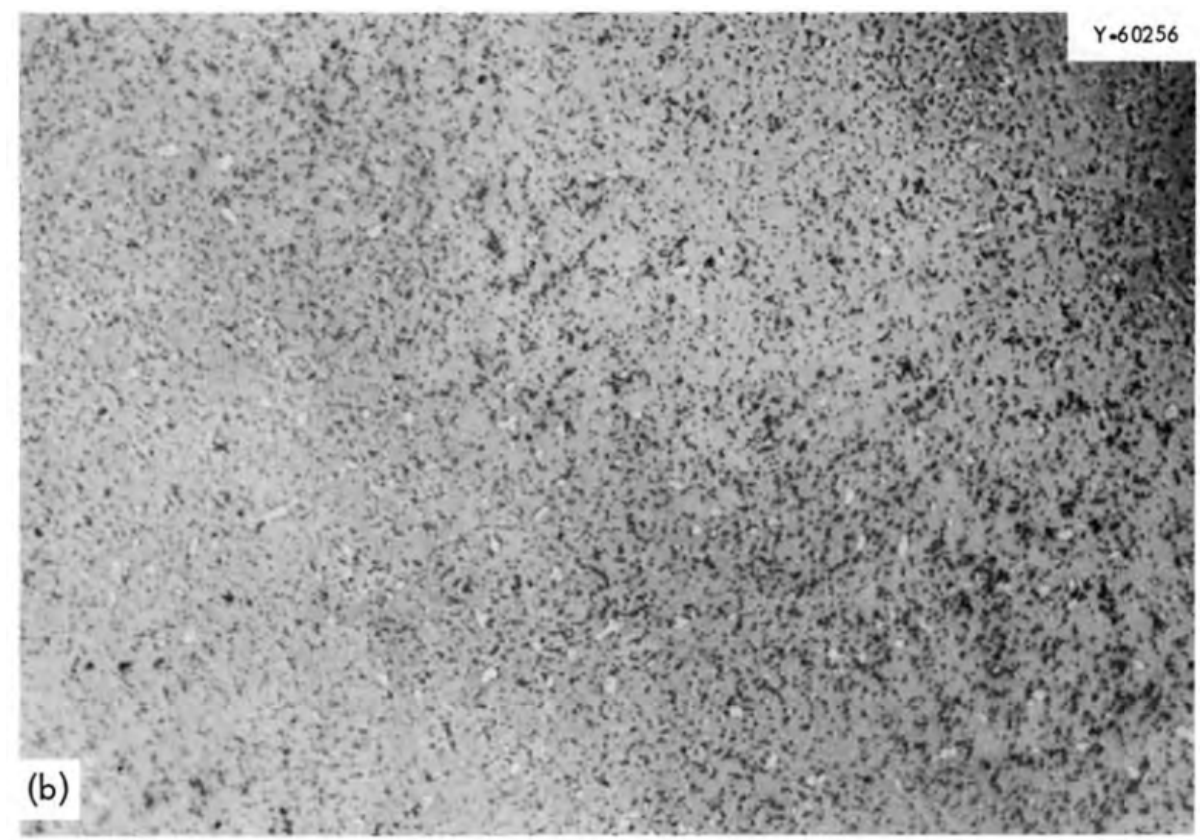

Figure 33 Hastelloy $\mathrm{N}$ was fabricated with ${ }^{14} \mathrm{C}$, which appears dark in the autoradiograph, while precipitates have light contrast. Note that the figure was resized from the original and the original had no scale bar, so the sizes of the features are unknown. Reproduced from Ref. [5].

The MSRE era data primarily consist of (1) surveillance samples that were exposed in the MSRE, and eventually components of the shutdown MSRE, which primarily consist of the original Hastelloy N alloy and graphite; and (2) samples that were irradiated in the Oak Ridge Reactor (ORR) or the Experimental Test Reactor (ETR) in Idaho concurrently while the MSRE was in operation, which consisted of the original Hastelloy $\mathrm{N}$ alloy, many modified alloys based on Hastelloy $\mathrm{N}$, and limited amounts of other metals and alloy systems. 

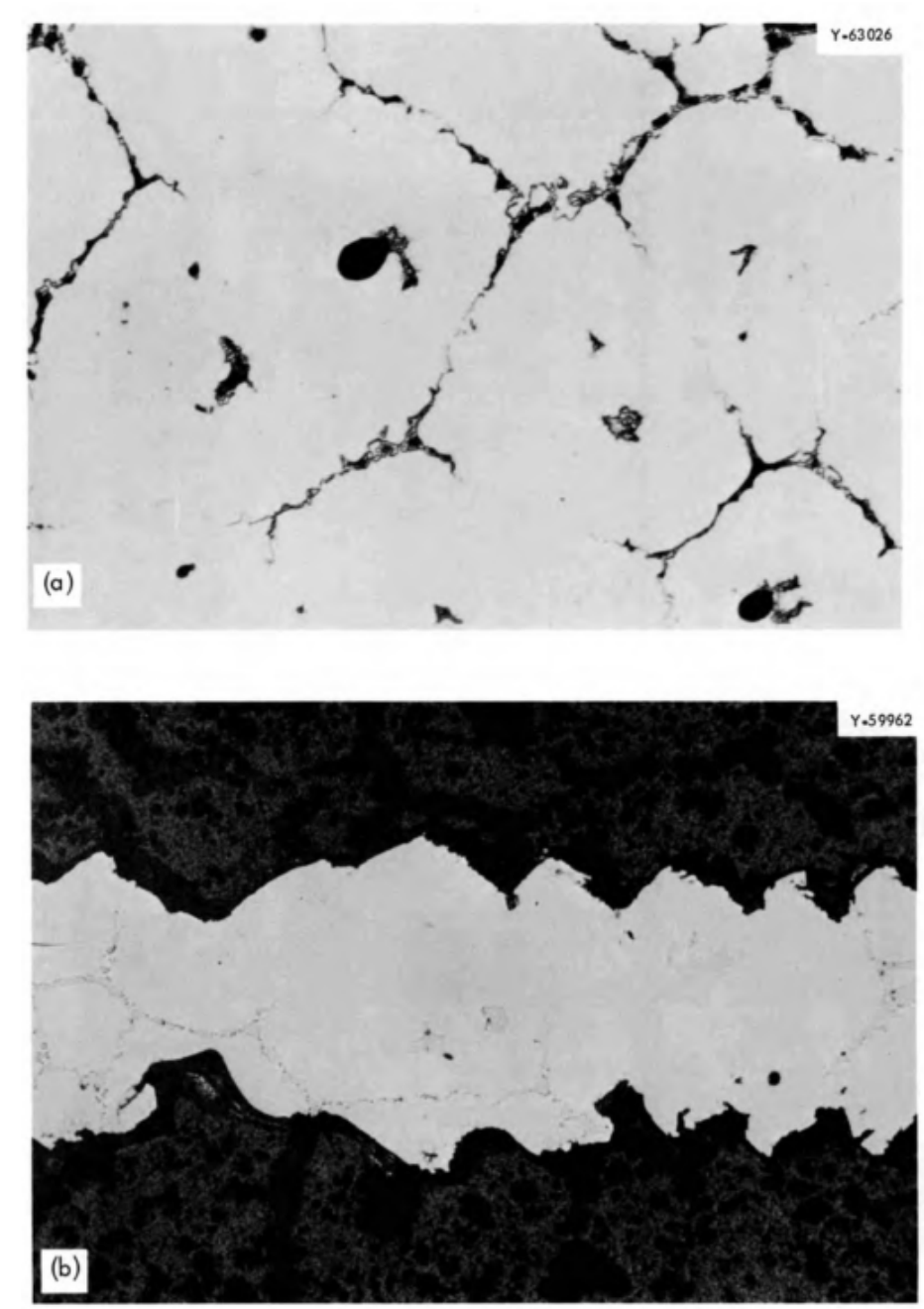

Figure 34 An example of missing detail and unidentifiable features in the microscopy from the MSRE project. Note that the figure was resized from the original and the original had no scale bar, so the sizes of the features are unknown. Reproduced from Ref. [5].

\subsubsection{Irradiation of base Hastelloy $N$ in test reactors}

A Hastelloy $\mathrm{N}$ heat was fabricated consisting of $\mathrm{Mo}, \mathrm{Cr}, \mathrm{Fe}, \mathrm{Si}, \mathrm{Mn}, \mathrm{V}$, and $\mathrm{Ni}$ at 16.87, 7.43, 3.35, $0.60,0.550 .26$, and balance wt \%, respectively. It also contained minor elements such as $\mathrm{C}, \mathrm{W}, \mathrm{P}$, $\mathrm{S}, \mathrm{Al}, \mathrm{Ti}, \mathrm{B}, \mathrm{Co}$, and $\mathrm{Cu}$ at $<0.1 \mathrm{wt} \%$ [6]. This Hastelloy $\mathrm{N}$ was neutron irradiated in the ORR in 1965 to a fast fluence of $\sim 7 \times 10^{20} \mathrm{n} / \mathrm{cm}^{2}(\mathrm{E}>1 \mathrm{MeV})$ and a thermal fluence of $\sim 9 \times 10^{20} \mathrm{n} / \mathrm{cm}^{2}$ at $700^{\circ} \mathrm{C}$. The samples were tensile tested at RT and at temperatures of $100-800^{\circ} \mathrm{C}$ in $100^{\circ}$ intervals [6]. For all test temperatures, the yield stress (YS) was not strongly changed by irradiation. The UTS was similar for the unirradiated and irradiated samples for test temperatures up to $400^{\circ} \mathrm{C}$; but starting at $500^{\circ} \mathrm{C}$, the irradiated UTS was noticeably less than the unirradiated value. The pattern was similar for the uniform elongation (UE) and total elongation (TE, also referred to as strain to fracture) with both of those values being significantly smaller for the irradiated materials at test temperatures of $500^{\circ} \mathrm{C}$ and above [6]. Thus, Hastelloy $\mathrm{N}$ irradiated at $700^{\circ} \mathrm{C}$ showed good mechanical strength and ductility at low deformation temperatures (RT to $\sim 500^{\circ} \mathrm{C}$ ). However, irradiated Hastelloy $\mathrm{N}$ showed decreases in ductility and true tensile strength at low strain rates and elevated deformation 
temperatures $\left(\geq 500^{\circ} \mathrm{C}\right)$ as a result of intergranular failure; irradiated samples with low ductility showed intergranular fracture rather than transgranular fracture [6].

Post-irradiation heat treatment of Hastelloy $\mathrm{N}$ at $1175^{\circ} \mathrm{C}$, which is the recommended solid solution temperature, did not produce better ductility. This indicated that the cause of the embrittlement was thermally stable and could not be healed at this temperature to improve ductility [6]. One of the possible causes for Hastelloy $\mathrm{N}$ embrittlement after thermal neutron irradiation is the localized $\mathrm{He}$ at grain boundaries due to the ${ }^{10} \mathrm{~B}(\mathrm{n}, \alpha)^{7} \mathrm{Li}$ capture reaction, with boron $(\mathrm{B})$ present as a common impurity in the material. Martin et al. provide other references and supporting data for the theory of embrittlement by He bubbles, but they admit that "the data generated, to date, is indirect evidence" [6]. Assuming He generation is the cause for embrittlement of irradiated Hastelloy N, a few remedies were suggested for lowering the B content at grain boundaries [6]. These involve lowering the average concentration by electron-melting, forming stable B-precipitates within grains, and increasing the number of grain boundaries to lower the concentration at grain boundaries [6].

In the next test reactor irradiation in 1968, Hastelloy N vacuum-melted heats 5911 and 6252 with five different pre-irradiation heat treatments were irradiated in the ORR to simultaneous $2.3 \times 10^{20}$ $\mathrm{n} / \mathrm{cm}^{2}$ thermal and $1.9 \times 10^{19} \mathrm{n} / \mathrm{cm}^{2}$ fast $(E>2.9 \mathrm{MeV})$ fluences at 650 and $760^{\circ} \mathrm{C}$ [7]. The vacuum melting process was used in an attempt to reduce the $B$ content in the materials. After irradiation, the samples were tested in creep and tensile tests at selected temperatures, including 550, 600, $650,760^{\circ} \mathrm{C}$. To try to remove the variable of thermal aging in the irradiated materials, the unirradiated samples were also held at 650 or $760^{\circ} \mathrm{C}$ for $1080 \mathrm{~h}$ to match the time the irradiated materials were in the reactor. Creep-rupture life and ductility (both creep and tensile) decreased after neutron irradiation at 650 to $760{ }^{\circ} \mathrm{C}$ [7]. There were slight differences in the behavior depending on the heat and the pre-irradiation heat treatment; but, for example, a sample in the unirradiated condition and tensile tested at $760^{\circ} \mathrm{C}$ had $13 \%$ TE whereas the corresponding irradiated sample had 1\% TE [7]. The TE for all materials decreased with increasing test temperature. Although these heats had lower than normal $B$ contents, the authors attributed the irradiated loss of ductility to the production of $\mathrm{He}$ in the metal due to ${ }^{10} \mathrm{~B}(n, \alpha)^{7} \mathrm{Li}$ transmutation [7].

In a later experiment in 1970, the ORNL researchers irradiated base Hastelloy $N$ at the ETR in Idaho and the ORR at ORNL [8]. There were no alloying additions in this set of experiments; but the Fe and Mo amounts were varied, and several different melt treatments were used in the fabrication to change impurity concentrations, including B and oxygen. The irradiations in the two reactors were conducted at similar fluences and were considered equivalent; any effects of flux or energy spectrum differences between the two reactors were not considered. The ETR had thermal and fast (E>1 MeV) fluxes each equal to $3.2 \times 10^{14} \mathrm{n} /\left(\mathrm{cm}^{2} \mathrm{~s}\right)$; the ORR had a peak thermal flux of $6 \times 10^{13} \mathrm{n} /\left(\mathrm{cm}^{2} \mathrm{~s}\right)$ and a peak fast $(E>2.9 \mathrm{MeV})$ flux of $5 \times 10^{12} \mathrm{n} /\left(\mathrm{cm}^{2} \mathrm{~s}\right)$ [8]. The purpose of these irradiations was to examine the effects of irradiation temperature; so between the two reactor experiments, irradiations were carried out at $\sim 40, \sim 150, \sim 600, \sim 650, \sim 700, \sim 760^{\circ} \mathrm{C}$. The rupture life of the material was reduced by irradiation, and the degradation was worse for the material irradiated at the highest temperature $760^{\circ} \mathrm{C}$ [8]. The creep properties of each of the four tested heats were somewhat different; and as the data were presented over many images and with several variables changing, it is difficult to compare their behavior in detail. It is clear that each heat had noticeably different behavior.

The air-melted Hastelloy $\mathrm{N}$ had silicon-rich $\mathrm{M}_{6} \mathrm{C}$ carbide stringers (the $\mathrm{M}_{6} \mathrm{C}$ can be $[\{\mathrm{Ni}, \mathrm{Si}$, $\left.\mathrm{Fe}\}_{3}\{\mathrm{Mo}, \mathrm{Cr}\}_{3}\right] \mathrm{C}$ ) [8]. The precipitate composition may have been determined by electron microprobe analysis, but throughout Ref. [8], the detail of the precipitates is often discussed 
without corresponding data being presented. It is unclear if the precipitate analysis was published in another report, or if the precipitate analysis is an educated guesses based on the authors' familiarity with the alloy. When the unirradiated alloy was annealed at $650-870^{\circ} \mathrm{C}$, finer $\mathrm{M}_{6} \mathrm{C}$ precipitates formed on the grain boundaries [8]. The vacuum-melted version of Hastelloy $\mathrm{N}$ had lower silicon and thus fewer carbide stringers and more of the $\mathrm{M}_{2} \mathrm{C}$ carbides according to Ref. [8]. In the SEM images (example shown in Figure 35) presented in the paper, some grain boundaries and darker regions (likely precipitates) are seen, but no additional information about the precipitate character could be gained from the SEM data. Also, Figure 35 is an example of the low-contrast images from the MSRE era; almost all the features are uniformly gray and are viewed at low magnification. There are a few transmission electron microscopy (TEM) images in the paper that show a precipitate and several small cavities, which it is reasonable to assume are He bubbles (Figure 36). Again, based on these data, it is clear that there is some type of cavity and some type of precipitate. But without further analysis, there is no way to tell if the cavities are He bubbles and no way to determine the phase, elemental composition, and relationship to the matrix of the precipitate. Even if the cavities are He bubbles, that does not prove that they were the key embrittlement factor. What are also missing in the analysis are focused, high-magnification images of the representative microstructures before and after irradiation. Without knowledge of the unirradiated microstructure, it is difficult to determine the effects of irradiation on these materials. Additionally, today's higher-resolution TEM imaging would be able to uncover more information about the precipitates, grain boundary character, bubbles or cavities, and irradiation damage such as voids and dislocation loops.
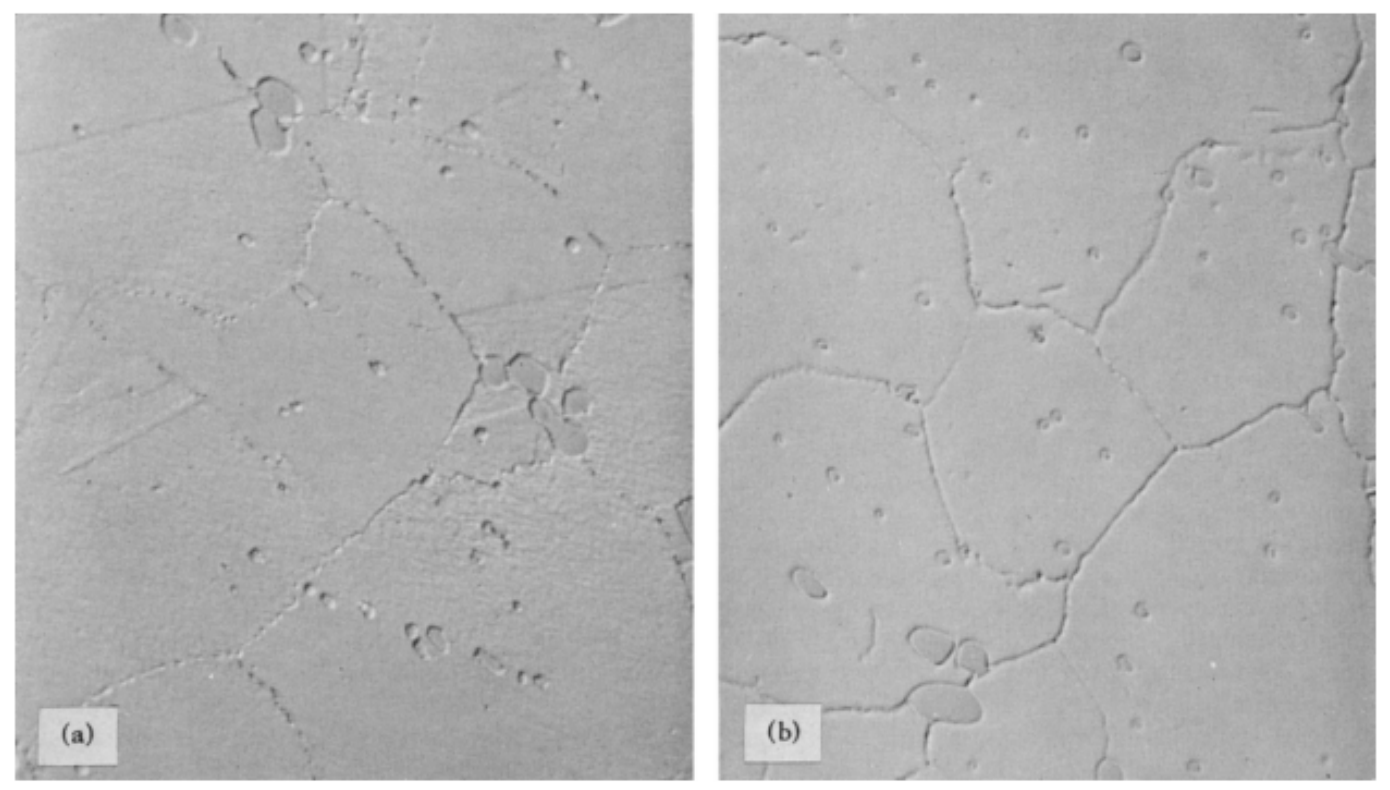

Figure 35 Some precipitates or inclusions are seen, but from this data the phase or nature of the precipitates cannot be determined. Note that the image has been resized from the original publication and the original had to scale bar, so precise sizes of features are unknown. Reproduced from Ref. [8]. 


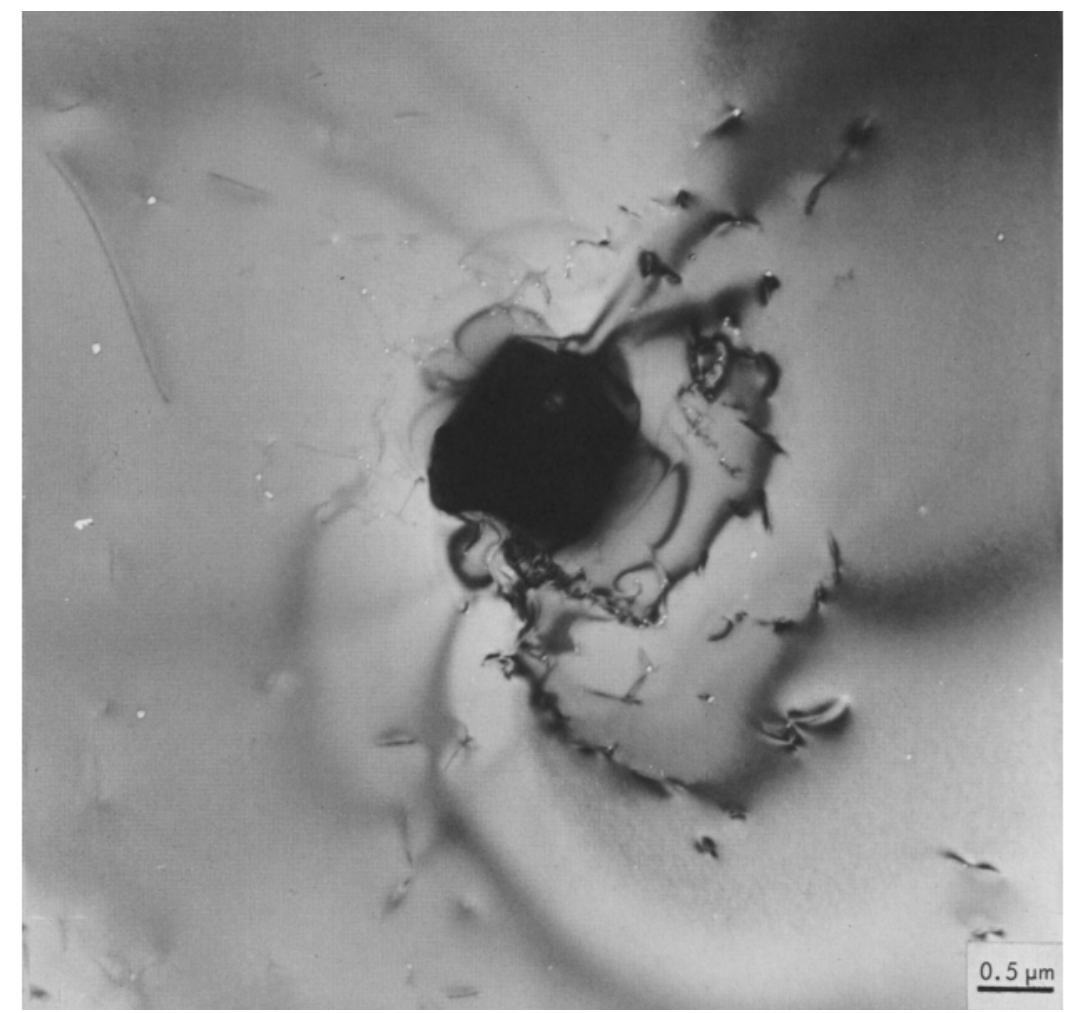

Figure 36 This is one of the few TEM images from the MSRE era; it shows a precipitate of unknown type and some small cavities that may be helium bubbles. Reproduced from Ref. [8].

The authors postulated that the mechanical property change after irradiation critically depended on changes in the carbides at different irradiation temperatures [8]. If the irradiation temperature is such that the carbides are stable, the creep properties will not change much; but if the irradiation temperature is high enough that the carbides are unstable, the creep properties will degrade. Additionally, they postulate that the He bubbles are another important source of property degradation after irradiation [8]. Although the authors did observe some small cavities after irradiation, which could logically be He bubbles, their presence does not prove that they had a large impact on the mechanical properties. The authors recommend adjusting the alloy composition to produce more MC-type carbides because the coarse carbides lead to worse mechanical properties [8].

Boron is an impurity in Hastelloy N. Thermal neutrons cause the reaction ${ }^{10} \mathrm{~B}(\mathrm{n}, \alpha)^{7} \mathrm{Li}$. Boron may be beneficially involved in forming carbides in Hastelloy $\mathrm{N}$, so it should not be completely eliminated [8]. The authors in Ref. [8] postulate that the B is bound in the carbides and that the $\mathrm{He}$ produced from thermal neutron reactions goes to the grain boundaries and weakens them. While both theories are logical, neither could be observed at the time. Also, the authors postulate that only a very small amount of $B$ in the alloy is enough to cause $\mathrm{He}$ embrittlement [8], but this theory could not be proved at the time and does not consider other mechanisms of embrittlement that could be acting in the alloy. Some differences in the carbides were observed after irradiation, but it was not determined how much of the change was from irradiation and how much from the extended hold at elevated temperature [8]. The authors did not use the measure of dpa, which would have been helpful for comparing the relative damage from the two different test reactors 
and comparing results with those from the earlier test reactor experiments. Additionally, the different fluxes of the two research reactors were not considered to impact the results.

The microscopy done at the time in Ref. [8] was only low-magnification (up to 1000x) surface evaluation; and the images have very low dynamic range, so that they are almost uniformly grey with a few slightly darker or slightly lighter features. Although this magnification is appropriate to see several grains and precipitates in one image, no scale bars are given. Since the original image was likely scanned and possibly resized, and then the pdf of the scanned report was again resized on a modern-day computer screen, it is quite difficult to confidently estimate the sizes of the features in the images. These authors (and it seems that generally reports from the MSRE era have the same trend) do not present any sort of statistics or measures from the images such as average size of precipitates or histograms of grain sizes. Instead, it is common that qualitative statements along the lines of "the carbides were larger" are made. Additionally, the reports from the time do not (and likely could not) include any visual aids such as arrows on the figures to indicate the important points that they discuss. This can make it difficult to connect what the author is describing to what is shown in the image. For instance, in examining a poor-quality image with no additional indicators on it, it is difficult to determine if a particular darker spot in the image could be a carbide, a small pore, or a surface imperfection from polishing.

\subsubsection{Irradiation results from the MSRE}

The MSRE operated from 1965 to 1969 with an average temperature in the core of $650^{\circ} \mathrm{C}$ and over 20,000 operating hours [9]. Examinations of materials in the MSRE included four groups of surveillance samples, loop tests, and, after the shutdown of the reactor, destructive examination of the MSRE components themselves. Surveillance specimens located in the core were referred to as "core samples" (exposed to neutrons, temperature, and salt with fission products). Those located in the cell atmosphere close to the reactor vessel were referred to as "cell samples" (exposed to some neutron irradiation and temperature but no salt or fission products). Those in contact with non-fissioning fuel salt at elevated temperature were referred to as "control samples" (not exposed to fission products or neutrons) [9]. These samples included graphite, standard Hastelloy $\mathrm{N}$ of various heats, and eventually modified Hastelloy $\mathrm{N}$ alloys. The standard Hastelloy $\mathrm{N}$ had the nominal composition of $\mathrm{Ni}, 16 \% \mathrm{Mo}, 7 \% \mathrm{Cr}, 5 \% \mathrm{Fe}$, and $0.05 \% \mathrm{C}$. The surveillance samples were examined visually and under a microscope and then tested in creep at $650^{\circ} \mathrm{C}$ and tensile at $25^{\circ} \mathrm{C}$ and $650^{\circ} \mathrm{C}$; microscopy of selected samples was conducted after the mechanical tests. Based on previous work with Hastelloy $\mathrm{N}$, the expected behavior of Hastelloy $\mathrm{N}$ in a tensile test at elevated temperature is to form some intergranular cracks before eventually failing by intergranular failure [9]. For tensile tests at $25^{\circ} \mathrm{C}$, the normal behavior was transgranular failure without any additional cracks beyond the failure point [9]. Many of the core surveillance samples developed additional cracks when tensile tested at $25^{\circ} \mathrm{C}$, which indicated that the MSRE conditions were degrading the grain boundaries; this phenomenon was the focus of much of the examination of the surveillance samples [9].

\section{$\underline{\text { First group surveillance }}$}

The surveillance specimens of structural materials, unclad graphite (the moderator), and Hastelloy $\mathrm{N}$ cladding irradiated under the MSRE program showed that mechanical properties of Hastelloy $\mathrm{N}$ were adequate for MSRE operation after $7823 \mathrm{MWh}$ of operation completed in 1966 [10]. These samples were irradiated at $645 \pm 10^{\circ} \mathrm{C}$ for $4800 \mathrm{~h}$ at a thermal dose of $1.3 \times 10^{20} \mathrm{n} / \mathrm{cm}^{2}$. The reactor was fueled by a molten fluoride salt $\left(\mathrm{LiF}, \mathrm{BeF}_{2}, \mathrm{ZrF}_{4}\right.$, and $\mathrm{UF}_{4}$ at, respectively, 65, 29.1, 5, and $0.9 \mathrm{~mol} \%$ ), and no significant corrosion was detected in the surveillance materials. A C-rich layer, 
probably an $\mathrm{M}_{\mathrm{x}} \mathrm{C}$, with a depth of $0.001-0.002$ in. was observed where Hastelloy $\mathrm{N}$ and graphite were in contact [10]. A reduction in both high- and low-temperature ductility was observed in the Hastelloy $\mathrm{N}$. The low-temperature ductility reduction was explained by the formation of intergranular $\mathrm{M}_{6} \mathrm{C}$ as a result of radiation-induced nucleation and growth [10]. The lowest ductility was observed in parts used for the top and bottom heads of the MSRE. Hastelloy N typically has UE almost equal to the TE, so when TE is reduced, the UTS is also reduced. Even though the creep-rupture strength and ductility of control Hastelloy $\mathrm{N}$ samples can be increased by stressrelieving annealing at $871^{\circ} \mathrm{C}$, as was used for materials in the MSRE, slight reductions in rupture strength and ductility were observed after long exposure under MSRE operating conditions at $650^{\circ} \mathrm{C}$. Surveillance specimens from the core showed less creep-rupture life, and therefore a decrease in fracture strains, than in the control specimens [10]. Additionally, the mode of failure was different, with the core samples having more intergranular fractures at $25^{\circ} \mathrm{C}$ tensile tests, while the control samples had more transgranular failure at that condition [9]. The irradiated and strained material had numerous surface cracks (Figure 37).

Concurrently, the cell samples were exposed to a thermal fluence of $1.3 \times 10^{19} \mathrm{n} / \mathrm{cm}^{2}$ in a $\mathrm{N}_{2}$ atmosphere with a 2 to $5 \% \mathrm{O}_{2}$ environment. The results showed no nitriding or significant oxidation in the specimens [11]. These specimens were irradiated outside the core, so they received less fluence than the first group of core samples. The cell samples' mechanical properties, tensile fracture strain, and creep-rupture life and ductility decreased after irradiation [11]. The mechanical properties were only slightly worse in these Hastelloy $\mathrm{N}$ specimens when the thermal dose was increased from $1.3 \times 10^{19}$ to $1.3 \times 10^{20} \mathrm{n} / \mathrm{cm}^{2}$ [11].

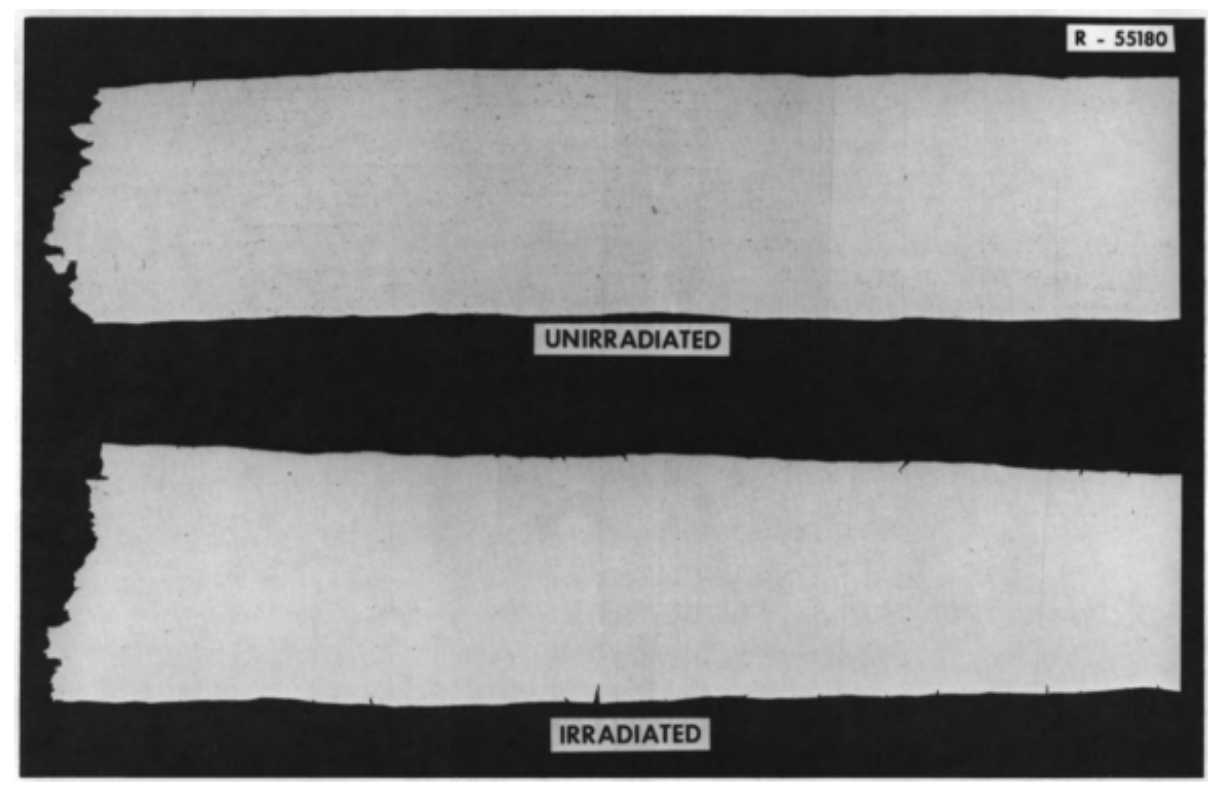

Figure 37 Hastelloy $\mathbf{N}$ from the first group of surveillance samples from the core of the MSRE developed surface cracks after bein $\mathrm{g}$ strained. The scale of the image is unknown. Reproduced from Ref. [9].

\section{Second group surveillance}

The second group of surveillance samples was exposed for a similar time as the first group but to about three times the neutron fluence, a total of $4.1 \times 10^{20} \mathrm{n} / \mathrm{cm}^{2}[9,11]$. This second group included some modified alloys. In the case of zirconium ( $\mathrm{Zr}$ )- and Ti-modified alloys, better 
properties were observed in the annealed materials with coarser grain sizes after irradiation in the reactor core [11]. The control samples had few to no grain boundary surface cracks in tensile tests, but intergranular cracking near the specimen surfaces was observed in the core specimens [11]. Despite the intergranular surface cracks on the modified alloys, the failures in tensile testing were mostly transgranular, showing a slight improvement in resisting failure from the intergranular cracking [9]. These specimens had slightly better mechanical properties compared with the standard alloy, and their corrosion resistance was acceptable [11]. The important finding was that these modified alloys had many different alloying elements-including $\mathrm{Fe}, \mathrm{Mo}, \mathrm{Si}, \mathrm{Zr}$, and $\mathrm{Ti}$-but all still formed the intergranular cracks; so none of these elements helped stop the cracking [9]. An example of surface cracks on a Hastelloy $\mathrm{N}$ modified with $\mathrm{Zr}$ is shown in Figure 38.
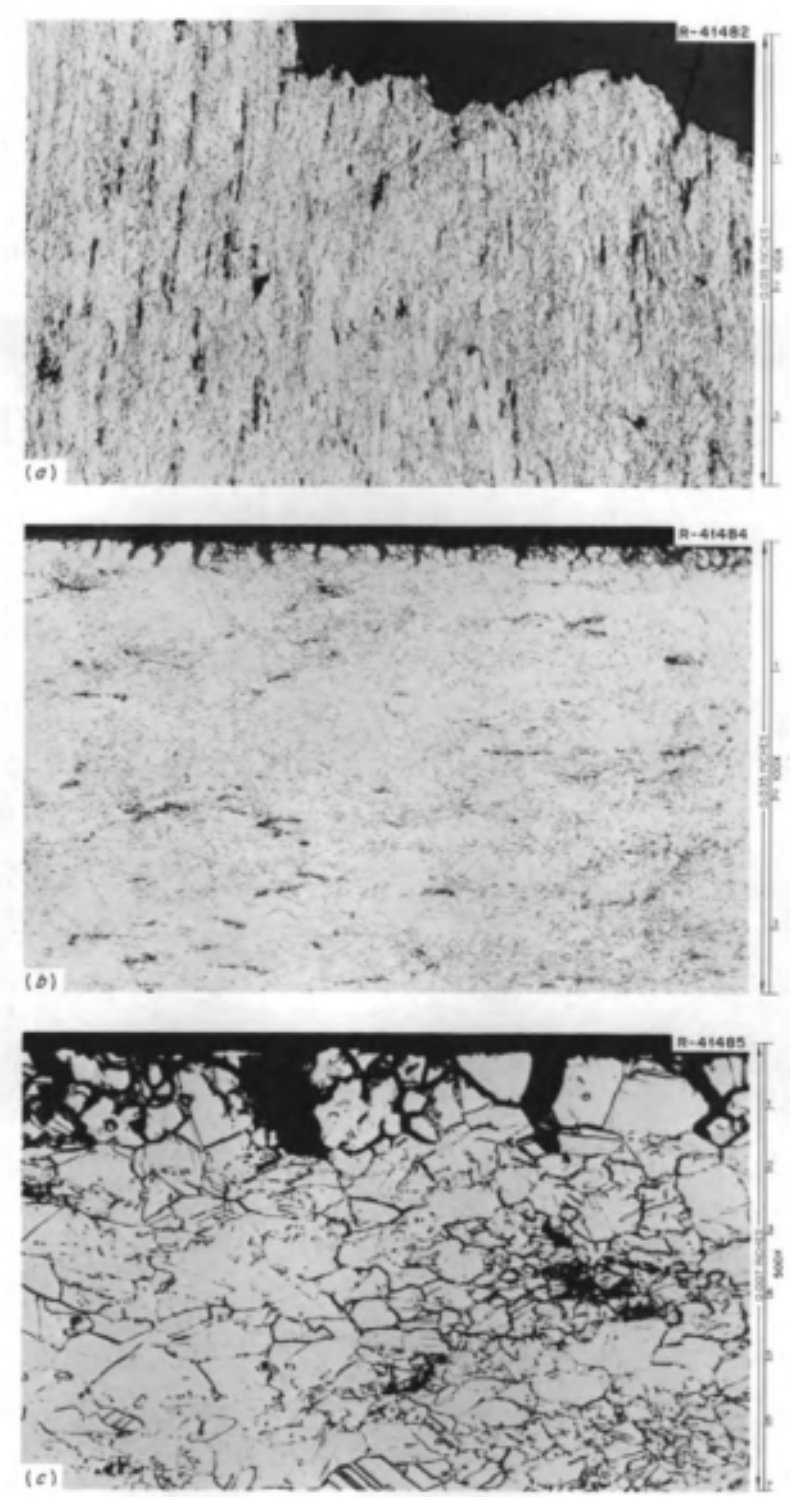

Figure 38 The materials from the second group of surveillance samples in the MSRE included several versions of Hastelloy $\mathbf{N}$ modified with different alloying elements. None of the modified alloys had reduced surface cracking. Heights of the image sections are (a) 0.035 inches, (b) 0.035 inches, and (c) 0.007 inches. Reproduced from Ref. [9]. 


\section{Third group surveillance}

Hastelloy $\mathrm{N}$ specimens were irradiated to $9.4 \times 10^{20} \mathrm{n} / \mathrm{cm}^{2}$ and exposed to the fuel salt at $650^{\circ} \mathrm{C}$ (core samples), and to $2.6 \times 10^{19} \mathrm{n} / \mathrm{cm}^{2}$ outside the vessel and exposed to nitrogen and $2-5 \% \mathrm{O}_{2}$, at $650^{\circ} \mathrm{C}$ (cell samples) [12]. This third group included some standard Hastelloy $\mathrm{N}$ and some modified alloys and were exposed 2-4 times as long as the first group of surveillance samples [9]. Some of the standard Hastelloy $\mathrm{N}$ core samples had intergranular cracks easily visible in the unstrained condition, whereas the control samples had no intergranular cracks in the unstrained condition (Figure 39) [9]. The core and cell samples showed decreased fracture strain when tested at $25^{\circ} \mathrm{C}$ which was attributed to carbide precipitation, and above $500^{\circ} \mathrm{C}$, believed to be because of the presence of $\mathrm{He}$ from the ${ }^{10} \mathrm{~B}(\mathrm{n}, \alpha)^{7} \mathrm{Li}$ transmutation [12]. Two modified Hastelloy $\mathrm{N}$ alloy heats irradiated in the core to a thermal fluence of $5.3 \times 10^{20} \mathrm{n} / \mathrm{cm}^{2}$ showed better postirradiation properties than standard Hastelloy $\mathrm{N}$, but the modified alloys in the core had the same problem of intergranular cracking as did the standard Hastelloy N [12].
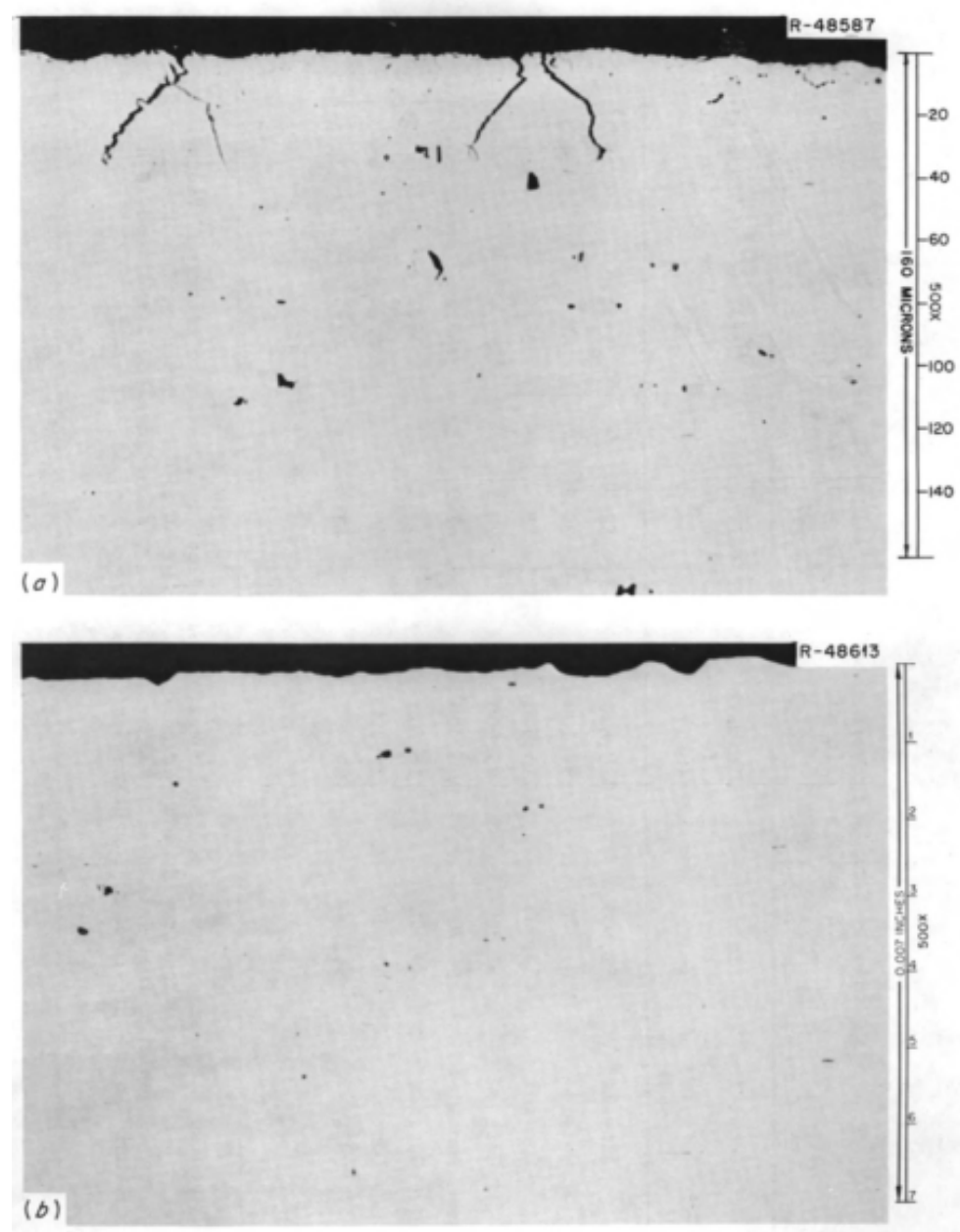

Figure 39 Example of a Hastelloy $\mathrm{N}$ sample from the third surveillance group from the MSRE. (a) Material exposed to the MSRE core has surface cracks evident as-removed from the reactor and before being strained. Height of the image is 160 microns. (b) material from the control group exposed to 11,933 hours above $550^{\circ} \mathrm{C}$ does not show cracks. Height of the image is 0.007 inches. Reproduced from Ref. [9]. 


\section{Fourth group surveillance}

Hastelloy $\mathrm{N}$ irradiated at $650^{\circ} \mathrm{C}$ up to a thermal fluence of $1.5 \times 10^{21} \mathrm{n} / \mathrm{cm}^{2}$ and a fast fluence (> $50 \mathrm{keV}$ ) of $1.1 \times 10^{21} \mathrm{n} / \mathrm{cm}^{2}$ showed decreased mechanical properties believed to be due to He production from the ${ }^{10} \mathrm{~B}(\mathrm{n}, \alpha)^{7} \mathrm{Li}$ transmutation; therefore, changes in the chemical composition of the material could produce better post-irradiation properties [13]. Selective removal of $\mathrm{Cr}$ caused some corrosion of Hastelloy $N$ [13]. The same intergranular surface cracks were observed on the fourth group of surveillance samples, very similar to all the previous surveillance sample sets [9]. Auger electron spectroscopy found Te, S, and Mo concentrated on the grain boundaries, which may be correlated with the intergranular cracking [9]. The reductions in UTS and TE for the fourth group were thought to be caused by the coarse carbides forming over the extended time at elevated temperature, with irradiation possibly assisting the process. All of the cell surveillance samples in the different groups developed an oxide layer and had reduced UTS and TE compared with unirradiated material, but they did not show the intergranular surface cracks. The cell samples' degradation was attributed to the formation of the coarse $\mathrm{M}_{6} \mathrm{C}$-type carbides from the extended elevated-temperature exposure [9].

\section{MSRE components}

Parts of the MSRE were disassembled at the completion of operation for destructive analysis and testing. The MSRE components were exposed to fissioning salt and neutron irradiation longer than any of the surveillance samples. Components exposed to different neutron fluence, salt types, and temperatures were examined [9]. Because of the difficulty of fabricating test samples from the MSRE components, a novel tube tensile-type test was developed to give a qualitative indication of ductility [9]. The MSRE components confirmed the same results seen in the surveillance samples. Those materials exposed to salt with fission products formed intergranular surface cracks. Those materials exposed to significant neutron fluence had reduced ductility (qualitatively measured with the tube tensile-type test) after irradiation.

\section{Elemental analysis of MSRE surveillance samples and components}

An electron microprobe analyzer was used to measure elements in cross sections of MSRE materials, but the resolution was limited to one data point every $\sim 8-12 \mu \mathrm{m}$ and penetrating $\sim 80$ $\mu \mathrm{m}$ deep into the material [9]. Based on this and other elemental analyses, the researchers found that $\mathrm{Te}, \mathrm{Ce}, \mathrm{Sb}, \mathrm{Cs}, \mathrm{S}$, and $\mathrm{P}$ appeared to be concentrated at the grain boundaries, and significant amounts of $\mathrm{Te}, \mathrm{Sb}, \mathrm{Ru}$, and Tc were on the metal surfaces. They acknowledged at the time that their detection methods were not sufficiently sensitive, so they considered the possible effects of many different fission products that could be expected to deposit on the metal, even ones that were not detected [9]. Further tests were conducted with many elements, and the findings showed that (1) sulfur and selenium sometimes had negative effects on Hastelloy $N$; (2) Te had negative effects in almost all the tests; (3) As, Sb, Sr, Zn, Cd, Ru, Tc, Mo, Rh, Zr, and Ce did not appear to have negative effects; and (4) $\mathrm{Nb}$ could deposit but could be beneficial to $\mathrm{Ni}$ alloys. In conclusion, the family of S, Se, and Te were regarded as the elements most likely to harm Ni alloys; of these, Te appeared to be the worst, so the future experiments all concentrated on $\mathrm{Te}$ [9].

\section{Key observations from the MSRE surveillance samples and components}

Hastelloy $\mathrm{N}$ surveillance samples in the core, control, and cell zones all formed brittle $\mathrm{M}_{6} \mathrm{C}$ type precipitates that contributed to fractures at $25^{\circ} \mathrm{C}$ being intergranular instead of transgranular; irradiation accelerated this precipitation because it was worse in the core samples [9]. The modified alloys that included $\mathrm{Zr}$ and $\mathrm{Ti}$ (and other alloying elements) were designed to form more 
MC-type carbides than $\mathrm{M}_{6} \mathrm{C}$, and it appeared that this was successful [9]. Although many lowmagnification ( $500 \times$ or less magnification) microscopy images are presented that show features such as grain boundaries or surface cracks, it was unclear from the references reviewed what data were used to determine the nature of the carbides and precipitates in the materials. It was unclear if visual features such as the apparent sizes of the precipitates or other data that were not published in the cited references were used by the MSRE team to make conclusions about the population of $\mathrm{MC}$ versus $\mathrm{M}_{6} \mathrm{C}$ precipitates, for example.

From observing all the different surveillance samples and MSRE components, it was clear that irradiation alone was not the cause of the surface cracking; it occurred only on material that was exposed to salt with fission products in it [9]. Coolant salt did not cause the surface cracks; flowing salt was not necessary to form the cracks; Cr corrosion was not the cause of the cracks; and exposure to salt mist or gas caused less cracking than liquid fuel salt. The $\mathrm{S}$, Se, and Te family elements were the only ones found to cause cracking in Hastelloy $\mathrm{N}$, and stress plus Te exposure increased the severity of the intergranular surface cracks [9]. Other classes of materials were also tested with Te, and the results showed that (1) Fe-based alloys, copper, and Monel did not form cracks; (2) Ni or Co-based alloys with more than $\sim 15 \% \mathrm{Cr}$ ( $20 \% \mathrm{Cr}$ probably is needed) were resistant to cracking; and (3) Hastelloy $\mathrm{N}$ modified with $\mathrm{Nb}$ was resistant to cracking [9]. Later, it was found that keeping the salt in a reducing state might prevent surface cracking; so if the salt condition can be controlled, Hastelloy $\mathrm{N}$ versions modified for improved neutron irradiation resistance could be used in a reactor [14]. There appears to be a complicated relationship between temperature, salt chemistry, and neutron irradiation that results in degradation of Hastelloy $\mathrm{N}$ type materials. Testing new materials for possible use in MSRs must consider the possible synergies among these conditions that could lead to degradation of materials. Although potential solutions for irradiation embrittlement and intergranular cracking were identified during the MSRE project, the limitations of analysis tools at the time prevented much understanding of the mechanisms. Using present-day microscopy and analysis tools would allow for the MSRE theories to be evaluated and might suggest new pathways for materials improvement.

\subsubsection{Modified Hastelloy N irradiated in ORR and ETR}

From operation and surveillance specimens irradiated and exposed in the MSRE, two issues were found with Hastelloy $N$. One issue was that high-temperature neutron irradiation reduced the ductility of Hastelloy $N[3,14]$. The second issue was that fission products present in the salt, notably Te, were involved in creating shallow surface cracks into the grain boundaries of Hastelloy $\mathrm{N}$ [14]. Tellurium cracking is discussed here because a useful material for an MSR must simultaneously resist both irradiation embrittlement and Te cracking; solutions for one aspect that exacerbate the other are not desirable.

After neutron irradiation in the MSRE, Hastelloy $\mathrm{N}$ had reduced creep-rupture life and tensile ductility [14]. The early results from the MSRE showed unexpected brittle behavior at low temperatures after irradiation in the MSRE and prompted more investigation into the irradiated properties and thermal aging of Hastelloy $\mathrm{N}$ [3]. The ORNL team of McCoy et al. believed that the main cause of this irradiation embrittlement in Hastelloy $\mathrm{N}$ was transmutation-produced $\mathrm{He}$ in the material migrating to the grain boundaries and weakening them [14]. The raw Fe and Ni materials used to produce alloys including Hastelloy $\mathrm{N}$ contain ${ }^{10} \mathrm{~B}$ as an impurity, which transmutes with thermal neutrons to release $\mathrm{He}$ [14]. Additionally, B can cause weld cracking, so its presence in the alloy is undesirable [3]. Also, the isotope ${ }^{58} \mathrm{Ni}$ can release He by a two-step nuclear reaction [14]. Elements $\mathrm{Ni}, \mathrm{Mo}$, and Fe react with fast neutrons to release He as well [3]. The neutron irradiation damage was worse with higher-thermal flux experiments than with fast flux experiments, so ${ }^{10} \mathrm{~B}$ appeared to be more damaging than the elements that lead to fast neutron 
transmutations [3]. Even when alloys were fabricated with care to reduce B content to 1-5 ppm, the alloys were still embrittled after neutron irradiation [3]. This result indicates that either the material has a low He threshold for mechanical property degradation, or other factors beyond $\mathrm{He}$ contributed to the degradation after neutron irradiation. The ORNL group focused on adding alloying elements that would change the types of carbide precipitates in Hastelloy $\mathrm{N}$ with the goal of better trapping $\mathrm{He}$ at the precipitates and keeping it away from grain boundaries [14].

A modified version of the original Hastelloy $\mathrm{N}$ composition was developed to avoid forming the large carbide stringers; the modified alloy was nominally $\mathrm{Ni}, 12 \% \mathrm{Mo}, 7 \% \mathrm{Cr}, 0.2 \% \mathrm{Mn}$, and $0.05 \%$ $\mathrm{C}$ [15]. However, the modified Hastelloy $\mathrm{N}$ still had irradiation embrittlement issues, so the researchers wanted to further modify the alloy. The rationale for the additions was the assumption that the transmutation of $\mathrm{B}$ to $\mathrm{He}$ was the cause of the Hastelloy $\mathrm{N}$ embrittlement. The authors postulated that having the $\mathrm{B}$ bound to another element would also help prevent the transmuted $\mathrm{He}$ from going to grain boundaries, so they selected $\mathrm{Ti}, \mathrm{Zr}$, and $\mathrm{Hf}$ as additions because they form strong $\mathrm{MB}_{2}$ compounds ( $\mathrm{M}=\mathrm{Ti}, \mathrm{Zr}$, or Hf) [15]. It is unclear, and was unproved, whether having the $B$ bound in a compound had an effect on the final He placement throughout the metal. Helium is insoluble in metals, and fast diffusion is possible at temperatures relevant to MSRs; so it is unclear if the additions to bind the $\mathrm{B}$ had any effect on the transmuted He behavior. Additionally, the $\mathrm{M}_{6} \mathrm{C}$ type carbides present in standard Hastelloy $\mathrm{N}$ were undesirable, and the alloying elements might have helped those as well [15].

Alloys were made with additions of $\mathrm{Ti}, \mathrm{Zr}$, and $\mathrm{Hf}$ and were irradiated in the ETR at Idaho Falls, the ORR, and the MSRE [15]. Different fluxes, fluences, and neutron energy spectra of the different reactors were not considered at the time of the report. Before and after irradiation, the alloys were creep tested and tensile tested at selected temperatures. The researchers observed worse properties (e.g., TE) in cases when the material was irradiated at low temperatures and then tested at $760^{\circ} \mathrm{C}$, and in cases when the material was irradiated and tested at $700^{\circ} \mathrm{C}$ or above. Later results showed that $\mathrm{Hf}$ and $\mathrm{Zr}$ negatively impacted the weldability of Hastelloy $\mathrm{N}$ and so are not desirable additions. Also, Ti cannot be used unless the salt is in a reducing condition to avoid Te surface cracking. The additions did seem to improve the properties compared with the base Hastelloy $\mathrm{N}$, but the problem of embrittlement above $\sim 700^{\circ} \mathrm{C}$ persisted [15]. The hightemperature embrittlement was attributed to coarser carbides based on the TEM investigation; but the TEM images presented are blurry and have poor contrast, so it is difficult to see what features the authors saw. Additionally, it is unclear if TEM images of the unirradiated representative structure were taken, or if the materials were imaged only after irradiation. The SEM images of the microstructure also focused on the after-irradiation microstructure. Most were taken at 100x magnification and do not include a scale bar, so the sizes of features are difficult to determine.

These experiments showed that pre-irradiation heat treatment could be important for determining post-irradiation mechanical properties [15]. Although some improvement was seen with the $\mathrm{Ti}, \mathrm{Zr}$, and $\mathrm{Hf}$ additions, the hypothesis that these elements bonded to $\mathrm{B}$ and prevented $\mathrm{He}$ from going to the grain boundaries could not be measured at the time; therefore, the mechanism for the improvement was unknown. From this group of experiments, Ti was the best candidate for improving the irradiation properties of Hastelloy $\mathrm{N}$.

To study the irradiation effects, altered Hastelloy N-based materials were irradiated in the ORR and investigated via creep tests and some microscopy [14]. A Hastelloy N modified with $2 \% \mathrm{Ti}$ was irradiated in the ORR to thermal neutron fluence of $2-3 \times 10^{20} \mathrm{n} / \mathrm{cm}^{2}$ at $650^{\circ} \mathrm{C}$. The modified alloy did better in creep testing after irradiation than did standard Hastelloy $N$ [14]. The irradiated creep properties were good at 650 and $700^{\circ} \mathrm{C}$ but brittle at $760^{\circ} \mathrm{C}$. Some limited microscopy was 
done and found that the precipitates were primarily the MC type, but the details and distribution were complicated and depended on pre-irradiation heat treatment of the material. The brittle behavior at $760^{\circ} \mathrm{C}$ was attributed to coarsening of the precipitates [14]. At the time, the precipitates were identified as important, but high resolution microscopy was not available to confirm the theories. More information is needed using modern microscopy methods on the precipitates' detailed evolution with temperature and irradiation because they affected the mechanical properties. This modified Hastelloy $\mathrm{N}$ with $2 \%$ Ti showed good weldability [14].

The addition of from 0.15 to $1.2 \%$ Ti increased the YS of Hastelloy $\mathrm{N}$ but had no significant effect on the tensile ductility of the material [16]. YS increased for aged and prestrained samples too, while the ductility was dependent on alloy content, annealing temperature, and aging temperature. Carbides (monocarbide [MC] or $\mathrm{M}_{2} \mathrm{C}$-type) influenced Hastelloy $\mathrm{N}$ material mechanical properties such as creep and tensile properties [16]. While low-Ti or high-temperature $\left(760^{\circ} \mathrm{C}\right)$ aged alloys favored $\mathrm{M}_{2} \mathrm{C}$-type carbides, an $\mathrm{MC}$ was favored in high-Ti and low-temperature $\left(650^{\circ} \mathrm{C}\right)$ aged samples [16]. The $\mathrm{M}_{2} \mathrm{C}$-type carbides had more deleterious effects on Hastelloy $\mathrm{N}$ ductility than the MC type. MCs precipitated on stacking faults also were detrimental to material ductility [16]. At elevated test temperatures $\left(1177\right.$ and $1260^{\circ} \mathrm{C}$ ), intergranular fracture was favored. Therefore, larger grain sizes (anneal temperature $1260^{\circ} \mathrm{C}$ ) produced low YS, and smaller grain sizes (at $1177^{\circ} \mathrm{C}$ ) produced low creep resistance [16]. As noted above, it is unclear what data were used to determine whether the precipitates were $\mathrm{MC}, \mathrm{M}_{2} \mathrm{C}, \mathrm{M}_{6} \mathrm{C}$, etc. Most of the microstructure images are at very low magnification and do not give any elemental information. It is unclear what method was used to determine the element ratios of the precipitates and where those data were reported. The detailed nature of the precipitates is often discussed in the MSRE-era literature, but the data about the precipitate compositions were not found. Although it helped improve the irradiation properties, Hastelloy $\mathrm{N}$ with $2 \% \mathrm{Ti}$ could not be used with the original salt chemistry used in the MSRE because the Te surface grain boundary cracking issue was as bad as in the base Hastelloy N [14]. Alternative element additions that improved both the irradiation properties and resisted the intergranular cracking were sought.

Hastelloy $\mathrm{N}$ modified with $\mathrm{Nb}$ was less developed than the $\mathrm{Ti}$-modified alloy as of the 1978 summary report, because it was developed only after the discovery of the Te embrittlement issue that occurred after significant development of the $\mathrm{Ti}$-modified alloy had already been completed [14]. Hastelloy $\mathrm{N}$ modified with $\mathrm{Nb}$ seemed adequate for welding, but this assumption was not extensively tested. The irradiated creep data on Hastelloy $\mathrm{N}$ with $\mathrm{Nb}$ show it performed well up to a $760^{\circ} \mathrm{C}$ irradiation temperature, at which point there was a sharp change and the behavior became worse. With more than $\sim 3.3 \% \mathrm{Nb}$, the modified Hastelloy $\mathrm{N}$ lost ductility [14]. The carbides in the Nb-modified alloy appear similar to those in the Ti-modified alloy, but not many details are available. Hastelloy $\mathrm{N}$ with $1-2 \% \mathrm{Nb}$ had some resistance to Te cracking but was not immune [14]. Also, there were some mixed results at the time, so further investigation was needed to see if the resistance was good enough [14]. A mechanism for $\mathrm{Nb}$ helping to prevent Te cracking was postulated but was unproved at the time. For Hastelloy $\mathrm{N}$ with simultaneous additions of both $\mathrm{Nb}$ and $\mathrm{Ti}$, the Te cracking was as bad as in standard Hastelloy $\mathrm{N}$, indicating that the Ti interfered with the benefit of the $\mathrm{Nb}$ addition [14]. Additionally, the Hastelloy $\mathrm{N}$ with $1 \%$ each of $\mathrm{Ti}$ and $\mathrm{Nb}$ was a complicated alloy and not fully understood. An important finding was that the reducing potential of the salt had an impact on Te cracking. If the salt were made sufficiently reducing, Hastelloy with Ti could be used and not undergo Te cracking [14]. Overall, the recommendations for structural materials were either Hastelloy $\mathrm{N}$ modified with $1-2 \% \mathrm{Nb}$ and the original salt chemistry, or Hastelloy $\mathrm{N}$ modified with $\mathrm{Ti}$ and with the salt in a reducing state [14]. Both of these operating material and salt conditions were projected to withstand both neutron damage and Te cracking adequately. 
The alloying elements $\mathrm{Zr}$ and $\mathrm{Hf}$ also were investigated and found to be good for forming the types of carbides that appeared to reduce the effects of neutron damage $[3,15]$. But these made Hastelloy $\mathrm{N}$ difficult to weld, so they were no longer added to alloys [14]. McCoy et al. thought that the irradiation resistance of Hastelloy $\mathrm{N}$ materials depended on $\mathrm{MC}$ formation, which occurs partly in processing but also during service at $500-650^{\circ} \mathrm{C}$. At higher temperatures, precipitates became too coarse, so they would not protect against irradiation damage [14]. If a higher service temperature were needed for an MSR, the whole precipitate formation and irradiation interaction would need to be experimentally tested and evaluated, or different alloys from Hastelloy $\mathrm{N}$-based materials would have to be used.

\subsubsection{Irradiated welds in base Hastelloy $N$}

Some of the surveillance samples included in the MSRE, exposed to salt and neutron irradiation simultaneously, were welded after removal from the MSRE to observe the influence of irradiation on weldability [17]. The material was the base Hastelloy used for construction of the MSRE.

Welds were made on the irradiated material using special equipment in the hot cells once the salt had been cleaned from them. As described in Ref. [17], "weld" appears to mean melting of about $75 \%$ of the 0.125 -in. diameter of a tensile specimen and letting it re-solidify without any addition of material, without cutting the material before melting, and without any attempt to join two pieces of metal together. The experiment survey was relatively small with 25 unirradiated and 15 irradiated samples tested. For tensile tests at $25^{\circ} \mathrm{C}$ in the as-welded case, the unirradiated and irradiated samples fractured in the base metal. After post-weld heat treatment of $8 \mathrm{~h}$ at $870^{\circ} \mathrm{C}$ and then tensile testing at $25^{\circ} \mathrm{C}$, both the unirradiated and irradiated samples fractured in the weld; this is thought to be because the heat treatment softened the welded area [17]. If the cause of brittle irradiated behavior is $\mathrm{He}$ at the grain boundaries, then welding should redistribute or release some $\mathrm{He}$ from the metal and make the HAZ from the weld softer than the unaffected regions of the sample [17]. For tensile tests at $650^{\circ} \mathrm{C}$ in the as-welded condition, both the unirradiated and irradiated samples fractured in the welded area. After post-weld heat treatment of $8 \mathrm{~h}$ at $870^{\circ} \mathrm{C}$ and tensile testing at $650^{\circ} \mathrm{C}$, the unirradiated material fractured in the welded area but the irradiated samples fractured in the base metal [17]. For the elevated tensile test case, both the base and welded area had some deformation; and the final fracture location was determined by the crack propagation. So it was postulated that cracks can more easily travel through the welded area in the unirradiated material, both as-welded and after the heat treatment. For the irradiated material, it was postulated that the cracks propagated more easily through the base metal [17]. Overall, they observed that for unirradiated material the TE strain at fracture decreased with increasing time at $650^{\circ} \mathrm{C}$; welding caused a reduction in TE for the unirradiated material compared with the base material; and as irradiation fluence increased, TE decreased. Some welds of the irradiated material were unsuccessful, showing that this technique requires some refinement; and overall more data should be collected to assess the effect of welding on irradiated Hastelloy $\mathrm{N}$ [17].

In a separate welding experiment, six different melts of nominal base composition Hastelloy $\mathrm{N}$ were used; four were air melted and two were vacuum melted, and all had slightly different composition and impurity levels [4]. A large, unirradiated plate of each material was cut in a precise way and then a TIG (tungsten inert gas) weld using select filler materials was used to join the two sections and fill the gap. This version of the base Hastelloy $\mathrm{N}$ had carbide stringers, which were generally perpendicular to the weld. Tensile samples were cut from the welded plates so that the tensile direction was perpendicular to the weld and then irradiated either at the ETR in Idaho or the ORR at ORNL [4]. Irradiations in the ETR were done with equal thermal and fast (>1 MeV) fluxes of neutrons, each $3.2 \times 10^{14} \mathrm{n} /\left(\mathrm{cm}^{2} \mathrm{~s}\right)$, to a total fluence of $5 \times 10^{14} \mathrm{n} / \mathrm{cm}^{2}$ at temperatures of 
less than $\sim 150^{\circ} \mathrm{C}$ and $\sim 600^{\circ} \mathrm{C}$ [4]. Irradiations in the ORR were conducted with a thermal neutron flux of $2.5 \times 10^{14} \mathrm{n} /\left(\mathrm{cm}^{2} / \mathrm{s}\right)$, to a total thermal fluence of $8.5 \times 10^{20} \mathrm{n} / \mathrm{cm}^{2}$ and a total fast $(>1 \mathrm{MeV})$ fluence of $7.0 \times 10^{20} \mathrm{n} / \mathrm{cm}^{2}$ at $\sim 43^{\circ} \mathrm{C}$. The authors did not consider the effects of the different neutron energy spectra, differences in flux, or differences in fluence between the two reactors; the results are only discussed in terms of the different irradiation temperatures [4]. If, as the MSRE era authors postulate, much of the mechanical property degradation after irradiation is because of transmutation and He generation, the neutron energy spectrum may indeed influence the final results. Unirradiated and irradiated metals from the six melted batches were tensile tested and creep tested. The unirradiated base metal had on the order of $\sim 60 \% \mathrm{TE}$ at RT; but after irradiation, the TE of the base metal was $~ 35 \%$ [4]. The unirradiated base metal had a complicated pattern of TE change with increasing test temperature, whereas the irradiated base metal generally had decreasing TE with increasing test temperature [4]. Both the unirradiated and irradiated welds were similar in having $\sim 20 \%$ TE at RT, then decreasing to $\sim 10 \%$ TE at $\sim 870^{\circ} \mathrm{C}$ test temperature, and then returning to over $20 \% \mathrm{TE}$ at $\sim 980^{\circ} \mathrm{C}$ [4]. The irradiated welds and irradiated base metal had similar TE values. The unirradiated welds had higher $Y S$ than unirradiated base metal, and the $Y S$ of the unirradiated welds and the base metal decreased with increasing test temperature. The irradiated base metal had a higher YS at RT than the unirradiated base or weld metal, but this decreased faster with test temperature; thus, they all had similar values around $650^{\circ} \mathrm{C}$ test temperature [4]. The change in TE is more important and significant than the change in $\mathrm{YS}$ or UTS. Several heat treatments were applied to the unirradiated and irradiated welded material, and the tensile results for the air-melted and vacuum-melted materials were also compared [4]. Creep measurements showed the welds had worse creep properties than the base metal in the unirradiated condition. Irradiation caused the base metal to have a much lower creep-rupture strength than the unirradiated metal [4]. However, the creep rate was not changed much by irradiation or welding. Post-weld heat treatments at 650,760 , and $870^{\circ} \mathrm{C}$ and for varying times were conducted, with $8-\mathrm{h}$ treatment at $870^{\circ} \mathrm{C}$ preferred. Different durations of heat treatment at $870^{\circ} \mathrm{C}$ resulted in poor results but the mechanism was unknown [4]; these results illustrate the complicated thermal aging behavior of Hastelloy $\mathrm{N}$.

Metallography showed a change in the carbide structure from the $\mathrm{M}_{6} \mathrm{C}$ type in the base metal to a lamellar phase, postulated to be a Mo-Ni-Si compound, in the heated zone of the weld [4]. The imaging was generally conducted at $100 \times$ or $500 \times$ magnification with no scale bars used. The actual sizes of the features in the images can be estimated by measuring the size of the image in the report; but there are large uncertainties regarding whether the image was resized after being made, or when the report was scanned and how the digital file is shown on the computer. Despite these limitations, we can estimate that features on the order of 10s-100s of $\mu \mathrm{m}$ in size are seen in the images. Typical SEMs today can easily magnify a surface to $50,000 \times$ magnification, which allows the examination of features on the order of $100 \mathrm{~nm}$ or smaller. Today, irradiation damage is typically examined in TEMs that can easily see features of the size of $10 \mathrm{~nm}$, and it is possible to see much smaller features, down to atoms. Such small-scale analysis allows typical radiationinduced defects - for example, loops or voids that are $5 \mathrm{~nm}$ in diameter - to be visualized. This is not to say that the $10 \mathrm{~s}-100 \mathrm{~s}$ of $\mu \mathrm{m}$ features seen at the time of the MSRE are unimportant for the behavior of the material; but these facts illustrate that there may be much more happening in the material that could be seen today but could not be examined at the time.

To summarize the irradiated welding experiments, all the welds had properties inferior to those of the base metal in Hastelloy $\mathrm{N}$, and the welds affected the strain more than the strength [4]. Also, there were reductions in the high-temperature creep-rupture strength. Of the melts tested, in the as-welded condition, the vacuum-melted welds had superior creep-rupture properties compared with the air-melted welds. Neutron irradiation caused the TE of the base metal and welded metal 
to decrease compared with unirradiated values; and as test temperature increased, the welded and base metal irradiated TEs were more similar. Post-weld annealing did not have a large influence on the post-irradiation fracture strains of the welds [4]. In general, the report has little discussion of the mechanisms governing the observed behavior of the mechanical properties of the welds, irradiated material, and heat treatments.

\subsubsection{Ion irradiation studies of Hastelloy $N$}

Several recent studies (2014-2017) have focused on the ion-irradiated properties of Hastelloy N [18-21]. These experiments use modern high-resolution TEM to investigate the microstructure of Hastelloy $\mathrm{N}$ after ion irradiation. This level of microstructure analysis was unavailable at the time of the MSRE. However, ion irradiation can cause different defect structures than neutron irradiation, so the results of the ion irradiation studies may not be generally applicable to the behavior of Hastelloy $\mathrm{N}$ under irradiation.

The primary degradation pathways in Ni-based alloys involve radiation-induced swelling and embrittlement [18]. Xenon (Xe) ion irradiation of Hastelloy-N showed that radiation-induced defects such as black dot defects and dislocation loops are formed in the materials, especially at $>1 \mathrm{dpa}$. Volumetric swelling and lattice expansion, possibly due to the formation of vacancy and interstitial defects as a result of heavy ion irradiation into an incompressible solid, were also reported [18]. Material hardening as a result of interactions of radiation-induced defects with line dislocations were also observed in Hastelloy-N alloy after ion irradiation. With an increase in dose, the defect size increased and the defect number density decreased [18].

It was shown that the hardness of Hastelloy- $\mathrm{N}$ increased after $\mathrm{Xe}^{+}$ion irradiation and was greatest for the samples irradiated using a low dose rate [19]. At the same total dose of irradiation, the size and number density of radiation-induced defects in Hastelloy $\mathrm{N}$ were greater for a lower dose rate than a higher dose rate. Radiation hardening was greater for larger sizes and higher number densities of defects in samples. Vacancy-type defects were also reported in the material with increases in the dose [19]. Vacancies and interstitials formed as a result of displacement of atoms in the crystal lattice by heavy $\mathrm{Xe}^{+}$ions. These vacancies and interstitials and their movements dislocation loops, and radiation-induced precipitates acted as dislocation glide barriers, resulting in slip stresses and therefore causing radiation hardening in Hastelloy $N$ [19].

Room-temperature $\mathrm{Ar}^{+}$ion irradiation of Hastelloy $\mathrm{N}$ showed the formation of (black or Frank loops) dot-type defects starting at $0.4 \mathrm{dpa}$ and growth in their size with increased irradiation up to 2 dpa [20]. Nanoscale dislocation loops were observed at 4 dpa. At higher dpa (e.g., 4 dpa), the Frank loops were absorbed by loops becoming apparent at these irradiation levels. Interstitial loops were preferentially prominent compared with vacancy loops because of their growthabsorbing interstitial atoms [20]. More radiation-induced defects, including line dislocations, were observed at $12 \mathrm{dpa}$. While dislocation loop sizes increased (30-80 nm) at $40 \mathrm{dpa}$, an fcc nanocrystalline phase was reported [20].

Helium-ion-implanted $\left(30 \mathrm{keV}, 5 \times 10^{16}\right.$ ions $\left./ \mathrm{cm}^{2}\right)$ Hastelloy $\mathrm{N}$ was shown to contain He bubbles [21]. After thermal annealing at $850^{\circ} \mathrm{C}$, Mo was diffused into the near-surface region of Hastelloy $\mathrm{N}$, and larger bubbles were observed in Mo-enriched regions than in Mo-low bulk sample areas deeper from the surface. Thermal annealing also released a significant amount of He bubbles, mostly from the grain boundaries with some from the bulk surface, reducing its concentration in the material [21]. 


\subsubsection{Conclu ding remarks and gap analysis}

The MSRE, 1965-69, showed that Hastelloy N embrittles at elevated temperatures and undergoes intergranular surface cracking when exposed to thermal neutrons and fuel salt containing fission products, respectively [22]. Ductility could be improved by modifying Hastelloy $\mathrm{N}$ with $2 \% \mathrm{Ti}$, but this alloy had the same level of intergranular surface cracking as the original Hastelloy $\mathrm{N}$. The intergranular surface cracking was a result of the attack of Te, Se, and $\mathrm{S}$, fission products of irradiated fuel salt [22]. Hastelloy $\mathrm{N}$ containing $\sim 1 \% \mathrm{Nb}$ showed good resistance to $\mathrm{Te}$ attack with adequate resistance to thermal-neutron embrittlement at temperatures up to $650^{\circ} \mathrm{C}$ [22]. However, Hastelloy $\mathrm{N}$ modified with $\mathrm{Nb}$ was discovered late in the MSRE project, so little irradiation testing was performed on that alloy. The evolution of the Hastelloy $\mathrm{N}$ alloys through the MSRE project is shown in Table 18. The carbon content is also important as the carbides are critical to the material behavior. The typical amount of carbon was $0.05 \%[4,9]$, with a maximum allowable range of $0.04-0.08 \%$ [3]. Careful control of the $\mathrm{U}^{3+} / \mathrm{U}^{4+}$ ratio can be another solution for lessening intergranular attack on Hastelloy- $\mathrm{N}$ [22].

Table 18 Compositions of Hastelloy $\mathbf{N}$ through the MSRE project from Ref. [22] in weight percent. Fe and Mn were considered less important, so their quantities might change in future batches. Where single values are given, it is considered the maximum allowable amount [22]

\begin{tabular}{|lcccccc|ccccc|}
\multicolumn{1}{|c}{ Alloy } & $\mathbf{N i}$ & $\mathbf{F e}$ & $\mathbf{C r}$ & $\mathbf{M o}$ & $\mathbf{M n}$ & $\mathbf{S i}$ & $\mathbf{N b}$ & $\mathbf{T i}$ & $\mathbf{P}$ & $\mathbf{S}$ & $\mathbf{B}$ \\
\hline Standard & $67-72$ & 5 & $6-8$ & $15-18$ & 1 & 1 & - & - & 0.015 & 0.020 & 0.01 \\
$\begin{array}{l}\text { Modified } \\
1972\end{array}$ & $74-81$ & 0.1 & $6-8$ & $11-13$ & $0.15-0.25$ & 0.1 & $0-2$ & 2 & 0.01 & 0.01 & 0.001 \\
$\begin{array}{l}\text { Modified } \\
1976\end{array}$ & $76-83$ & 0.1 & $6-8$ & $11-13$ & $0.15-0.25$ & 0.1 & $1-2$ & - & 0.01 & 0.01 & 0.001 \\
\hline
\end{tabular}

Hastelloy $\mathrm{N}$ has been approved for certain non-nuclear applications in ASME code cases 1315 and 1345 at temperatures up to $704^{\circ} \mathrm{C}$ [23]. More materials property data are needed before ASME would consider it for the class of components used in nuclear fields at high temperatures. Ren et al. in 2011 surveyed selected data on Hastelloy N from the MSRE time and beyond and determined that Hastelloy $\mathrm{N}$ modified with $\mathrm{Nb}$ was the leading candidate for an FHTR, but the alloy needed further improvements before it could be used in a reactor [23]. It needs a higher maximum use temperature and better high-temperature strength and corrosion resistance [23]. The 2017 article by Allen et al. also considered Hastelloy $\mathrm{N}$ modified with $\mathrm{Ti}$ or $\mathrm{Nb}$ to be the best candidate Ni-based alloy for molten fluoride salts at temperatures below $\sim 750^{\circ} \mathrm{C}$ [24], although their analysis focused more on the corrosion properties than the irradiation behavior of the materials they considered.

Table 19 is a summary of some of the types of data available for neutron-irradiated Hastelloy N. Although it is not exhaustive, it lists many properties that are needed for understanding the evolution of the material under neutron irradiation and creating design rules for a reactor component. A qualitative rating between 1 (no data) and 4 (complete data) was given for each property, considering both the quantity of data available and the quality of those data. The assignment of rank 1 to 4 for each of these properties was not a strict and rigorous ranking process but was intended as a simplified visual representation of the gaps. In this process, all 
properties of neutron-irradiated Hastelloy $\mathrm{N}$ were given a rank of 1 or 2 , indicating either no data exist or very limited data exist. It was concluded that no property has enough data of high enough quality to be considered to be at level 3 (moderate amount of information) or 4 (complete database for relevant operating and off-normal conditions).

Table 19 Summary of data available for neutron -irradiated Hastelloy $\mathbf{N}$.

\begin{tabular}{|c|c|c|c|}
\hline Property & $\begin{array}{l}\text { Data } \\
\text { score }\end{array}$ & Note & Selected reference(s) \\
\hline \multicolumn{4}{|l|}{ Thermal properties } \\
\hline Thermal conductivity & 1 & Was not measured & \\
\hline Thermal expansion & 1 & Was not measured & \\
\hline Thermal ageing & 2 & $\begin{array}{l}\text { Some experiments done, but } \\
\text { lacking microstructure } \\
\text { information so may not be useful }\end{array}$ & {$[5,7]$} \\
\hline \multicolumn{4}{|l|}{ Physical properties } \\
\hline Swelling & 1 & $\begin{array}{l}\text { Was not measured, was not } \\
\text { discovered at time of MSRE }\end{array}$ & \\
\hline Thermal creep & 2 & & {$[7,8]$} \\
\hline Irradiation creep & 1 & $\begin{array}{l}\text { Was not measured, was not } \\
\text { discovered at time of MSRE }\end{array}$ & \\
\hline \multicolumn{4}{|l|}{ Mechanical properties } \\
\hline Tensile strength & 2 & $\begin{array}{l}\text { Some conditions tested, large } \\
\text { variety of alloy versions }\end{array}$ & {$[6,7]$} \\
\hline Fracture toughness & 1 & Was not measured & \\
\hline Hardness & 1 & Was not measured & \\
\hline Bend strength & 1 & Was not measured & \\
\hline \multicolumn{4}{|c|}{ Microstructural information } \\
\hline $\begin{array}{l}\text { Precipitate } \\
\text { size/distribution }\end{array}$ & 2 & $\begin{array}{l}\text { Many things postulated without } \\
\text { data, needs to be measured with } \\
\text { modern methods }\end{array}$ & {$[5,8]$} \\
\hline Void & 1 & No analysis found & \\
\hline Bubble/cavity & 2 & $\begin{array}{l}\text { A few images exist, does not } \\
\text { constitute thorough } \\
\text { measurement or understanding }\end{array}$ & [8] \\
\hline $\begin{array}{l}\text { Grain sizes and } \\
\text { crystallographic texture }\end{array}$ & 1 & Was not measured & \\
\hline Irradiation defects & 1 & Was not measured & \\
\hline
\end{tabular}


Table 19 Summary of data available for neutron -irradiated Hastelloy $\mathbf{N}$ (continued).

\begin{tabular}{|c|c|c|}
\hline Property & $\begin{array}{l}\text { Data } \\
\text { score }\end{array}$ & Selected reference(s) \\
\hline \multicolumn{3}{|l|}{ Elemental information } \\
\hline Transmutation elements & 1 & $\begin{array}{l}\text { Amount of transmutation was } \\
\text { not calculated or measured }\end{array}$ \\
\hline He appm & 1 & Was not measured \\
\hline Segregation & 1 & $\begin{array}{l}\text { No data taken regarding } \\
\text { radiation-induced segregation }\end{array}$ \\
\hline $\begin{array}{l}\text { Precipitate } \\
\text { composition/phase }\end{array}$ & 1 & $\begin{array}{l}\text { Many things postulated without } \\
\text { data, needs to be measured with } \\
\text { modern methods }\end{array}$ \\
\hline
\end{tabular}

$=$ No information

2 =Limited information

$3=$ Moderate amount of information

4 =Complete database for relevant operating and off-normal conditions

\section{Summary of the data that exist for Hastelloy $\mathrm{N}$ and modified Hastelloy $\mathrm{N}$}

One source of materials data was from material irradiated in the MSRE. From these experiments several types of data were collected: tensile data on irradiated materials, often from RT and the irradiation temperature; thermal creep data on irradiated materials; tensile data on material that was welded after irradiation in the MSRE; a few TEM images of irradiated material microstructure; many SEM or optical images of irradiated surfaces and cross sections at low magnification (usually $500 \times$ magnification or less).

There are several limitations of the data from test coupons in the MSRE. While the irradiation data from the materials in the MSRE are valuable because they represent the combined irradiation, stress, and chemistry of a reactor, there is also an associated limitation to this complexity. The MSRE was itself an experiment, so had some variations in temperature, neutron fluence, and other conditions during its operation. Therefore, the materials irradiated in the MSRE were often exposed to a complicated and difficult-to-replicate set of conditions. Hastelloy $\mathrm{N}$ was being actively developed during the course of the MSRE, so many different versions of Hastelloy $\mathrm{N}$ were irradiated, including different production methods, different heat treatments, and different alloying elements. There is not a comprehensive large data set for the properties of one specific alloy composition that received an optimized production method and pre-irradiation heat treatment.

The other source of neutron irradiation data was from materials irradiated in ETR or ORR during the MSRE project. This captures the data based on the references summarized previous in this section; not necessarily an exhaustive list of all irradiations during the MSRE era. In two different experiments in the ORR, versions of base Hastelloy $\mathrm{N}$ were irradiated to two similar neutron fluences and irradiation temperatures of 650,700 , and $760^{\circ} \mathrm{C}$; tensile data were collected at temperatures up to $800^{\circ} \mathrm{C}$. In two experiments in the ORR and one in the ETR, versions of base Hastelloy $\mathrm{N}$ were irradiated to three similar neutron fluences and irradiation temperatures of $\sim 40$, $150,600,650,700$, and $760^{\circ} \mathrm{C}$; thermal creep data were generally collected at 650 and $760^{\circ} \mathrm{C}$. A few additional test reactor experiments were conducted on Hastelloy $\mathrm{N}$ with alloying modifications and on welded base Hastelloy N. Tensile and thermal creep properties were measured on 
selected samples. Some SEM and optical surface images were taken of irradiated materials. Some TEM images were taken of irradiated microstructure features.

There are limitations of the test reactor experiments. The reactor irradiations were conducted on many different versions of Hastelloy $\mathrm{N}$ and modified Hastelloy $\mathrm{N}$; they differed in terms of alloy composition, heat treatment, production method, impurity content, and other factors. The irradiations summarized in this report all used different varieties of Hastelloy N. Hastelloy $\mathrm{N}$ modified with $\mathrm{Nb}$ is generally considered the frontrunner of the Hastelloy $\mathrm{N}$ versions tested during the MSRE era. However, this alloy was discovered and tested only late in the MSRE project, so few data were collected for it. It is unclear how the fluences and energy spectrums of the test reactors compare with the conditions in the MSRE or what would be expected in a reactor lifetime.

In addition to the neutron irradiation studies, there have been some ion irradiation studies of Hastelloy N. These studies used modern, high-resolution TEM and collected hardness data. While modern TEM for examining the microstructure may be very useful for understanding irradiation damage in Hastelloy $\mathrm{N}$, these results must carefully be compared with its behavior under neutron irradiation. It is unclear whether any neutron-irradiated microstructure evaluation has been done for comparison with the ion-irradiated cases. Ion irradiation affects only a small volume, so the types of mechanical tests that are useful for engineering purposes (e.g., tensile and creep) cannot typically be done with ion-irradiated materials.

\section{General limitations of existing data and knowledge gaps for Hastelloy N}

1. Gap: changing alloy compositions

Throughout the MSRE, the composition and production method of Hastelloy $\mathrm{N}$ changed, so there is not a long irradiation history of one unique alloy produced in a particular way.

2. Gap: limited mechanical property behavior

The MSRE era data focused on tensile and thermal creep. However, these types of data, in addition to many other thermal, physical, and mechanical data would be needed for designing a nuclear reactor today.

o Swelling was discovered only in 1967 and so was not considered during the MSRE project. Whether swelling is a concern for Hastelloy $\mathrm{N}$ depends on the neutron energy spectrum and total fluence expected in a reactor. The swelling behavior of Hastelloy $\mathrm{N}$ needs to be measured.

- Thermal creep (elevated temperature plus stress causing a dimensional change) was measured; but irradiation-induced creep (irradiation plus stress causing a dimensional change) was discovered later than swelling and so was not considered during the MSRE project. Irradiation creep need to be measured and evaluated before Hastelloy $\mathrm{N}$ can be used in a reactor.

o Other mechanical properties may need to be measured, such as tensile strength, thermal creep, fracture toughness, and hardness. 
- Thermal properties will need to be measured, such as CTE and thermal conductivity.

- Gas permeability for fission products and tritium may need to be measured.

3. Gap: precipitation and phase stability

Some work was completed on aging behavior of Hastelloy $\mathrm{N}$, but understanding of the precipitation and phase stability over long service periods with irradiation is lacking. The behavior of the carbides, in particular, is one of two factors cited by MSRE researchers as determining the irradiation behavior of the alloy. Understanding carbide behavior is critical to understanding and predicting Hastelloy $\mathrm{N}$ behavior under irradiation.

4. Gap: unknown mechanisms of degradation

Many of the historical reports postulated mechanisms without being able to prove them at the time.

- The relationship between He generation and irradiation embrittlement. It is a fact that ${ }^{10} \mathrm{~B}$ and several $\mathrm{Ni}$ isotopes transmute and release $\mathrm{He}$ into the material. Some TEM images from the MSRE reports show small cavities after irradiation, which were assumed to be He bubbles. Work to optimize the alloy often centered on adjusting the composition to trap the $\mathrm{B}$ in precipitates. Then theories were presented regarding their success that were based on macroscopic measures such as creep data. What is missing is experimental observation of the before-and-after-irradiation microstructure to support the theories from the MSRE era regarding where He migrated after irradiation and the effect of changing alloy composition on He behavior. As discussed further in the section Other Nickel Alloys, the embrittlement of Ni-based alloys may be caused by several factors, including phase transformations and He behavior. More experimental evidence is needed to understand which factors are most important in Hastelloy N.

o The evolution of precipitates, phases, and carbides with time, temperature, and irradiation. In the MSRE reports, the specific nature of the precipitates in Hastelloy $\mathrm{N}$ after a specific treatment (for example, whether they are $M_{6} C$ precipitates or $M_{23} C$ precipitates) is often stated. It is unclear whether the data used to determine the nature of the precipitates was published elsewhere from the reports cited here, but the data did not seem to be present in the references that were reviewed. It is also possible that the MSRE researchers were making educated guesses about the precipitate nature based on their familiarity with the alloy, careful examination of phase diagrams, or other circumstantial evidence. In either case, because the precipitates are key to the behavior of Hastelloy $\mathrm{N}$, the nature of the precipitates should be verified with modern microscopy techniques.

5. Gap: existing neutron irradiated microscopy data is poor quality

- Low magnification. Most of the optical or SEM images are taken at 500× magnification or lower. This level of magnification allows the identification of features on the order of a few 10 s up to a few 100 s of $\mu \mathrm{m}$. This is an appropriate magnification to examine macroscopic features such as grain boundary cracks and certain precipitates, but many smaller-scale features might be important to the behavior but not imageable at the time of the MSRE. Examples are seen in Figure 33, Figure 34, and Figure 38. 
- Generally no scale bars. Most commonly, the sizes of images are indicated by the degree of magnification. This is insufficient to uniquely identify the sizes of features in the images, because it is unknown if the images were resized anywhere along their path from the instrument, to the original report, to the scanned photocopy of the report, to the digital copy of the report that is currently available. Examples are seen in Figure 33, Figure 34, and Figure 37.

- Low-quality images. Many images have low dynamic range, meaning only a few similar grey shades are used for binning the data; or they have high contrast but very few shades are used-for instance, a true black and white is used instead of a grayscale image. The images generally have low data content (large pixels), which may be attributed to limitations of the instruments at the time plus data loss during repeated photocopying of the reports before they were stored in their current digital form. These factors make it difficult to gather useful information from some of the images. Examples are seen in Figure 34, Figure 35, and Figure 39.

o Inability to match text descriptions to features in the images. A combination of low image quality and time limitations prevented researchers from placing indicator marks like arrows on the figures, so it is difficult in some cases to identify features in the images that the authors describe in the text as important. An example is seen in Figure 34.

- Lack of statistics. It does not appear that any statistics about the microstructural features were collected in any of the reports reviewed. For example, a histogram of grain or precipitate size distributions to quantitatively compare the material after different heat treatments would be useful, but this type of information was not collected at the time of the MSRE. An example is seen in Figure 36: a TEM image of one precipitate and several cavities was presented in a report, but there is no accompanying calculation of the cavity or precipitate size distribution or number density.

6. Opportunities for improvement

Although the data collected so far on Hastelloy $\mathrm{N}$ are piecemeal, they indicate that further optimization of the alloy may be needed for it to perform successfully in a reactor. Once more data are collected and the degradation mechanisms are understood, the alloy can be further improved.

- Alloy compositional optimization can be completed and modern thermodynamics modeling can be used to streamline the process.

- Adding additional defect sinks such as oxide particles may be considered.

- Methods such as grain boundary engineering (GBE) have generally been successful with Ni-based alloys, so GBE may be considered for Hastelloy $\mathrm{N}$ to improve its radiation resistance. Additionally, since grain boundary cracking was a critical issue for Hastelloy N, the effect of GBE on the strength of the grain boundaries could be tested to see if it makes them more resistant to cracking. 


\subsection{Alloys Based on Hastelloy N}

\subsubsection{Summary of previous work}

The Kurchatov Institute in Russia developed alloys based on Hastelloy N (Table 20) with the goals of improving their irradiation resistance and Te cracking resistance and increasing the use temperature to $800^{\circ} \mathrm{C}$ [25]. HN80MT was the first alloy they produced; 70 different modified version of it were produced, including the alloying elements $\mathrm{W}, \mathrm{Nb}, \mathrm{Re}, \mathrm{V}, \mathrm{Al}, \mathrm{Mn}$, and $\mathrm{Cu}$. Corrosion test results narrowed the modified alloys to 13 selections that were neutron irradiated to $3 \times 10^{20} \mathrm{n} / \mathrm{cm}^{2}$. The specific neutron irradiation results were not cited by lgnatiev et al. The alloy with the best performance in the neutron irradiation tests according to Ignatiev et al. was named HN80MTY (or EK-50); HN80MTY also had reduced intergranular cracking compared with HN80MT [25]. Further refinement of the Hastelloy $\mathrm{N}$-based alloys was done to develop the related alloys $\mathrm{HN} 80 \mathrm{M}-\mathrm{VI}$, which contains $1.5 \% \mathrm{Nb}$; HN80MTY with $1 \% \mathrm{Al}$; and MONICR with $2 \%$ Fe. In another group of corrosion experiments by Ignatiev et al., several alloy systems were tested and the Ni-based HN80MTY alloy (Mo-13, Cr-6.8, Al-1.1, Ti-0.9 wt \%) showed the best resistance [26]. A recent study from 2017 further compared the corrosion of HN80MT and HN80MTY and found that HN80MTY performed better [27].

Table 20 Alloy compositions (mass \%) of Hastelloy $\mathbf{N}$ family and Kurchatov Institute developed alloys . From Ref. [25]

\begin{tabular}{|c|c|c|c|c|c|c|c|}
\hline Element & Hastelloy-N (INOR-8) & Hastelloy-N Ti-mod. & Hastelloy-N Nb-mod. & MONICR & HN80M-VI & HN80MTY (EK-50) & HN80MT \\
\hline $\mathrm{Ni}$ & Base & Base & Base & Base & Base & Base & Base \\
\hline $\mathrm{Cr}$ & 7.52 & $6-8$ & $6-8$ & 6.85 & 7.61 & 6.81 & 7.02 \\
\hline Mo & 16.28 & $11-13$ & $11-13$ & 15.8 & 12.2 & 13.2 & 12.1 \\
\hline $\mathrm{Ti}$ & 0.26 & 2 & - & 0.026 & 0.001 & 0.93 & 1.72 \\
\hline $\mathrm{Fe}$ & 3.97 & 0.1 & 0.1 & 2.27 & 0.28 & 0.15 & $<0.33$ \\
\hline $\mathrm{Mn}$ & 0.52 & $0.15-0.25$ & $0.15-0.25$ & 0.037 & 0.22 & 0.013 & $<0.1$ \\
\hline $\mathrm{Nb}$ & - & $0-2$ & $1-2$ & $<0.01$ & 1.48 & 0.01 & - \\
\hline $\mathrm{Si}$ & 0.5 & 0.1 & 0.1 & 0.13 & 0.040 & 0.040 & $<0.05$ \\
\hline $\mathrm{Al}$ & 0.26 & - & - & 0.02 & 0.038 & 1.12 & - \\
\hline W & 0.06 & - & - & 0.16 & 0.21 & 0.072 & - \\
\hline $\mathrm{Cu}$ & 0.02 & - & - & 0.016 & 0.12 & 0.020 & $<0.01$ \\
\hline Co & 0.07 & - & - & 0.03 & 0.003 & 0.003 & - \\
\hline $\mathrm{Ce}$ & - & - & - & $<0.003$ & 0.003 & 0.003 & - \\
\hline $\mathrm{Zr}$ & - & - & - & 0.075 & - & - & - \\
\hline B & $<0.01$ & 0.001 & 0.001 & $<0.003$ & 0.008 & 0.003 & $<0.001$ \\
\hline$S$ & 0.004 & 0.01 & 0.01 & 0.003 & 0.002 & 0.001 & $<0.001$ \\
\hline $\mathrm{P}$ & 0.007 & 0.01 & 0.01 & 0.003 & 0.002 & 0.002 & $<0.001$ \\
\hline C & 0,05 & 0.05 & 0.05 & 0.014 & 0.02 & 0.025 & 0.004 \\
\hline
\end{tabular}

- The elements were neither added to the melt nor determined.

The Kurchatov Institute experiments appear to focus on corrosion behavior, and little or no information is available on the alloys after exposure to neutron irradiation. Additionally, a lack of knowledge of neutron irradiation effects is clear from several statements in the article. Ignatiev et al. state that the MSRE team created modified Hastelloy $\mathrm{N}$ with finer precipitates to prevent $\mathrm{He}$ from going to the grain boundaries [25]. This statement is partially true-the MSRE team did work to create Hastelloy N-based alloys with finer carbides, and the MSRE reports often speculated that $\mathrm{He}$ was the cause of the embrittlement of Hastelloy $\mathrm{N}$ after irradiation. However, the MSRE team was unable to directly measure the effect of the carbides on the He at the time of its work. Also, Ignatiev et al. mistakenly state "...it is desirable to design MSRs in which the exposure of the reactor vessel wall to fast neutron radiation is limited" [25]. In fact, it is thermal neutrons that cause ${ }^{10} \mathrm{~B}$ to transmute and release a He atom, so exposing the reactor vessel to fewer fast neutrons (and more thermal neutrons) would have the opposite effect and increase the He generation. 


\subsubsection{Conclu ding remarks and gap analysis}

For the Russian alloys MONICR, HN80M-VI, HN80MTY, and HN80MT, the references cited obliquely mention neutron irradiation data but do not cite any papers containing the neutron irradiation data. It is unclear how much irradiation testing has been completed on those alloys, but likely very little has been done. No judgement can be made yet regarding the performance of these alloys in a nuclear environment. Data need to be collected on the thermal, physical, and mechanical properties, along with microstructural and elemental information for these alloys after neutron irradiation to determine if they would be suitable for use in an MSR.

\subsection{Other Nickel -based Alloys}

Nickel-based alloys are considered for many applications that involve high-temperature service or exposure to molten salts. Generally, Ni-based alloys have better creep strength than austenitic and ferritic martensitic steels, which is why they are often the choice for high-temperature applications, $>600^{\circ} \mathrm{C}$ [28]. Also, $\mathrm{Ni}$ is relatively stable in MSR salts, which is why mainly Ni-based alloys are considered [24]. Hastelloy $\mathrm{N}$ is the Ni alloy for MSRs about which the most has been written. But many other Ni-based alloys have also received varying amounts of irradiation and corrosion testing that may be useful for MSRs. The irradiation behavior of some of these other Nibased alloys is summarized here.

For any material, the conversion from neutron fluence to dpa must consider the energy spectrum of the neutrons in the particular reactor environment where they were irradiated; different nuclear reactors or test reactors will have different conversions between fluence and dpa for the same material. As a first approximation for converting fluence to dpa for Ni-based alloys, two conversions for Fe alloys are suggested: the NRT and the N/2 with a conversion of $1 \times 10^{26} \mathrm{n} / \mathrm{m}^{2}$ $(E>0.1 \mathrm{MeV})=5 \mathrm{dpa}$ NRT, $(\mathrm{Fe})=6.25 \mathrm{dpa}(\mathrm{N} / 2)$ [29]. Some Ni-based alloys considered for nuclear applications are listed in Table 21. For all Ni-based alloys, neutron irradiation concerns include void swelling, irradiation creep, microstructure stability, and irradiation embrittlement [29].

Table 21 Nominal nickel -based alloy compositions in wt \% .

\begin{tabular}{|c|c|c|c|c|c|c|c|c|c|c|c|c|c|}
\hline Alloy & $\mathbf{N i}$ & $\mathrm{Fe}$ & $\mathrm{Cr}$ & Mo & Nb & Co & $w$ & Ti & Al & Mn & Si & $\mathrm{Cu}$ & C \\
\hline $\mathrm{D} 21^{\mathrm{b}}$ & 25 & 58.6 & 8.4 & 1 & - & - & - & 3.3 & 1.7 & 1 & 1 & - & 0.04 \\
\hline $\mathrm{D} 25^{\mathrm{b}}$ & 30 & 50.7 & 10.5 & 3.7 & - & - & - & 1.8 & 1.3 & 1 & 1 & - & 0.04 \\
\hline $800 \mathrm{H}^{a}$ & 33 & 45 & 21 & - & - & - & - & 0.4 & 0.4 & - & - & - & 0.08 \\
\hline $\begin{array}{c}\text { Incoloy } \\
800^{\mathrm{b}}\end{array}$ & 34 & 42.7 & 20.5 & - & - & - & - & 0.4 & 0.4 & 0.9 & 0.5 & 0.5 & 0.07 \\
\hline $\begin{array}{l}\text { PE16 } \\
\text { Matrix }^{b}\end{array}$ & 36 & 39.6 & 20 & 4 & - & - & - & - & - & 0.1 & 0.2 & - & 0.07 \\
\hline $120^{a}$ & 37 & 33 & 25 & - & 0.7 & 3.0 & - & - & 0.1 & - & - & - & 0.05 \\
\hline $\begin{array}{c}\text { Incoloy } \\
\text { DS }^{\mathrm{b}}\end{array}$ & 39 & 39.9 & 18 & - & - & - & - & 0.04 & 0.02 & 1 & 2 & - & 0.08 \\
\hline
\end{tabular}


Table 21 Nominal nickel -based alloy compositions in wt \% (continued)

\begin{tabular}{|c|c|c|c|c|c|c|c|c|c|c|c|c|c|}
\hline Alloy & $\mathrm{Ni}$ & $\mathrm{Fe}$ & $\mathrm{Cr}$ & Mo & $\mathrm{Nb}$ & Co & W & $\mathrm{Ti}$ & Al & Mn & Si & $\mathrm{Cu}$ & C \\
\hline $\begin{array}{l}\text { Alloy } \\
7817^{b}\end{array}$ & 40 & 38.2 & 15 & 3.2 & - & - & - & 2 & 0.9 & 0.2 & 0.5 & - & 0.02 \\
\hline $\begin{array}{l}\text { Alloy } \\
7818^{\text {b }}\end{array}$ & 40 & 38.0 & 15 & 3 & 3 & - & - & 0.3 & - & 0.2 & 0.5 & - & 0.02 \\
\hline $706^{a}$ & 42 & 37 & 16 & 0.1 & 2.9 & - & - & 1.7 & 0.3 & - & - & - & 0.03 \\
\hline PE16 ${ }^{a}$ & 43 & 33 & 17 & 3.7 & - & - & - & 1.2 & 1.3 & - & - & - & 0.05 \\
\hline $\begin{array}{l}\text { Nimonic } \\
\text { PE16 }\end{array}$ & 43 & 37 & 16.5 & 1.1 & - & - & - & 1.2 & 1.2 & 0.1 & 0.2 & - & 0.05 \\
\hline $617^{a}$ & 45 & 23 & 20 & - & - & 10.0 & - & 0.6 & 0.8 & - & - & - & 0.05 \\
\hline $617^{\circ}$ & 57.3 & 1.01 & 20.3 & 8.58 & - & 11.7 & - & - & 0.76 & 0.05 & 0.16 & - & 0.07 \\
\hline $\begin{array}{c}\text { Hastelloy } \\
X^{\mathrm{a}}\end{array}$ & 50 & 17 & 22 & 9.0 & - & 1.0 & 0.6 & - & - & - & - & - & 0.15 \\
\hline $\begin{array}{c}\text { Hastelloy } \\
X^{b}\end{array}$ & 48 & 18.4 & 21 & 9 & - & 2 & 0.5 & - & - & 0.5 & 0.5 & - & 0.1 \\
\hline $718^{b}$ & 52.5 & 18.5 & 19 & 3 & 5.2 & - & - & 0.9 & 0.5 & 0.2 & 0.2 & - & 0.04 \\
\hline $230^{a}$ & 55 & 3 & 22 & 2.0 & - & 4.0 & 14 & - & 0.3 & - & - & - & 0.10 \\
\hline $\begin{array}{c}\text { Inconel } \\
625^{\mathrm{b}}\end{array}$ & 61 & 3.5 & 22 & 9 & 3.5 & - & - & 0.3 & 0.3 & 0.2 & 0.2 & - & 0.05 \\
\hline $\begin{array}{c}\text { Inconel } \\
600^{\mathrm{b}}\end{array}$ & 75 & 7.7 & 16 & - & - & - & - & 0.3 & 0.2 & 0.2 & 0.2 & 0.3 & 0.08 \\
\hline
\end{tabular}

a Reported in Ref. [28]

${ }^{b}$ Reported in Ref. [29]

${ }^{\mathrm{c}}$ Reported in Ref. [30]

\subsubsection{Summary of previous work}

\section{General trends for Ni-based alloys}

For Ni-based alloys, there is a general pattern that increasing the Ni content decreases the swelling, but there are exceptions to this rule and the mechanism is still debated [29]. Ion irradiation results, in general, are difficult to compare with neutron irradiation results for Ni-based alloys; for one example, ion irradiation experiments typically do not capture the type of bulk phase changes that can occur during neutron irradiation. Also, ion irradiation predicts very low swelling for Hastelloy $X$, but neutron irradiation at $\sim 500-600^{\circ} \mathrm{C}$ resulted in very high swelling. Some heat treatments can reduce swelling [29]. Swelling requires excess vacancies, and typically for $\mathrm{Ni}$ alloys, these can occur in the irradiation temperature range of $\sim 350-700^{\circ} \mathrm{C}$ [29] which overlaps the typical temperature range for MSRs. Usually Ni diffuses slower than other alloying elements such as $\mathrm{Cr}$, so Ni becomes enriched at sinks such as void surfaces [29]. Silicon may help decrease swelling in some $\mathrm{Ni}$ alloys by diffusing faster and aiding recombination with vacancies 
[29]. Increasing the incubation dose before swelling can be accomplished by changing the microstructure to pin dislocations, creating sinks for point defects, and trapping He [28]. Irradiation creep has been studied more in austenitic SSs than in Ni alloys, but some of the same trends apply to both material types [29].

Helium transmutation in Ni alloys was identified early in their development as a concern. Many early reports, such as those from the MSRE era, postulated that He on the grain boundaries was the sole cause of irradiation embrittlement in the Ni alloy Hastelloy N. Although the theory of He weakening the grain boundaries was logical and plausible, it lacked clear before-and-after microstructural evidence and usually did not consider other causes of embrittlement [28]. The early reports' theory of embrittlement from He transmutation has been repeatedly cited by later works as if it were proven. More recent works have indeed been able to characterize He bubbles on grain boundaries in irradiated $\mathrm{Ni}$ alloys, but the debate continues about the relative contribution to embrittlement of He bubbles and other factors. There are several sources of $\mathrm{He}$ in $\mathrm{Ni}$ alloys under neutron irradiation, and their contribution depends on the neutron energy spectrum. With thermal neutrons, there is He production from the ${ }^{10} \mathrm{~B}(\mathrm{n}, \alpha)^{7}$ Li reaction and the two-step reaction ${ }^{58} \mathrm{Ni}(\mathrm{n}, \alpha){ }^{59} \mathrm{Ni}(\mathrm{n}, \alpha){ }^{56} \mathrm{Fe}$ [29]. If the thermal neutron fluence is high, the Ni reaction pathway will generate more He than B [29]. This may explain why MSRE researchers thought an extremely low level of B was needed to cause embrittlement; it could be instead that, for the alloys they fabricated with low B content, the transmutation of Ni was enough to nonetheless cause embrittlement. For fast neutron spectra, Ni also produces more He than other transmutation reaction, including $B$ [29]. Boothby calculated the He generation for PE16 in a fast neutron spectrum and found $85 \%$ of the He came from $\mathrm{Ni}$, and in total from all He-generating reactions, there was 1.2 appm He per dpa [29]. While the influence of He on embrittlement must be considered for $\mathrm{Ni}$ alloys, irradiation defects, grain boundary segregation, and precipitate changes can also contribute [29]. Although $\mathrm{He}$ is the most discussed by-product of the ${ }^{10} \mathrm{~B}$ reaction, ${ }^{7} \mathrm{Li}$ is also formed in the same reaction and some authors have examined its effect in Ni alloys [29].

Most of the Ni-based alloys discussed herein are precipitate hardened. The precipitate behavior under neutron irradiation is largely unknown [29]. Nickel-based alloys can have brittle phases form because of thermal aging or irradiation; and in fact, some phases that are not thermodynamically stable will form under irradiation [29].

\section{$\underline{\text { Nimonic PE16 }}$}

PE16 is less alloyed than either Inconel 706 or Inconel 718 [28]. The standard fabrication heat treatment causes distributed gamma prime precipitates (but not gamma double prime) [28]. At certain irradiation temperatures and conditions, these gamma prime precipitates coarsen [29]. PE16 has been tested at $280-340^{\circ} \mathrm{C}$ irradiation temperatures with a simultaneous load to test irradiation creep [29]. PE16 has also been tested at high dpa, including $116 \mathrm{dpa}$ at $538^{\circ} \mathrm{C}$ [29]. PE16 irradiated to $4.3 \times 10^{26} \mathrm{n} / \mathrm{m}^{2}$ and tensile tested at the irradiation temperature showed strengthening for $450-625^{\circ} \mathrm{C}$ but reduced strength at $735^{\circ} \mathrm{C}$ [29]. The TE had a minimum at around $550-650^{\circ} \mathrm{C}$ test temperature [29]. When these irradiated PE16 samples were tensile tested in situ with Auger analysis, He was measured upon fracture even though He bubbles were not observed with TEM [29]. Other neutron irradiation experiments on PE16 have observed He bubbles and/or cavities along grain boundaries [29]. The reason for the loss of ductility in PE16 under certain irradiation conditions is much debated. Some postulate that brittle fracture in PE16 occurs because of gamma prime forming on the grain boundaries, and that He effects are less important; others assert that the gamma prime phase is not always observed when there is a brittle failure, and that the He bubbles are the main cause of the embrittlement [29]. Several 
different studies have collected data on the neutron irradiation properties of this alloy, including those in Refs. [31-37]; those data are not summarized here.

\section{Inconel 706}

Inconel 706 has low swelling in the $400-600^{\circ} \mathrm{C}$ irradiation temperature range [28]. This alloy is more alloyed than PE16 and less alloyed than Inconel 718; both 706 and 718 are strengthened by the same types of precipitates. Inconel 706 loses ductility after irradiation but not as severely as Inconel 718 [28]. Gamma prime phase formation under irradiation may contribute to brittle behavior after neutron irradiation [29]. Additionally, eta phase development on the grain boundaries contributes to the loss of ductility [28]. TEM analysis of this alloy did not observe grain boundary He bubbles, so the behavior is believed to be controlled by the phase changes rather than by He bubbles on the grain boundaries [28].

\section{$\underline{\text { Inconel } 718}$}

Inconel 718 , or alloy 718 , is strengthened by gamma prime and gamma double prime phases, and heat treating controls their formation [28]. This alloy loses ductility after neutron irradiation, which is sensitive to the irradiation temperature. The loss of ductility is attributed primarily to gamma prime phase and eta phase platelets, not primarily to He bubbles [28]. Neither He bubble growth nor radiation-induced precipitation causes the embrittlement. Segregation of sulfur and phosphorus due to irradiation has also been measured [28].

\section{Alloy 617}

Alloy 617 is not precipitation hardened and, at the time of the 2009 experiments, its radiation response was largely unknown [30]. It was irradiated in the High Flux Isotope Reactor (HFIR) to 1.2-1.6 dpa at temperatures of $550-700^{\circ} \mathrm{C}$ and tensile tested at elevated temperatures in air atmosphere [30]. Alloy 617 had increased YS and UTS after irradiation, but TE decreased after irradiation and decreased with increasing test temperature to a minimum of $\sim 10 \%$ at $700^{\circ} \mathrm{C}$ [30]. Other key properties, such as swelling or creep, were not measured. Alloy 617 has been neutron irradiated only to $\sim 1.5 \mathrm{dpa}$, so conclusions about its performance cannot be drawn [28].

\section{Hastelloy X}

Hastelloy $X$ has a nominal composition of $50 \% \mathrm{Ni}, 17 \% \mathrm{Fe}, 22 \% \mathrm{Cr}, 9 \% \mathrm{Mo}, 1 \% \mathrm{Co}$, and $0.6 \% \mathrm{~W}$ [28]. It was not the focus of irradiation experiments during the time of the MSRE; but it was tested with Te exposure and did not form the types of intergranular cracks that Hastelloy $\mathrm{N}$ formed in the MSRE [9], perhaps because of its higher $\mathrm{Cr}$ content ( $\sim 22 \%$ ) compared with Hastelloy N ( 7\%) [9]. Some neutron irradiation has been completed on Hastelloy $X$. It was found to have very high swelling when irradiated at $\sim 500-600^{\circ} \mathrm{C}$, with the largest swelling at $600^{\circ} \mathrm{C}$. This may be due to the precipitation of carbon [28]. Neutron irradiation of Hastelloy $X$ in Experimental Breeder Reactor (EBR) II at $600^{\circ} \mathrm{C}$ resulted in approximately $80 \%$ swelling [29]. This is in contrast to the results from ion irradiation results, which showed that swelling is a function of $\mathrm{Ni}$ content for different Ni-based alloys and that Hastelloy X has enough Ni to have very low swelling [29]. In fact, the very high swelling of Hastelloy $X$ under neutron irradiation is not understood, and its $\mathrm{Ni}$ content should put it in the low-swelling category [29]. There are fewer neutron irradiation data for Hastelloy X than other Ni alloys, such as alloy PE16, but Hastelloy X and Hastelloy XR (among others) are considered for applications above $760^{\circ} \mathrm{C}$ [28]. Hastelloy $\mathrm{X}$, as well as many other $\mathrm{Ni}$ based alloys, loses ductility after irradiation; the loss of ductility is often attributed solely to He generation, but there may be other factors at play. As stated in a review of Ni-alloys, Rowcliffe et 
al. referred to the knowledge gaps for Hastelloy $X$ by stating that “...post-irradiation microstructural characterization has not been sufficiently rigorous to define the relative significance of phase instabilities, solute segregation, radiation hardening and He generation. Consequently the mechanisms of ductility loss have not been convincingly identified" [28].

In one experiment in 1972, Hastelloy $X$ was irradiated in EBR-II to $5.5 \times 10^{22} \mathrm{n} / \mathrm{cm}^{2}(E>0.1 \mathrm{MeV})$ at $600-650^{\circ} \mathrm{C}$ in tensile and disc geometries [38]. Swelling was discovered in 1967, so this experiment was looking for swelling-resistant alloys and used immersion density measurements [38]. Under these conditions, Hastelloy $X$ swelled by $0.6-2.1 \%$, which was more than the other alloys tested, Incoloy 800 and Inconel 625 [38]. Microstructure observations showed a low number density of large, 250-1000 nm diameter voids [38]. Large precipitates that were rod shaped and 700-1000 nm long, likely $\mathrm{M}_{6} \mathrm{C}$-type carbides, also formed during irradiation [38].

\section{Alloys 230 and 120 ,}

As of the review by Rowcliffe et al. in 2009 , no neutron irradiation experiments had been completed on alloys 230 or 120 [28].

\section{$\underline{\text { Inconel } 625}$}

After irradiation at $\sim 10-15 \times 10^{26} \mathrm{n} / \mathrm{m}^{2}(\mathrm{E}>0.1 \mathrm{MeV})$ and $15-25 \times 10^{26} \mathrm{n} / \mathrm{m}^{2}(\mathrm{E}>0.1 \mathrm{MeV})$ at temperatures of $400-650^{\circ} \mathrm{C}$, Inconel 625 had less than $\sim 1 \%$ swelling for all cases [29]. In another experiment, Inconel 625 was irradiated in EBR-II to $5.5 \times 10^{22} \mathrm{n} / \mathrm{cm}^{2}(\mathrm{E}>0.1 \mathrm{MeV})$ at $600-650^{\circ} \mathrm{C}$ in tensile and disc geometries [38]. The purpose of this experiment was to identify swelling-resistant alloys, and it used immersion density measurements [38]. For these conditions, Inconel 625 densified by up to $0.6 \%$ and voids were not observed in the microstructure [38]. After irradiation, this alloy had many disc-shaped precipitates, 100-200 nm in diameter and 10-20 nm thick, that appeared to be $\mathrm{Ni}_{3} \mathrm{Nb}$ and were partially coherent with the matrix [38]. Other key properties, such as tensile or creep, were not measured.

\section{$\underline{\text { Others }}$}

Haynes 214, Mar-M 004, and M22 were suggested for use in molten salts up to $850^{\circ} \mathrm{C}$ [24]; but it is unclear if there are neutron irradiation data for these alloys. If the operating temperature is above $850^{\circ} \mathrm{C}$, another solution was suggested-such as an oxide-dispersion-strengthened steel as the structural material and a Ni-based coating layer on the salt side of the steel [24]; but such a coating may not have been tested.

\subsubsection{Conclu ding remarks and gap analysis}

A large variety of Ni-based alloys have been developed and suggested for use in Gen IV reactors where there is a need for high-temperature strength. Few to none of the proposed alloys have been specifically tested for MSR use. In general there is less understanding of neutron damage in $\mathrm{Ni}$-based alloys than in austenitic stainless and ferritic-martensitic steels [28]. There is not a full combined understanding of $\mathrm{Ni}$ alloy degradation under neutron irradiation [29]. A 2017 review of materials for Gen IV reactors by Allen et al. considered the main issues for Ni-based alloys in terms of capabilities of the materials, rather than considering the availability of data or understanding of the mechanisms [24]. They summarized the general performance issues for Nibased alloys in Gen IV reactors at service temperatures of $\sim 350-650^{\circ} \mathrm{C}$ as being $\mathrm{He}$ embrittlement, creep strength, swelling and embrittlement, corrosion, intergranular stress 
corrosion cracking, and irradiation-assisted stress-corrosion cracking. For service temperatures above $650^{\circ} \mathrm{C}$, they list the main limiting factors as creep, toughness, and He embrittlement [24].

Typically, Ni-based alloys lose tensile ductility when irradiated to $10-15 \mathrm{dpa}$ at $400-600^{\circ} \mathrm{C}$, and swelling is a concern [28]. Depending on the dose expected for Ni alloys in an MSR, different factors will be limiting: for high-dose applications, swelling will need to be considered; but for lower doses, long-term phase stability should be considered [28]. The relationship of the percentage of $\mathrm{Ni}$ in an alloy to the swelling under neutron irradiation is not fully understood [29]. For example, Hastelloy $X$ has had severe swelling measured for neutron irradiation at $600^{\circ} \mathrm{C}$, so its potential use would depend on the temperature and dose.

Helium production does cause some embrittlement, but certain brittle phases may also form and contribute to the embrittlement of Ni-based alloys; the relative importance of these factors is still under debate [29]. Much of the phase transition and precipitate behavior during irradiation is unknown [29]. More microstructural characterization is needed to understand the mechanisms of embrittlement.

The irradiation damage in Ni alloys may be addressed by alloy tailoring, processing optimization, GBE, or mechanical alloying with nanoclusters. The activation of the materials should be considered, both for developing the alloys and for the eventual need to dispose of the materials after use in a reactor. Special procedures must be used to examine high-Ni alloys after neutron irradiation at ORNL; some alloying elements, such as Co, may make it impossible to examine those $\mathrm{Ni}$ alloys with microscopy after neutron irradiation [30].

Of the alloys mentioned in this report, there are probably the most data for PE16; but it is unclear if there are enough data. For instance, the review papers did not mention thermal conductivity, so that and other properties necessary for MSR design may not have been tested for PE16. It is also unclear whether PE16 has been tested in a systematic way across the temperatures and fluences relevant to MSRs.

For the other Ni alloys, there is some general knowledge about their trends and mechanisms; but as shown in examples here, the different $\mathrm{Ni}$ alloys form different phases and precipitates under irradiation. Therefore, the specific degradation mechanisms can differ among similar alloys. There is not sufficiently comprehensive knowledge to predict the behavior of a new Ni-based alloy based only on data for other Ni-based alloys; each one that is considered would need to be tested with neutron irradiation. Many of the Ni alloys have had little or no testing under neutron irradiation, so a serious effort would be needed to gather a database of their thermal, physical, and mechanical properties.

\subsection{Alloy 800 and $800 \mathrm{H}$}

Alloy $800 \mathrm{H}$ has the same base composition as Incoloy alloy 800 (Fe, $20 \% \mathrm{Cr}, 32 \% \mathrm{Ni}$ ) but with a minimum grain size of $60 \mu \mathrm{m}$ [39]. Alloy $800 \mathrm{H}$ is an austenitic alloy, is considered for Gen IV applications, and is code certified up to $760^{\circ} \mathrm{C}$ [39]. Alloy $800 \mathrm{H}$ is solid solution strengthened as well as strengthened by Ti nitrides and carbides and $\mathrm{M}_{23} \mathrm{C}_{6}$ and $\mathrm{M}_{6} \mathrm{C}$ type precipitates [40]. It is unclear if this alloy meets all the requirements for MSR use, but it is included here as a potential option and an example of an alloy that has been analyzed with modern materials science methods. 


\subsubsection{Summary of previous work}

The authors of Ref. [39] consider there to be few irradiation data available on alloy $800 \mathrm{H}$. They performed $5 \mathrm{MeV} \mathrm{Ni}^{+}$implantation and TEM analysis of the irradiation defects. The detailed composition was Fe balance; 0.069 wt \% C; 0.76 wt \% Mn; 0.014 wt \% P; 0.001 wt \% S; 0.13 wt \% Si; 31.59 wt \% Ni; 20.42 wt \% Cr; 0.57 wt \% Ti; 0.42 wt \% Cu; and 0.50 wt \% Al. The unirradiated material has no precipitates; after $5 \mathrm{dpa}$ ion irradiation, faulted dislocation lops were observed but no voids or precipitates [39]. After 50 dpa ion irradiation, faulted dislocation loops were still observed that were slightly smaller in size and higher in density than the lower-dose sample, and small precipitates $\sim 5.9 \mathrm{~nm}$ in size were observed. The authors postulated that the precipitates may have influenced the dislocation loops, making make them smaller at the higher dose [39]. It was a positive feature that no voids were seen, because other steels such as SS 316 have voids and swelling under similar irradiation conditions [39]. Of course, the ion-irradiated microstructure of $800 \mathrm{H}$ has been seen to differ from the neutron-irradiated microstructure [41]. Alloy 800 was measured as having very large swelling after neutron irradiation at 427 and $510^{\circ} \mathrm{C}$ [28].

In a 1972 experiment, Incoloy 800 was irradiated in EBR-II to $5.5 \times 10^{22} \mathrm{n} / \mathrm{cm}^{2}(E>0.1 \mathrm{MeV})$ at $600-$ $650^{\circ} \mathrm{C}$ in tensile and disc geometries [38]. Swelling was discovered only in 1967, so this experiment was looking for swelling-resistant alloys using immersion density measurements. For these conditions, $0.05-0.5 \%$ swelling was measured. The microstructure revealed pores or voids in the range of 25-150 nm diameter and another population of voids $<5 \mathrm{~nm}$ that may have been He bubbles [38]. Additionally, matrix carbide particles were observed that were $\sim 5 \mathrm{~nm}$. In the same experiment, Hastelloy $X$ and Inconel 625 were also irradiated; Hastelloy $X$ had greater swelling and Inconel 625 had less swelling than Incoloy 800 [38].

GBE started in the 1980s [42], so it was not a technique available at the time of the MSRE. GBE has been shown to improve properties such as strength, creep strength, and resistance to stress corrosion cracking in certain metals, including Ni-based alloys [43]. To determine the effect of a GBE process, the grain boundaries are examined and categorized using the coincidence site lattice model, which groups grain boundaries into three categories: (1) those with misorientation angles of less than $15^{\circ},(2)$ those with values of sigma $(\Sigma)$ between 3 and 29 , and (3) those general boundaries that have sigma values greater than 29 [42]. The alloying elements, grain sizes, and crystallographic texture all affect the grain boundary character distribution [43]. Alloy $800 \mathrm{H}$ was used for GBE, and the method used was thermomechanical processing (TMP) of $\sim 6 \%$ cold work reduction, followed by annealing at $1050^{\circ} \mathrm{C}$, ending with a water quench [42]. TMP can not only change the grain boundary type but also change the precipitate type or cause phase changes, so these factors must also be considered. The TMP $800 \mathrm{H}$ and as-received $800 \mathrm{H}$ were neutron irradiated and analyzed with TEM, EBSD, and atomic force microscopy (AFM) [42]. With TEM, the precipitates in the unirradiated TMP $800 \mathrm{H}$ were observed directly and identified as $\mathrm{Ti}(\mathrm{C}$, $\mathrm{N}$ ) and $\mathrm{Cr}_{23} \mathrm{C}_{6}$ type and were typically less than $200 \mathrm{~nm}$. EBSD confirmed that the TMP increased the number of low-sigma coincident site lattice boundaries and reduced the general type of grain boundary [42]. AFM was useful because the precipitates had different hardnesses from the matrix [42].

Samples of TMP and as-received $800 \mathrm{H}$ and of TMP and as-received Inconel alloy 617 were irradiated in HFIR and subjected to tensile and impact tests [40]. After neutron irradiation, the TMP, irradiated and tensile tested at $580^{\circ} \mathrm{C}$, had increased strength and only a slight decrease in ductility compared with the as-received $800 \mathrm{H}$ irradiated and tested at the same conditions [30, 40, 42]. The results are promising; however, the $800 \mathrm{H}$ was irradiated to less than $2 \mathrm{dpa}$ [30], so higher dose exposures would be needed to see if the benefit remains. Low-angle grain 
boundaries are stronger, so GBE to increase the fraction of low-angle grain boundaries could improve the tensile strength and reduce intergranular fracturing [43]. Some of the improvement was from the improved grain boundaries and some was from the nano-precipitates that formed during TMP [42]. There was only a slight improvement from the TMP versus as-received samples for materials irradiated and tensile tested at $600^{\circ} \mathrm{C}$ [40]. The benefits of TMP were stable after annealing for $1000 \mathrm{~h}$ at $760^{\circ} \mathrm{C}$ for $800 \mathrm{H}$ and at $1000^{\circ} \mathrm{C}$ for alloy 617 [40]. For $800 \mathrm{H}$ (and some other $\mathrm{Ni}$ alloys) $\mathrm{M}_{23} \mathrm{C}_{6}$ carbides are common but reduce creep strength, partially because of interaction of these carbides with grain boundaries at high temperatures [43]. The type of grain boundary affects interaction with precipitates and void formation [43]. GBE by TMP must be carefully optimized for a material, because it is also possible to perform TMP that is detrimental to the mechanical properties [43]. Alloy $800 \mathrm{H}$ was suggested for use in molten salts up to $850^{\circ} \mathrm{C}$ [24], but it is unclear if irradiation data have been collected at that temperature. Also, alloy $800 \mathrm{H}$ may have a severe drop in mechanical properties above $700^{\circ} \mathrm{C}$ [44], so its temperature of use is under debate.

\subsubsection{Conclu ding remarks and gap analysis}

Alloy $800 \mathrm{H}$ is a high-temperature $\mathrm{Fe}-\mathrm{Ni}-\mathrm{Cr}$ alloy that is being considered for certain Gen IV reactor applications. Some limited neutron data at elevated temperatures relevant to an MSR have been collected. Also, GBE has been used on $800 \mathrm{H}$ successfully to improve its mechanical properties (primarily tensile) after neutron irradiation, and its microstructure has been examined in detail. Some work has been completed on code certification of $800 \mathrm{H}$ for nuclear applications [39]. Unlike other alloys, such as the Hastelloy family, $800 \mathrm{H}$ has been examined by advanced microscopy techniques to elucidate the mechanisms of irradiation damage and the role of precipitates. The gaps include synergistic effects of salt exposure and neutron irradiation and the lack of a full database of all relevant thermal, physical, and mechanical properties (including swelling, thermal conductivity, tensile strength, thermal creep, and irradiation creep) at relevant temperatures and neutron doses for normal and off-normal reactor operation.

\subsection{Graphite}

\subsubsection{Summary of previous work}

Graphite has a hexagonal crystal structure, so bonding is close within the plane (a-direction) and less strong between layers (c-direction). Under irradiation, graphite grains grow in the c-direction and shrink in the a-direction [45]. Graphite's thermal, physical, and mechanical properties change with neutron irradiation; and they may be complicated by functions of temperature and irradiation dose because generally graphite densifies at low fluence, followed by swelling as dose increases [45]. At high doses, graphite can lose structural integrity and crumble. Every grade of graphite behaves differently under irradiation, so each must be experimentally tested. Thus far, models do not exist that can predict the behavior of one graphite grade based on the measurements of a different grade. When graphite was first used commercially, for example, in the construction of early nuclear reactors and experiments, the graphite was fabricated from natural deposits of graphite. The consequence was that each natural deposit of graphite had different properties; a limited amount was available, based on the deposit size; and that graphite cannot be replicated precisely today [45].

In MSRs, a graphite moderator must be capable of withstanding neutron fluences of at least $3 \times 10^{22} \mathrm{n} / \mathrm{cm}^{2}$, the estimated fluence at which the graphite structure would consist of sufficient cracks to be permeable to xenon [22]. The graphite in a single-fluid MSR serves as a medium for the fuel salt, defining flow patterns and supporting its own weight; it has no structural purpose in 
an MSR. Nuclear-grade graphite is required to be stable against radiation-induced distortion and damage (permeability) by the fuel-bearing molten salt [22]. Dimensional changes followed by crack formation in graphite may allow the fuel salt to penetrate the graphite, and the graphite surfaces may need to be sealed with pyrocarbon to prevent xenon penetration. However, a pyrocarbon coating can cause premature expansion to occur at lower fluences than when it is absent [22]. Other remedies related to reactor operation, such as reduction of peak neutron flux and salt flow rate through the core, can be used to minimize these problems in graphite. Even though commercial graphite is available, more testing of it is required [22].

Although graphite had been used in many other fission reactors since the early days of investigating fission, the needs for an MSR were unique because of the much higher neutron fluence expected and the need for hermeticity [3]. The MSRE program estimated that graphite would need to withstand $\mathrm{a} \sim 1 \times 10^{22} \mathrm{n} / \mathrm{cm}^{2}$ (E>0.18 MeV) fluence per year for 3-5 years before being replaced [3]. Graphite in an MSR would also need to have low permeability for the salt, fission products (solids and gases), and fuel. For example, ${ }^{135} \mathrm{Xe}$ gas, a fission produce, is a strong thermal neutron absorber. If ${ }^{135} \mathrm{Xe}$ were allowed to diffuse into the graphite and accumulate, it would poison the reactor [3]. CGB graphite was the grade used in the MSRE, and it was sufficient for the MSRE; but a full-scale reactor would have approximately 2 orders of magnitude more neutron fluence than the MSRE and could withstand much less permeation of gases into the graphite [3]. The CGB graphite was made from petroleum needle coke bonded with coal-tar pitch and was produced specifically for the MSRE. It had superior properties compared with the standard graphite of the time [3]. There are now other improved grades of graphite for nuclear applications-for example, grade G347A produced by Tokai Carbon [45]. Molten salts do not wet graphite under typical operating pressure, so the small pores that graphite contains do not fill with salt [3]. The best He permeability ("best" here means lowest) for graphite at the time of the MSRE was $\sim 3 \times 10^{-4} \mathrm{~cm}^{2} / \mathrm{s}$, but approximately $\sim 1 \times 10^{-7} \mathrm{~cm}^{2} / \mathrm{s}$ was thought to be needed [3]. If thinner graphite sections were used, even smaller permeability values would be needed. A thin coating on the surface of graphite could reduce the permeability of gases into the graphite [3], but such a coating would need to be designed and tested to remain continuous and attached to the graphite during neutron irradiation and temperature cycles.

Isotropic graphite was recognized in the MSRE time frame as superior in terms of dimensional stability and radiation tolerance, but it was not sufficiently developed for commercial production and for the low permeability that was needed [3]. Significantly more irradiation data and properties evaluation (e.g., creep) were needed [3]. The geometry of the graphite components in the design needs to be chosen to minimize the impact of dimensional changes from neutron irradiation [3].

While graphite was one of the two materials used in the MSRE construction, and graphite samples were included in the surveillance samples in the MSRE, reports on the MSRE component and surveillance specimen analysis [10-13] mention the graphite results sparingly. It is unclear if the graphite specimens from the MSRE were tested in any way, such as mechanical or thermal tests or elemental analysis.

Since the MSRE time frame, there have been many advancements in the production of graphite and understanding of its behavior under neutron irradiation. Several commercial grades of graphite are now available and have been or are being tested for nuclear applications. The specific properties of each graphite grade are different, and only one example is presented in this report. Some of the trends may be shared with other graphite grades, but a particular grade that would be used for an MSR would need to be specifically tested. 
A fine-grain, isotropic graphite, grade $\mathrm{G} 347 \mathrm{~A}$, produced by Tokai Carbon was irradiated in the HFIR at temperatures of $\sim 395^{\circ} \mathrm{C} \pm 62^{\circ} \mathrm{C}, 459^{\circ} \mathrm{C} \pm 37^{\circ} \mathrm{C}, 535^{\circ} \mathrm{C} \pm 33^{\circ} \mathrm{C}, 684^{\circ} \mathrm{C} \pm 41^{\circ} \mathrm{C}$, and $738^{\circ} \mathrm{C}$ $\pm 43^{\circ} \mathrm{C}$ to fluences of up to $4 \times 10^{22} \mathrm{n} / \mathrm{cm}^{2}$ [E>0.1 MeV] (approximately $30 \mathrm{dpa}$ ) [45]. It is useful to examine this irradiation because the temperature range covers appropriate temperatures for a potential MSR, and the fluence of $4 \times 10^{22} \mathrm{n} / \mathrm{cm}^{2}$ [E $>0.1 \mathrm{MeV}$ ] is similar to the fluence that the MSRE team estimated that graphite would need to withstand $\left(\sim 1 \times 10^{22} \mathrm{n} / \mathrm{cm}^{2}[\mathrm{E}>0.18 \mathrm{MeV}]\right.$ each year for 3-5 years) before replacement [3]. As opposed to a rolling direction common for metals, the graphite specimens were labeled in terms of a direction parallel to gravity during molding and the two perpendicular directions [45].

Many thermal and mechanical properties of the graphite were measured before and after irradiation. With regard to dimensional and volume changes, G347A shrinks and then expands with increasing fluence, so the density increases initially and then decreases (Figure 40) [45]. Asproduced graphite contains Mrozowski cracks; and with low fluence irradiation, c-direction growth fills in the cracks and the a-direction shrinks. Thus, overall, the volume decreases and density increases [45]. At medium fluence, the c-direction growth continues and outpaces the a-direction shrinking, so new cracks form and a turn-around point is reached at which the volume is minimized. There is a lower turn-around fluence for higher-temperature irradiation [45]. As irradiation continues, c-direction growth continues, and the material swells but creates internal cracks and pores until it tears itself apart. This pattern of dimensional change with increasing irradiation fluence is seen in most graphite. The G347A grade is considered isotropic because its coefficient of thermal expansion (CTE) in the unirradiated condition is essentially even for the different directions. However, it had anisotropic dimensional changes after neutron irradiation [45].

The Young's modulus is related to density change, so it increases and then decreases as neutron dose increases [45]. The electrical resistivity showed a rise, a plateau, and then another rise with increasing fluence; the length of the plateau was determined by the irradiation temperature, with longer plateaus for lower-temperature irradiation. The equibiaxial strength increased and then decreased with increasing neutron fluence [45]. The thermal conductivity of the graphite at $50^{\circ} \mathrm{C}$ decreased with increasing neutron fluence for all irradiation temperatures. The thermal conductivity tested at the irradiation temperature had a large drop initially for small doses and then continued to decrease slightly with increasing neutron dose. The CTE first increased and then decreased with increasing neutron fluence [45]. Considering that the highest fluence tested in Ref. [45] corresponds to the estimated lifetime dose of the graphite in a MSR reactor [3], if the G347A graphite were used in an MSR, significant changes in the thermal, electrical, dimensional, and mechanical properties would be expected over the 3-5 year life of the component. The $30 \mathrm{dpa}$ level is past the turn-around point for all temperatures tested, so all properties that are related to density would have both increased and decreased by the end of the life of the component. This 30-dpa level of irradiation is equivalent to the full-dose measured range in Figure 40, showing the large change in dimensions over that lifetime. It is unclear whether the level of property changes measured by Ref. [45] would be acceptable in an MSR design. The main challenges for graphite in a MSR are property changes during irradiation [24], joining [24], and gas permeation [3]. 


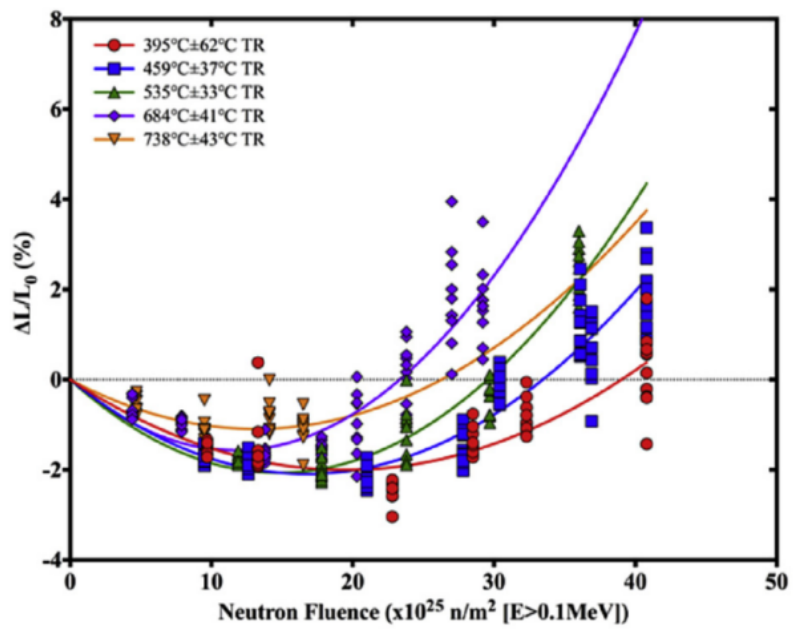

(a)

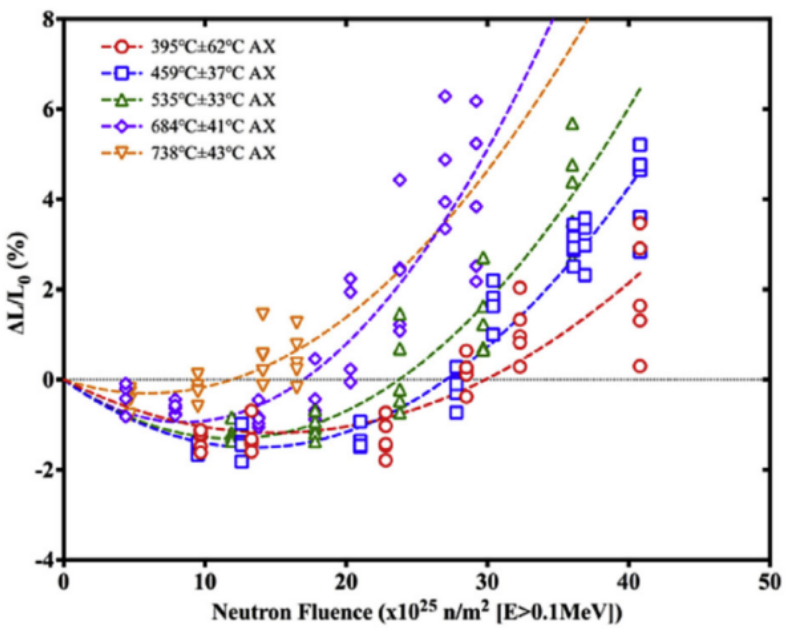

(b)

Figure 40 G347A graphite (a) transverse and (b) axial dimensional changes as a function of irradiation temperature and dose. Reproduced from Ref. [45].

\subsubsection{Conclu ding remarks and gap analysis}

There are more useful property data for graphite than for many of the metals considered in this review, so there are enough data to identify some fundamental issues. The review of materials issues for Gen IV reactors by Allen et al. listed the performance issues for graphite as creep strength, swelling, toughness, and thermal conductivity [24]. The recent experiments on graphite have measured thermal and mechanical properties under neutron irradiation but have not measured gas permeability. Measurements for gas permeability are needed; and based on the results, there may be a need to develop a permeation barrier coating method or develop graphite that is less porous.

For the specific grade of graphite used in an MSR, the irradiated properties would need to be measured, because each grade of graphite behaves differently. Even though graphite is not a structural component in designs such as the MSRE, under a high enough neutron fluence, the graphite crumbles; so the experimental data to set upper fluence limits are important for graphite. Additionally, experiments were not found in the cited literature for this report that tried synergistic effects on graphite, such as salt exposure plus neutron irradiation. Also, based on the MSRE reports cited, little testing was completed on graphite. For the few tests that were completed on graphite used in the MSRE, the data are useful for considering trends, but none of those specific data can be used because the MSRE graphite was a different grade from today's graphite. Any MSR design must account for the changes in the dimensions of the graphite components over time, first shrinking and then swelling.

\subsection{Silicon Carbide}

Silicon carbide composites are a family of materials based on SiC fibers encased in a SiC matrix. $\mathrm{SiC}$ has been considered for numerous structural and specialized functions in fission and fusion reactors [46]. The composites can vary by the generation of fiber used, the interlayer, the method of matrix densification, and the fiber architecture [44]. There are currently three generations of $\mathrm{SiC}$ fibers that have been commercially produced, and only the Gen III fibers are suitable for nuclear 
applications [44]. The fact that only Gen III fibers can be used for nuclear applications may not be well known; for instance, recent experiments on SiC in salt corrosion for MSR applications tested Gen II fibers, and therefore their data may not be useful [47]. Pyrolytic carbon is the most commonly used interlayer and is best for nuclear applications [48]. Other interlayer materials could be used if the interlayer materials are more compatible with molten salts, but it does take significant R\&D effort to develop a new interlayer [44]. For matrix densification, chemical vapor infiltration (CVI) is the best method, and nano-infiltration and transient eutectic-phase process are improving and may be considered $[44,48]$. The processing route has a significant influence on the resulting properties and irradiation resistance, so must be chosen carefully; high-purity, stoichiometric, crystalline $\mathrm{SiC}$ in the matrix is required for irradiation resistance [44]. Continuous fiber is the best architecture for nuclear applications; bonded fiber may be an option; and chopped fiber-type composite $\mathrm{SiC}$ is unsuitable [44]. SiC as a pure compound generally has good irradiation resistance, chemical inertness, and low activation, which make it promising for nuclear applications [44].

\subsubsection{Summary of previous work}

A report in 2007 by Katoh et al. examined SiC composites for use as a fuel cladding in the AHTR, which has liquid fluoride salt coolant and solid high-temperature fuel [44]. From their perspective, the critical feasibility issues for $\mathrm{SiC}$ for this application were (1) corrosion of $\mathrm{SiC}$ in liquid salts, (2) effects of higher-dose neutron irradiation on $\mathrm{SiC}$ composites, (3) static fatigue failure of SiC composites, (4) long-term radiation effects (e.g., irradiation creep), and (5) fabrication technology for hermetic tubes and end caps [44].

For SiC, there are unanswered questions about corrosion and longer-term irradiation effects such as irradiation-induced swelling and creep [44]. Additionally, for SiC composites, properties such as strength, fracture toughness, thermal conductivity, and fatigue depend on the fabrication of the composite [44]. Most designs will require joints; there are various methods of joining $\mathrm{SiC}$ composites, and each has a different degree of radiation resistance [44]. If corrosion is too high, a carbon-type coating on $\mathrm{SiC}$ could be considered, but carbon has a complicated behavior of shrinking and then swelling with increasing neutron irradiation, which may cause it to debond from $\mathrm{SiC}$ [44]. Alternatively, $\mathrm{SiC}$ has been proposed as a coating on graphite to protect the graphite from corrosion [47].

Tensile data are a better indication of the strength of a SiC fiber composite than flexure strength; the reason is that the part of a composite in compression in a flexure test will skew the strength value higher, and fiber pullout can result in an artificially high strain [44]. Thermal conductivity is usually anisotropic because of the composite architecture [44]. An additional concern is slow crack growth, which is different from and may occur in addition to creep [44]. In general, many of the properties can be anisotropic and this must be considered in the design [44].

Irradiation data were collected at $300,400,500$, and $800^{\circ} \mathrm{C}$ and up to 10 dpa on pure SiC [44]. Pure SiC has acceptable fracture strength, up to 10 dpa [44], which was the highest tested at the time. Multiple tests must be completed to calculate the Weibull statistics for SiC because it is a brittle material [44]. The effects of radiation damage on pure $\mathrm{SiC}$ are generally understood, and they form the basis for understanding the composite behavior [44]. If the $\mathrm{SiC}$ is not stoichiometric, has other phases in it, or has impurities, it performs poorly under neutron irradiation [44]. CVI $\mathrm{SiC} / \mathrm{SiC}$ composites have also been neutron irradiated at temperatures from 300 to $1000^{\circ} \mathrm{C}$ and up to $12 \mathrm{dpa}$ [44]. They showed little to no change in mechanical properties after irradiation under these conditions [44]. 
A large experimental effort was completed by Katoh et al. [48] to irradiate CVI SiC/SiC composites with Gen III fibers and a pyrolytic carbon interlayer in the HFIR at $800^{\circ} \mathrm{C}$ to $5.9 \times 10^{25} \mathrm{n} / \mathrm{m}^{2}(\mathrm{E}>0.1$ $\mathrm{MeV}$ ) and at $1300^{\circ} \mathrm{C}$ to $5.8 \times 10^{25} \mathrm{n} / \mathrm{m}^{2}(\mathrm{E}>0.1 \mathrm{MeV})$, which are approximately 5.9 and $5.8 \mathrm{dpa}$, respectively [48]. Other $\mathrm{CVI} \mathrm{SiC/SiC} \mathrm{samples} \mathrm{were} \mathrm{also} \mathrm{irradiated} \mathrm{at} \mathrm{selected} \mathrm{temperatures}$ between 300 and $1300^{\circ} \mathrm{C}$ and at doses up to $12 \mathrm{dpa}$ [48]. Linear thermal expansion, thermal conductivity, Young's modulus at RT, swelling, tensile, single-fiber push-out, compression, and single-edge notched beam tests were all completed on the unirradiated and irradiated samples [48]. The thermal conductivity underwent a large decrease after a small dose, but then it saturated and did not continue to decrease as dpa increased up to at least $70 \mathrm{dpa}$ at $800^{\circ} \mathrm{C}$ [48]. For all other properties measured in the study besides thermal conductivity, the irradiation up to $\sim 5-$ $12 \mathrm{dpa}$ at elevated temperatures caused little to no change in the properties compared with the unirradiated values [48].

For $\mathrm{SiC}$, as for most ceramics, thermal conductivity is primarily phonon transport, which is disrupted after neutron irradiation to cause a decrease in the thermal conductivity [44]. The microstructural changes in $\mathrm{SiC}$ under neutron and ion irradiation have also been studied [49]. For irradiation between $\sim 150$ and $1000^{\circ} \mathrm{C}$, point defects cause swelling, which reaches saturation at $\sim 1$ dpa $[44,48]$. At those temperatures, silicon and carbon atoms that are knocked off their lattice sites are unlikely to be able to return, and the swelling is caused by the sum of these individual defects [48]. For irradiation at temperatures of $\sim 1000-1400^{\circ} \mathrm{C}$, the material is in a transition region; and above $1400^{\circ} \mathrm{C}$, vacancies on the silicon and carbon sites become mobile, and swelling occurs from void growth [48]. Swelling in $\mathrm{SiC}$ is generally less with higher irradiation temperatures [44]. The swelling in SiC appears to be small and known and is not expected to cause problems for designing nuclear components using SiC. SiC may experience thermal creep, which is dimensional change under stress at elevated temperatures; but independently, it may also experience irradiation creep, which is dimensional change caused by irradiation and stress [44]. Knowledge of these types of dimensional changes is necessary in designing a reactor, and more data must be collected for creep and irradiation creep in SiC [44]. Finally, the combined effects of salt exposure and neutron irradiation must be considered [44].

Higher-dose neutron irradiations have been completed on $\mathrm{SiC}-u p$ to 30-40 dpa at temperatures of $300-800^{\circ} \mathrm{C}$ [50]. The CVI SiC/SiC composites were tested for swelling, thermal conductivity, and elastic modulus and showed changes at low dpa that saturated and did not continue to decline as dose increased [50]. Flexural strength and electrical resistivity also showed little to no change after this level of neutron irradiation [50]. More recently, additional irradiations were completed up to $100 \mathrm{dpa}$ and dynamic Young's modulus, flexural strength, swelling, and microstructure were measured [51]. These high-dose irradiations did result in degradation in the flexural properties (Figure 41), which was primarily attributed to the behavior of the fiber/matrix interface [51]. The mode of failure was different between the two irradiation temperatures of 319 and $629^{\circ} \mathrm{C}$ (Figure 42). Swelling at this high dose was less than $1 \%$ for all temperatures and materials tested [51]. 


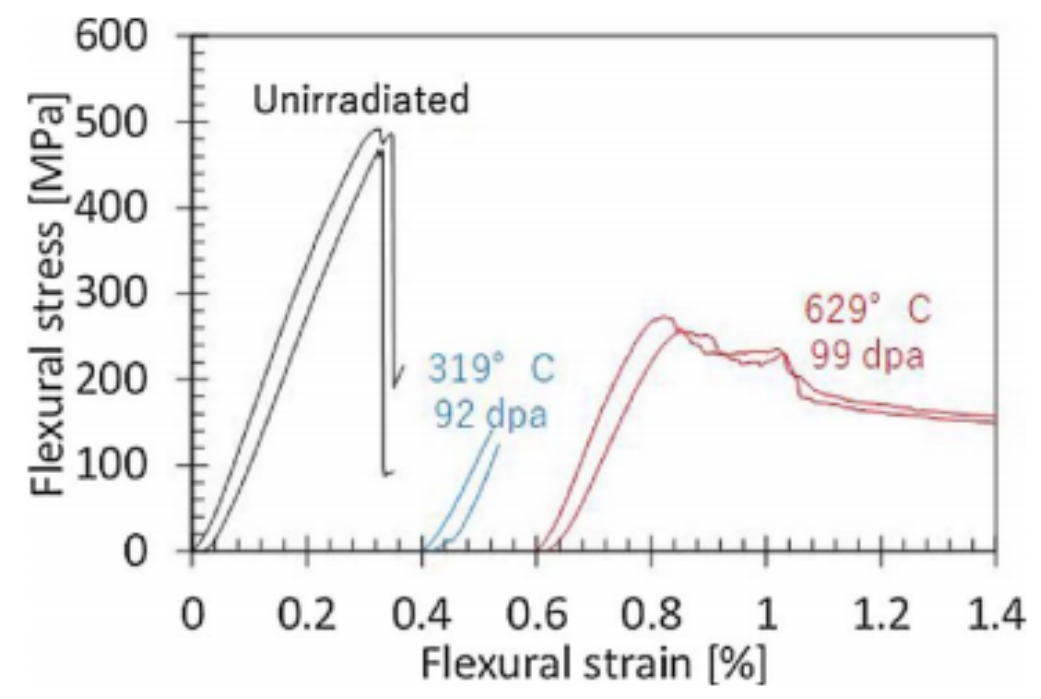

Figure $41 \mathrm{SiC} / \mathrm{SiC}$ composites irradiated to $\sim 100 \mathrm{dpa}$ had brittle flexure behavior at a $319^{\circ} \mathrm{C}$ irradiation temperature but retained ductility for the $629^{\circ} \mathrm{C}$ irradi ation case. Reproduced from Ref. [51].

(a) Non-irradiated

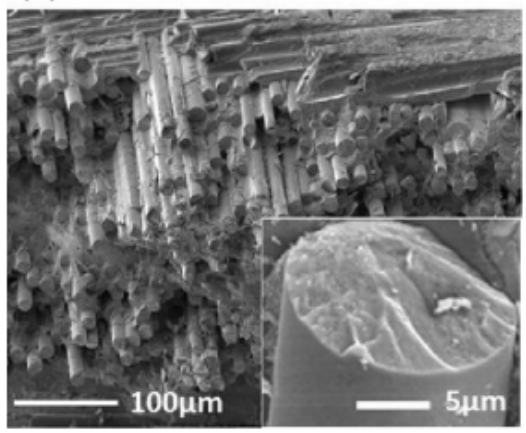

(b) Irradiated at $319^{\circ} \mathrm{C}$ to $92 \mathrm{dpa}$

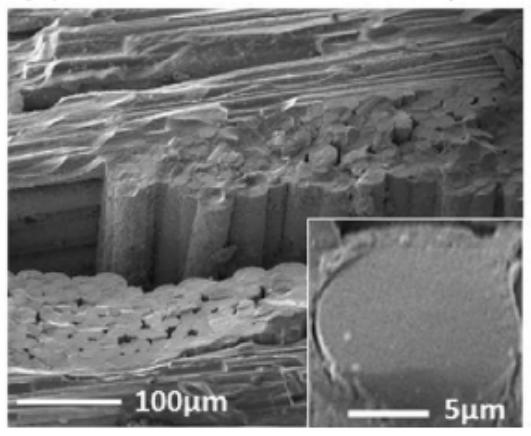

(c) Irradiated at $629^{\circ} \mathrm{C}$ to $99 \mathrm{dpa}$

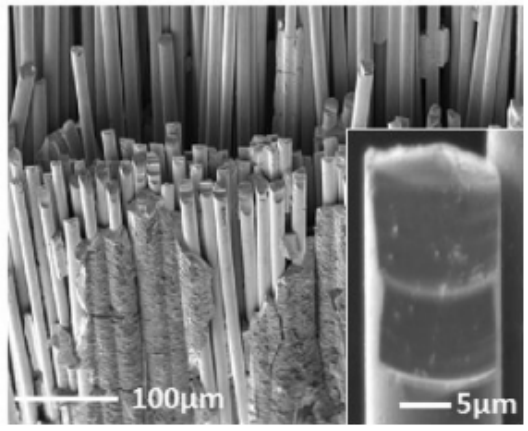

Figure 42 Fracture surfaces of flexural tests of $\mathrm{SiC} / \mathrm{SiC}$ composites before and after irradiation t o 100 dpa. Reproduced from Ref. [51].

One example of a combined irradiation and salt corrosion experiment was found for $\mathrm{SiC}$ by $\mathrm{Li}$ et al. [52]. Samples of $\mathrm{SiC}$ were irradiated with $70 \mathrm{keV} \mathrm{Si}$ ions to $2.5 \mathrm{dpa}$ at $650^{\circ} \mathrm{C}$ and then exposed to FLiNaK salt at $650^{\circ} \mathrm{C}$ [52]. A single-crystal wafer of $\mathrm{SiC}$ was used, and the estimated damage peak from the ion irradiation was $40 \mu \mathrm{m}$ [52]. Li et al. saw worse damage to the ion-irradiated SiC than to the unirradiated when both were exposed to the salt at elevated temperatures [52].

Although this is a useful topic to investigate, there were many issues with this preliminary study of the combined effects of irradiation and salt corrosion. The magnification at which they observed their sample surfaces was too low to see any of the surface damage from the ion implantation. There were no cross sectional images, no measurements of the salt chemistry to confirm silicon dissolved from the sample, and no higher-magnification SEM images to show whether the ion irradiation was leaving pores or channels on the surface that allowed salt ingress. Furthermore, the main analysis lacking from the article is that the authors did not consider that using a monoenergetic ion beam for implantation creates a non-uniform damaged zone and a highly stressed layer where the silicon ions are implanted. In fact, in other applications, monoenergetic 
ion implantation is used as a method for sectioning material or exfoliating a thin layer. This effect of ion implantation, rather than the effects of the salt, could have led to the peeling off of the surface layer. The artifacts of ion implantation, including blistering, surface morphology changes, sputtering, near surface strain, non-uniform damage profile and others, may have affected how the salt interacted with the surface. Additionally these same artifacts from ion irradiation differ from neutron irradiation effects, and so results from ion implantation experiments generally do not replicate neutron damage effects unless the studies are designed carefully to take the differences into account.

\subsubsection{Conclu ding remarks and gap analysis}

$\mathrm{SiC}$ has been studied via modern analysis techniques under neutron irradiation over a range of temperatures and doses relevant to MSRs. At least some data exist for many of its thermal, physical, mechanical, and microstructural properties after irradiation, some measured to doses as high as $100 \mathrm{dpa}$ [51]. The data available for SiC cover a broader range than those available for any of the metals in this report. Additionally, many of the degradation mechanisms are understood for $\mathrm{SiC}$. Data are available for irradiation creep to $\sim 30 \mathrm{dpa}$, so it needs to be determined whether designs can accommodate the measured dimensional changes [53]. Swelling was less than $1 \%$ for irradiations up to $100 \mathrm{dpa}$ and up to $630^{\circ} \mathrm{C}$ [51], but it would need to be measured for higher operating temperatures. Some data are still needed on longer-term effects on $\mathrm{SiC}$ exposed to irradiation, such as irradiation-enhanced static fatigue [44].

A knowledge gap remains regarding the hermeticity of $\mathrm{SiC}$ composites and joints of $\mathrm{SiC}$ components. Changes in thermal conductivity during irradiation are of concern because a decrease in thermal conductivity increases the temperature, causes thermal stress in the material, and may cause problems with differential swelling [54]. If a coating is needed on SiC components, the radiation tolerance of the coating would be a separate area of development and testing. There are few data for salt corrosion of $\mathrm{SiC}$ and fewer on synergistic effects of salt exposure and neutron irradiation.

\subsection{Common Issues for All Materials}

\subsubsection{Joints}

All designs will require some joints within the same material. MSR designs will likely require that several different materials be used for different regions of the reactor. Many of these dissimilar materials will need to be welded to one another. Additionally, those welded joints between similar and dissimilar materials will need to withstand neutron irradiation. Some work on welding Hastelloy $\mathrm{N}$ to Inconel 600 , austenitic SS, $\mathrm{Ni}$, and graphite was completed at ORNL during the MSRE period [3]. However, information is still lacking in this category. A full qualification program would need to include a systematic irradiation evaluation of welds relevant to a particular design. This would include metal-metal joints; special material joints, such as SiC material to SiC materials or graphite-graphite joints; and possibly metal to $\mathrm{SiC}$ or metal to graphite.

\subsubsection{Activation}

The neutron activation of alloys selected for an MSR design may need to be considered for alloy development, safety, and maintenance during plant operation, and the eventual disposal of the materials. High-Ni alloys require special procedures for testing and evaluation after neutron irradiation [30]. Certain alloying elements, such as $\mathrm{Co}$ and $\mathrm{Nb}$, greatly increase the activity after neutron irradiation and thus complicate handling of the alloys in a testing environment. Irradiation 
test reactors such as HFIR have limits on the amounts of many elements, including Co, that are allowed in test samples. If a desired alloy has too high a Co content, it could not be irradiated in a test reactor. Beyond the development of alloys, alloys with high activity while in service can also be problematic because remote maintenance methods or extra safety shielding may be needed. Additional considerations for minimizing activated material release in an accident scenario may be needed. At the end of the plant lifetime, the activation levels of the materials and the nuclides present determine the class of waste and dictate the methods needed for disposal. Although it is in a different context, an example of the elemental limits for fusion materials to qualify for Class $\mathrm{C}$ waste disposal is discussed in Ref. [55]. The activation level and the long-lived nuclides present depend on the neutron energy spectrum, so they would need to be evaluated for the neutron energy spectrum specific to MSRs. Thus, activation should be considered in the early stages of alloy refinement and reactor design.

\subsubsection{Tritium}

Tritium ( $\mathrm{T}$ ) will be produced in MSRs and is a concern because it is a radioactive and highly mobile isotope. There are several pathways to T production in an MSR. Boron is a common impurity in Ni-based alloys. The thermal neutron reactions of ${ }^{10} \mathrm{~B}$ release ${ }^{4} \mathrm{He}$ and ${ }^{7} \mathrm{Li}$. Both isotopes of $\mathrm{Li}$, ${ }^{7} \mathrm{Li}$ and ${ }^{6} \mathrm{Li}$, may also be components of the salt; Lithium- 6 reacts with thermal neutrons to release $\mathrm{T}$, and ${ }^{7} \mathrm{Li}$ reacts with energetic neutrons to release $\mathrm{T}$. Additionally, for reactions with higher-energy neutrons, there are two pathways for ${ }^{10} \mathrm{~B}$ reactions that directly release $\mathrm{T}$.

At the Molten Salt Reactor Workshop at ORNL in October 2017, it was estimated that an MSR would release $2500 \mathrm{Ci}$ of T per full power day [56]. If the MSR operates every day, it would release $95 \mathrm{~g}$ of $\mathrm{T}$ in a year. This is a much higher total than in existing fission reactors. For comparison, ITER, a nuclear fusion experiment in France, has been licensed to have a total site limit of $700 \mathrm{~g}$ of $\mathrm{T}$. ITER has many specialized systems devoted to keeping and handling the T so that the permitted amount is kept safely on site and not released. The conditions are, of course, vastly different for ITER compared with an MSR; but the point remains that $95 \mathrm{~g}$ of $\mathrm{T}$ per year is a sizable amount. Safe handling of $T$ needs to be considered from the design stage and planned for in the R\&D phase of an MSR.

Tritium was not discussed in any of the references cited in this report. While that does not prove that $T$ issues have not been studied for relevant MSR materials, it indicates that this issue is not typically discussed along with other materials property information relevant to reactors. For every material in an MSR, data for T permeation, diffusion, and retention will need to be experimentally measured for a range of relevant temperatures. For the safe operation of the reactor, the $T$ production and inventory will need to be predictable and measured. Additionally, it may be determined that permeation barrier materials or coatings are needed in areas of the reactor to reduce the $T$ spread. If those do prove necessary, they would require their own area of $R \& D$; however, some synergy could be leveraged with the fusion program, for which $T$ control is a major issue.

In addition to safety concerns, tritium may also damage the structural materials. For certain metals, hydrogen (including tritium) reacts to form hydride phases which are detrimental to the mechanical properties. The probability of reaction and phases created would be different for each material under consideration, so would need to be investigated. Moreover, tritium can cause corrosion of the materials. It is unknown what synergistic effects could occur between tritium, corrosion, and irradiation. 


\subsection{Recommendations}

\subsubsection{Recommendations for Hastelloy $\mathbf{N}$ and alloys based on Hastelloy $\mathbf{N}$}

Hastelloy $\mathrm{N}$ containing $\sim 1 \% \mathrm{Nb}$ appeared to be the best compromise of addressing irradiation embrittlement and having some resistance to Te-family element cracking (Section 3.1.2).

However, this alloy was developed late in the MSRE program, so had much less testing than the base Hastelloy N, which is not suitable for MSR applications. An irradiation program to measure mechanical properties and microstructural changes of Hastelloy $\mathrm{N}$ with $\mathrm{Nb}$ would greatly increase the knowledge and confidence in this alloy. Similarly, the Kurchatov Institute alloys based on Hastelloy $\mathrm{N}$ have some published promising corrosion data, but there is little to no irradiation information. An irradiation campaign for the Kurchatov Institute alloys would be required to determine their suitability for MSR use (Section 3.2.2).

Understanding carbide, precipitate, and phase change behavior in Hastelloy N-type alloys is critical to understanding and predicting their behavior under irradiation. Much was postulated about the microstructure features of Hastelloy N-type alloys during the MSRE-era projects, but tools were not available at the time to observe most of these features directly. For example, there is still an open question about the role of $\mathrm{He}$ in the embrittlement of these alloys. Any irradiation program should contain a dedicated effort to examine the microstructure with tools including high resolution TEM, SEM, and EDS. These tools could answer key questions about the mechanism of the irradiation embrittlement and Te-family surface cracking, which could lead to strategies to mitigate the degradation.

Methods such as grain boundary engineering (GBE) have generally been successful with Nibased alloys, so GBE may be considered for Hastelloy $\mathrm{N}$ to improve its radiation resistance. Additionally, since grain boundary cracking was a critical issue for Hastelloy $N$, the effect of GBE on the strength of the grain boundaries could be tested to see if it makes them more resistant to cracking.

\subsubsection{Recommendations for other Nickel -based alloys and Alloy $800 / 800 \mathrm{H}$}

Any of the Ni-based alloys developed or suggested for Gen IV reactor use would require a broad irradiation and corrosion testing program to confirm their suitability for an MSR (Sections 3.3.2 and 3.4.2). Swelling should be measured for the alloy to determine if it can be accommodated in the design. As for the Hastelloy $\mathrm{N}$, the microstructure, precipitates, and possible phase changes should be carefully examined to determine the causes of embrittlement. Helium production does cause some embrittlement, but certain brittle phases may also form and contribute to the embrittlement of Ni-based alloys; the relative importance of these factors is still under debate. The irradiation damage in Ni alloys may be addressed by alloy tailoring, processing optimization, GBE, or mechanical alloying with nanoclusters.

\subsubsection{Recommendations for graphite}

For the specific grade of graphite used in an MSR, the irradiated properties would need to be measured, because each grade of graphite behaves differently (Section 3.5.2). Even though graphite is not a structural component in designs such as the MSRE, under a high enough neutron fluence, the graphite crumbles; so the experimental data to set upper fluence limits are important for graphite. The other main gap for graphite is synergistic effects of salt exposure and neutron irradiation. 


\subsubsection{Recommendations for silicon carbide}

Data exists on $\mathrm{SiC}$ up to $100 \mathrm{dpa}$ and $630^{\circ} \mathrm{C}$, so additional irradiations at higher temperatures should be conducted depending on the desired operating temperature (Section 3.6.2). The hermeticity of $\mathrm{SiC}$ composites, corrosion behavior, and combined corrosion and irradiation behavior needs to be investigated for MSR applications.

\subsubsection{Recommendations for all materials}

Any material selected for MSR use must consider joint behavior under irradiation, activation of the constituent elements, and interaction with tritium as discussed in section 3.7. These three considerations should be part of any program in addition to the recommendations of mechanical property, microstructure, or other material-specific investigations recommendations in Section 3.8.

\subsection{References}

[1] P. Yvon and F. Carré, Structural materials challenges for advanced reactor systems, J. Nucl. Mater. 385(2) 217-222, 2009.

[2] G.E. Metzger, Survey of structural materials for the molten salt experimental (MOSEL) reactor, Nuclear Engineering and Design 7, 29-39, 1968.

[3] H.E. McCoy and Jr., and J.R. Weir, Jr., Materials Development for Molten-salt Breeder Reactors, ORNL-TM-1854, Oak Ridge National Laboratory, 1967.

[4] H.E. McCoy and D.A. Canonico, Preirradiation and Postirradiation Mechanical Properties of Hastelloy N Welds, Oak Ridge National Laboratory, ORNL-TM-2483, 1969.

[5] H.E. McCoy, Studies of the Carbon Distribution in Hastelloy N, ORNL-TM-1353, Oak Ridge National Laboratory, 1966.

[6] W.R. Martin and J.R. Weir, Effect of Elevated Temperature Irradiation on the Strength and Ductility of the Nickel-base Alloy, Hastelloy N, ORNL-TM-1005, Oak Ridge National Laboratory, 1965.

[7] H.E. McCoy, Jr., Effects of Irradiation on the Mechanical Properties of Two Vacuummelted Heats of Hastelloy N, ORNL-TM-2043, Oak Ridge National Laboratory, 1968.

[8] H.E. McCoy and R.E. Gehlbach, Influence of irradiation temperature on the creeprupture properties of Hastelloy-N, Nuclear Technology 11, 45-60, 1970.

[9] H.E. McCoy and B. McNabb, Intergranular Cracking of INOR-8 in the MSRE, ORNL4829, Oak Ridge National Laboratory, 1972.

[10] H.E. McCoy, Jr., An Evaluation of the Molten-Salt Reactor Experiment Hastelloy N Surveillance Specimens_First Group, ORNL-TM-1997, Oak Ridge National Laboratory, 1967.

[11] H.E. McCoy, Jr., An Evaluation of the Molten-Salt Reactor Experiment Hastelloy N Surveillance Specimens-Second Group, ORNL-TM-2359, Oak Ridge National Laboratory, 1969.

[12] H.E. McCoy, Jr., An Evaluation of the Molten-Salt Reactor Experiment Hastelloy $N$ Surveillance Specimens-Third Group, ORNL-TM-2647, Oak Ridge National Laboratory, 1970. 
[13] H.E. McCoy, Jr., An Evaluation of the Molten-Salt Reactor Experiment Hastelloy N Surveillance Specimens_Fourth Group, ORNL-TM-3063, Oak Ridge National Laboratory, 1971.

[14] H.E. McCoy, Jr., Status of Materials Development for Molten Salt Reactors, Oak Ridge National Laboratory, ORNL-TM-5920, Oak Ridge National Laboratory, 1978, p. 39.

[15] H.E. McCoy, Jr., Influence of Titanium, Zirconium, and Halfnium Additions on the Resistance of Modified Hastelloy N to Irradiation Damage at High TemperaturePhase I, ORNL-TM-3064, Oak Ridge National Laboratory, 1971.

[16] C.E. Sessions and E.E. Stansbury, Thermal Stability of Titanium-modified Hastelloy N at 650 and $760^{\circ} \mathrm{C}$, ORNL-TM-3321, Oak Ridge National Laboratory, 1971.

[17] H.E. McCoy, R.W. Gunkel, and G.M. Slaughter, Tensile Properties of Hastelloy N Welded after Irradiation, ORNL-TM-2858, Oak Ridge National Laboratory, 1970.

[18] S.J. Zhang, D.H. Li, H.C. Chen, G.H. Lei, H.F. Huang, W. Zhang, C.B. Wang, L. Yan, D.J. Fu, and $\mathrm{M}$. Tang, lon irradiation-induced swelling and hardening effect of Hastelloy N alloy, J. Nucl. Mater. 489, 180-186, 2017.

[19] K. Liu, J. Lin, L.-m. Bao, H.-x. Xu, L. Xu, Z. Liu, J.-r. Zeng, S.-I. Long, L.-I. Cao, J.-j. Li, L. yan, X.-I. Li, G.-I. Zhang, and Y. Li, Dose rate effect on micro-structure and hardness of Hastelloy-N irradiated by $\mathrm{Xe}$ ions, Journal of Nuclear Science and Technology 52(6), 829-36, 2014.

[20] M. Liu, Y. Lu, R. Liu, and X. Zhou, TEM investigation on the microstructural evolution of Hastelloy $\mathrm{N}$ induced by $\operatorname{Ar}(+)$ ion irradiation, Microsc Res Tech 77(2) 161-169, 2014

[21] J. Gao, L. Bao, H. Huang, Y. Li, Q. Lei, Q. Deng, Z. Liu, G. Yang, and L. Shi, ERDA, RBS, TEM and SEM characterization of microstructural evolution in helium-implanted Hastelloy N alloy, Nucl. Instrum. Methods Phys. Res. Sect. B: Beam Interact. Mater. Atoms 399, 62-68, 2017.

[22] J.R. Engel, H.F. Bauman, J.F. Dearing, W.R. Grimes, H.E. McCoy, Jr., Development Status and Potential Program for Development of Proliferation-Resistant Molten Salt Reactors, ORNL/TM-6415, Oak Ridge National Laboratory, 1979.

[23] W. Ren, G. Muralidharan, D.F. Wilson, and D.E. Holcomb, Considerations of alloy N for fluoride salt-cooled high-temperature reactor applications, ASME 2011 Pressure Vessels \& Piping Division Conference, Baltimore, Maryland, USA, 2011.

[24] T.R. Allen, K. Sridharan, L. Tan, W.E. Windes, J.I. Cole, D.C. Crawford, and G.S. Was, Materials challenges for Generation IV nuclear energy systems, Nuclear Technology 162(3), 342-357, 2008.

[25] V. Ignatiev and A. Surenkov, Alloys compatibility in molten salt fluorides: Kurchatov Institute related experience, J. Nucl. Mater. 441(1-3), 592-603, 2013.

[26] V. Ignatiev, A. Surenkov, S. Abalin, I. Gnidoi, A. Kulakov, and V. Uglov, Nickel based alloys compatibility with fuel salts for molten salt reactor with thorium and uranium support, Nuclear Science, 2015.

[27] V. Ignatiev, A. Surenkov, I. Gnidoi, V. Fedulov, V. Uglov, V. Afonichkin, A. Bovet, V. Subbotin, A. Panov, and A. Toropov, Compatibility of selected Ni-based alloys in molten Li,Na,Be/F salts with PuF3 and tellurium additions, Nuclear Technology 164(1), 130-42, 2017. 
[28] A.F. Rowcliffe, L.K. Mansur, D.T. Hoelzer, R.K. Nanstad, Perspectives on radiation effects in nickel-base alloys for applications in advanced reactors, J. Nucl. Mater. 392(2), 341-352, 2009.

[29] R.M. Boothby, 4.04 radiation effects in nickel-based alloys, in: R. Konings and T. R. Allen (Eds.), Comprehensive Nuclear Materials, 123-150, 2012.

[30] R.K. Nanstad, D.A. McClintock, D.T. Hoelzer, L. Tan, and T.R. Allen, High temperature irradiation effects in selected Generation IV structural alloys, J. Nucl. Mater. 392(2), 331-340, 2009.

[31] G.H. Broomfield, Irradiation effects in structural alloys for thermal and fast reactors, Philadelphia, 1965, p. 65.

[32] A. Rowcliffe, Effects of Radiation on Structural Metals, American Society for Testing and Materials, Philadelphia, 1967, p. 161.

[33] R.D. Nicholson and R.B. Jones, Effects of Radiation on Materials, American Society for Testing and Materials, Philadelphia, 1979, p. 529.

[34] R. Bajaj in: D. Kramer, H.R. Brager, and J.S. Perrin (Eds.), Effects of Radiation on Materials, American Society for Testing and Materials, Philadelphia, 1981, p. 326.

[35] W.J.S. Yang, D. Gelles, J.L. Straalsund, and R. Bajaj, Post-irradiation ductility loss of Fe-Ni-base precipitation hardenable alloys, J. Nucl. Mater. 132, 249-265, 1985.

[36] R.M. Boothby and D.R. Harries, Mechanical behavior and nuclear applications of stainless steel at elevated temperatures, Metals Society, London, 1982.

[37] R.M. Boothby, The microstructure of fast neutron irradiated Nimonic PE16, J. Nucl. Mater. 230, 148-157, 1996.

[38] W.K. Appleby, D.W. Sandusky, and U.E. Wolff, Swelling resistance of a high nickel alloy, J. Nucl. Mater. 43, 213-218, 1972.

[39] J. Gan, J.I. Cole, T.R. Allen, S. Shutthanandan, and S. Thevuthasan, Irradiated microstructure of alloy 800H, J. Nucl. Mater. 351(1-3), 223-227, 2006.

[40] L. Tan, K. Sridharan, T.R. Allen, R.K. Nanstad, and D.A. McClintock, Microstructure tailoring for property improvements by grain boundary engineering, J. Nucl. Mater. 374(1-2), 270-280, 2008.

[41] L. Tan, J.T. Busby, H.J. MacLean Chichester, K. Sridharan, and T.R. Allen, Microstructural effect on neutron irradiation response of alloy $800 \mathrm{H}$, Transactions of the American Nuclear Society 106, 1331-1332, 2012.

[42] L. Tan, L. Rakotojaona, T.R. Allen, R.K. Nanstad, and J.T. Busby, Microstructure optimization of austenitic Alloy $800 \mathrm{H}(\mathrm{Fe}-21 \mathrm{Cr}-32 \mathrm{Ni})$, Materials Science and Engineering: A 528(6), 2755-2761, 2011.

[43] L. Tan, T.R. Allen, and J.T. Busby, Grain boundary engineering for structure materials of nuclear reactors, J. Nucl. Mater. 441(1-3), 661-666, 2013.

[44] Y. Katoh, D.F. Wilson, and C.W. Forsberg, Assessment of Silicon Carbide Composites for Advanced Salt-cooled Reactors, ORNL/TM-2007/168, Oak Ridge National Laboratory, 2007.

[45] A.A. Campbell, Y. Katoh, M.A. Snead, and K. Takizawa, Property changes of G347A graphite due to neutron irradiation, Carbon 109, 860-873, 2016. 
[46] Y. Katoh, L.L. Snead, I. Szlufarska, and W.J. Weber, Radiation effects in SiC for nuclear structural applications, Current Opinion in Solid State \& Materials Science 16(3), 143-152, 2012.

[47] X. Yang, D. Zhang, M. Liu, S. Feng, W. Xue, H. Liu, G. Yu, X. Zhou, H. Xia, P. Huai, Z. $\mathrm{Li}, \mathrm{Y}$. Lu, H. Zhou, and S. Dong, Corrosion of SiC induced by Hastelloy $\mathrm{N}$ alloy and its corrosion products in LiF-NaF-KF molten salt, Corrosion Science 109, 62-67, 2016.

[48] Y. Katoh, K. Ozawa, C. Shih, T. Nozawa, R.J. Shinavski, A. Hasegawa, and L.L. Snead, Continuous SiC fiber, CVI SiC matrix composites for nuclear applications: Properties and irradiation effects, J. Nucl. Mater. 448(1-3), 448-476, 2014.

[49] Y. Katoh, N. Hashimoto, S. Kondo, L.L. Snead, and A. Kohyama, Microstructural development in cubic silicon carbide during irradiation at elevated temperatures, $\mathrm{J}$. Nucl. Mater. 351(1-3), 228-240, 2006.

[50] Y. Katoh, T. Nozawa, L.L. Snead, K. Ozawa, and H. Tanigawa, Stability of SiC and its composites at high neutron fluence, J. Nucl. Mater. 417(1-3), 400-405, 2011.

[51] T. Koyanagi, T. Nozawa, Y. Katoh, and L.L. Snead, Mechanical property degradation of high crystalline $\mathrm{SiC}$ fiber-reinforced $\mathrm{SiC}$ matrix composite neutron irradiated to $\sim 100$ displacements per atom, Journal of the European Ceramic Society 38(4), 10871094, 2018.

[52] J. Li, H. Huang, Q. Huang, M. Tang, B. Zhao, G. Ji, W. Zhang, R. Xie, and L. Yan, Effect of irradiation damage on corrosion of $4 \mathrm{H}-\mathrm{SiC}$ in FLiNaK molten salt, Corrosion Science 125, 194-197, 2017.

[53] T. Koyanagi, Y. Katoh, K. Ozawa, K. Shimoda, T. Hinoki, and L.L. Snead, Neutronirradiation creep of silicon carbide materials beyond the initial transient, J. Nucl. Mater. 478, 97-111, 2016.

[54] G. Singh, T. Koyanagi, C. Petrie, K. Terrani, Y. Katoh, Evaluating the irradiation effects on the elastic properties of miniature monolithic SiC tubular specimens, J. Nucl. Mater. 499, 107-110, 2018.

[55] S.J. Zinkle, Challenges in developing materials for fusion technology-past, present and future, Fusion Sci. Technol. 64, 65-75, 2013.

[56] J. Stempien. Tritium transport modeling in FHRs, presented at Molten Salt Reactor Workshop, Oak Ridge, TN, October 2017. 


\section{$4 \quad$ ASME CODE QUALIFICATION, SECTION III DIMSION 5}

\subsection{Introduction}

Rules of ASME BPVC Section III Division 5 [1] govern the construction of vessels, storage tanks, piping, pumps, valves, supports, core support structures, and nonmetallic core components for use in high-temperature reactor systems and their supporting systems. "Construction," as used by ASME, is an all-inclusive term that includes material, design, fabrication, installation, examination, testing, overpressure protection, inspection, stamping, and certification. High-temperature reactors covered by Division 5 include gas-cooled reactors, liquid metal reactors, and MSRs with liquid or solid fuel.

Design procedures and materials data not contained in Division 5 may be required to ensure the integrity or the continued functioning of the structural part during the specified service life. For example, Division 5 rules do not provide methods to evaluate deterioration that may occur in service as a result of corrosion, mass transfer phenomena, radiation effects, or other material instabilities (except the effects of thermal aging on yield and ultimate stresses.) It is required by Division 5 that these effects shall be taken into account with a view to realizing the design or the specified life of the components and supports. It is the responsibility of the owner/operator to demonstrate to the US Nuclear Regulatory Commission (NRC) that these effects are accounted for.

The format of Division 5 is shown in Table 22.

Table 22 ASME, Section III, Division 5 format .

\begin{tabular}{|c|c|c|c|c|c|}
\hline Class & $\begin{array}{c}\text { Sub- } \\
\text { section }\end{array}$ & Subpart & $\begin{array}{c}\text { Subsection } \\
\text { ID }\end{array}$ & Title & Scope \\
\hline \multicolumn{6}{|c|}{ General Requirements } \\
\hline Class A, B, \& SM & \multirow[t]{2}{*}{ HA } & A & HAA & Metallic Materials & Metallic \\
\hline Class SN & & $\mathrm{B}$ & HAB & $\begin{array}{l}\text { Graphite and Composite } \\
\text { Materials }\end{array}$ & Nonmetallic \\
\hline \multicolumn{6}{|c|}{ Class A Metallic Pressure Boundary Components } \\
\hline Class A & \multirow[t]{2}{*}{ HB } & $\mathrm{A}$ & HBA & Low Temperature Service & Metallic \\
\hline Class A & & $\mathrm{B}$ & HBB & Elevated Temperature Service & Metallic \\
\hline \multicolumn{6}{|c|}{ Class B Metallic Pressure Boundary Components } \\
\hline Class B & \multirow[t]{2}{*}{$\mathrm{HC}$} & $\mathrm{A}$ & HCA & Low Temperature Service & Metallic \\
\hline Class B & & $\mathrm{B}$ & $\mathrm{HCB}$ & Elevated Temperature Service & Metallic \\
\hline \multicolumn{6}{|c|}{ Class A and Class B Metallic Supports } \\
\hline Class A \& B & $\mathrm{HF}$ & $\mathrm{A}$ & HFA & Low Temperature Service & Metallic \\
\hline \multicolumn{6}{|c|}{ Class SM Metallic Core Support Structures * } \\
\hline Class SM & \multirow[t]{2}{*}{ HG } & $\mathrm{A}$ & HGA & Low Temperature Service & Metallic \\
\hline Class SM & & $\mathrm{B}$ & HGB & Elevated Temperature Service & Metallic \\
\hline \multicolumn{6}{|c|}{ Class SN Nonmetallic Core Components * } \\
\hline Class SN & \multirow[t]{2}{*}{$\mathrm{HH}$} & $\mathrm{A}$ & HHA & Graphite Materials & Graphite \\
\hline Class SN & & $\mathrm{B}$ & HHB & Composite Materials & Composite \\
\hline
\end{tabular}

* Class designations being balloted by ASME 
For low-temperature service, the application and use of the Division 5 rules is identical to that for Division 1 construction, except that Division 5 rules may use different terminology.

Note that Division 5 is a component code, providing construction rules for the component classes shown in Table 22. The classification of reactor components into safety and non-safety classes requires the consideration of the entire reactor system according to American Nuclear Society (ANS) requirements and is outside the scope of Division 5.

\subsection{Subsection HB, Subpart B -Metallic Components}

The current Subsection HB, Subpart B (HBB) criteria and material coverage for Class A metallic components are the culmination of a long process of development initiated approximately five decades ago to support the construction of sodium- and gas-cooled reactors of the era. In the late 1960s, the Atomic Energy Commission initiated a Materials and Structures Technology program and simultaneously asked the ASME B\&PV Code Committee to charge an expanded Subgroup on Elevated Temperature Design with developing the design rules that eventually provided the basis for HBB. This development process has continued with periodic modifications and improvements to the code cases; subsequent subsections; and, currently, Section III, Division 5. As with all ASME code rules, development is an ongoing process.

The purpose of the early code cases for elevated-temperature service was to provide rules for construction that account for the effects of deformation and damage due to creep with the same rigor with which Division 1 addressed low-temperature service in which creep effects are not significant. As in Division 1 Subsection NB, the rules of construction in HBB are based on the design-by-analysis approach. The stresses are categorized into primary, secondary, and peak stresses. However, because of the significant difference in the structural behavior at elevated temperature compared with that at low temperature, HBB has adopted the approach of placing limits on two basic types of controlled quantities: (1) load controlled, and (2) deformation controlled.

The structural failure modes covered by HBB for elevated-temperature service include the time-independent structural failure modes of Division 1 Subsection NB:

(1) Ductile rupture from short-term loading

(2) Gross distortion due to incremental collapse and ratcheting

(3) Loss of function due to excessive deformation

(4) Buckling due to short-term loading and new time-dependent structural failure modes

(5) Creep-rupture from long-term loading

(6) Creep-fatigue failure

(7) Creep-buckling due to long-term loading

Load-controlled quantities are primary stresses. To account for differing loads, times, and temperatures, time-dependent allowable stress is introduced in HBB for time-dependent loads and is based on the time to $1 \%$ total strain, time to start of tertiary creep and creep-rupture strength. These allowable stresses are used to set different primary stress limits for Level A 
(normal), B (upset), C (emergency), and D (faulted) service events, similar to low-temperature service. But time-of-loading is an additional variable that needs to be considered because of the time dependency. The primary stress limits cover structural failure modes (1) and (5) listed above.

The deformation-controlled quantities are stresses, strains, and deformations resulting from load, deflection, and strain compatibility. Acceptable deformation-controlled limits are provided in HBB and cover strain limits/ratcheting, creep-fatigue damage, and buckling and welds. Strain limits and creep-fatigue damage rules can be satisfied using either elastic or inelastic analysis methods. Elastic analysis rules, sometimes referred to as "simplified methods," were originally envisioned as a simpler, more conservative and less costly screening method. Inelastic rules that required inelastic analyses were envisioned as more costly and time consuming, but an adequately conservative "gold standard." Failure modes (2), (3), and (6) listed above are covered by the strain limits and creep-fatigue damage rules of HBB.

In addition to deformation-controlled limits, HBB includes rules for general loading conditions evaluated with inelastic analysis, including the time-dependent effects of creep. Rules to address structural failure modes (4) and (7) for short-term and long-term buckling are also given in HBB.

The load and deformation limits and design evaluation methods developed in HBB to guard against these structural failure modes establish the data requirements and hence the testing needs in qualifying new Class A materials. They also establish the key mechanical properties that need to be assessed because of deterioration that may occur in service as a result of corrosion, mass transfer phenomena, radiation effects, or other material instabilities. The licensee needs to demonstrate to NRC that these effects are accounted for.

There are five qualified Class A base materials in HBB. They are Types 304 and 316 SS, 21/4Cr$1 \mathrm{Mo}$ (solution-annealed) ferritic steel, Grade 91 steel, and Alloy $800 \mathrm{H}$ austenitic alloy. Alloy 617, a Ni-based alloy, is currently being balloted by ASME Code committees for approval as a Class A material. The use of SA-533 Type B, Class 1 plate and SA-508 Grade 3, Class 1 forging is also permitted in HBB for limited elevated temperature service for Class A components.

The permissible weld metals for Class A components are given in Table 23.

Allowable temperature and time for Class A component cannot exceed those values associated with the time-dependent allowable stress, $S_{m t}$, data for the specified material. However, many of the Class A reactor components are welded constructions, and the allowable temperature and time of the permissible weld metal would impact the maximum temperature and time to which a component can operate. Additionally, the highest-temperature fatigue curves that are available would also influence the maximum temperature to which a Class A component can be designed, as creep-fatigue damage is one of the key structural failure modes. These temperature and time restrictions are given in Table 24. 
Table 23 Permissible weld materials for Class A components .

\begin{tabular}{|c|c|c|}
\hline Base materials & $\begin{array}{l}\text { Specification } \\
\text { no. }\end{array}$ & Class \\
\hline \multirow[t]{3}{*}{ Types 304 SS and 316 SS } & SFA-5.4 & E 308, E 308L, E 316, E 316L, E 16-8-2 \\
\hline & SFA-5.9 & $\begin{array}{l}\text { ER 308, ER 308L, ER 316, ER 316L, ER } \\
\text { 16-8-2 }\end{array}$ \\
\hline & SFA-5.22 & $\begin{array}{l}\text { E 308, E 308T, E 308LT, E 316T, E } \\
\text { 316LT-1 E XXXT-G (16-8-2 chemistry) }\end{array}$ \\
\hline \multirow[t]{2}{*}{ Fe-Ni-Cr (Alloy 800H) } & SFA-5.11 & E NiCrFe-2 \\
\hline & SFA-5.14 & ER NiCr-3 \\
\hline \multirow[t]{4}{*}{$2 \frac{1}{4} \mathrm{Cr}-1 \mathrm{Mo}$} & SFA-5.5 & E 90XX-B3 (>0.05\% carbon) \\
\hline & SFA-5.23 & E B 3, E CB 3 \\
\hline & SFA-5.28 & E 90C-B3 (>0.05\% carbon), ER 90S-B3 \\
\hline & SFA-5.29 & E 90T-B3 (>0.05\% carbon) \\
\hline \multirow[t]{3}{*}{ 9Cr-1Mo-V (Grade 91) } & SFA-5.5 & E 90XX-B9 \\
\hline & SFA-5.23 & E B9 \\
\hline & SFA-5.28 & ER 90S-B9 \\
\hline $\begin{array}{l}\text { Ni-Cr-Co-Mo (Alloy 617) } \\
\text { Being balloted by ASME for } \\
\text { approval (completion } \\
\text { expected by August 2020) }\end{array}$ & SFA-5.14 & ER NiCrCoMo-1 \\
\hline $\begin{array}{l}\text { SA-533 Type B, Class } 1 \\
\text { plates SA-508 Grade 3, Class } \\
1 \text { forging (short-term } \\
\text { elevated-temperature } \\
\text { excursions) }\end{array}$ & & Associated weld metals \\
\hline
\end{tabular}


Table 24 Temperature and time limits for HBB design parameters of Class A materials .

\begin{tabular}{|c|c|c|c|c|c|c|}
\hline \multirow{2}{*}{$\begin{array}{c}\text { Base } \\
\text { material }\end{array}$} & \multicolumn{2}{|c|}{$\begin{array}{l}\text { Time-dependent } \\
\text { allowable, Smt, and } \\
\text { rupture stress, Sr }\end{array}$} & \multirow{2}{*}{$\begin{array}{l}\text { Fatigue } \\
\text { curve temp. } \\
\text { range }\left({ }^{\circ} \mathrm{F}\right)\end{array}$} & \multicolumn{3}{|c|}{$\begin{array}{l}\text { Stress rupture factor } \\
\text { for weldment }\end{array}$} \\
\hline & $\begin{array}{c}\text { Temp range } \\
\left({ }^{\circ} \mathrm{F}\right)\end{array}$ & $\begin{array}{c}\text { Time } \\
\text { (h) }\end{array}$ & & Weld & $\begin{array}{c}\text { Temp } \\
\left.\text { range ( }{ }^{\circ} \mathrm{F}\right)\end{array}$ & $\begin{array}{c}\text { Time } \\
\text { (h) }\end{array}$ \\
\hline \multirow[t]{3}{*}{$\begin{array}{l}\text { Type } 304 \\
\text { SS }\end{array}$} & $>800-1500$ & 300,000 & $>800-1300$ & $\begin{array}{l}\text { E 308, E 308L, } \\
\text { ER 308, ER 308L, } \\
\text { E 308, E 308T, } \\
\text { E 308LT }\end{array}$ & $>800-1250$ & 300,000 \\
\hline & & & & $\begin{array}{l}\text { E 316, E 316L, } \\
\text { ER 316, ER 316L, } \\
\text { E 316T, E 316LT-1 }\end{array}$ & $>800-1400$ & 300,000 \\
\hline & & & & $\begin{array}{l}\text { E 16-8-2, ER 16-8-2, } \\
\text { E XXXT-G (16-8-2 } \\
\text { chemistry) }\end{array}$ & $>800-1200$ & 300,000 \\
\hline \multirow[t]{3}{*}{$\begin{array}{l}\text { Type } 316 \\
\text { SS }\end{array}$} & $>800-1500$ & 300,000 & $>800-1300$ & $\begin{array}{l}\text { E 308, E 308L, } \\
\text { ER 308, ER 308L, } \\
\text { E 308, E 308T, } \\
\text { E 308LT }\end{array}$ & $>800-1300$ & 300,000 \\
\hline & & & & $\begin{array}{l}\text { E 316, E 316L, } \\
\text { ER 316, ER 316L, } \\
\text { E 316T, E 316LT-1 }\end{array}$ & $>800-1400$ & 300,000 \\
\hline & & & & $\begin{array}{l}\text { E 16-8-2, ER 16-8-2, } \\
\text { E XXXT-G (16-8-2 } \\
\text { chemistry) }\end{array}$ & $>800-1200$ & 300,000 \\
\hline Alloy $800 \mathrm{H}$ & $>800-1400$ & 300,000 & $>800-1400$ & $\begin{array}{l}\text { E NiCrFe-2, ER NiCr- } \\
3\end{array}$ & $>800-1400$ & 300,000 \\
\hline $2 \frac{1}{4} \mathrm{Cr}-1 \mathrm{Mo}$ & $\begin{array}{l}>700-1100 \\
>1100-1200\end{array}$ & $\begin{array}{l}300,000 \\
1000\end{array}$ & $>700-1000$ & $\begin{array}{l}\text { E 90XX-B3 (>0.05\% } \\
\text { Carbon), E B 3, } \\
\text { E CB 3, E 90C-B3 } \\
\text { (>0.05\% Carbon), } \\
\text { ER 90S-B3, E 90T-B3 } \\
\text { (>0.05\% Carbon) }\end{array}$ & $>700-1200$ & 300,000 \\
\hline Grade 91 & $>700-1200$ & 300,000 & & $\begin{array}{l}\text { E 90XX-B9, E B9, } \\
\text { ER 90S-B9 }\end{array}$ & $>700-1200$ & 300,000 \\
\hline Alloy 617 & $>800-1750$ & 100,000 & $>800-1750$ & ER NiCrCoMo-1 & $>800-1750$ & 100,000 \\
\hline \multirow{3}{*}{$\begin{array}{l}\text { SA-533 } \\
\text { Type B, } \\
\text { Class } 1 \\
\text { plate, SA- } \\
508 \text { Grade } \\
3 \text {, Class } 1 \\
\text { forging }\end{array}$} & $\begin{array}{l}\text { Smt: >700- } \\
800 \text { (Level B) }\end{array}$ & 3,000 & $>700-1000$ & Associated welds & $>700-100$ & \\
\hline & $\begin{array}{l}\text { Smt: }>800- \\
1000 \text { (Level } \\
\text { C or D) }\end{array}$ & 1000 & & & & \\
\hline & $\begin{array}{l}\text { Sr: }>700- \\
1000\end{array}$ & 100,000 & & & & \\
\hline
\end{tabular}


The permissible bolting materials for Class A components are Types 304 SS and 316 SS and Alloy 718. Their specifications are given in Table 25.

Table 25 Specifications and grades of $p$ ermissible bolting materials for Class $\mathrm{A}$ compon ents. [1]

\begin{tabular}{|lll|}
\multicolumn{1}{|c|}{ Material } & \multicolumn{1}{c|}{ Specification no. } & \multicolumn{1}{c|}{ Grades } \\
\hline Type 304 SS & SA-193 & B8, Class 1 and B8A, Class 1A \\
Type 316 SS & SA-193 & B8M, Class 1 and B8MA, Class 1A \\
Ni-Cr-Fe-Mo-Cb (Alloy 718) & SB-637 & NO 7718 \\
\hline
\end{tabular}

A guideline on data requirements for new Class $A$ materials has been introduced in HBB, Appendix HBB-Y, "Guidelines for Design Data Needs for New Materials," of Section III Division 5, [1]. A summary of the HBB-Y paragraphs on data requirements is given in Table 26.

Table 26 HBB-Y paragraphs on data requirements for new Class A material . [1]

\section{Data requirement for new Class A material}

- HBB-Y-2100 Requirement for Timeindependent Data

- $\quad$ HBB-Y-2110 Data Requirement for Tensile Reduction Factors for Aging

- HBB-Y-2200 Requirement for TimeDependent Data

- HBB-Y-2300 Data Requirement for Weldments

- HBB-Y-3100 Data Requirement for Isochronous Stress-Strain Curves

- HBB-Y-3200 Data Requirement for Relaxation Strength

- HBB-Y-3300 Data Requirement for Creep-Fatigue

- HBB-Y-3400 Data Requirement for Creep-Fatigue of Weldments
- HBB-Y-3500 Data Requirement for Cyclic Stress-Strain Curves

- HBB-Y-3600 Data Requirement for Inelastic Constitutive Model

- HBB-Y-3700 Data requirement for Huddleston Multiaxial Failure Criterion

- HBB-Y-3800 Data Requirement for Time-Temperature Limits for External Pressure Charts

- HBB-Y-4100 Data Requirement for Cold Forming Limits

- Validation of Elastic-Perfectly Plastic (EPP) Simplified Design Methods for the New Alloy

As discussed in previous sections, only a limited number of structural materials are qualified in HBB for Class A components in high-temperature reactor applications. However, allowable stress values, $S$, are tabulated for many materials in ASME BPVC Section II, Part D, Tables $1 \mathrm{~A}$ and 1B for Section VIII Division 1, and Tables 5A and 5B for Section VIII Division 2, high-temperature pressure vessel applications.

Though this should be tempered by the fact that the HBB allowable stresses are very different from those used in Section VIII Division 1 and Division 2, which do not consider the component 
lifetime in the design. The measured parameters for Section VIII allowable stresses in the creep range are time to creep rupture and minimum creep rate as a function of stress and temperature. They are extrapolated to $100,000 \mathrm{~h}$ to define the allowable stresses, S, irrespective of the component life.

However, for elevated-temperature, Section III, Division 5, Class A components, the allowable stress values are explicitly time dependent and require measurement of the time to a total strain of $1 \%$, the onset of third-stage creep and, along with time to rupture, a function of stress and temperature. The later parameters, $1 \%$ strain and third-stage creep, are not conventionally included in the data package for Section VIII allowable stresses. Thus, the major problem facing the deployment of the Section VIII materials for Section III Division 5 is that the test durations and recorded parameters for the Section VIII application provide only limited support for their application for Section III, Division 5, Class A nuclear construction with a target design life of $100,000 \mathrm{~h}$ or longer.

Note that the Section VIII rules do not consider creep-fatigue damage, which is the most severe structural failure mode under elevated-temperature cyclic service. Creep-fatigue is explicitly accounted for in the HBB rules, and fatigue and creep-fatigue data are required to develop limits to support creep-fatigue damage evaluations in HBB.

\subsection{Currently Qualified Class A Materials}

The current Class A materials permitted in HBB are limited and may not be considered optimum for corrosion resistance with respect to molten salts, with or without the dissolved fuel, for MSRs. The Cr contents of Types 304 SS and 316 SS, Alloy $800 \mathrm{H}$, and Alloy 617 are all higher than the preferred 6 to $7 \mathrm{wt} \%$ range for fluoride-based salts. However, by lowering the core outlet temperature, by using replaceable components to shorten the component lifetime, and by introducing a redox control strategy, many MSR developers are able to select Type 316 SS (nominal $16 \mathrm{wt} \% \mathrm{Cr}$ ) as the construction material so that they can deploy their first-of-a-kind MSR systems at the earliest possible time-a first-to-market strategy.

For MSR designs with core outlet temperatures of 1300 and $1400^{\circ} \mathrm{F}\left(\sim 700\right.$ and $\left.760^{\circ} \mathrm{C}\right)$, all the design information for Type 316 SS is available in HBB, except for those given in Table 27. Type 316 SS weld metals with 308 and 316 chemistry have marginal creep-rupture strengths. They are in the range of 40 to $50 \%$ of the creep-rupture strengths of Type 316 SS base metal, for a 7-year design lifetime. However, the creep-rupture strength of the weld metal with 16-8-2 chemistry almost matches that of the Type 316 SS base metal.

Table 27 Availability of design information at different temperature s. [1]

\begin{tabular}{|c|c|c|c|}
\hline \multirow{2}{*}{ Design information } & \multicolumn{2}{|c|}{ Core outlet temperature } & \multirow{2}{*}{ Remark } \\
\hline & $1300^{\circ} \mathrm{F}$ & $1400^{\circ} \mathrm{F}$ & \\
\hline Fatigue design curve & Available & Not available & \\
\hline SRF $^{*}, 308$ weld chemistry & Available & Not available & Low creep-rupture strength \\
\hline SRF, 316 weld chemistry & Available & Available & Low creep-rupture strength \\
\hline SRF, 16-8-2 weld chemistry & $\begin{array}{l}\text { Not } \\
\text { available }\end{array}$ & Not available & $\begin{array}{l}\text { Creep-rupture strength } \\
\text { approaching that of } 316 \mathrm{H}\end{array}$ \\
\hline
\end{tabular}

* SRF = stress rupture factor, for weldment 
To support the use of Type 316 SS as the construction material for MSRs with core outlet temperatures of up to $1400^{\circ} \mathrm{F}\left(760^{\circ} \mathrm{C}\right)$, the design parameters for Type $316 \mathrm{SS}$ in HBB could be optimized by adding a fatigue design curve at $1400^{\circ} \mathrm{F}$ and extending the SRFs for the 16-8-2 weld metal to $1400^{\circ} \mathrm{F}$ and $100,000 \mathrm{~h}$.

\subsection{Development of New Advanced Materials}

A recent review of the status of metallic structural materials for MSRs was given in Wright and Sham [2]. It was concluded that material challenges for MSRs, ranked in order of importance, are irradiation effects, corrosion, and elevated temperature strength. There are a number of advantages in the use of Hastelloy N for MSRs. As discussed in the previous sections, Hastelloy $\mathrm{N}$ was demonstrated as a construction material in the MSRE. There is commercial experience with its production and fabrication and there is an extensive database of creep rupture properties. However, its use is limited to a temperature of about $700^{\circ} \mathrm{C}$ for structural applications because of the low strength at high temperatures. It is also susceptible to tellurium embrittlement and has poor oxidation resistance. Finally, it was concluded that factors limiting the use of Hastelloy $\mathrm{N}$ in MSRs are helium embrittlement and tellurium embrittlement if redox chemistry is not well controlled. Thus, for components in the primary loop of an MSR, the additional effort required to qualify Hastelloy $\mathrm{N}$ as a Class A material in the ASME BPVC was not recommended [2]. For components in the secondary loop-e.g., Class B components, in which neutron irradiation and fission products (tellurium sources) are absent-Hastelloy $\mathrm{N}$ is a good candidate for component construction. The incorporation of Hastelloy $\mathrm{N}$ as a Class $\mathrm{B}$ material in Section III, Division 5 of the ASME BPVC is recommended. The effort required is not significant, as the prerequisite database for Class B qualification is available.

For the long term, it is necessary to develop new metallic alloy(s) that can be used in the welded construction of structural components of thermal or fast spectrum MSR designs using solid or liquid fuel. Characteristics of the new metallic alloy(s) to be considered include, but are not limited to, high-temperature strength, compatibility with fuel and coolant salts, irradiation damage resistance, fission product embrittlement, and weldability - all for the desired lifetimes of the components. The ultimate goal for the alloys developed under such an effort would be their qualification for nuclear service under ASME BPVC Section III, Division 5; hence the long-term stability, fabricability, and potential capability for commercialization of any alloys developed are important.

Such development efforts could focus on current state-of-the-art alloy design approaches, including the use of integrated computational materials engineering, as well as consideration of nontraditional alloys such as high-entropy alloys and additive manufacturing processes. However, it should be understood that this would be a long-term development effort.

\section{Cladded Components}

To support the nth-of-a-kind deployment of MSRs, one can consider increasing the lifetimes of MSR replaceable components constructed of current Class A material by using corrosion-resistant material(s) to clad the salt wetting surfaces. Such a strategy could possibly allow the replaceable components deployed in a first-of-a-kind MSR to last for the entire life of the reactor system, so that replacement is no longer required in the nth-of-a-kind insertion.

The cladded component concept is not new. Stainless steel cladding is used in reactor pressure vessels of LWRs constructed of low-alloy steel for corrosion mitigation. Similarly, the gas and oil 
industry employs cladding materials for high-temperature pressure vessels. Examples of cladded components fabricated from different processes are shown in Figure 43 and Figure 44. The metallurgy of explosively bonded component is shown in Figure 45.

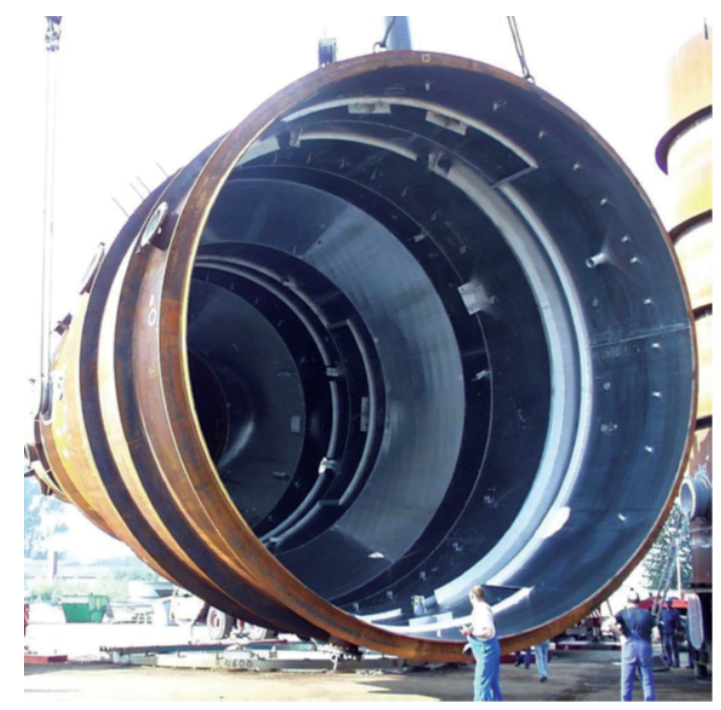

Figure 43 Vessel made from roll -bonded $\mathrm{Ni}$-clad steel; photo from Verbundmetalle $\mathrm{GmbH}$.

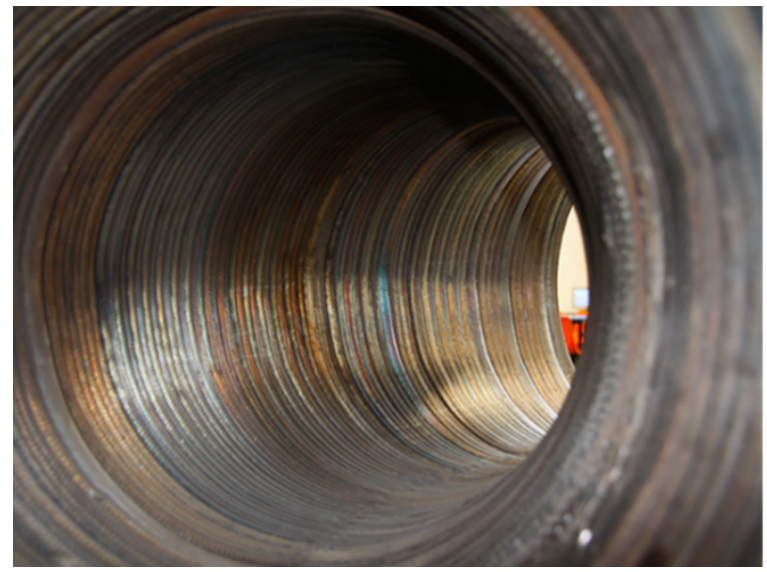

Figure 44 Weld overlay pipe fitting ; image from Chongqing GLEN Flange Limited. 


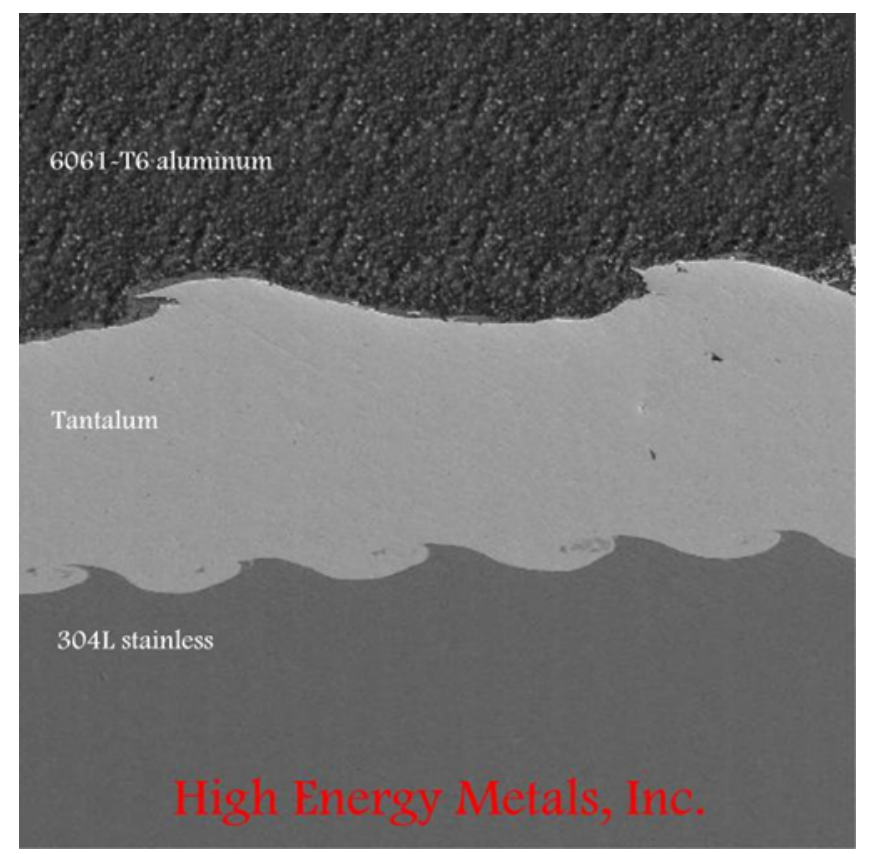

Figure 45 Explosion bonding of aluminum and stainless steel with tantalum interlayer ; photo from High Energy Metals.

Rules for the design and construction of cladded components are provided in ASME BPVC Section VIII for non-nuclear pressure vessel applications. ASTM specifications have been developed for cladded plates, to support these non-nuclear applications [3, 4]. The service experience of cladded non-nuclear pressure vessels is quite extensive. However, the operating conditions and service environments of MSR systems are more severe, placing added demands on the structural integrity of the construction materials. Hence, design practice and service experience for cladded components from non-nuclear industries can be leveraged, but they need to be expanded for elevated-temperature nuclear service.

Further, the licensing process and structural integrity validation for nuclear components is significantly more rigorous and thorough than that for non-nuclear applications. The rules for LWR applications for service temperatures below the creep regime have some guidance for cladding, primarily for thicker cladding that is more than $10 \%$ of the total wall thickness of the component. Below that thickness, there are no material limitations and cyclic evaluation is not required. There is no credit for the cladding for primary, sustained loading at any thickness.

The current Section III Division 5 HBB rules in [1] for cladded structural components in elevatedtemperature service have been assessed by the ASME Code Committees (Working Group on High Temperature Liquid Reactors and Subgroup on Elevated Temperature Design) as deficient in several areas. Most notably, Division 5, Paragraph HBB-3227.8(d), requires that the cladding shall be considered in calculations related to limitations on deformation-controlled quantities, i.e. cyclic loading; however, it does not provide guidance or requirements for that assessment. Thus, applicable design rules will need to be developed to support the design and construction of these cladded components for MSR applications.

The following are R\&D tasks required to support the development of Division 5 HBB construction rules for cladded components in support of the MSR applications: 
1. Review current non-nuclear industry practice on cladded components

2. Understand mechanical interactions between cladding and base metal

3. Understand metallurgical interactions between cladding and base metal

4. Evaluate mechanical integrity of prototype cladding and base metal system

5. Develop cladding material selection guidelines

6. Develop acceptance testing and criteria for the cladding material and composite system

7. Develop and validate design rules and analysis methods

8. Understand corrosion and radiation resistance

9. Evaluate fabrication technologies for cladded component

10. Review post-construction examination and in-service inspection technology

Progress has been made on understanding the mechanical interaction between cladding and base metal. Messner et al. [5] have established a path toward establishing the technical basis for the design of cladded components without long-term test data for the clad material in two types of cladded systems: compliant clads and elastic clads. These strategies are based on a limiting analysis-the compliant clad is treated as infinitely creep-compliant; the elastic clad is analyzed as if it is linearly elastic [5]. Both of these design methods are aimed at avoiding the requirement for an expensive, lengthy creep testing program for each new clad material. Instead, the limiting design methods require only elastic, plastic, and fatigue properties, which should greatly accelerate the adoption of cladded components for high-temperature nuclear service. Further development of the design methods and their experimental validation is continuing.

With the development of design rules, design analysis methods, testing requirements, acceptance criteria, and fabrication and examination procedures as listed above, the ultimate objective is that an MSR developer can select any cladding material, including non-Code qualified material, that is suitable for a specific salt chemistry. The MSR developer would generate necessary data for the cladding material, without long-term testing, to support design and analysis, and would conduct procedure qualification of cladding processes, acceptance testing of the cladded system, component fabrication, and post-construction examination to support cladded component construction and nuclear Code stamping.

\subsection{In Situ, Passive Materials Surveillance Program for MSRs}

The technology maturity for MSR systems is substantially less than for other advanced nonLWRs, such as high-temperature gas-cooled reactors and sodium fast reactors. Information on material degradation due to irradiation, corrosion, elevated-temperature exposure, and creepfatigue loading during MSR operation is limited, as operating experience for MSRs in the United States was mainly from the MSRE at ORNL. An in situ, passive materials surveillance program that would allow the collection of information on these material degradations would be very valuable. 
Data from such materials surveillance programs could be used in a number of ways. A test program using surveillance test articles in a test reactor could be used to evaluate the performance and validate the design basis of existing or new materials for deployment in advanced non-LWRs. Additionally, appropriately designed surveillance test articles could be placed in an operating reactor plant at different key locations to accumulate in situ degradation of material properties - either as the result of prototypical reactor operating conditions or under accelerated stressing conditions engineered into the surveillance test articles. For the former, the surveillance test articles would serve as "canaries" - if surveillance test articles should fail prematurely at preset intervals, that would indicate a potential problem with the structural design, and corrective actions to down-rate the reactor could be implemented. These data, together with data from accelerated stressing conditions, could be used to support power uprates and life extensions.

The need for the use of surveillance test articles was recognized very early on. It was also identified in an ASME Code development roadmap for high-temperature gas-cooled reactors developed in $[6,7]$ for the NRC.

In situ creep testing capabilities have been demonstrated at test reactors, e.g., at the ATR [8] and the Halden research reactor in Norway [9]. The Halden reactor is particularly notable, as it was designed with a system of hydraulic "rabbits" that can deliver and recover a test rig from a particular location in the reactor, with the goal of accumulating exposure time at known reactor environmental conditions. However, these kinds of tests are not suitable for application to an MSR. Specimens designed for use in test reactors typically use active loading by bellows or other mechanical devices and require active control and monitoring of the specimens through cables penetrating the reactor coolant boundary.

There is a well-established precedent for in situ surveillance programs in the current fleet of commercial LWRs. One example is the surveillance specimens in pressurized water reactors designed to guard against embrittlement of the reactor vessel steel. These specimens are periodically removed and tested to determine the current ductile-to-brittle transition temperature of the pressure vessel. Plant operating conditions can be adjusted to maintain an adequate safety margin based on the test data. However, structural materials in LWRs are not exposed to high temperatures in excess of $1,100^{\circ} \mathrm{F}\left(\sim 600^{\circ} \mathrm{C}\right)$ or aggressive, corrosive coolants. Thus, the existing surveillance programs are not suitable for MSRs. To increase the fidelity of the test to actual operating conditions, these specimens will also need to be subject to creep-fatigue loading during exposure. There has been little progress in developing an in situ, passive surveillance test article that can accumulate degradation due to irradiation dose, elevated temperature, aggressive corrosion environment, and creep-fatigue damage simultaneously.

In a recent work, [10], progress was reported on the initial development of an in situ, passive surveillance test article that would simulate the structural follow-up behavior and provide an adequate creep-fatigue strain range in the test section of the test article. Further development to establish an in situ, passive materials surveillance program-including acceptance criteria based on data from the surveillance test article-is necessary to support the use of existing Class $A$ materials, or new materials, in MSRs.

\subsection{Recommendations}

Gaps, and suggested recommendations, have been identified for the following areas. 
To support license applications of first-of-a-kind MSR systems with replaceable structural components of limited design lives, using Section III Division 5 Class A materials, e.g., 316H SS, confirmatory testing of corrosion rates for both fluoride-based and chloride-based salts is recommended. The literature data on salt compatibility are mainly available for $316 \mathrm{~L}$, which has a lower carbon content and lower strength than $316 \mathrm{H}$.

To support first-of-a-kind designs that have core outlet temperatures of up to $1400^{\circ} \mathrm{F}\left(760^{\circ} \mathrm{C}\right)$, it is recommended that the design parameters for Type 316 SS be optimized by adding a fatigue design curve at $1400^{\circ} \mathrm{F}$ and extending the stress rupture factors for the 16-8-2 weld metal to $1400^{\circ} \mathrm{F}$ and $100,000 \mathrm{~h}$.

To support the extension of the lifetimes of replaceable components of first-of-a kind MSR designs, development and validation of ASME Section III Division 5 design rules for Class A components cladded with corrosion resistance materials is recommended.

For the deployment of structural components that are constructed with existing Class A materials, either cladded or uncladded, or with new materials that are more resistant to salts and neutron irradiation under elevated-temperature cyclic service, the development of a materials surveillance program based on the use of in situ, passive surveillance test articles that can be subjected to all of these synergistic effects is important.

\subsection{References}

[1] ASME Boiler and Pressure Vessel Code, Section III Rules for Construction of Nuclear Facility Components, Division 5, High Temperature Reactors, American Society of Mechanical Engineers, New York, July 2017.

[2] R.N. Wright and T.-L. Sham, Status of Metallic Structural Materials for Molten Salt Reactors, INL/EXT-18-45171, Idaho National Laboratory, Idaho Falls, ID, 2018.

[3] ASTM Standard B898-11, Standard Specification for Reactive and Refractory Metal Clad Plate, ASTM International, West Conshohocken, PA, 2011.

[4] ASTM Standard A265-12, Standard Specification for Nickel and Nickel-Base AlloyClad Steel Plate, ASTM International, West Conshohocken, PA, 2012.

[5] M.C. Messner, V.-T. Phan, R.I. Jetter, T.-L. Sham, The mechanical interaction of clad and base metal for molten salt reactor structural components, PVP2018-84101, Proceedings of the ASME 2018 Pressure Vessels and Piping Division Conference, Prague, Czech Republic, American Society of Mechanical Engineers, New York, 2018.

[6] R. Sims, ASME HTGR Code Development Roadmap, STP-NU-045, American Society of Mechanical Engineers, New York, 2010.

[7] R. Sims and J. Nestell, Roadmap to Develop ASME Code Rules For the Construction of High Temperature Gas-Cooled Reactors (HTGRS), STP-NU-045-1, American Society of Mechanical Engineers, New York, June 30, 2012.

[8] B.G. Kim, J.L. Rempe, D.L. Knudson, K.G. Condie, and B.H. Sencer, In-situ creep testing capability for the Advanced Test Reactor, Nuclear Technology, 179(3), pp. 417-428, 2012.

[9] R.W. Kozar, A.W. Jaworski, T.W. Webb and R.W. Smith, In situ monitored in-pile creep testing of zirconium alloys, Journal of Nuclear Materials, 444(1-3), pp. 14-22, 2014. 
[10] M.C. Messner, V.-T. Phan, R.I. Jetter, and T.-L. Sham, Assessment of passively actuated in-situ cyclic surveillance test specimens for advanced non-light water reactors, PVP2018-84793, Proceedings of the ASME 2018 Pressure Vessels and Piping Division Conference, Prague, Czech Republic, American Society of Mechanical Engineers, New York, 2018. 


\section{SYNERGIES WITH OTHERPROGRAMS}

$\mathrm{SiC}$ is being investigated for several other nuclear applications. There is overlap in the physical, mechanical, and microstructural properties being measured for other programs that would be relevant for MSRs. Unique considerations for MSRs that are not being researched for other programs include compatibility with molten salt and gas permeability. Radiation damage of SiC and $\mathrm{SiC} / \mathrm{SiC}$ composites have been extensively studied for advanced fission as fusion concepts, as discussed in section 3.6.

Several large irradiation campaigns have been conducted on various grades of graphite to qualify them for other nuclear applications. There is overlap in the physical, mechanical, and microstructural properties being measured for other programs that would be relevant for MSRs. Note that graphite types are unique, so if a different manufacturer or fabrication process is used for a type of graphite intended for an MSR application, that exact type of graphite would need to be irradiated and tested. Unique considerations for MSRs that are not being researched for other programs include infiltration of salt into the graphite matrix, as discussed in section 2.5 , and the gas permeability of the specific graphite to be used for an MSR.

Many different Ni-based alloys are considered for various Gen IV reactor applications. While salt compatibility is a concern unique to MSRs, issues such as high temperature strength and radiation damage have been extensively researched for other advanced reactor applications, as discussed in chapters 1 and 3 , respectively. There is a common need for full testing and qualification of many potential nuclear applications for one or more Ni-based alloys; but it is unclear if any large effort in this area is currently under way.

Several alloys based on Hastelloy $\mathrm{N}$ have been investigated in corrosion and irradiation testing by the Kurchatov Institute in Russia. Some corrosion and Te-induced cracking data is publicly available, as mentioned in chapter 2 , but it is likely that more data exists which is not yet public. 



\section{CONCLUSIONS AND RECOMMENDATIONS}

Based on the analyses in this document, the following priority knowledge gaps are identified:

1. Code qualification of structural alloys. Several modern alloys, including modified Hastelloy$\mathrm{N}$ variants, may be suitable structural materials; but ASME boiler code qualification is required for use in MSRs, as discussed in chapter 4. This is a very challenging task because of the time and expense required for ASME code qualification, requiring years of creep testing to fully qualify alloys for high-temperature service.

2. Incomplete corrosion data. As discussed in chapter 2, studies of molten salt corrosion have used varied conditions, salt chemistries, and experimental methods, leading to difficulty comparing results across different efforts (see Figure 26). Standards for salt purity are required, along with generally accepted best practices for corrosion testing in molten salts. Reliable data on molten fluorides from the 1960s-1970s exist, but they cover a limited range of salts and alloys and often lack complete salt chemistry analysis. Reliable data for chloride salts are particularly lacking.

3. Incomplete irradiation data. For many of the materials under consideration, there are most commonly data for one type of property (e.g., creep) tested at one or two temperatures and one or two neutron fluences using other fission reactors that do not have the same neutron energy spectrum as an MSR. Alloys in consideration for MSRs would need to be irradiated at several temperatures and fluences and then tested for a variety of thermal and mechanical properties so that a design could be developed with less risk. Also, gas (fission products and $\mathrm{T}$ ) interactions with the metals need to be measured and possibly mitigated. A more complete discussion of the current state of irradiation data is found in chapter 3.

4. Modeling and targeted experimentation to understand degradation fundamentals. Materials behavior in MSRs is not well understood on a fundamental level. Many of the considered alloys are quite complicated and need to be examined with today's advanced experimental and modeling capabilities to investigate the roles of carbide formation, irradiation-induced precipitation, grain boundary segregation, corrosion, He transport, phase changes, thermal aging, transmutation, and other factors. More complete understanding will make it possible to more accurately predict component lifetimes and, if needed, target a strategy to improve these materials' resistance to degradation by combined effects, including corrosion and radiation damage.

5. Limitations of older data sets. Although the MSRE project generated much useful data, it does not represent a large database for one precise alloy. The project's structural material, Hastelloy $\mathrm{N}$, was undergoing active development during the project; so numerous variables were changed over the course of the irradiations including the alloy composition, fabrication method, and heat treatments. Additionally, only the tensile and thermal creep of irradiated materials were measured. Because the imaging capability at the time was limited, the researchers often could not directly observe the microstructural features that dominated the material behavior. There is a need to repeat some of the irradiation work on Hastelloy $\mathrm{N}$ using current microscopy and analysis techniques and measuring a wider range of thermal, physical, and mechanical properties. 
6. Modified Hastelloy $\mathrm{N}$ variants. The original Hastelloy $\mathrm{N}$ composition was determined by the MSRE project to be unsuitable for MSR use because of its irradiation embrittlement. The Hastelloy $\mathrm{N}$ family of alloys are generally regarded as the leading candidates for MSRs; but this category actually contains numerous specific alloy compositions, each with a varying degree of data and unique limitations. For certain salt chemistry, Hastelloy $N$ modified with $\mathrm{Nb}$ was the frontrunner. But if it or any of the other variants were to be used in a reactor, it would require further optimization. Improvements could include the addition of minor alloying elements for improved mechanical properties and irradiation resistance.

7. Incomplete data on moderator behavior. Specific issues are identified for both $\mathrm{SiC}$ and graphite that need further investigation to determine their suitability for use in an MSR. These include creep strength, swelling, thermal conductivity, fluorination, and gas permeation. 


\section{APPENDIX A - ADVANCED HIGH-TEMPERATURE REACTOR}

The advanced high-temperature reactor (AHTR) concept represents the most mature fluoride salt-cooled high-temperature reactor $(F H R)$ design available [1, 2]. It is a central station type FHR with a large thermal output of $3,400 \mathrm{MWth}$; the primary coolant outlet temperature is $700^{\circ} \mathrm{C}$, and the coolant return temperature is $650^{\circ} \mathrm{C}$. The primary and intermediate coolants are $\mathrm{LiF}_{-} \mathrm{BeF}_{2}$ and $\mathrm{KF}-\mathrm{ZrF}_{4}$, respectively. The fuel type is known as tri-structural isotropic particle in carbon plates. The main systems, structures and components (SSCs) that involve structural metallic materials are the reactor vessel and primary piping, guard vessel, primary-to-intermediate heat exchanger $(P-I H X)$, direct reactor auxiliary cooling system (DRACS) HX (DHX), pump, intermediate loop piping, and intermediate to power cycle HX (I-PHX) or steam generator. A brief description of each system is given below so that the working conditions of structural materials can be better understood. The AHTR is used as a model reactor, as it has been studied and a conceptual design is available. The liquid fuel MSR may have additional material requirements, including molten salt compatibility and irradiation resistance, but these can be addressed in other parts of the project.

\section{A.1 Reactor Vessel}

The reactor vessel will be the containment for the molten salts and core internals. It will work at $650^{\circ} \mathrm{C}$, the temperature of the primary coolant return flow. The construction materials for the reactor vessel need to be compatible with molten salts. The primary loads during normal operation will be mainly the hydrostatic load of the vessel contents. Additionally, the large reactor vessel must be strong enough to accommodate seismic loads. The core's thick neutron reflector and the large downcomer are intended to reduce the lifetime neutron fluence to the reactor vessel and prevent it from becoming embrittled.

The reactor vessel is intended to be kept hot for its entire operating life. If the low cycle thermalfatigue properties of the structural alloys are not design limiting, the primary salt temperature could be lowered to $\sim 550^{\circ} \mathrm{C}$ during refueling. The viscosity of the primary coolant would increase undesirably if its freezing point were approached. Hence, all refueling and maintenance operations will need to be performed with the primary coolant at least $550^{\circ} \mathrm{C}$. Thus, the structural alloy could be subjected to a limited number (<200 cycles) of $100 \mathrm{~K}\left(650-550^{\circ} \mathrm{C}\right)$ temperature cycles over its design life.

The AHTR vessel will thus be designed for a service life of at least 60 years. At $650^{\circ} \mathrm{C}$, the creep and creep rupture will dominate the allowable stresses of alloys. The structures need to conform to the 60-year design allowance in Section III-5 of ASME BPVC. However, structural alloys can degrade more rapidly than anticipated as a result of the combined effects of complicated, environment-related, and time-dependent thermomechanical mechanisms. Thus, $60+$ years of service life may not yet be achievable in practice; so the long-term potential for reactor vessel replacement is considered as part of a plant life extension process.

\section{A.2 Primary Loop}

The primary loop piping has similar design constraints as the reactor vessel. As the piping would be somewhat easier to replace than the reactor vessel, it has a higher probability of being fabricated from a new creep-resistant Ni-based alloy. Shorter-term qualification data for a new alloy could be generated to enable its use for a limited term in replaceable components. Alloy testing and qualification would continue while the components are in service, enabling generation 
of longer-term data. The components fabricated from the short-term qualified alloy could then be replaced as necessary, depending on the results of the continuing testing.

\section{A.3 P-IHX}

The $\mathrm{P}-\mathrm{IHX}$ in an FHR is a salt-to-salt HX. The P-IHX serves as part of the radionuclide containment boundary and as such will be constructed in accordance with Section III- 5 of the ASME BPVC. The P-IHX also provides a boundary for the beryllium in the primary coolant and for the dissolved tritium in the primary coolant. The AHTR's primary salt is intended to be FLiBe with highly isotopically separated lithium, and its intermediate salt to be the low-melt point eutectic of KF-ZrF4. The AHTR's baseline design calls for the primary coolant inlet temperature to be $700^{\circ} \mathrm{C}$ and its outlet temperature to be $650^{\circ} \mathrm{C}$ with a flow rate of $9,500 \mathrm{~kg} / \mathrm{s}$ to each of three parallel systems. The outlet temperature of the intermediate coolant will be $675^{\circ} \mathrm{C}$ and its inlet temperature $625^{\circ} \mathrm{C}$. The $\mathrm{P}-\mathrm{IHX}$ is the highest-temperature point in the reactor, where thin components are particularly desirable to improve component performance. Hence, the capabilities of the P-IHX may set the achievable upper temperature of FHRs.

A double-walled tube-and-shell $\mathrm{HX}$ has been selected as the base case for the AHTR. Optimally, the P-IHXs would be designed to last the entire plant life, as they are large structures that will be difficult and expensive to replace. However, acceptable performance is likely possible, provided that the tubing provides multi-decade service. The relationship between operational parameters and service lifetime requires additional investigation, as reactor operations can be shifted to maintain the $\mathrm{HX}$ at normal operating temperatures during outages if creep fatigue is a life-limiting property.

As P-IHX degradation is the temperature-limiting component in FHRs, structural material development should be targeted at HXs. Multi-decade lifetimes are a key requirement for all major power plant components. As testing and qualifying advanced alloys for high-temperature nuclear power plant use requires long-term testing - because of the limited capability to extrapolate materials performance beyond test duration-initiating assessment of the new alloy is a near-term technology development recommendation. Furthermore, a core science need for advanced materials is to develop a validated capability to extend the extrapolation range of alloy performance.

\section{A.4 Intermediate Loop}

The intermediate loop connects the P-IHX with the steam generator (SG). Under normal operating conditions, it transfers hot intermediate salt between the two HXs. The intermediate loop also serves to isolate the nuclear portion of the plant from the electricity generation section. One of the primary issues in providing the isolation is to prevent pressure waves from propagating from the power cycle into the nuclear portion of the plant in case of a major rupture of the I-PHX. The power cycle steam is at substantially greater pressure than the intermediate loop. Without adequate pressure relief, tube failure would cause a pressure wave to propagate back down the intermediate loop with the potential to damage the reactor's radionuclide containment boundary.

The P-IHX forms the outermost credited radionuclide containment layer, and two independent decay heat removal paths, separate from the power cycle, exist in the AHTR design. The design intent is that the intermediate loop not be considered a safety-related item, apart from its rupture disks, and thus be fabricated according ASME B31.1 Power Piping code rules. 


\section{A.5 SG/ I-PHX}

The AHTR's SG is the only location where substantial pressure differences exist in the AHTR design. The pressure in the secondary loop of the I-PHX can be $35 \mathrm{MPa}$ for an ultra-supercritical water power cycle and $30 \mathrm{MPa}$ for a supercritical $\mathrm{CO}_{2}$ power cycle.

The baseline design for the AHTR SG is a counterflow, once-through, tube-and-shell configuration. With a $700^{\circ} \mathrm{C}$ core outlet temperature and allowing for a $25^{\circ} \mathrm{C}$ temperature loss at the P-IHX, the AHTR's SG inlet salt temperature will be $675^{\circ} \mathrm{C}$, which is $\sim 54^{\circ} \mathrm{C}$ hotter than the existing molten salt breeder reactor (MSBR's) SG design [3].

The MSBR SG was designed under Sect. III design rules to provide decay heat removal under some accident conditions. The AHTR's design intent is not to rely on the normal heat rejection path for any safety-related actions or properties. Further, the failure of the SG is designed not to impact the performance of any plant nuclear safety function. Thus, the SG would be designed under ASME Sect. I rules for the construction of power boilers. The use of Sect. I instead of Sect. III design rules substantially broadens the potential range of alloys and construction methods that can be used in an FHR's SG. The fossil industry is currently developing alloy combinations for steam conditions of up to $760^{\circ} \mathrm{C}$. Higher output temperatures directly increase the economic performance of FHRs.

\section{A.6 References}

[1] D.E. Holcomb, F.J. Peretz, A.L. Qualls, Advanced High Temperature Reactor Systems and Economic Analysis, Oak Ridge National Laboratory, ORNL-TM-2011-364, (2011).

[2] V.K. Varma, D.E. Holcomb, F.J. Peretz, E.C. Bradley, D. Ilas, A.L. Qualls, N.M. Zaharia, , AHTR Mechanical, Structural, and Neutronic Preconceptual Design, Oak Ridge National Laboratory, ORNL-TM-2012-320, (2012).

[3] Foster Wheeler Corporation, Task1-Final Report, Design Studies of Steam Generators for Molten-Salt Reactors, Report ND/74/66, (1974). 
